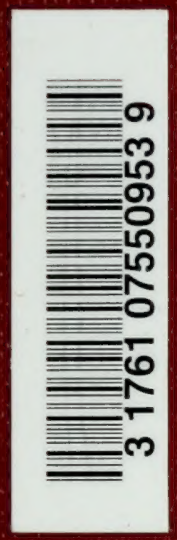





IN WILDEST AFRICA 


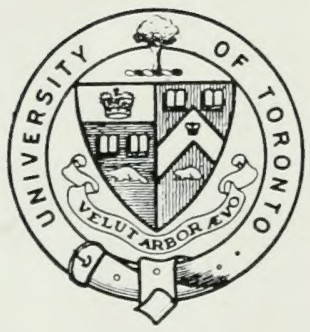

Presented to the

UNIVERSITY OF TORONTO

LIBRARY

by the

ONTARIO LEGISLATIVE

LIBRARY

1980 



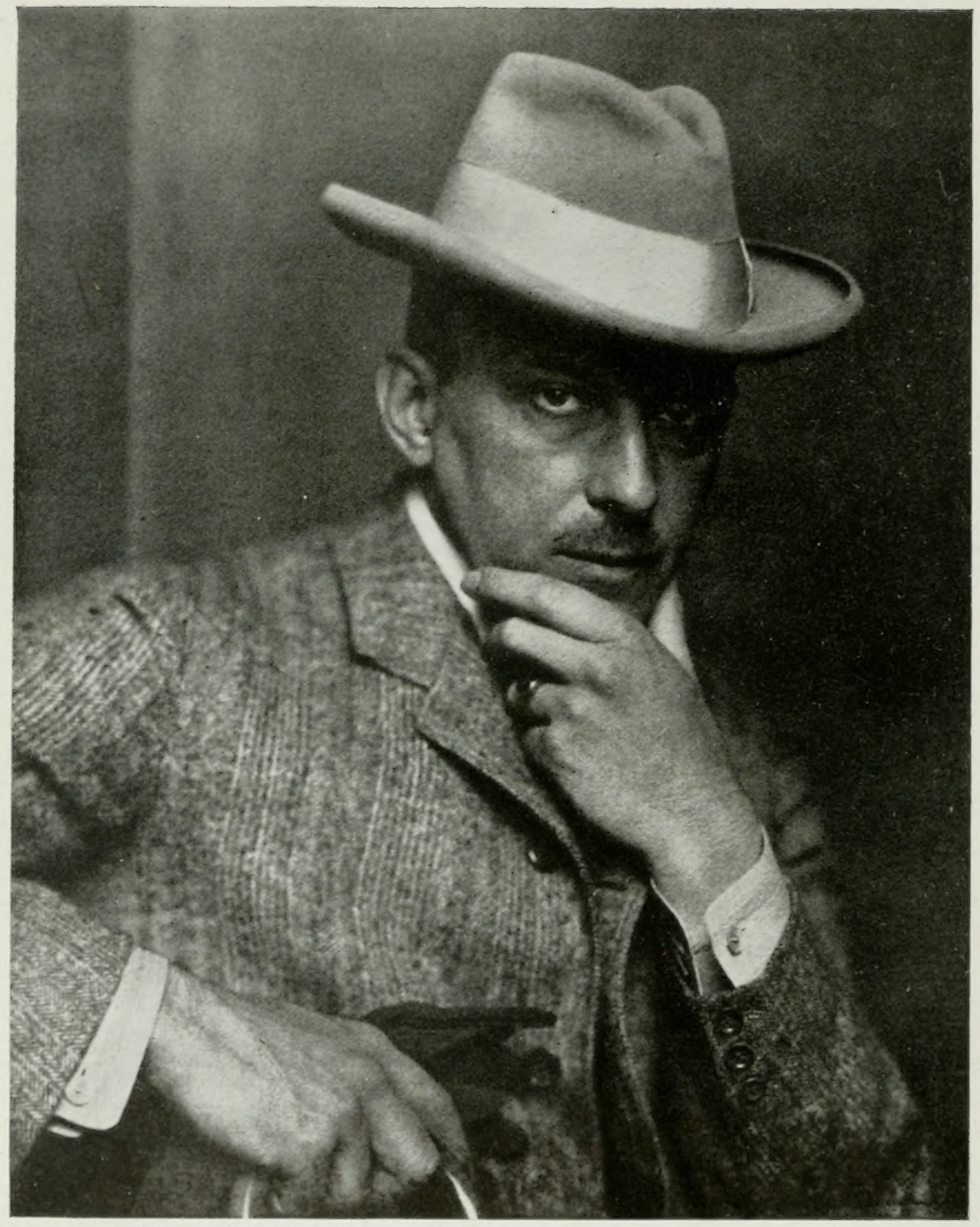

From a Pholograph by Nicola Perscheid, Berlin.

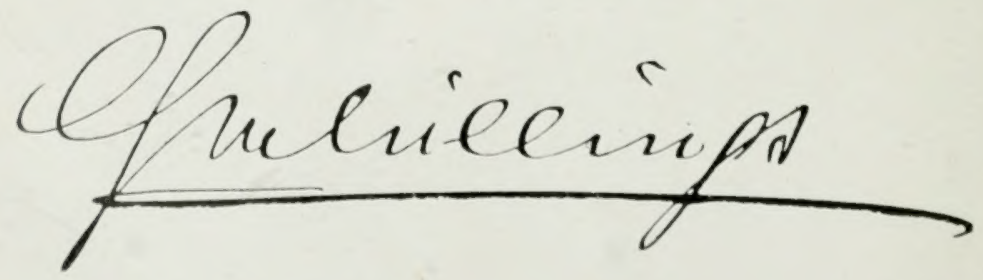




\title{
IN WILDEST AFRICA
}

(1)

\author{
C. G. S.CHILLINGS
}

AUTHOR OF "WITH FLASHLIGHT AND RIFLE IN EQUATORIAL EAST AFRICA"

TRANSLATED BY

FREDERIC WHYTE

WITH OVER 300 PHOTOGRAPHIC STUDIES DIRECT FROM THE AUTHOR'S NEGATIVES, TAKEN BY DAY AND NIGHT; AND OTHER ILLUSTRATIONS

VOL. I

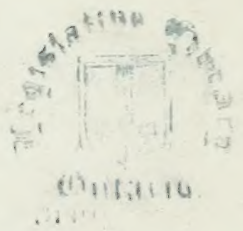

LONDON

HUTCHINSON \& CO.

PATERNOSTER ROW

1907 


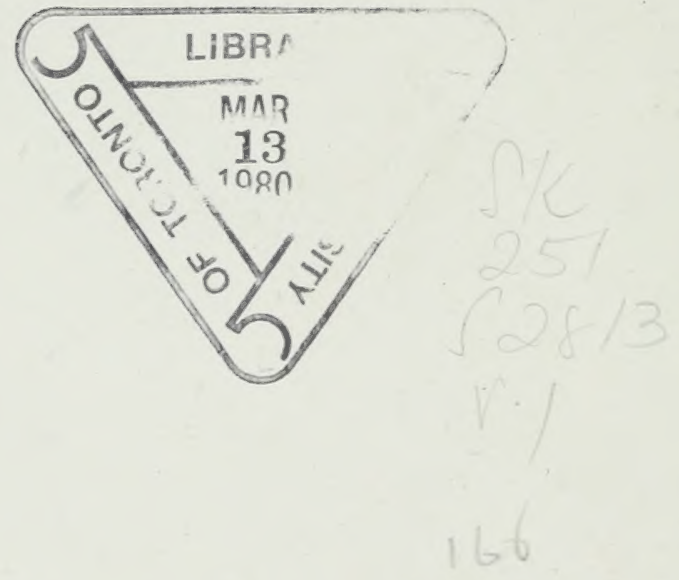




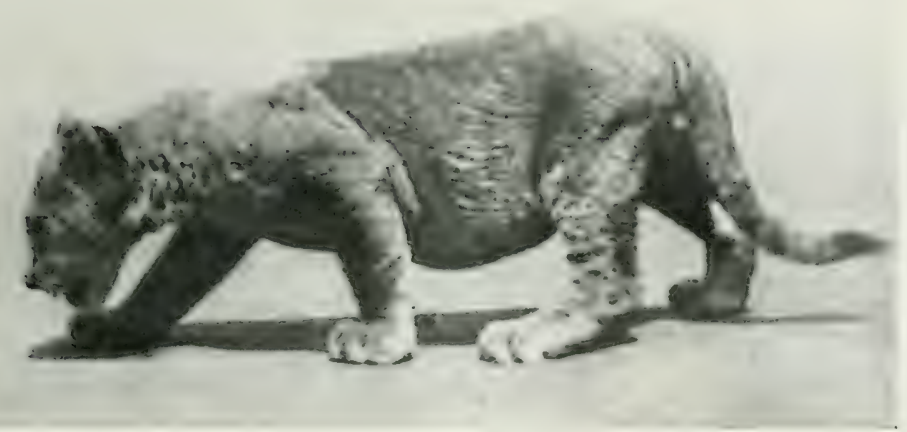

LION STUDY.

\section{Preface}

I NEYER dreamed that my book Irith Flashlight and Rifle - alike in its German and its English and American editions - would receive everywhere so kind a welcome, or that it would make for me so many new friends, both at home and abroad.

I have been encouraged by this success to give a fresh series of my studies of African wild life and of my "Nature Documents," as Dr. Ludwig Heck has designated my photographs, in the present work.

I should like to express my gratitude once again to all those who, in one way or another, have furthered my labours in connection with these two books, especially to Dr. Heck himself and the other men of eminence and learning whose names I mentioned in my preface to II'ith Flashlight and Rifle. A complete list of all my kind helpers and well-wishers would be too long to print here. I am deeply indebted, too, to the many correspondents-- 


\section{Preface}

men of note and young schoolboys alike-who have written to me to express their appreciation of my achievements. Their praises have gone to my heart. I owe a special word of thanks to President Roosevelt, who smoothed the way for my book in the United States by his reference to me in his own volume Outdoor Pastimis of an Amorican Hunter. I take the more pleasure in discharging this debt in that I had long derived intense enjowment from President keosevelt's masterly descrijtions of wild life and sport in America. President Roosevelt has always been one of the foremost pioneers in the movement for the preservation of nature in all its forms, and has made every possible use of the resources placed at his disposal by his high position to further this end.

This new book of mine is in form a series of impressions and sketches, loosely strung together; but it will serve, I hope, indirectly to win over my readers to the one underlying idea-the idea upon which I harp so often -of the importance of taking active steps to prevent the complete extermination of wild life.

Like With Flashlight and Rifle, this supplementary work can claim to stand out from the ranks of all other volumes of the kind as regards the character of its illustrations. All those photographs which I have taken myself are reproduced from the original negatives without retouching of any kind. Every single one, therefore, is an absolutely trustworthy record of a scene visible at a given hour upon the African velt by day or by night. I insist upon this point because herein lie both the value and the fascination of my pictures. 
In his introduction to the English edition of With Flashlight and Rifle Sir Harry Johnston declares that that work was "bound to produce nostalgia in the lines of returned veterans"; I trust that In Wildest Africa will bring also to such readers a breath from the wilderness awaking in them memories of exciting experiences on the velt. Above all, I trust that its appeal will be not to grown readers alone, but that it will have still stronger attractions for the coming generation.

A preface should not be too long. I shall conclude with the expression of the hope that I may be able presently to secure a new collection of "Nature Documents."

$$
\text { C. G. SCHILIINGS. }
$$

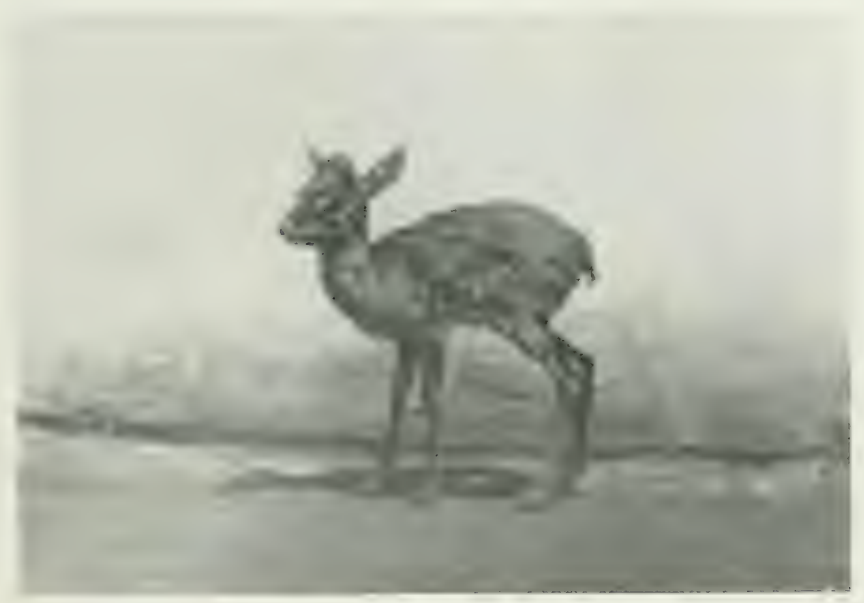

YOUNG DWARF ANTELOPE.

$v i i$

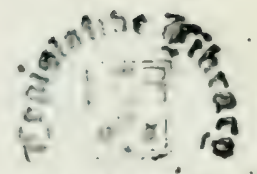





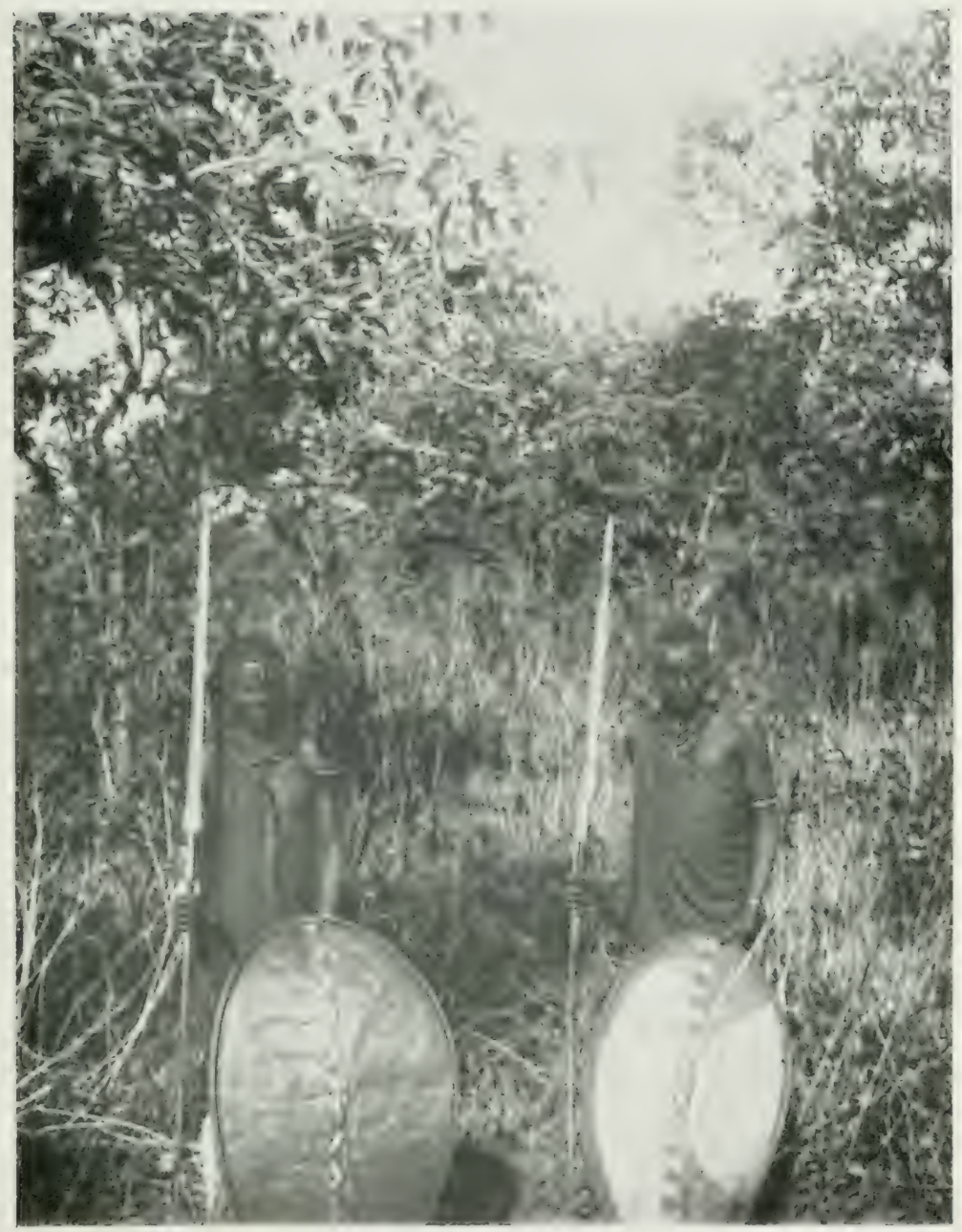

C. G. Schilings, ploot.

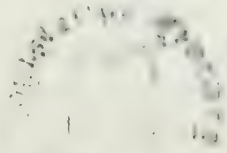





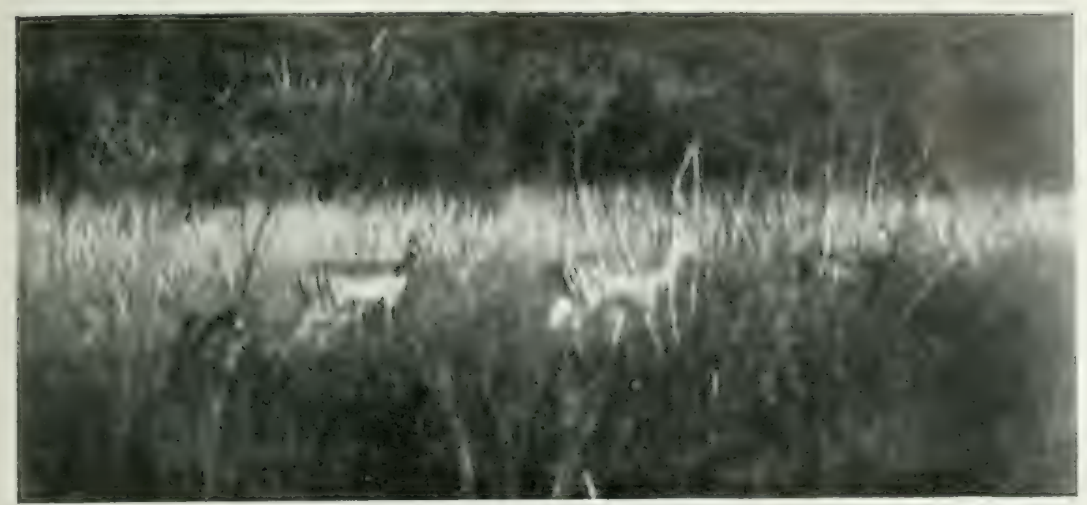

BLACK-HOOFED ANTELOPES.

\section{Contents of Vol. I}

CIIAY.

I. THE SIILL OF TII FLFLESCHO

II. FROM THE CAVE-DWELLER'S SKETCH TO TIIE FLASHLIGHT PHOTOGRAPH . . . . . SS

III. NEIT LIGHT ON THE TRAGEDY OF CIVILISATION • IOF

IV THE SURVIVORS . . . . . . . I 39

I. SHORT AND NATURE IN GERMANY . . . I;9

VI. THE LONELY WONIER-ITORLI) OF THE NIIKA • $2 O+$

VII. THE VOICES OF TIIE WILIERNESS . . . 2S3 



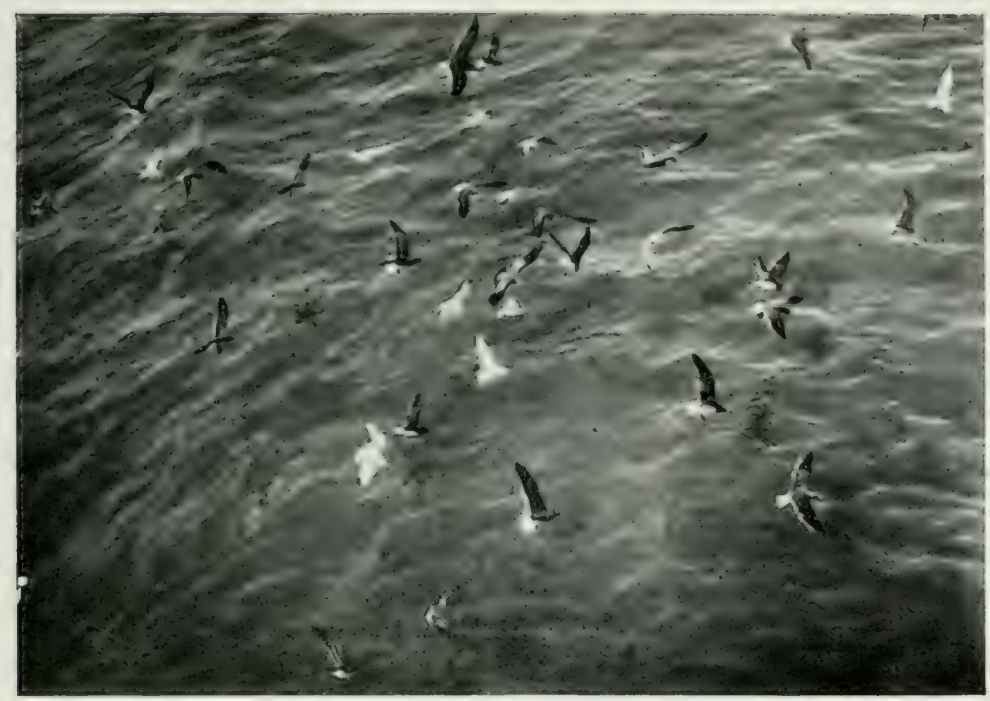

GULLS。

\section{List of Illustrations in Vol. I}

Frontispiece-Portrait of the Author. Lion Study

Young Dwarf Antelope . . . vii

Armed Natives .

Black-hoofed Antelopes . . . xi

Gulls . xiii

A Giraffe Photograph . . . I

My "Boys" organising a "Goma" . 2

Bearers indulging in a Bath . . 3

A Masai ol' moruan (old man) . . 4

Group of Masai . • . . 5

A memento mori of the Velt . . 9

Dwarf Gazelles on the Velt . . II

Masai Herdsmen • . . 13

Young Masai Dancing and Singing . 17

Bearers on the March . . 2I

Transport Bearers in Difficulties o 21

The Author being Carried across a

Swamp . . . .

How Mules and Asses are got across a River.

Two of my Wandorobo Guides facing
A Halt of my Caravan on the Velt . 25

Masai Warriors . . . . . . 29

Group of Masai . . . . . 33

A Party of my trusty Companions . 37

Bearers making their way through high grass . . . . $4^{1}$

The Caravan on the March . . 45

A Herd of Zelras taking Refuge from the Heat of the Midday Sun facing ${ }_{4} S$

Flamingoes on the margin of a Lake . 49

Flamingoes flying down to the Lake margin . . . . 53

Alfred Kaiser in Arab costume . 55

Group of Gnus . . . . $\quad 5^{\mathrm{S}}$

Nile Geese on the Natron Lake . . $5 \mathrm{~S}$

A Herd of Grant's Gazelles . . 59

Crested Cranes and Zebras . . 59

A Camp on the Velt . . . 63

23 Native Settlement on the Pangani River . . . . 67

24 Group of Eland Antelopes . . . $\quad 72$

24 A Herd of White-bearded Gnus. . 73 


\section{List of Illustrations in Vol. I}

A Masai Dance . . . 77

A Ilerd of White-learterl Ginus (i) at close quarters; (ii) a more distant view; (iii) they show their disquict ; (iv) they decicle to retreat facin: So

Effects of Heat and Mirace . . SI

A Ilot Jay in the Great kift Valley . S5

Group of Masai . . . . $S_{7}$

P'rehistoric Sketch on a Fragment of Ivory

Old l'icture of a female Ilippopotamus

An old German Picture of the Giraffe.

IIottentot IIunters: a sketch of two hundred years ago .

Ancient Egyptian representations of Giraffes and other animals

Sketches of Animals made by the Bushmen

Black-tailed Antelopes running through high grass

Bearers on the March

A Rhinoceros moving through velt grass . . . . . 107

Three large Gorillas shot by Captain Dominick

Troop of Lions in broad daylight . I2

IIerd of Elephants in South Africa, ly Harris . . . . I

Group of Wild Animals at IIagenbeck's zoological gardens . . I33

Young Grant's Gazclles . . . 139

'Mrega Monkeys . . . I40

A Mllogra . . facing 142

East $\Lambda$ frican Wild Buffaloes . . 143

Modem Methods of T'axidermy: Setting up a Giraffe . . . 146-149

Male Giraffe Gazelle. . . . 150

I) warf Antelope. . . . . 152

Giraffe Gazelles . . . . 152

Snow-white Black-hooferl Antelope . 153

New Sipecies of llyena

Dwart Musk Deer . . . I5s

A l'air of (jucrezar . . . . 159

Black-hrofed Antelope . . . 164
I'ACE

Giraffe Giazelle and Dwarf Antelope . 165

Hearl of an African Wart-hog . . I68

Nest of Ostrich's Eegrs . . . I69

Drying Ornitholngical specimens . I7t

Group of Author's Trophies • . 175

Women of the Rahe Oasis . . . 177

ligyptian Gecse in a Swamp . . 179

The Nyika: a Mirds-eye View

facing 200

Oryx Antelopes . . . . . 204

A V'elt Ilillock . . . . . 205

The Summit of Mount 'Ngaptuk . 207

A lonk-out Place . . . . 2 II

Black-hoofed Antelopes . . 216, 217

Black-tailed Antelopes . . 222, 223

Masai Ilartebeests . . . . 230

Girafle Gazelle . . . . . 231

Grant's Gazelles . . . facins 234

Grant's Gazelles . . . . . 237

White-bearded Gnus and Zebras taking

Refuge from the Miclday Sun facins 240

An old Acacia . . . . . 244

A typical Landscape . . . . 245

IIungry Vultures . . . . 249

Flamingoes in lilight. . . 252, 253

Storks on the Wing . . . . 258

Storks gathering for Migration . . 259

Remains of Rhinoceroses. . 26I

Crested Cranes in Flight . . . 264

Vultures and Marabous . . . 265

Herd of Waterbuck . . . . . 270

Oryx Intelopes. . . . . . . . . . .

Grant's (iazelles. . . . . . 276

Ilartebeests near the Western 'Niljiri

Swamps . . . . 277

Map of a Day's Movements and Ol)-

servations . . . . 279

Flamingoes on the Margin of the

Natron Lake. . . . . 2i

A Franculin perched on a Thurn-bush as

Flight of Sandfowl . . . . . 257

Yeloras and cinus . firimir 292

An Alaxum-turaco . . . . 295

Nest of Weaver-birds . . . 30r

A Shrike on the Look-out . . . 300

I3rook with an Unclersroumd Chamel 315 


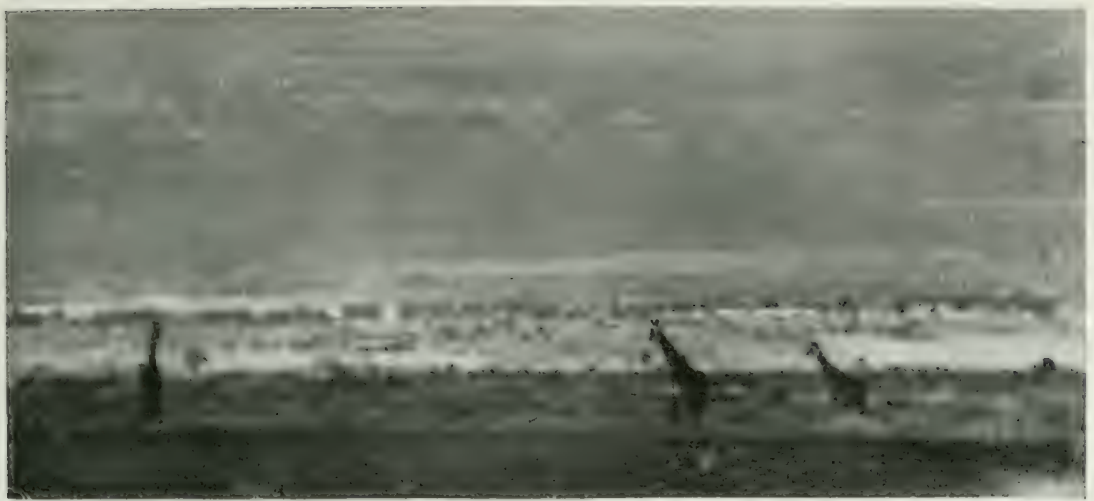

A GIRAFFE PHOTOGRAPH, TAKEN IN THE SHIMAERING LIGHT OF THE VELT.

\section{The Spell of the Elelescho}

( $N$ the afternoon of January 14, isg 7 , a small caravan of native bearers, some fifty strong, was wearily making its way across the wide plain towards its long-wished-for goal, Lake Nakuro, which was at last coming into sight in the far distance. The appearance of the bearers and their worn-out clothing showed plainly that the caravan had made a long journey. And so it was. Weakened by fever, I was coming from he Victoria Nyanza in the hope of making a quicker recovery in this more elevated district. As is the way when one is convalescent, life seemed to me something doubly beautiful and desirable now that, after lying seriously ill for weeks, I was recovering from the fever. I had been all but despaired of by the English officers who had kindly taken care of me, Mr. C. W. Hobley VOL. I 


\section{In Wildest Africa}

and Mr. Tompkins, to whom I owe a debt of gratitude. I had caught the disease in the marshes of the Nyanza and in my tramp through the wild Sotik and Nandi country, then unexplored or very little known. During the last few days our march had once more been imperilled by hostile tribes, the rebel Wakamassia, but

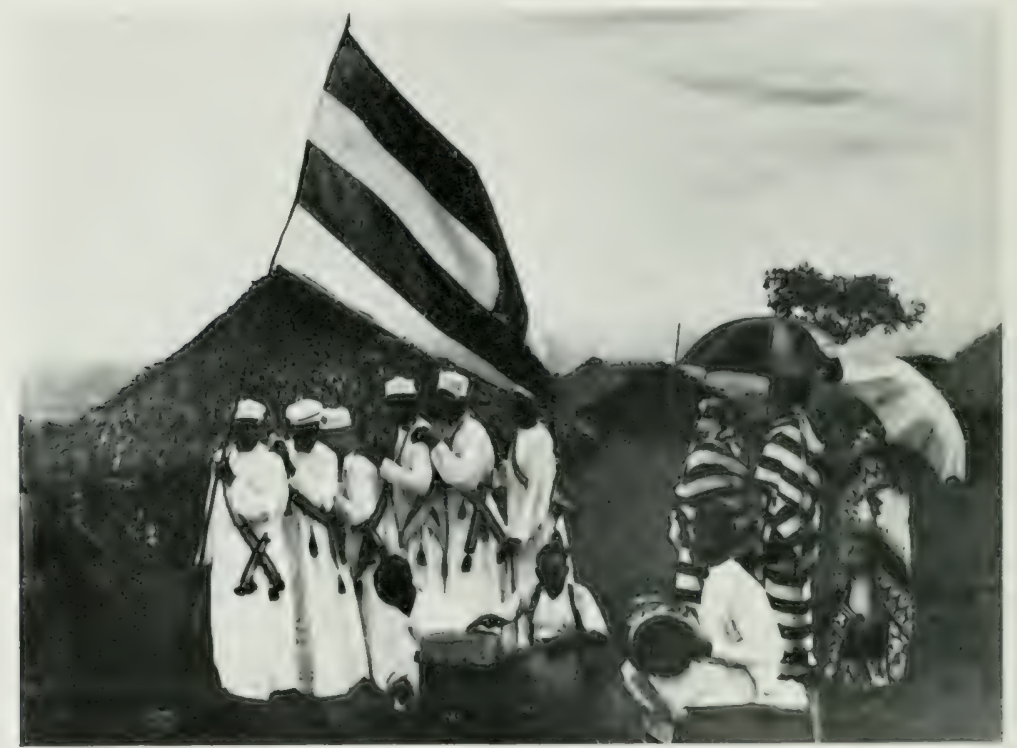

MY "BOYS" - BODY-SERVANTS AS DISTINGUISHED FROM 13EARERS-AMUSED THEMSELVES AT MOSCHI BY ORGANISING WHAT IS CALLED A " GOMA."

this danger was all but past now that we were entering the uninhabited region of the Nakuro, Elmenteita and Naiwasha Lakes, in the district known to the Masai as En'iniposhi.

Endless undulating expanses of grassy country, unadorned by a single tree, had made our last days of marching not too pleasant. Now there was a marked 
downward incline of the grass-covered plateau; it graduilly. changed to a barren plain of volcanic origin, and the vicw extended over the wide glittering lake.

Filling a far-stretching hollow, and lost to view on the horizon, it lay at our feet, a welcome sight.

The camp was pitched beside a parched-looking

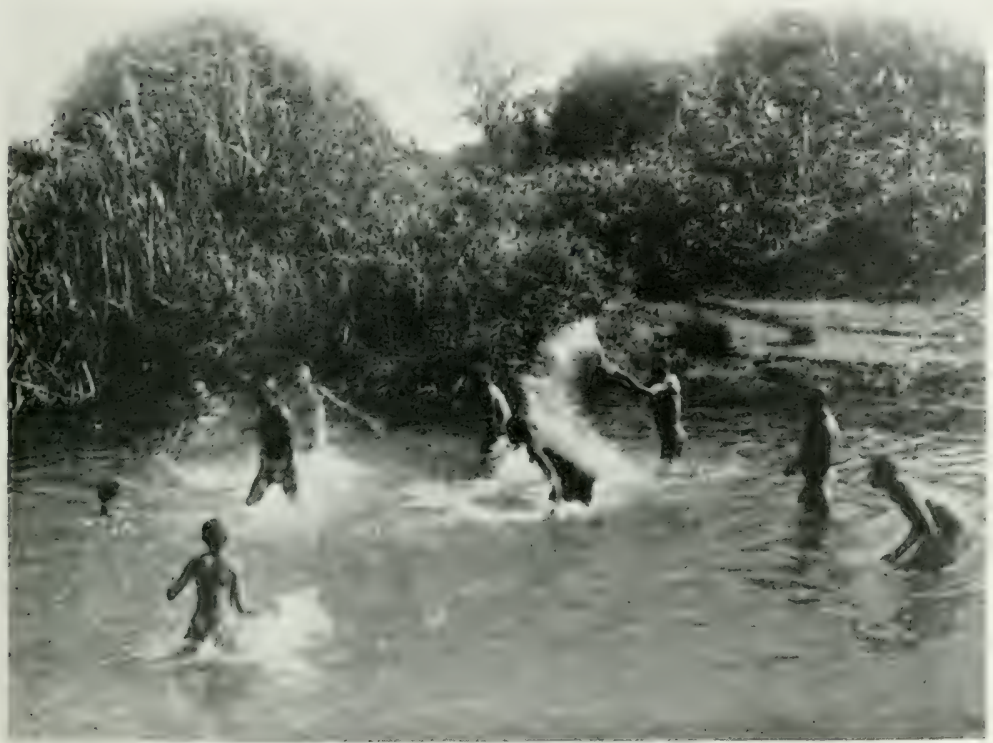

MY BEARERS LOST NO OPPORTUNITY OF INDULGING IN THE ENJOYMENT OF A BATH.

'msuaki tree on the banks of a brook which at this time of the year was a turbid torrent pouring itself down towards the lake. Some time before, bush and grass fires had raged in the neighbourhood and destroyed the old grass, and here, it would seem, a heavy rainfall had conjured forth for us a new carpet of grass that was fresh and luxuriant. The remarkible luxuriance of the grass

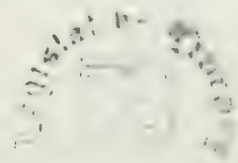


lands in the district had already been specially noticed, and compared to the richest pastures of the Swiss Alps, by the discoverer of, and first traveller in, this region, Dr. G. A. Fischer, an explorer who, alas! so soon fell a victim to the climate.

Fischer-in $188_{3}$ - was the first to visit the neighbouring Lake Naiwasha. How the situation has changed

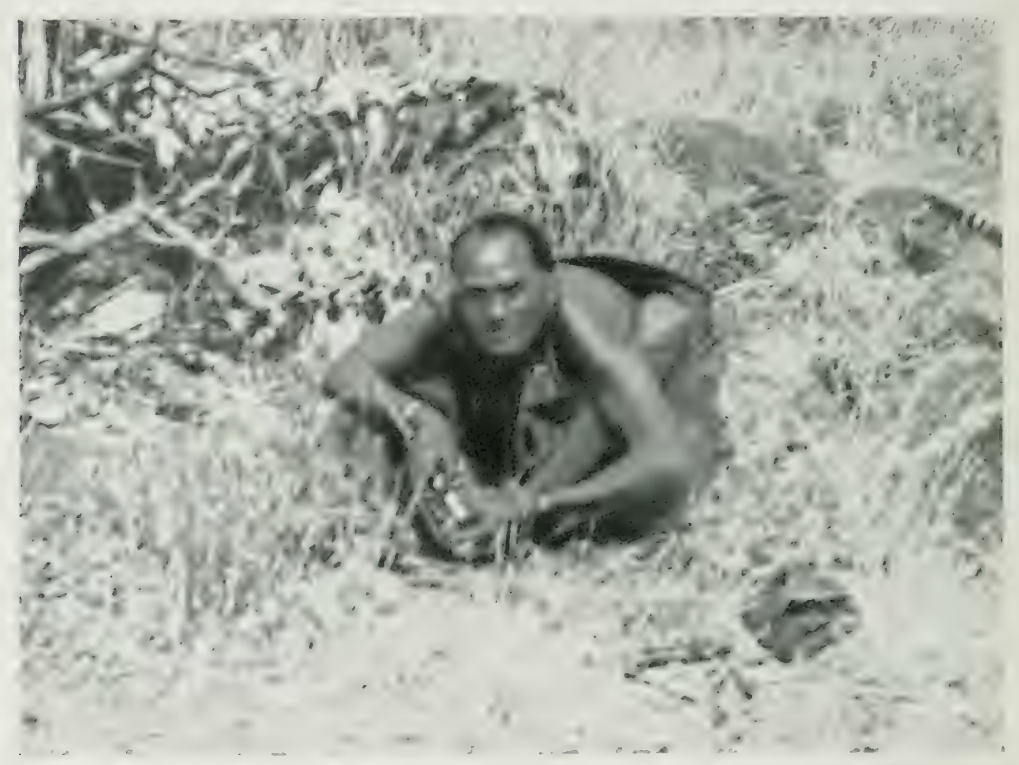

A MASAI ol' moman (i.e. OLD MAN) ANSWERING MY QUESTIONS ABOUT THE IELELESCHO PLANT.

since then! At that time, and thus only twelve years before I first camped there, the warlike Masai still held these wide uplands as absolute masters.

Oscar Baumann, an explorer who did good service, wats ane of the lirst to tratrerse their inhespitalle deminions. It was some years after Fischer's journey that Baumann 


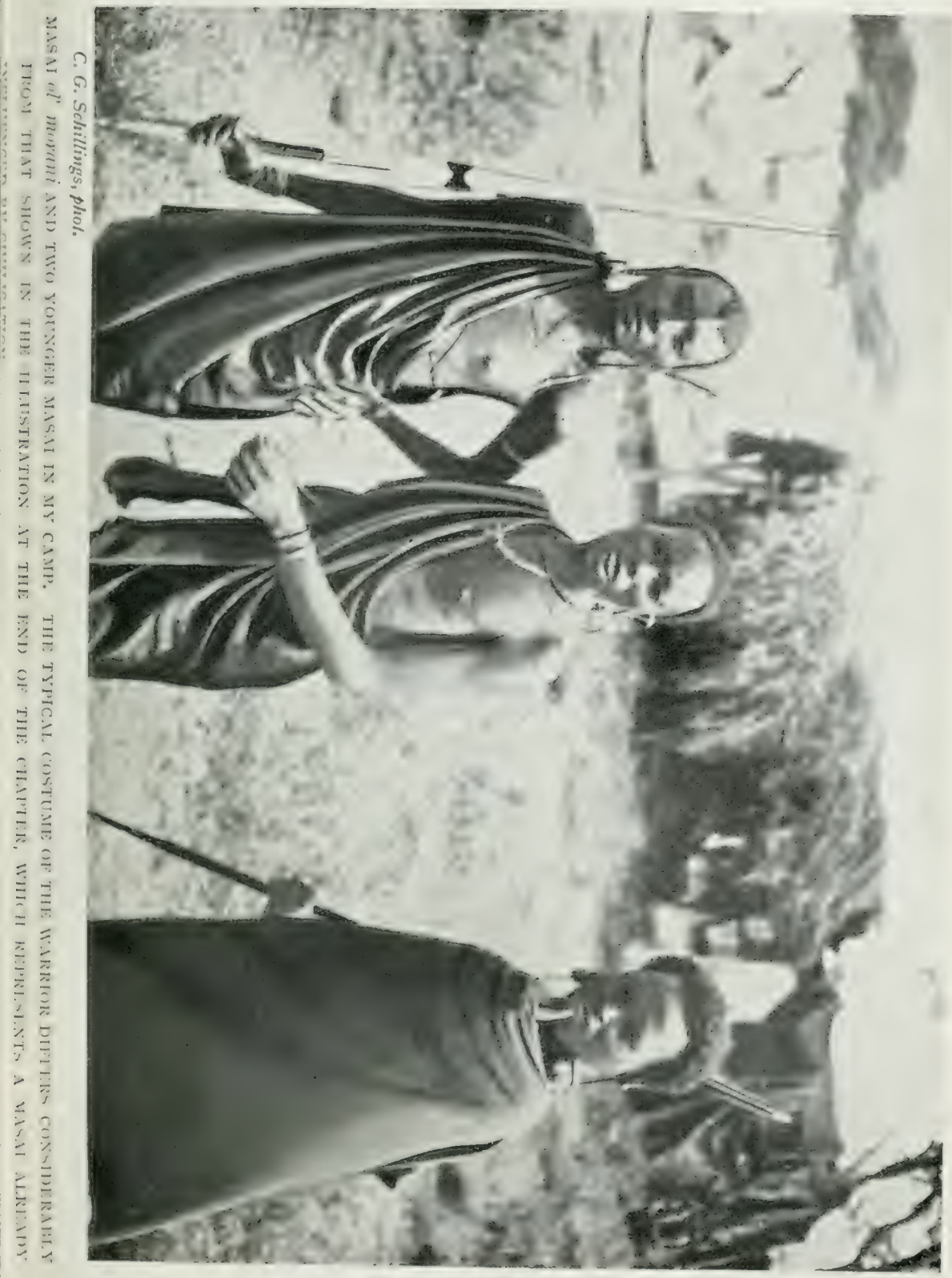



made his way into the region of the Nile sources, during his famous expedition to legend-haunted Ruandis (now better known to us through Dr. Richard Kandt's researches). I made his acquaintance at the Austrian Consulate at Zanzibar. He, also, was snatched away in his early years by the Sphinx of Africa, the treacherous climate.

His journey, only a few years before my stay here, cost his numerous and strongly armed caravan hard fighting with the natives. And now I am camping here with a few men in an unfortified camp!

Fischer was quite convinced that he could not venture upon his exploring journey without the support of the Mohammedan trading caravans, but he had finally to start alone with 230 bearers. Yet, notwithstanding all difficulties, he successfully accomplished his task. But how different from those of to-day were the circumstances under which a journey was made into unknown Masailand at that time! The Masai warrior was then still sovereign master in his own land; he was still "Ol open 1 en gob" ("Lord of the land") in the full sense of the word. And all the chivalrous poetry that has been so pathetically brought home to us by the fate of the North American Indians, was also not alien to his warlike character. Then came the moment when he had to face the firearms of the Europeans. His fate was sealed, like that of the lion and the leopard.

Then, too, tribute had to be arranged for on all sides. Not only some of the petty chiefs in the neighbourhood of the coast, but the Masai too, must receive costly payments. Thus, for example, Dr. Fischer had to hand over to the 


\section{In Wildest Africa}

chief Sedenga at 'Mkaramo on the Patsani River, to obtain permission for the passage of his caravan, 100 pieces of cloth, each six yards long, an axe, roo leaden bullets, one ten-pound lieg of gunpowder, two large coils of brass wire, and eight pounds' weight of artificial pearls!

Only two kinds of caravans were known to the Masai, slave caravans and trading caravans, which busied themselves with collecting the coveted ivory tusks. The Arab traders knew how to combine the two objects: the slaves, the "black ivory" of the trade, were forced to carry the white ivory down to the coast.

The strength of these trading caravans, well equipped with firearms, always amounted to several hundred men; but under certain circumstances these numbers were considerably increased, so that caravans of a thousand men or even more were not rare. It took Fischer long months to recruit his caravan. The bearers did not like to undertake the dangerous journey with the first white man who started for that region. The jealousy of the Arab traders was also at work. They feared that the channels of the ivory traffic, which they carefully kept secret, might be revealed.

The German explorer carried through his expedition under the greatest difficulties. He returned home only to succumb soon after to the extraordinary hardships he had endured.

Fischer's researches were of special importance in connection with the ornithology of Masailand. ${ }^{1}$ His journey gave to science some thirty-six hitherto unknown

1 Cf. Reichenow, Dic Viggel Afrikirs. 


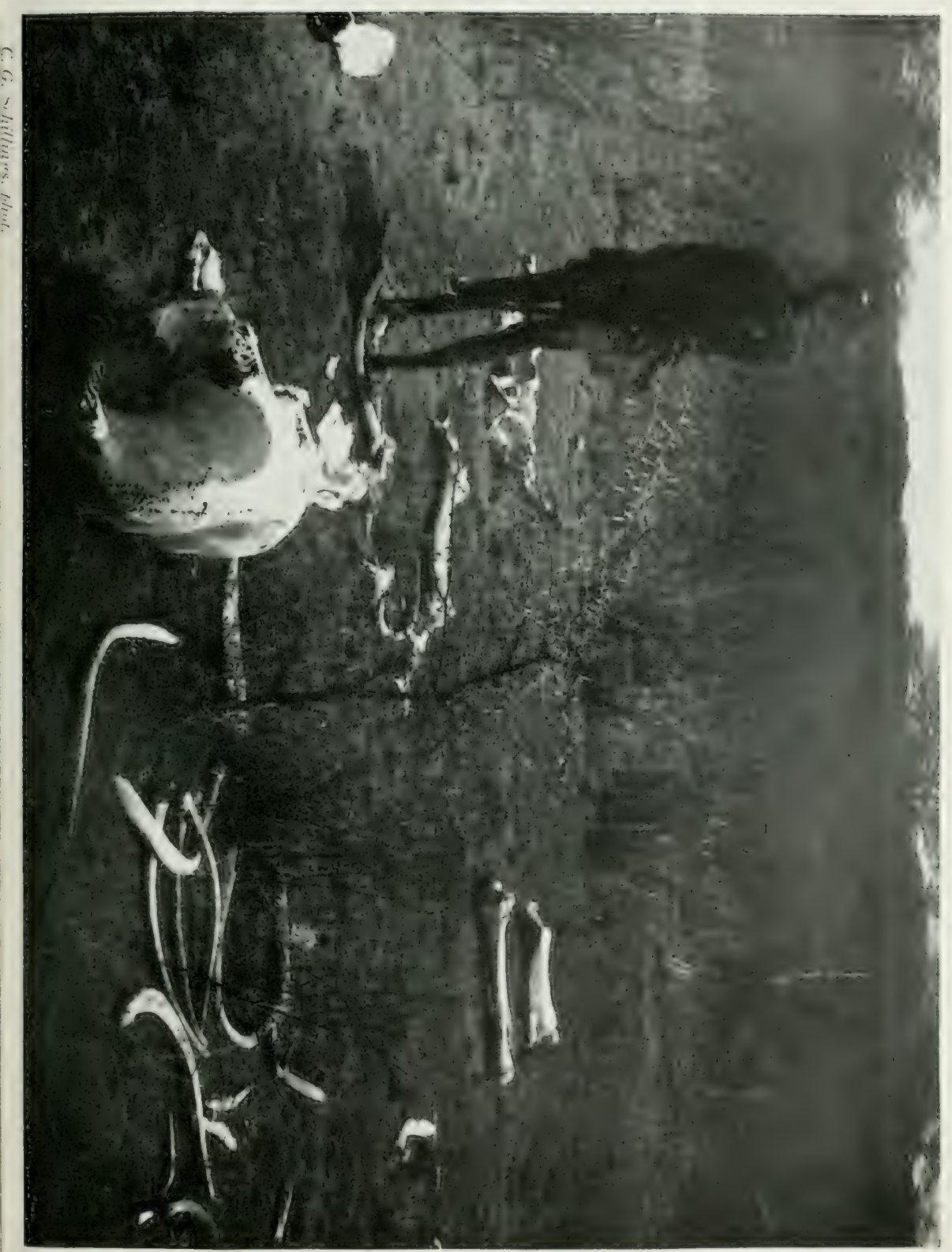





\section{- The Spell of the Elelescho}

species of birds. Such a result must indeed command our respect, when we consider the difficulties with which the traveller had to contend, and especially when we remember that his available resources were comparatively trifling, beside, for instance, the abundant help that was at the disposal of the English explorers of the same period.

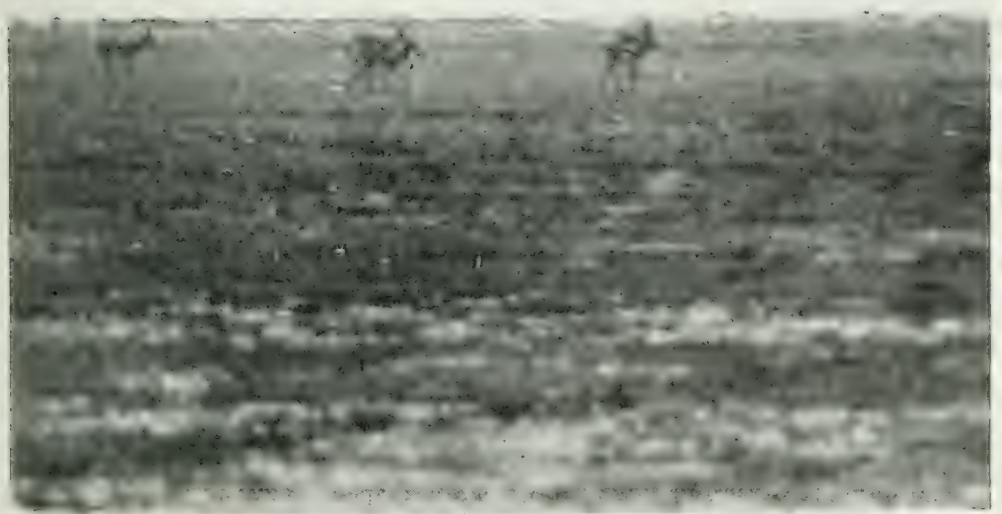

DWARF GAZELLES ON THE VELT. IN THE EDDYING WAVES OF DAZZLING LIGHT ONE COULD NOT KEEP ONE'S EYES OPEN FOR MORE THAN A SECOND AT A TIME.

The Geographical Society of Hamburg rendered him the service of making the execution of his plans possible, and for the same object Fischer expended all the money he had earned in the active practice of his profession as a doctor on the island of Zanzibar. He saw the activity he had devoted to the service of scientific ideals richly rewarded by the results he obtained. And then he had soon to 


\section{In Wildest Africa}

succumb to the treacherous climate. But it his life was cut short, how quickly the power of the Masai warriors was broken, the very power that had so harassed him, and made his journey so difficult and dangerous. That terrible scourge, the cattle plague, probably introduced from India, suddenly destroyed the greater part of the herds of the Masai, and at the same time blotted out vast numbers of the Masai themselves from the list of the living.

The fates of these pastoral people and of their property (the countless herds of cattle) were so closely bound together, and these warlike herdsmen had become so dependant on their droves of cattle, that once these were ruined they could not survive, but died in a few days of famine.

In the lapse of little more than a year the cattle plague and the Black Death had swept over the Masati uplands. Hungry vultures hovered over scenes of horror. The herds of cattle fell under the strange pestilence. Agronised by slow starvation, the herdsmen followed them to death. I have often found lying together, in one narrow space, the countless white bleached bones of the cattle and the skull of their former owner. It would be an old campingground, with its fence of thorns (zereba) long rotted away, and it was now a strangely impressive Golgotha. These heaps of bones, still to be seen in 1897 , were soon after dissolved in dust and scattered by the winds.

Where are the Masai of those days?

Suddenly they stand boldly before me, as if they had sprung up out of the ground! It is no illusion. 

But why do my bearers show no fear? Why does no uproar break out in the camp?

It is plain enough that no one troubles himself about the appearance of these figures, for they comc, not threatening and demanding tribute, but conscious of the overpowering might of the European. True, a few months ago, not so far from my camp, their warriors surprised and destroyed a caravan of nearly a thousand coast folk. But, generally speaking, they do not care to have to reckon with the superior weapons of Europe. They even accept some food from me. And in this matter they are not so dainty as they used to be in former times, when the warriors - obedient to strict dietary laws lived only on the meat and milk of their herds. Of course, here we have to deal with only a small number of them. Yonder, on the wild uplands, there still live a not inconsiderable number of Masai, who having saved their herds, or got them together again, keep as far away as may be from the Europeans and their uncanny weapons.

The Masai warriors, with their wives, children, and herds, seem to me to be fit accessories for this desert landscape. In the evening, dances amuse us till late in the night, and many a wordy skirmish breaks out as some of my bearers who, thanks to former journeys, have some knowledge of the Masai tongue, gossip with these nomads of the wilderness. The coast folk think themselves high as the heavens above the "savage" Masai. The Masai warriors, in return, despise the burden-bearing coast folk, count them as "barbarians," and scornfully call them "il'meek." 


\section{In Wildest Africa}

But the times have changed, and so it comes to pass that my people too join in the dance, which lasts late into the night; that songs of the warriors and the women"'Singōliōitin loo-'l-muran" and "Loo-'ngorōyok" - ring out throush the darkness, the chorus finding a manifold echo with its oft-repeated "Ho! He! Ho! Na! He! Hoo!" It is a "Leather Stocking" kind of poetry, and indeed the redskins of the New World and the Masai here in Dark Africa seem to me alike. The former had to yield to civilisation, the same fate awaits the latter.

No one had the least anxiety about the night. We quietly allowed the Moran ${ }^{1}$ to bivouac near the camp. Our march through the wild highlands of the Wasotiko and the IVanandi had deadened our sense of such dangers. We could have no forebodings of the fierce struggle lasting for years that was yet to come between the English troops and those peoples, or imagine how warlike and skilled in self-defence they were. The presence of hundreds of spear- and club-armed warriors in the camp had become an almost daily experience, and great was the surprise of the English officers, later on, when they heard that the great caravan, which I had joined, had had the grood fortune to pass through these districts without any fighting.

Fior me my serious illness had all at once interrupted the anstere and wild delights of this life of the march and the caravan. But I had now become doubly responsive to the joys of travel amid light and air, freedom and endless space; doubly responsive also to the changing

1 El momn = the "young men," i.e. Masai warriors. 


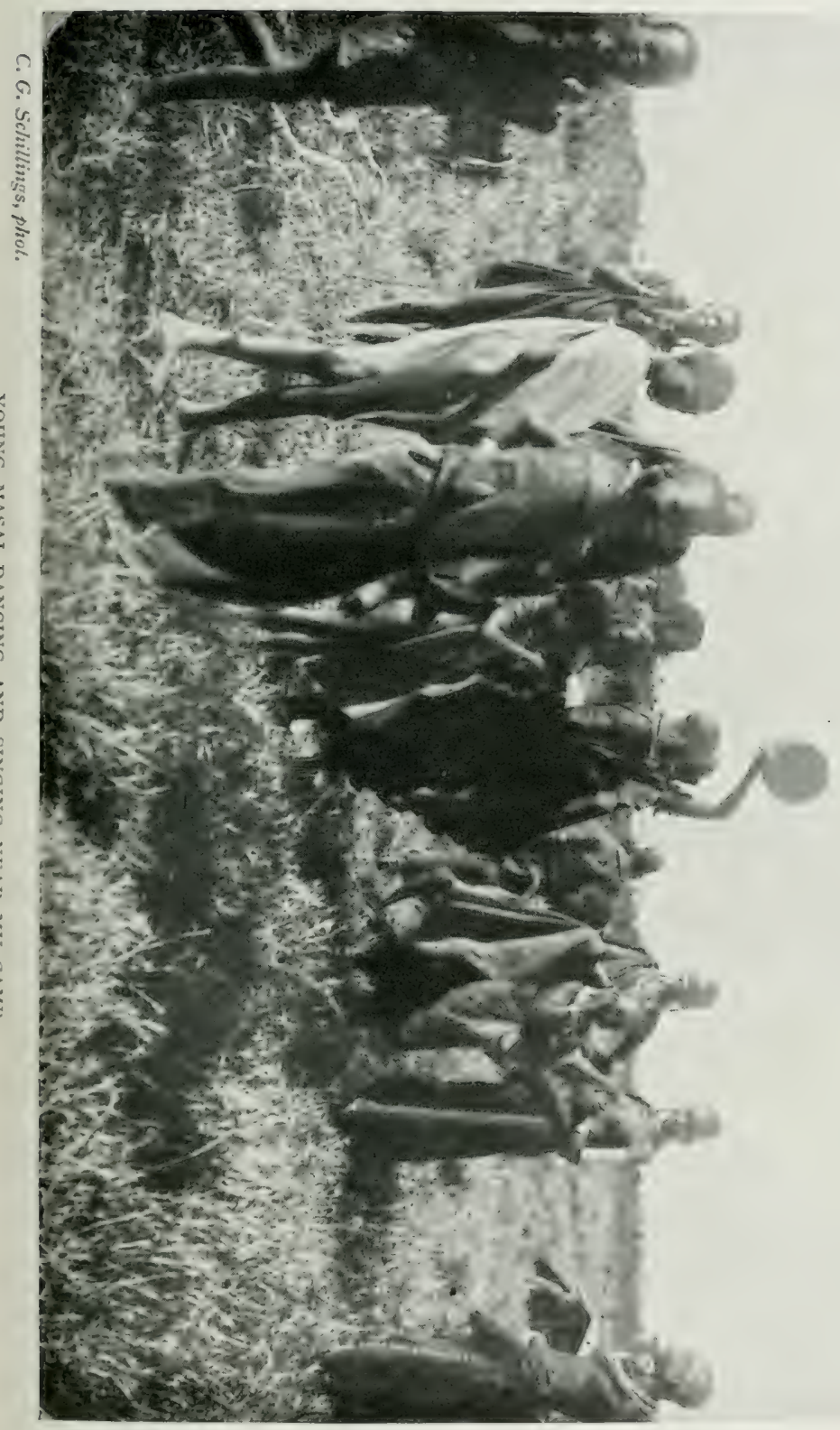

VOL. I 

impressions derived from my week of marching throush lonely primeval forests, bamboo thickets, and grassy plains-scenes in which, as my friend Richard Kandt, the discoverer of the source of the Nile, so strikingly remarks, ${ }^{1}$ every plant, every stone, seems to cry out again to one in the vast solitude but one word: "The desert! the desert!"

In the early morning hours of January i 5 there was a light continuous rainfall. A short march of only two hours brought us to our camping place on the shore of Lake Nakuro.

Far away extended the panorama of the lake, which lay before us filling its, hollow bed, with its banks at this season of the year yielding fresh pastures to numberless herds of wild animals, and its waters affording rest and food to countless members of the feathered tribe. I had hardly ever seen greater numbers of the pretty little dwarf gazelles (Gasella thomsoni, Gthr.). Thousands and thousands more of these graceful creatures showed themselves on the fresh, green, grassy meadows of the lake margin, or scattered over its pebble beds of obsidian, augite, and pumice-stone. Wherever one turned one's gaze it fell again and again upon these beautiful gazelles, which in many ways reminded one of wild goats at pasture, and were so strangely trustful that they often allowed the spectator to come quite close to them. Marked as are the colours of its hairy covering, the dwarf gazelle does not stand out boldly from the background, whether this be a plain blackened by bush-fires,

1 Dr. Richard Kandt, Caput Nili. (Berlin: Dietrich Reimer.) 


\section{In Wildest Africa}

or the mere bare ground, dun-coloured and brown, or land covered with soft green grass. But how clearly defined are its brown, black, and white, when we look closely at the hide of a specimen we have secured, or see it in a museum.

Darker spots in the distance far away from us we take to be larger wild animals. The field-glass shows that they are hartebeests, and a great number of waterbuck; and still farther off there is a moving mass that shimmers and is half lost in the glare of the morning sun. There are zebras, and yet more zebras, moving like living walls! Strange effects of liwht actually grive us the impression of something like a wall or rampart, made up of the living forms of the zebras-the deep shadows they throw come out black, their flanks are lighted up in the dazling sunshine, and they shimmer with all colours and with ever-changing effect.

Here by the lake we have the characteristic mark of the wilderness: dwarf gazelles and zebras, zebras and dwarf wazelles in greater and greater multitudes! Wherever the eye glances it falls upon these two species, and the numerous waterbuck and Grant's gazelles, and the hundreds of hartebeests, are in a sense mere points of relief for the sight amidst these vast crowds. Bathed in the shimmering light this multitude of animals mingles together. Wherever I make my appearance there is for awhile movement in the mass of wild creatures, which otherwise are grazing quietly. I have long since left the camp a considerable distance behind me. I am following one af the rhinoceros-or hippopotamus-traks leatling to 

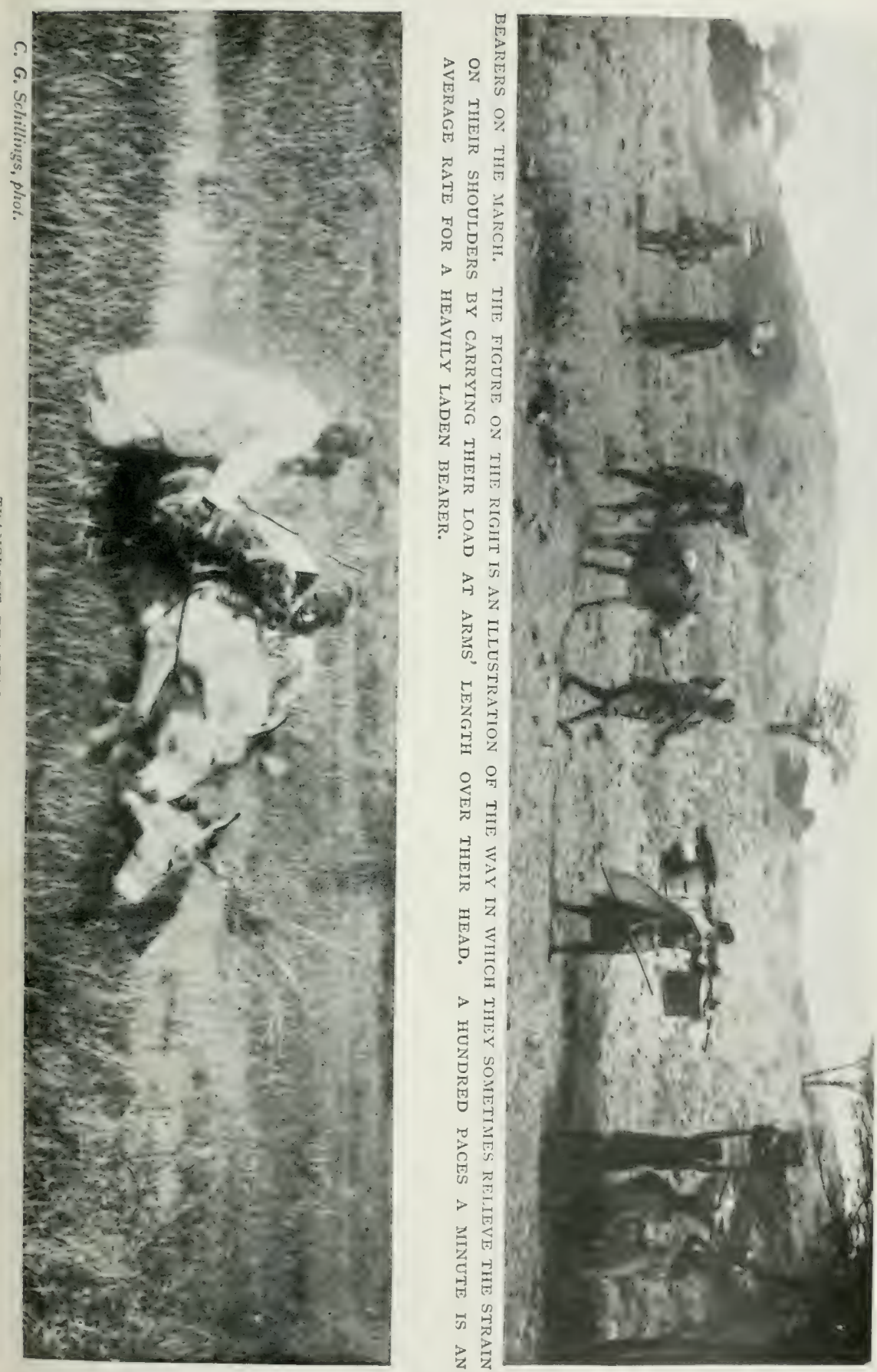

the lake margin, lost, so to speak, in this multitudinous animal life, and once more I have the feeling of finding myself, as it were, in the midst of a vast flock of sheep, and the impression that all the creatures about me are not "wild beasts," but rather tame domestic animals that have

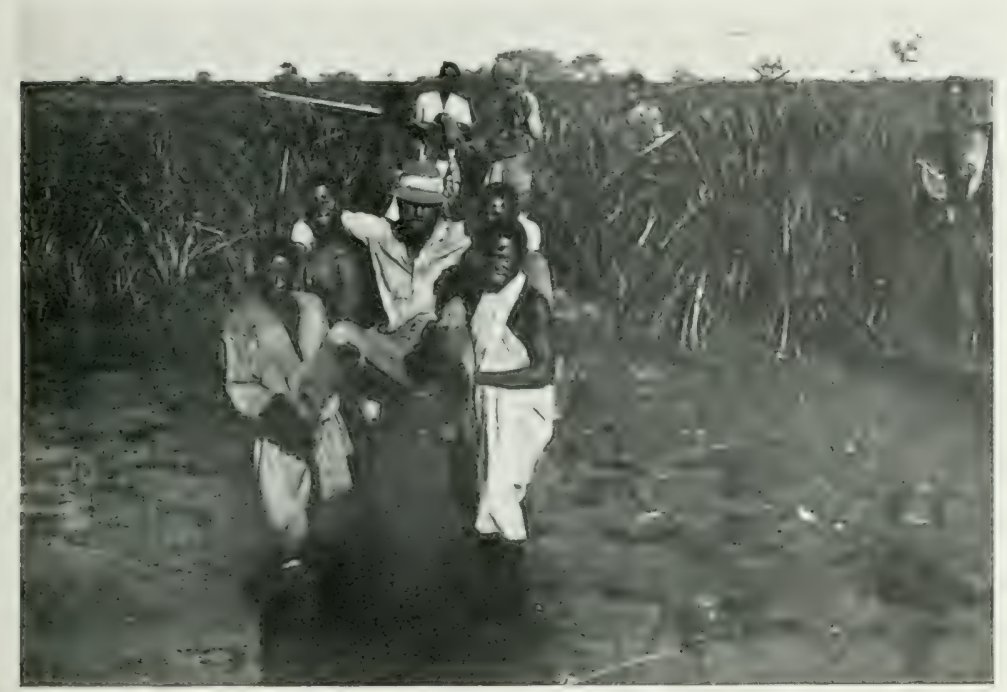

THE AUTHOR BEING CARRIED ACROSS A SWVAMP.

been driven out here to graze on the pastures under the supervision of a herdsman.

The mass of animals surges and undulates to and fro. Some old bulls of the hearily horned hartebeest species seem to have undertaken the duty of sentinels. They stand apart fixed and motionless, watching attentively the strange appearance of the approaching man, and then make away in a long striding gallop, with heads bent well down, to increase the distance between themselves and 


\section{In Wildest Africa}

the suspicious olject, ready all the while to wive the alarm signal for a general stampede by loud snorting. In this district we do not find the flat-horned hartebeest of the Kilimanjaro (Bubalıs cokei, Gthr.), but the species named after its discoverer, Jackson (Bubalis jacksoni). Long and stately horns distinguish this variety of a remarkably formed species of antelope, which is widely

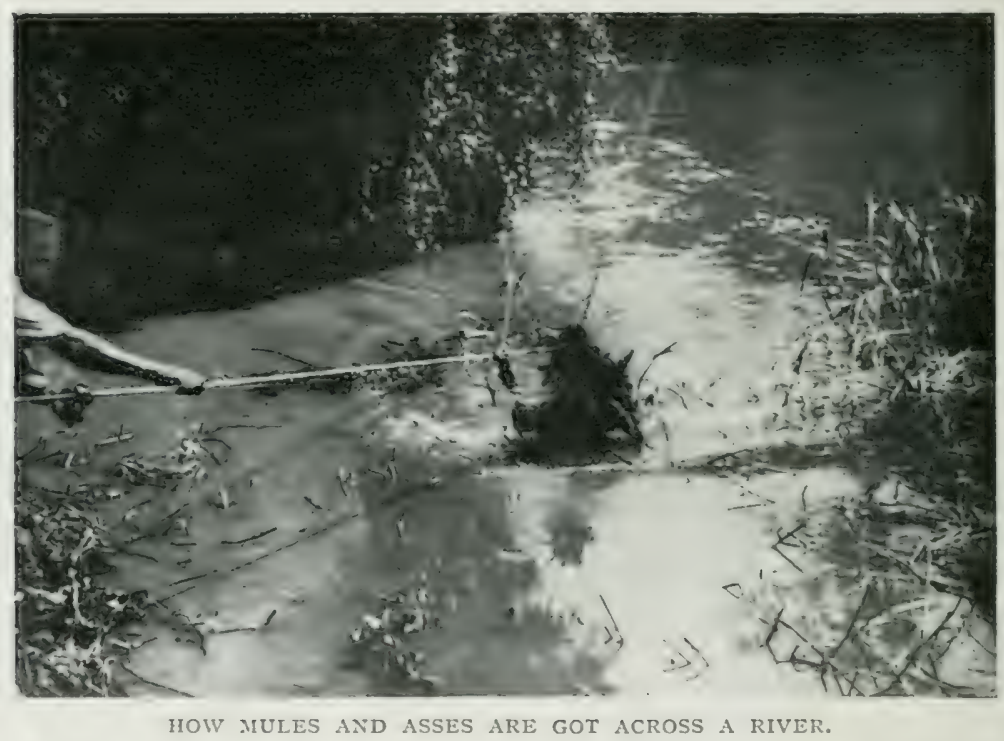

distributed throughout Darkest Africa. To my sreat delight I succeeded in bringing down a specimen of a much more interesting species, Neumann's hartebeest ${ }^{1}$ (Bubalis neumanni, Rothsch.), then only known by one or two examples.

I I gave the skull of this specimen to the Berlin Natural History Museum. 


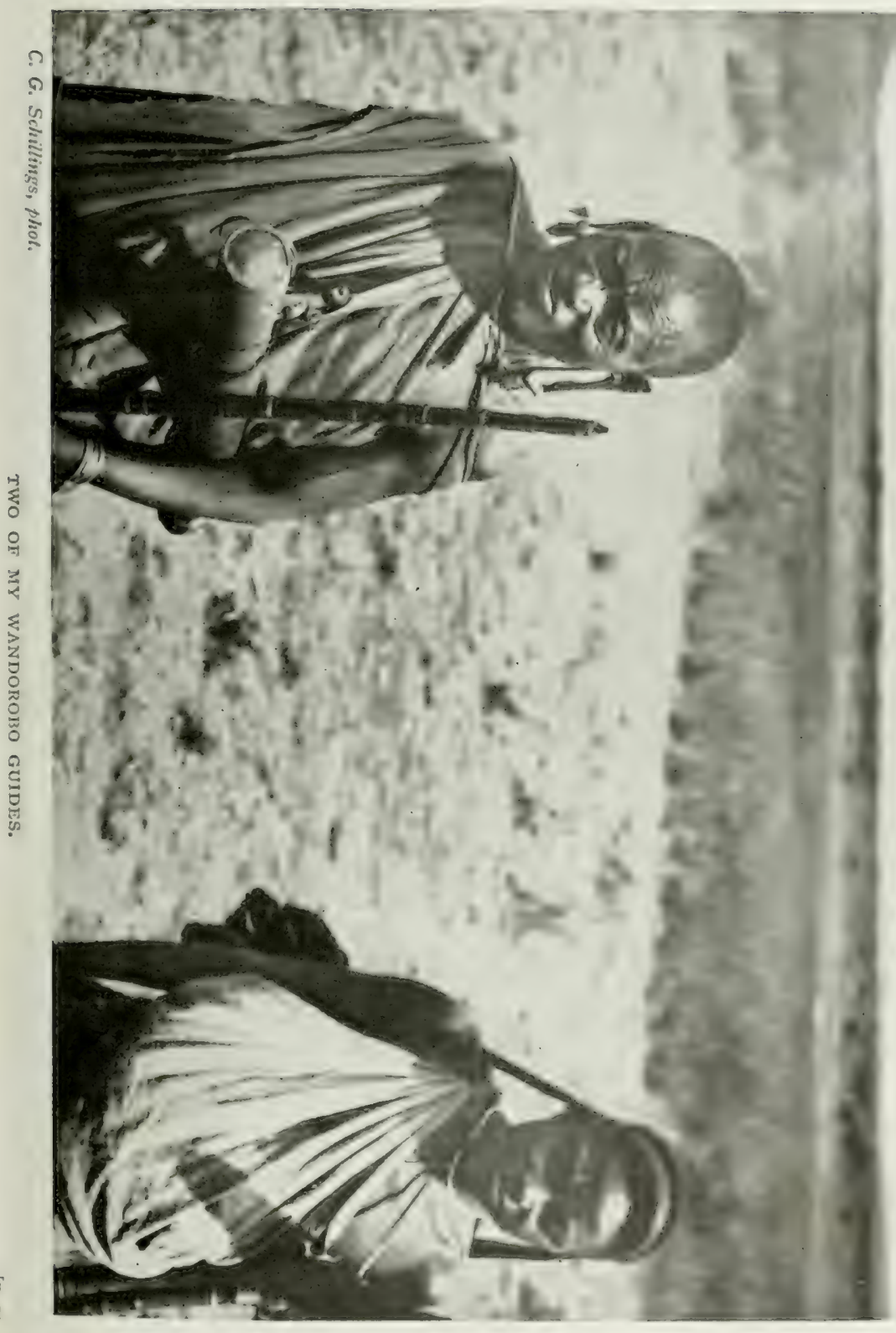





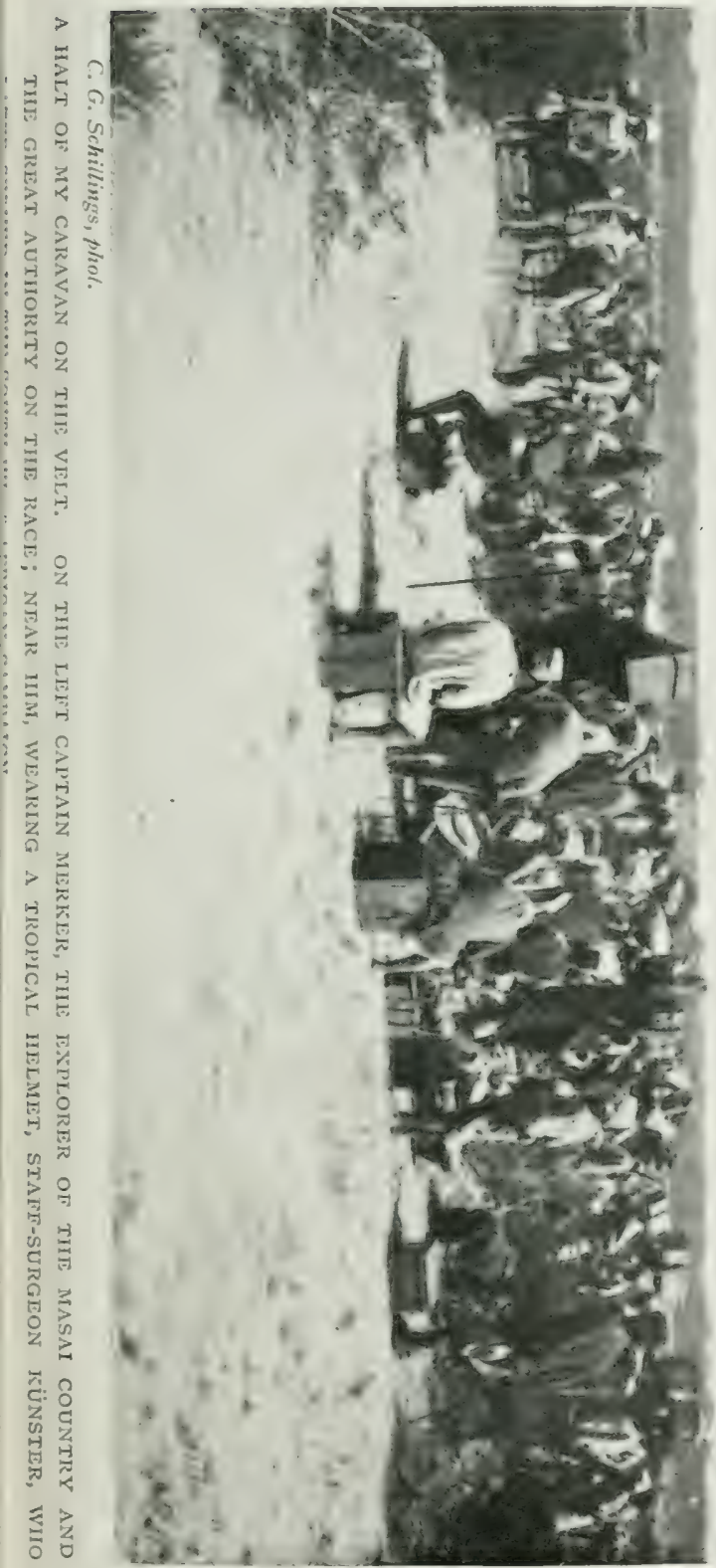





\section{- The Spell of the Elelescho}

Overwhelming in its vastness, its rich variety of colour, form, and movement is the picture of animal life thus displayed.

Moving along the hollows of the plateau hour after hour, looking out from its ridges, now with the field-ylass, now with unaided sight, I find the whole grassy expanse covered with these wild creatures. Hundreds and hundreds more of zebras alternate with larger or smaller herds of Grant's gazelles. Near them, but keeping apart, and all around them the dwarf gazelles are swarming. Here and there one sees the proudly uplifted head of a stately waterbuck, adorned with splendid branching horns, and not far off his hornless doe, both of them in form and action greatly reminding one of the stag of our northern lands. Occasionally the eye catches sight of splendid black-plumed cock ostriches here and there on the plateau. They watch the traveller carefully, and are accompanied by their mates, which are very much more difficult for the eye to make out owing to their plain grey plumage. On all sides there are whole herds of brown hartebeests grazing. resting, or making for some more distant spot with their characteristic long striding gallop. And now one suddenly comes upon a herd of giant eland antelopes, brownish yellow, and adorned with white cross-stripes. Conscious of their mighty strength, there is not much shyness about them; but they know not the danger they run from the long-range weapon of the European.

Think of all this animal life bathed in the fulness of the tropical sunlight! All depthis and shades of colour play before our eyes. Strongly cast shadows, ever changing

27

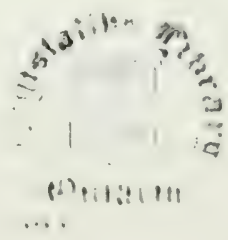


with the position of the sun, alter again and again the whole appearance of this world of life, and from minute to minute it presents new riddles to any one who has not had years of experience in the wilderness. When the glittering light of the midday hours is tiring and confusing the sight, one often can hardly tell for certain whether it be a living multitude stretching out in the distance before one, or whether the play of the sunlight is imparting a semblance of life to scattered clumps of thorn bushes.

Four rhinoceroses which I now descry moving across the plain in the distance, and a flock of ostriches which I can plainly make out with the field-glass, change shape and colour so often that it is astonishing to see them. According to their movements and position with respect to the sun they appear to be of a blending blue and grey, or intensely black, and then again almost invisible and the colour of the earth, but always changing, always different from what they were the moment before.

To realise all this one must in fancy place oneself in the condition of exaggerated susceptibility to nervous excitement that results from the intensity of the light, together with the climate, and the unusual degree of hardship. All this produces the greater effect because one has to do one's work in solitude and loneliness, and is cut off from all interchange of ideas with one's fellows.

Here, where the flora makes so poor a display, the fauna is abundant. What a sight it affords for the ornithologists!

Amongst the herds of zebras our European stork 28 


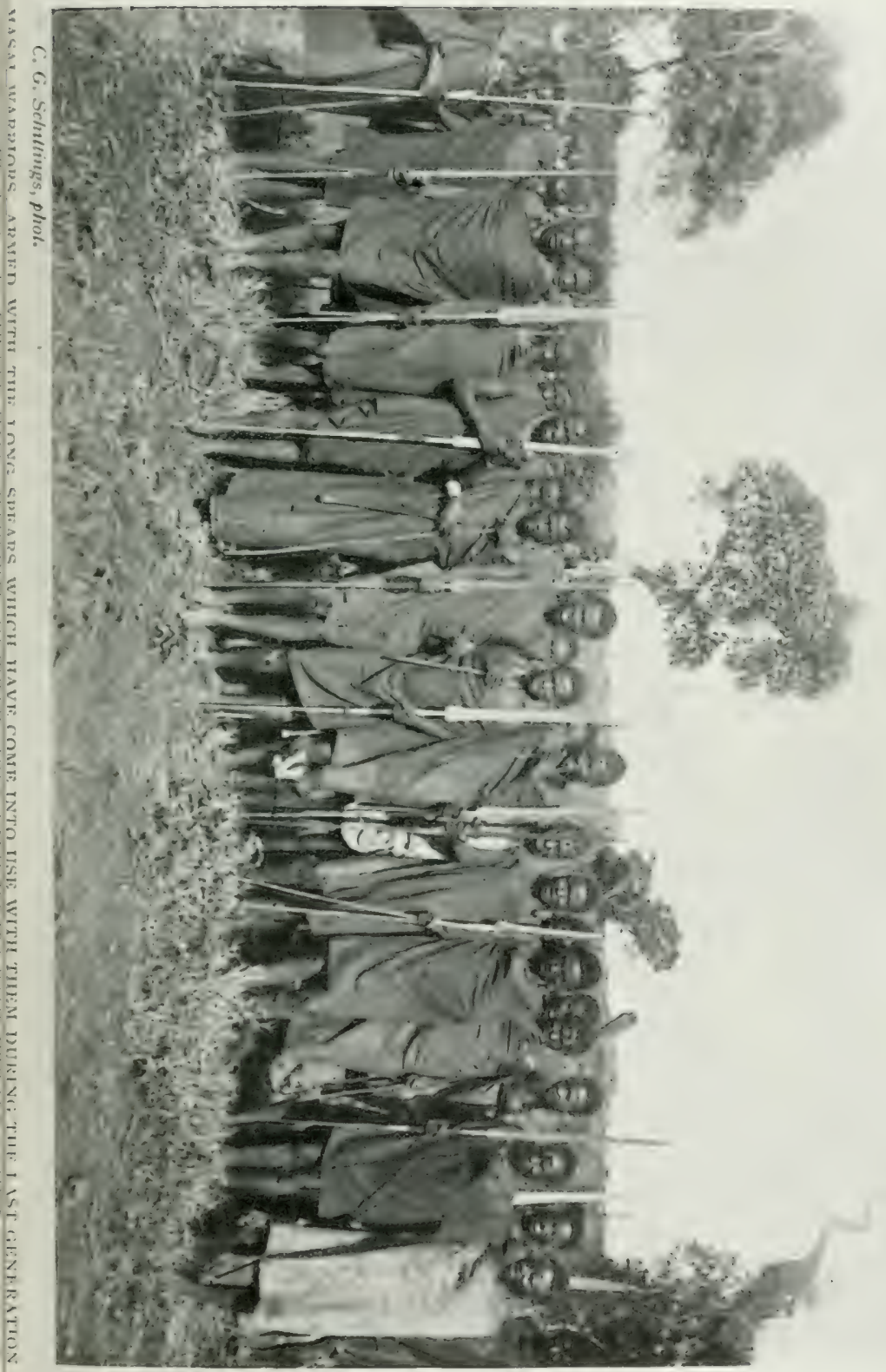



together with its smaller African cousin, the Abelim stork, is stalking in hundreds over the plain hunting for locusts. In company with the storks I saw also great flocks of the handsome crested crane engaged in the same occupation. Or they rose in heavy flocks over the valleys with loud and strangely discordant cries. Under the scanty shadows of the mimosas the splendid giant bustards take their stand at midday, erect, solemn, stiff-necked. At this time they are not very wary, but in the coolness of the morning and in the evening hours they soon get away to a safe distance, either running with their quick mincing step, or spreading their strong pinions for a short flight along the ground. Their smaller relative, Otis gindiana, Oust., rose before me in the air, often throwing somersaults on the wing like a tumbler pigeon. There is hardly any other bird of its size that has such a mastery of flight. Sea-eagles circled by the margin of the lake uttering their beautiful clear-sounding cries. Heedless of their presence thousands of splendid rose-red flamingoes soared up into the deep blue dome of the sky, or lined the margin of Nakuro, like a garland of living lake-roses, in company with great flocks of ducks, geese, and waterside birds of many kinds. Out of the clumps of acacias, and from between the thickets of 'msuaki bush by the lake, guinea fowl and francolins rise, strung out in clattering flying lines, and in the morning hours handsome sandfowl that have come from far-off regions of the plateau sail by the margin of the lake. Altogether an overwhelmingly rich picture of warmly pulsating life and activity! The sight of it all is indeed quite capable of impressing one with 


\section{In Wildest Africa}

the idea of flocks of wild creatures that have been completely tamed ; and once this idea has suggested itself, the impression is so strong that for many minutes one can believe in it!

Amidst all this wealth of "wild" life, which here seems hardly to deserve the name of "wild," it is much easier to understand how primitive man in other continents gradually secured domestic animals for his use, from the vast range of choice thus presented to him.

But a strange feeling comes over the observer when he remembers that out of all this wealth of animal life the African has never been able to link one single creature permanently to himself. He obtained his cattle and also his goats and sheep from Asia. The camel may be left out of account, for its connection with the human race is lost in the mystery of primitive times. We may say that the fauna of Africa has not given a single species to the group of our domestic animals. It is sad and humiliating to reflect that the men of to-day cannot accomplish what was done in the dim past-granted that it took endless ages in the doing.

There were times, as I have said, when I could not get rid of this impression of tame herds of animals. And this was all in a land, and a district, that left one nothing to desire in the way of primitive wildness. What, then, must it have been in early days when man was not yet waylaying the beasts of the wilderness, or at least had not yet employed the poisoned dart and spear, the pitfall and the snare? It must have been a veritable Garden of Eden. But here, far and wide, there is 


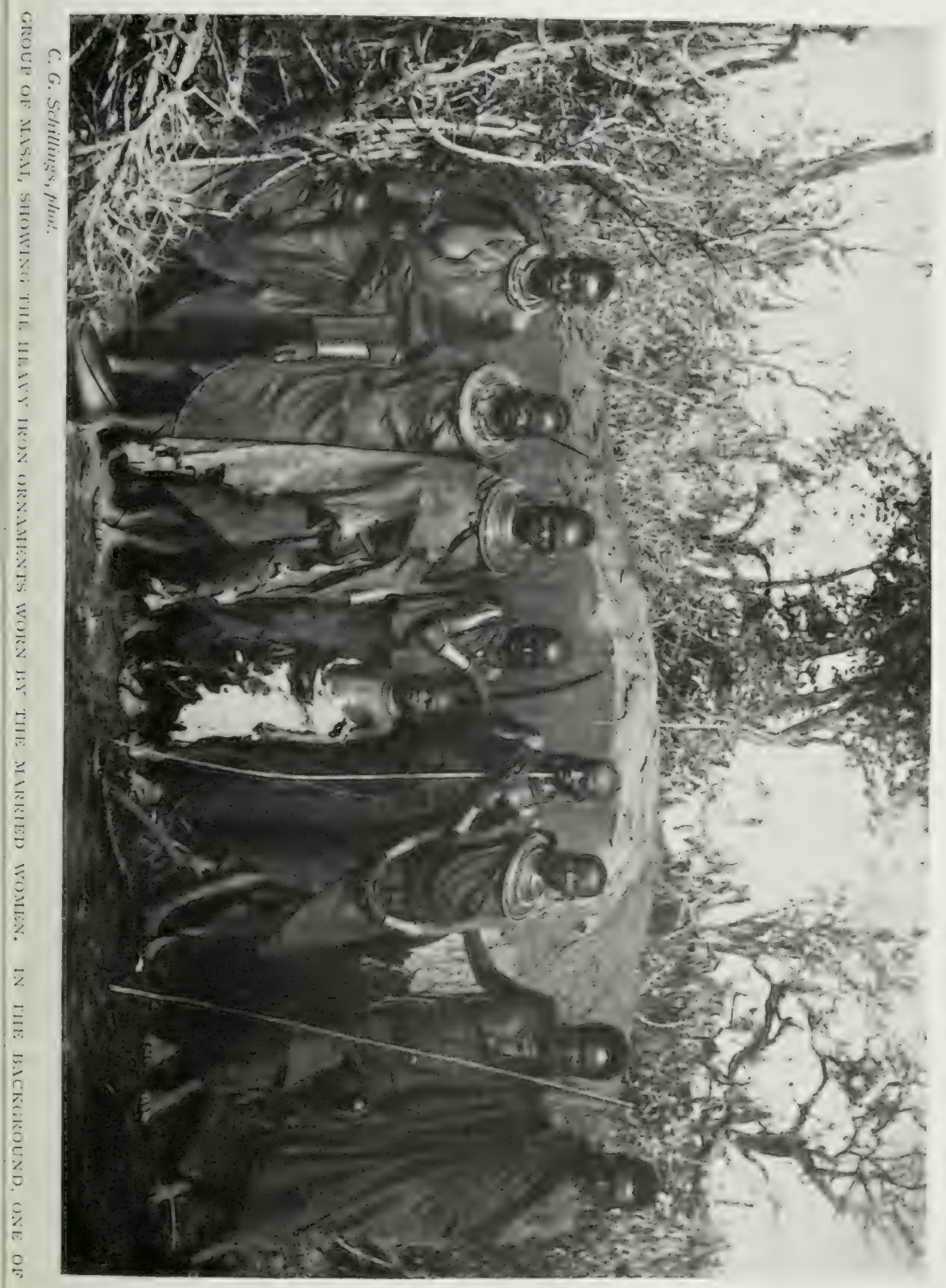

VOL. I 

nothing to be seen of man, only somcthing that cvolies conjectures as to his former presence.

For suddenly from a height I notice a number of large mounds, formed of stones, such as only the hand of man could have built up. Under the secure protection of these masses of rock-rough hillocks of heaped up stonesmen, who were once chiefs and elders of the Masai, sleep their everlasting sleep. Their resting-places have been so placed that they are not visible from any considerable distance, but are hidden away in the hollows of the ground. Out there in the wilderness, beneath the bright blue sky, these simple old monuments speak to me most impressively of the mighty harmony of everlasting change. As chance will have it, I find not far from the graves a human skull shining brightly in the sunlight and resting on a projecting rock. It must have lain here very long, as if keeping a look out on the old tomb of ol 'loiboni, the departed "wizards" of the Masai. The empty eyeholes stare at the ancient grave.

But this symbol of the past is not obedient to the spell of death that whispers here all night long, for it has had to give shelter and protection to the rearing up of new life. As my hand grasps the skull, now brittle with decay, a family of mice takes to flight from inside of it. They had set up their home in this bony palace, and built their nest there.

And as if the Masai, resting probably for centuries under these heaps of stone, had left their herds to me, once more there surges around me this sea of animals. Near at hand they are sharply defined against the ground, 


\section{In Wildest Africa}

but farther off in the glittering light they grow indefinite. How the whole flood of life contrasts with the grim volcanic barrenness of the landscape!

At this moment my impression of vast shepherdguarded herds is deepened by the sudden appearance of some spotted hyenas, scattering among the volcanic pebble beds, and then running away over the plain, and seeming to play the part of the shepherds' dogs.

But where are the herdsmen of all these herds? Immediately there comes an answer to my question. Yonder, by the margin of the lake, in the distance, I see little wreaths of smoke rising. The idea they give me of herdsmen on the watch is to be quickly dissipated by a report, not a loud one, followed by puffs of powdersmoke that vanish quickly in the air. The shooting does not disturb the animals that surround me. But then the report is hardly audible, the little puffs of smoke barely perceptible to the eye. I must find out who is disturbing the peace. It is perhaps a caravan making for the Victoria Nyanza. For we are upon the new "road" to the lake--a road which is indeed still in the region of projects, but which soon will be plainly marked with railway metal.

The smoke puffs appear at markedly regular intervals and as quickly disappear. I cannot understand it. For a long time I keep my attention anxiously fixed on these proceedings, all the while hurrying towards this remarkable apparition. At last my field-glasses enable me to descry a man, who from time to time drops on one knee to take aim. 


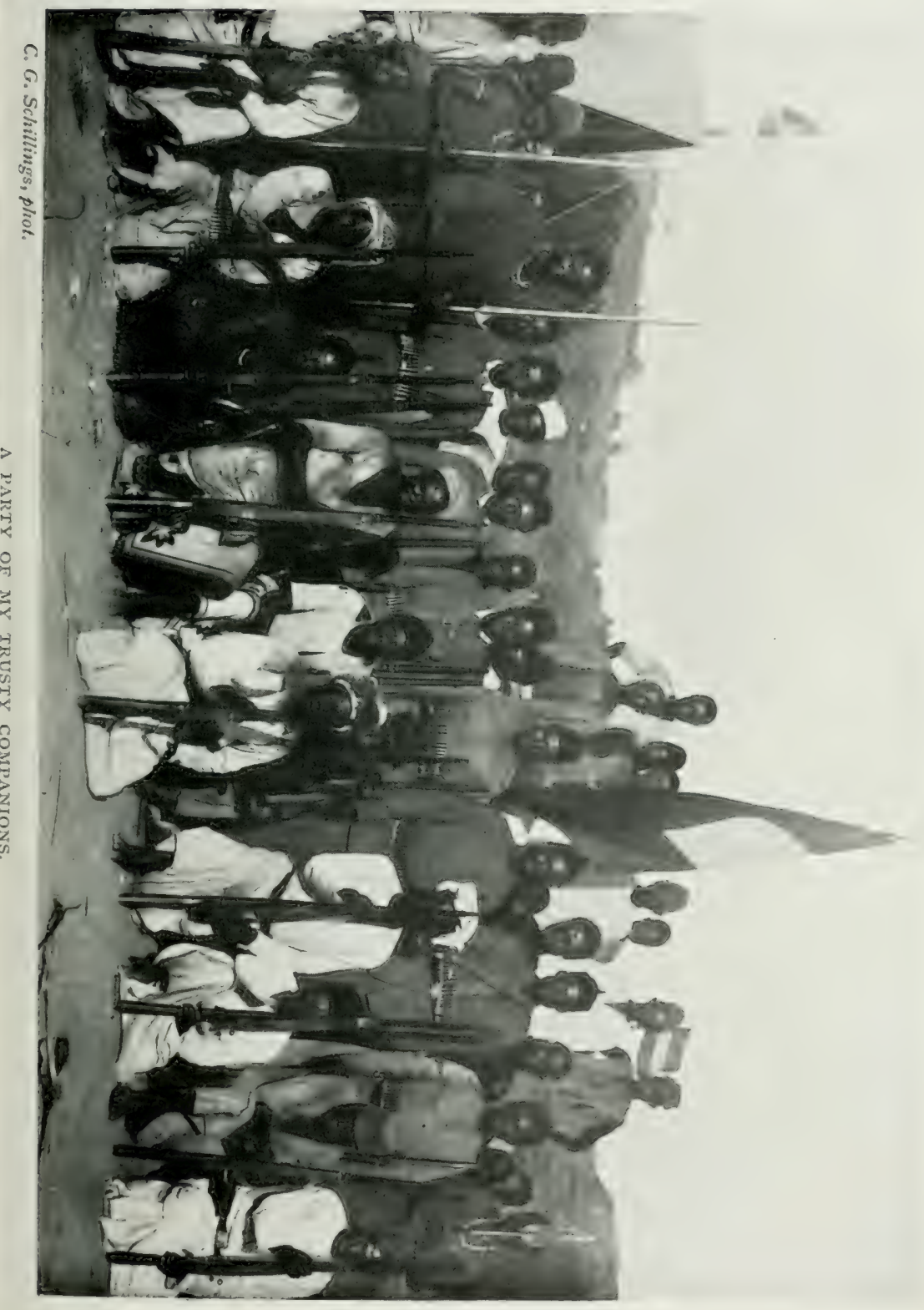



What in the world is he after?

As we draw closer, I am extremely surprised at secing that the man does not allow himself to be in the least disturbed in his proceedings. Now his bullets begin to whistle unpleasantly near me. I fire in the air, once, twice. . . Now his attention is attracted, and simultaneously I perceive a number of dark objects near the marksman. They seem to be his companions, black men, and squatting on the ground.

From the background there emerge now great numbers of such objects - it must be a large caravan.

The distance between us is diminished so that one can see plainly.... Now we can shout to each other... At last I learn that the hunter is marching with his long caravan of bearers to the great lake. He has been putting out all his exertions to shoot some wild animals. But although he has many surprisingly interesting hunting adventures to tell of as the result of his three months' march from the coast to this point, that task seems to have been beyond his powers! With a well-aimed shot he has stretched on the ground just one single dwarf gazelle!!

After shaking hands, he bewails the fact that he has a rifle that shoots so badly. He says its system is absolutely worthless, especially against wild animals.

Our fleeting acquaintance is broken off in a few minutes. He is the first newly arrived European that I have met for a long time, but I have not too much sympathy for this class of sportsmen. So my new acquaintance goes off, still blazing away freely. He has been urged on by my information that his camping and 


\section{In Wildest Africa}

watering place for the day is a long way off, and that the borders of the lake seem to me to be fever-haunted.

A queer kind of shepherd, in truth, for these wild herds! I fear he would be very like a wolf, or ratherto be zoologically and geographically precise-a leopard, in sheep's clothing!

Again I was alone; the disturber of my peace had not frightened away the animals. So, as I was regaining strength rapidly, I decided to halt here for a few days. This meant having to provide for oneself in the most primitive way, for I was short of some of the most necessary provisions and supplies. But in such conditions the decision was not difficult to take. I shall not easily forget the days I spent there.

The plateau of the volcanic lakes Naiwasha, Elmenteita and Nakuro, standing nearly 6,000 feet above the sea, presents to the spectator all the austere, stern, and strange charm peculiar to the Masai uplands.

Some ten years have gone by since that expedition of mine, and all is now changed. $U_{p}$ to that time only the natives had lived in these districts. Few Europeans had penetrated into these solitudes; but now a track of iron rails links the Indian Ocean with the Central African lake basin, and the shrill whistle of the locomotive sounds in the equatorial wilderness. Wherever the influence of the railway extends, the Masai, whom I then learned to know, have disappeared. Reservations have been assigned to them, like the Indians of North America.

My former companion on my travels, Alfred Kaiser, describes, not without a certain feeling of sadness, how he 

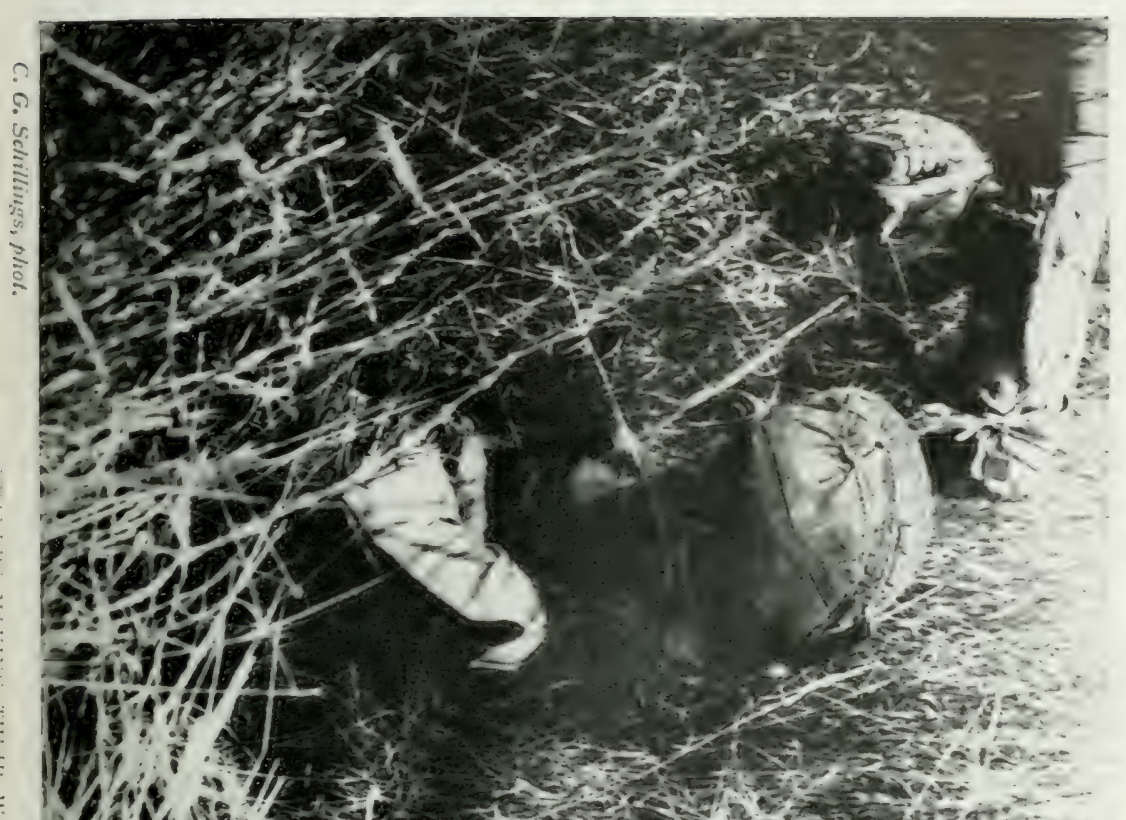

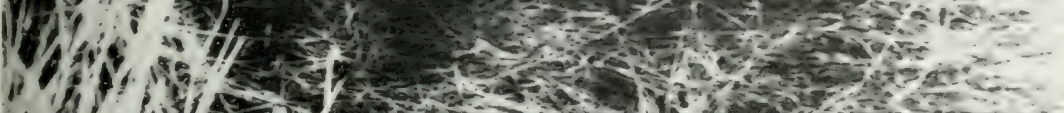

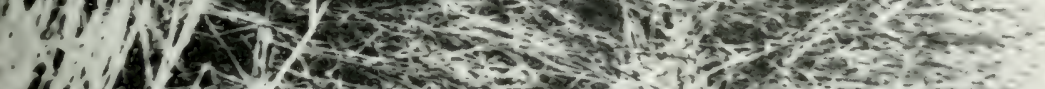

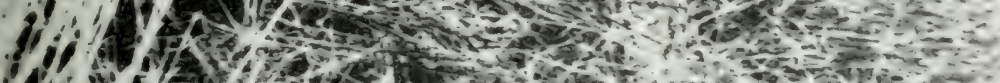

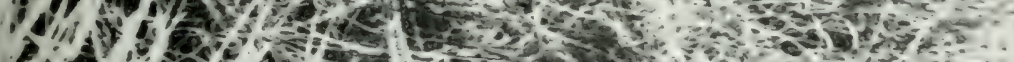

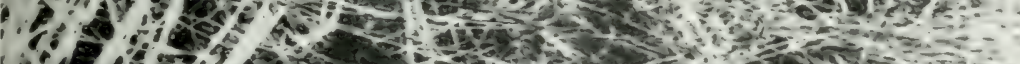

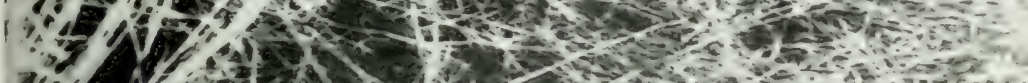

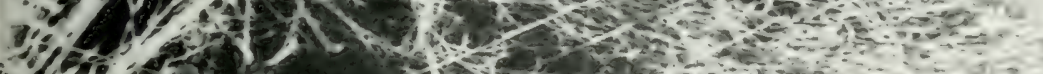

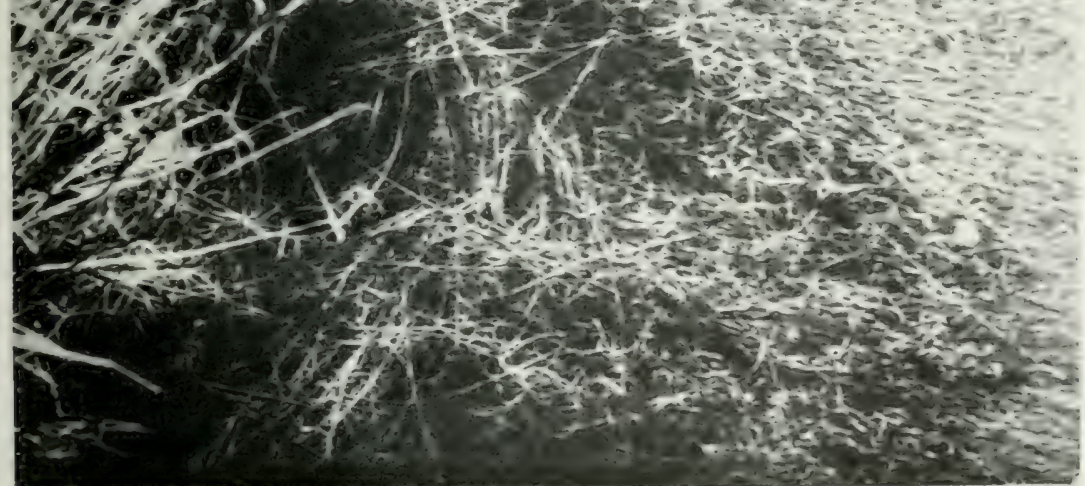



saw them once more, not long ago, under these new conditions, already to a great extent changed by Europan influence-and changed in a way that was not at all to their advantage. Using, instead of the beautiful Masai dialects, some mangled fragments of English, they scornfully refused objects of barter that were eagerly coveted ten years ago, and insisted on coined money. They no longer wore their native ornaments, but were dressed in European second-hand clothes. In a word they were stripped of all the wild and primitive beauty that had once distinguished them.

It is a hard fate, when a rude aboriginal people is all of a sudden brought into touch with those of a high degree of civilisation.

As the former lord of the land ${ }^{1}$ was deprived of his rights, so the same fate, more or less, befalls the splendid animal world that lends its charm to these solitudes.

But then-ten years ago! I had been given back to life after sharp suffering, and all that I was now allowed to see in such rich abundance spoke to me in a more than ordinarily impressive language, a language that seemed to me to have an enduring charm.

And how clearly must this language have sounded in the times of the primitive past!

${ }^{1}$ As late as the year 1859 the Masai warriors menaced the places on the coast between Tanga and Mombassa! Even in the eightics the explorers Thomson and Fischer had to submit to their demands. 'To that flourishing period of the Nasai belongs the origin of their view that even if the Bantu Negro races have cattle, they must have been stolen from the Masai, for, as they say, "God gave us in earlier days all the cattle on the face of the earth." 
So we may here attempt a picture of the wild life of the lake margin in former clays, on the lines of the sketches I have already traced out of the life and activity of the wild herds of the plateau, as I still could see them.

Out of the many memories of those days, that still work on me like magic, there is one above all that has a special meaning for me: "Elelescho!"

But what is "Elelescho"? the reader will ask. "Elelescho" "is the name of a peculiar plant, perhaps it would be more correct to say a bush, that has in many ways set its mark on the flora in the very heart of the Nasai region. Ranges of hills covered with silvery-leafed Elelescho, the spicy smell of Elelescho, the water at the camping place redolent of Elelescho-and also, in consequence. tea, coffee, cocoa tasting of Elelescho-that is a memory that remains fixed firmly in one's thoughts of this home of the wild herds and of the Masai. It was these disappearing nomads who gave the bush its beautiful name.

Possibly the musical sound of the name has not a little to do with reconciling us in memory to the plant. For the bush itself has in process of time a monotonous effect not very pleasing to the senses, but for this very reason all the stronger and more enduring. Its character is connected by strong links of memory with our experiences of those days, and the sound of its name awakes rose-coloured recollections. For just as it is not given to man to remember exactly the nature of intense bodily pains, so fancy, looking backwards, kindly blots out much that was hard and little that was pleasant in the life we

${ }^{1}$ According to Hollis, the singular of the word is "O-1-leleshwa," 


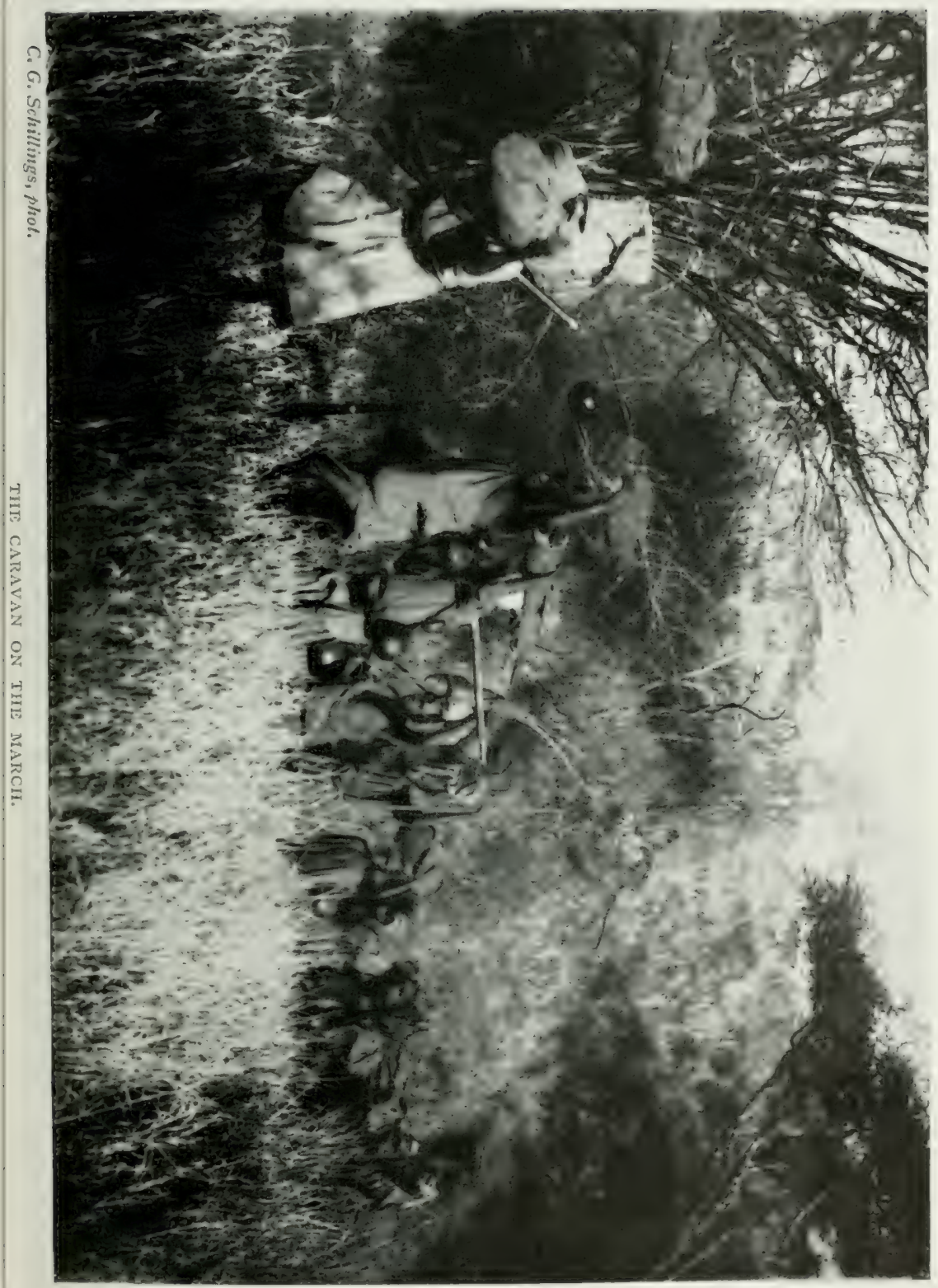

$\therefore \rightarrow$ 

have led. Thus it is that this strange bush, with its silver-grey leaves and aromatic odour, is capable, as hardly anything else is, of awakening in the mind of the traveller a kind of nostalgia-nostalgia for the wilderness, to which he is drawn by so much of beauty and of hardship. We have gained very little by learning that botanists recognise our plant as one of the Compositex, and name it Tarchonantus camphoratus, L. It is to be found also in other parts of Africa; and Professor Fritsch reported, as early as $186_{3}$, that he found it growing in Griqualand, then still an unsettled country, where it was called the "Mohatla." It would be a pity if its beautifully sounding Masai name were not preserved for future times, and I must do my best to save "Elelescho" from such oblivion.

One must have learned the word with its. sweetsounding pronunciation from the lips of a proud, handsome, slender Masai warrior in order to understand how so seemingly slight a thing can imbue one's impression of a whole land.

The Elelescho is as prominent in those regions as the oak and beech or fir in Germany, or as the juniper, the heath, and the broom, and has the same influence on the landscape. But it has a greater and deeper influence upon the imagination, because it so dominates those solitudes, that to him who has long travelled in them the mere memory of it evokes a vivid picture of their once familiar aspect. The strong scent of the Elelescho plant leads the Masai to wear the leaves of the bush as a decoration round their ears for the sake of its perfume. It belongs thus to the plants that because 


\section{In Wildest Africa}

of their scent are used as ornaments by warriors and maidens : "Il-käk ooitaa 'l muran oo 'n__- doiye 'I orôpili." ". So there pass before us Masai maidens and Masai warriors deched with Elelescho leaves and Elelescho branches, and received with sympathetic smiles by the caravan leaders-who, however, unlike the Masai, think very little of it. Very simple and naive are the relations of these natives with nature around them. Only the obvious, the actually useful, comes into their thoughts, and for my black companions the Elelescho always recalls only memories of poor desert recrions of the waste-regions in which they must often endure hunger and suffer many hardships. Far different is the influence of the Elelescho region on my feelings. For me this bush is symbolically linked with the plunge into uninhabited solitudes, with self-liberation from the pressure of the civilisation of modern men and all its haste and hurry.

We wish to feel once more, and to give ourselves up fully to, the spell of the Elelescho--the charm of the Elelescho thickets, that are also in South Africa in the lands about the Cape the characteristic mark of the velt, now so lonely, but once alive with hundreds of thousands of wild herds.

\section{A wonderful night has come on.}

The moon-in a few clays it will be at the full-sheds its beams in glittering splendour over Lake Nakuro.

The little camp is scon wrapped in silence. The weary bearers sink into deep and well-earned slumber. Only the sentries, pushed far out, are on the alert. It ${ }^{1}$ As Hollis tells us. 


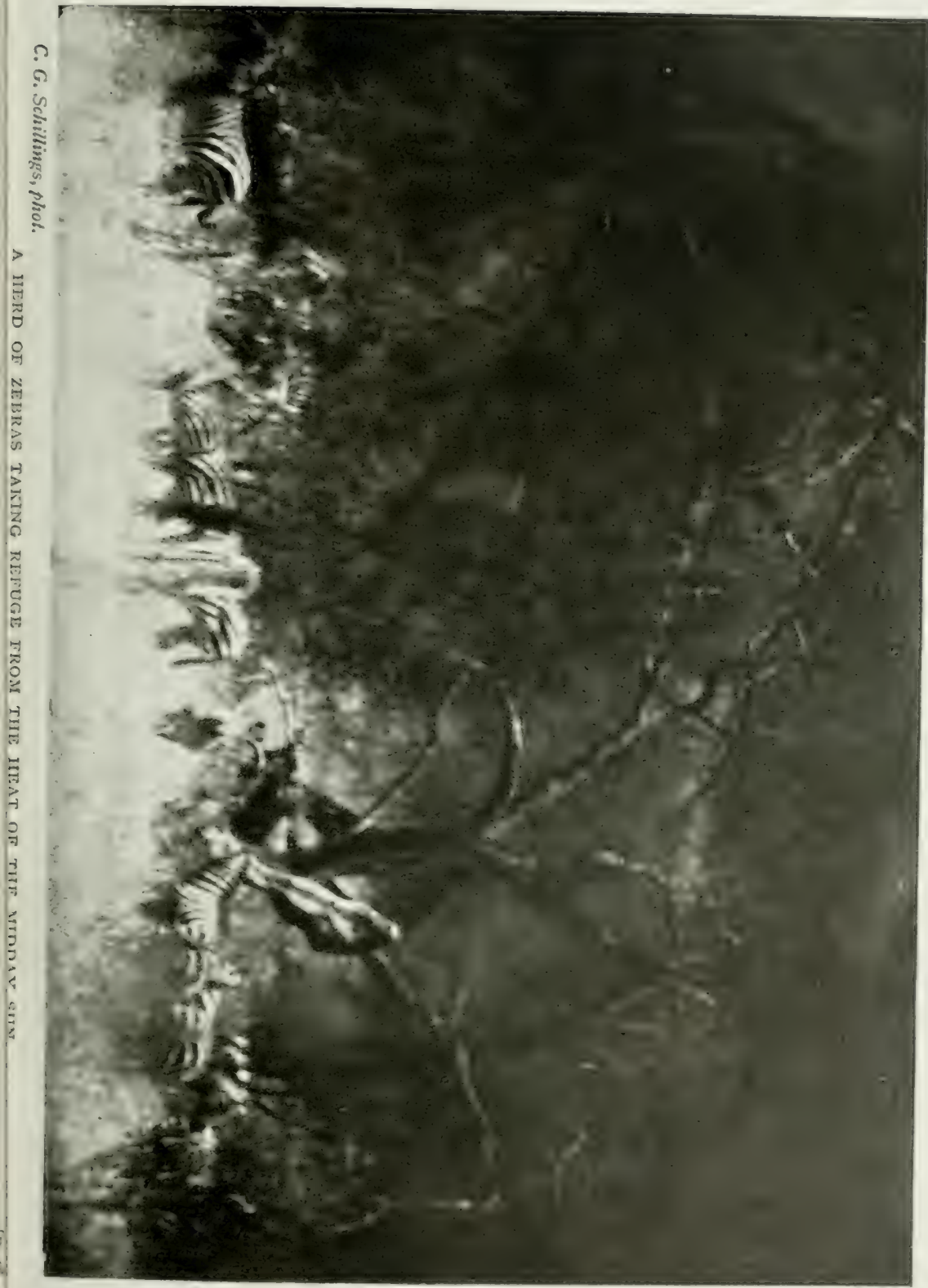





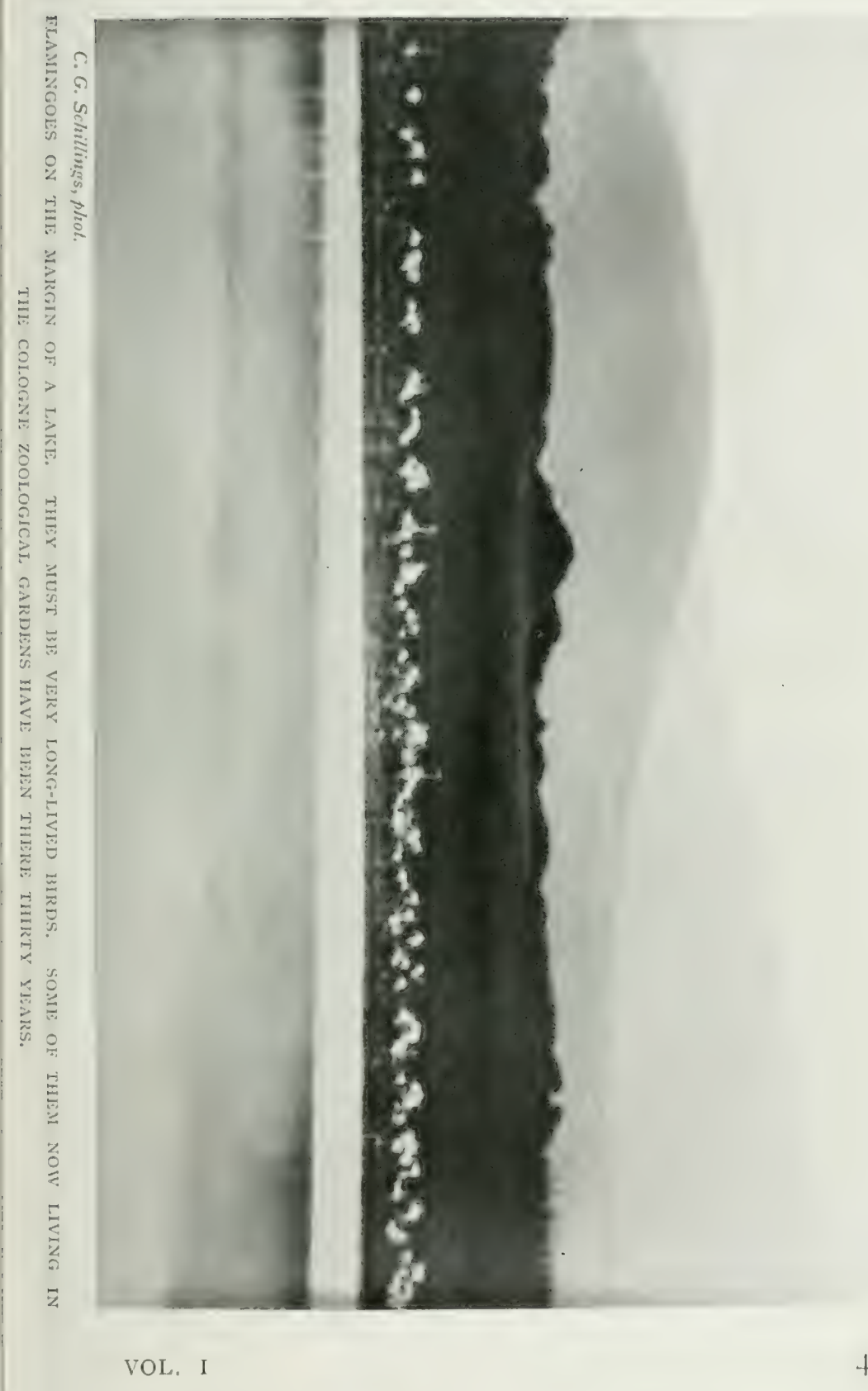



was but a few days since the rebel Wakimassia hillmen were a source of danger to us, and nightly precautions are not yet forgotten. 'The moonbeams flicker ghost-like over the lake. Night-jars give forth their songs close to the camp all round us. Strange sounds and cries ring out from the throats of the waterfowl on the lake margins, and not far away one hears the snorting of the hippopotami. Jackals and spotted hyenas prowl round the camp, betraying themselves by their voices. 'The hyena's howl and jackal's wailing bark mingle strangely with the deep bass note of a bull-hippopotamus. Here in the wilderness there is hardly any sound that is louder than the mighty voice of these giants of the water.

A strange feeling came over me. Amid all the evervarying sensations of the last year my capacity for enjoyment, my sensitiveness to outside impressions, had been developed and enhanced. A short time since I was between life and death, struggling with the treacherous infection of fever. Now I was well. I was breathing the air some three thousand feet higher than the place where I lay ill near Victoria Nyanza. I was again in a region whose vast volcanic solitudes contrasted strongly with its abundance of highly developed organic life, and exercised a strange influence upon me.

Is there such a place as Europe? Is it possible that thousands of miles away there is a centre of civilisation

1 The pachyderms seem to feel no ill effects from the natron-bearing water; but for men the water of the lake - at least, near my camp-proved very unpleasant. Our drinking water was obtained from a small marsh near the shore of the lake. 


\section{In Wildest Africa}

whose teeming millions would fain imprint their image on the whole earth, and even lay covetous hands on this far-off wilderness, and that in time this must happen?

A world of which I myself am a unit! How strange that I can delight so deeply in all this wild charm! And how quickly the wishes of men change! A while ago, in the long nights of fever, I had but one desire-that my heart, my heart alone, should not be buried in a foreign soil, but be taken back to the Fatherland.

And now, only a few weeks after my recovery, how different seems to me all I may hope for from Fate, and how much more complex, how much more difficult to accomplish!

I yield myself up entirely to the spell of the wilderness, to the mood of the night.

That was ten years ago, before the Europeans had banished it - when it ached on the senses like the nocturne of some great tone-poet. But I know well that to-day it is no longer in existence; Lake Nakuro is now only a lake like any other, and the railway whistle wakes its echoes.

That night the spell must have been exceptionally strong. It secmed to me as though I were under some charm, as if I were carried back into the far-off times. There came before my mind much of what the lake had seen in the long vanished past. The lands around me heaved and quaked. Mighty earth-shaping forces were doing their work. I secmed to see before my eyes what happened here in primeval times-how volcanic forces, strange, boundless, and terrible, had built up and given 


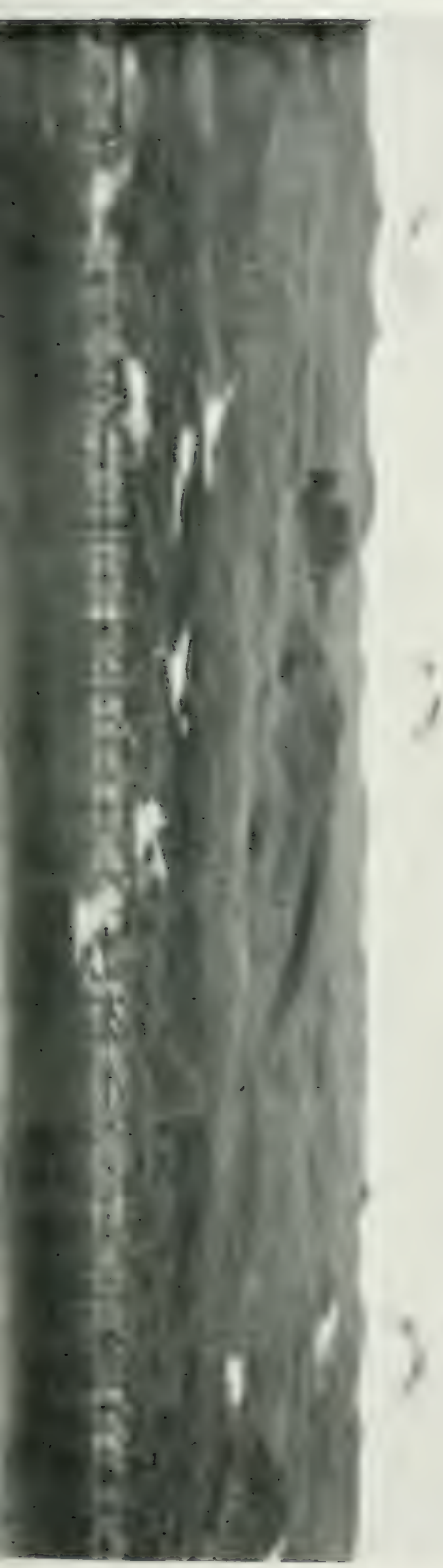



- The Spell of the Elelescho

form to the country around me here, destroying all living

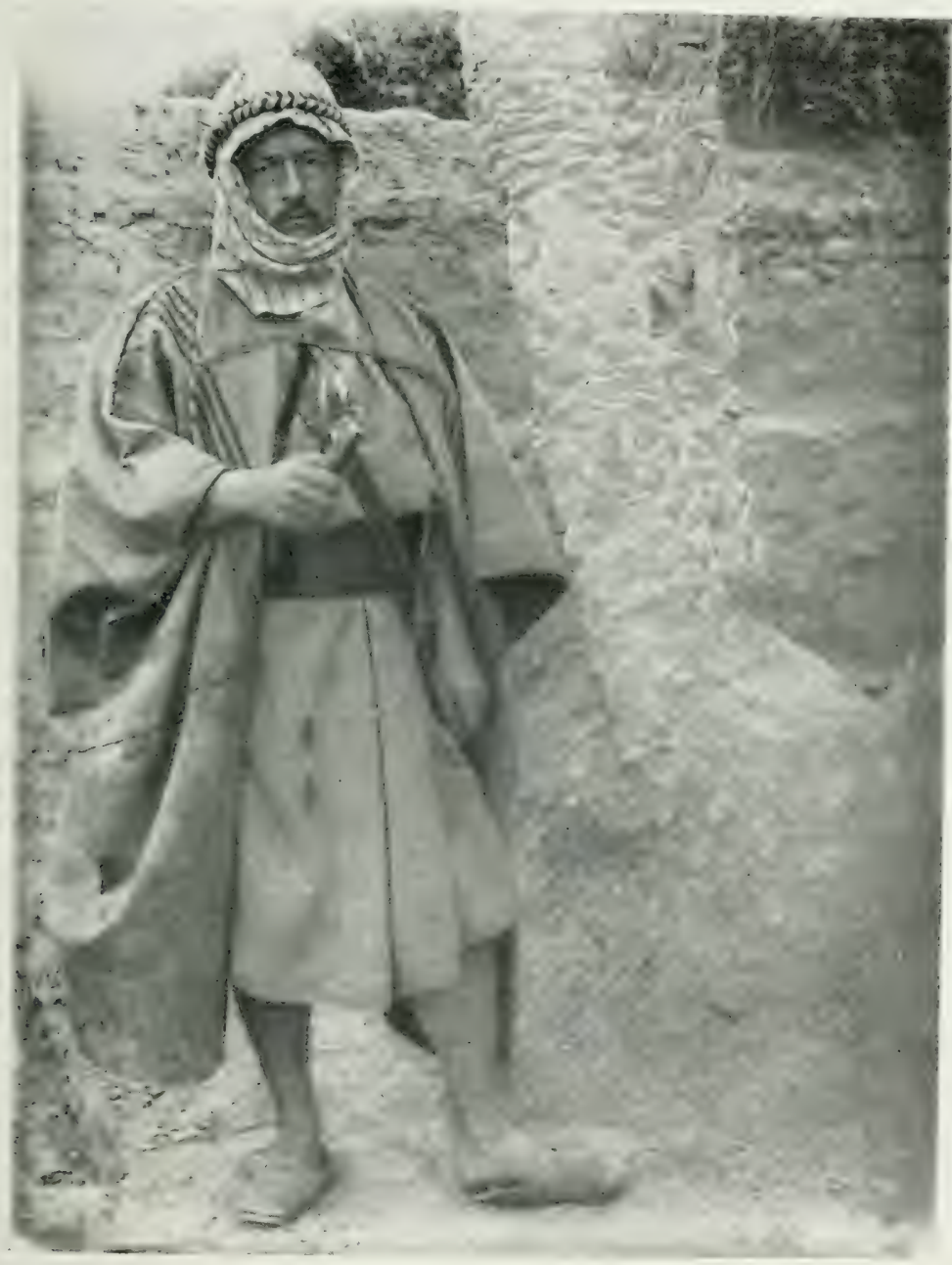

ALFRED KAISER (IN ARAB COSTUME).

things, and yet at the same time preparing the conditions for the hotly pulsating waves of life of later days. In 


\section{In Wildest Africa}

my mind I saw pass before me wondrous mighty forms of the animal world of the past, long since extinct. Then-suddenly I started up. What was that?

A loud trumpeting rang in my ears! Elephants! Were there still extant such herds of elephants as those that I saw coming down there to the lake to drink, rolling themselves in the mud of its banks, and openly making friends with the hippopotami? Just as in the daytime I had noticed the different kinds of antelopes and the zebras, so here I saw again the elephants and hippopotami living their life close together, moving round or beside each other without fear or hesitation. The herd, numbering many hundred heads, was guided to its drinking-place silently and slowly by its aged leader, a female elephant of most exceptional size. Many young elephants were there in company with their mothers. Some very little ones, only a few weeks old, played with their comrades, or knowingly imitated the movements of the older animals in the water, while the old ones took care to prevent the tencler young creatures from taking any harm.

But it all seemed somehow impossible! Veterans among the most experienced black elephant-hunters had assured me that such huge herds were not to be met with. And if I saw aright in the shimmering moonlight, what a great mass of hippopotami were moving about there before me! And now, paying no attention to the elephants that were peacefully bathing farther out in the muddy water, they clambered on to the land, and began to graze like cows on the bank among some more of the elephants. It was exactly the same friendly relation 


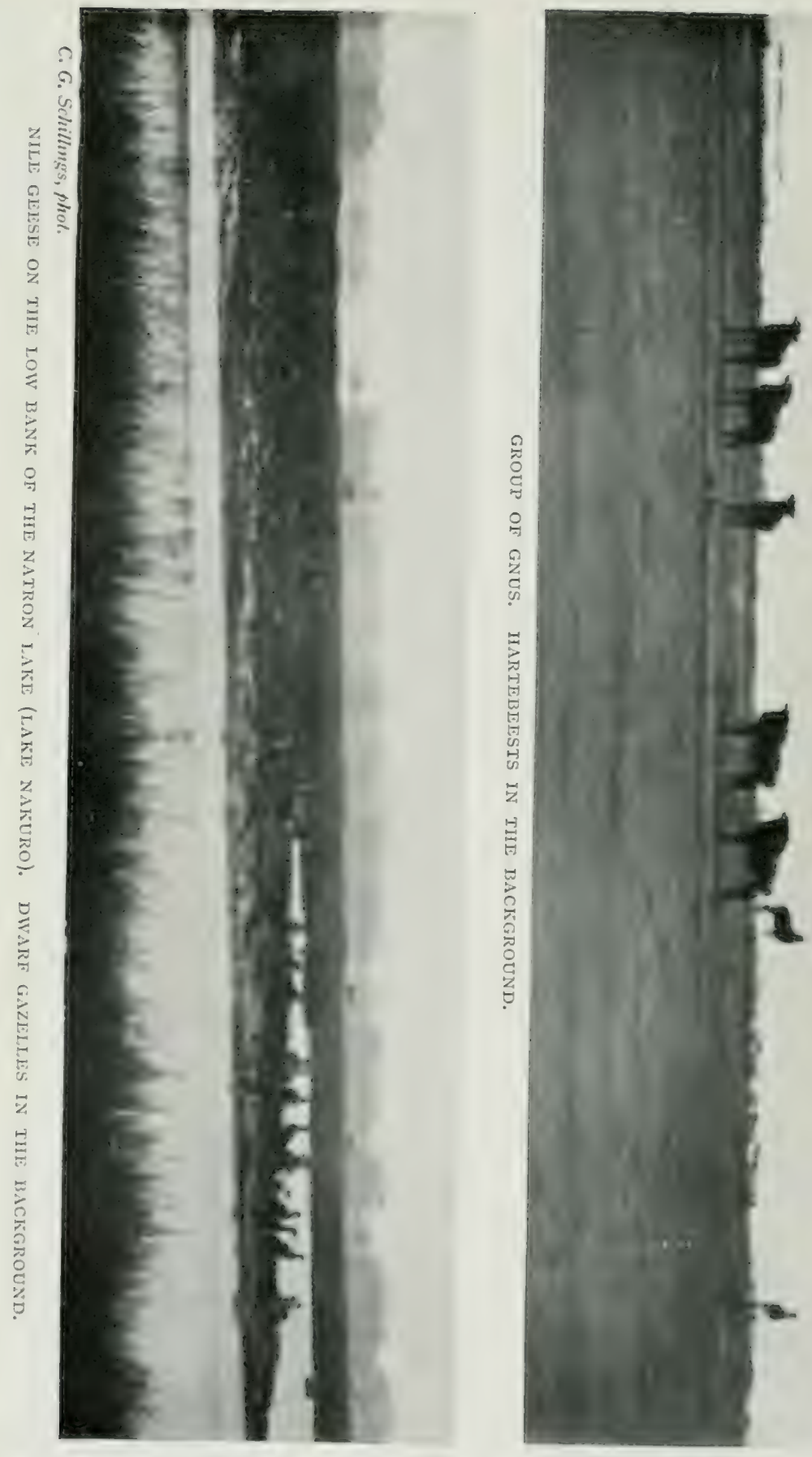

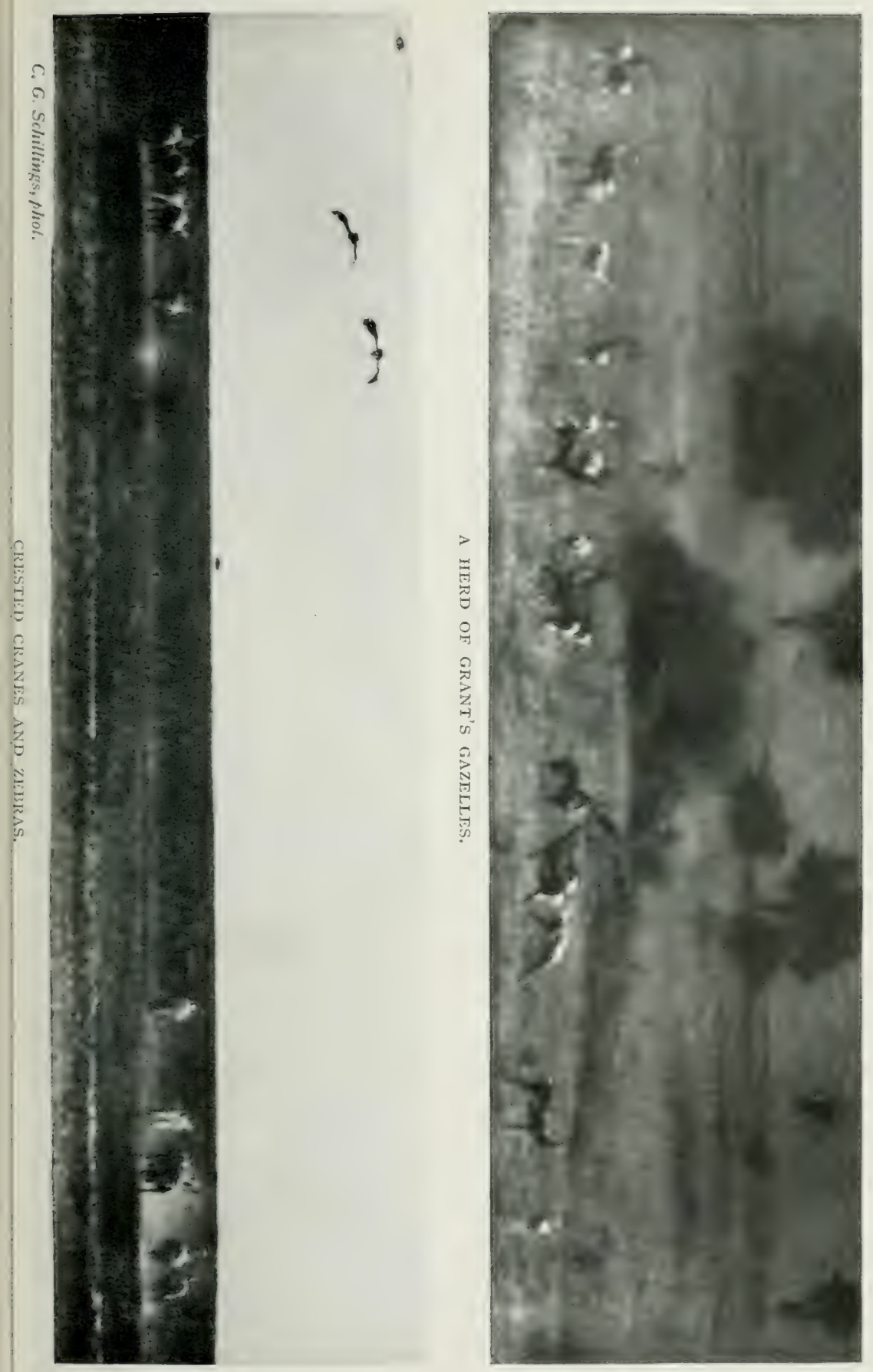



\section{- The Spell of the Elelescho}

that I had seen between the divarf gazelles and the zebras during the day. Could I be only dreaming? Such a multitude of huge creatures here close to my camp-it could hardly be a reality!

And now I perceived that a second herd of elephants, some hundreds strong, was approaching the water. In a straight line these still more giant-like colossi came down to the lake margin-all of them, as I now clearly perceived, bulls with mighty tusks, and amongst them some quite enormous tuskers, obviously patriarchs of the herd, and carrying some hundreds of pounds' weight of ivory that glittered afar in the moonlight.

The two herds greeted each other with their curious cries, difficult to describe, and then the newcomers began to bathe and drink.

My attention was especially arrested by some of the elephants, clearly visible in the moonlight, keeping apart from the rest. Standing together in pairs they caressed each other with their trunks, while the enormous ears which are such an imposing decoration of the African elephant stood out from their heads, so as to make them look larger than ever.

My wonder increases! Numerous herds of giraffes, hundreds strong, come down to the lake, and this, too, not far from the elephants, and without any fear.

And now there is again a new picture! A herd of innumerable buffaloes. With their great formidalle: heatls turned watchfully towards the rest of the crowd, they too are coming for a refreshing bath. Their numbers still increase. It is a sight recalling, surpassing even, the 
descriptions given by the first travellers over the velt regions of Cape Colony.

How did all this accord with the reports 1 had received of the scarcity of elephants? with the destruction of the buffalo by the cattle plague? with my own previous experiences? The most authoritative of my informants had assured me that in this district the elephant was to be found very rarely, the buffalo hardly ever!

Suddenly with mysterious swiftness the night is gone, and the day breaks. I search for and find the tracks of my giant guests of the night. I had made no mistake. Monstrous footprints are sharply impressed in the mud, the ground looks as if it had been ploughed up, and in the midst of the plain, not very far from the lake, there are actually hundreds of mighty elephants standing near some ol-girigiri acacias. As I begin to watch them, they suddenly become restless. In their noiseless way they make off at an extremely quick rate, and soon disappear behind the nearest ridge.

Round about me I see herds of zebras, hartebeests, and wild animals of all kinds in vaster numbers even than those of yesterday. The deep bellow of the wild buffalo breaks upon my ear. I can see long-necked towering giraffes in the acacia thickets. The snorting of numerous hippopotami sounds from the lake. Some of these burly fellows are sunning themselves on its margin; and quite close to them several rhinoceroses are grazing peacefully in the midst of their uncouth cousins.

I am surprised, too, at seeing a troop of lions disappearing into the bush, after having made a visit to the water. 


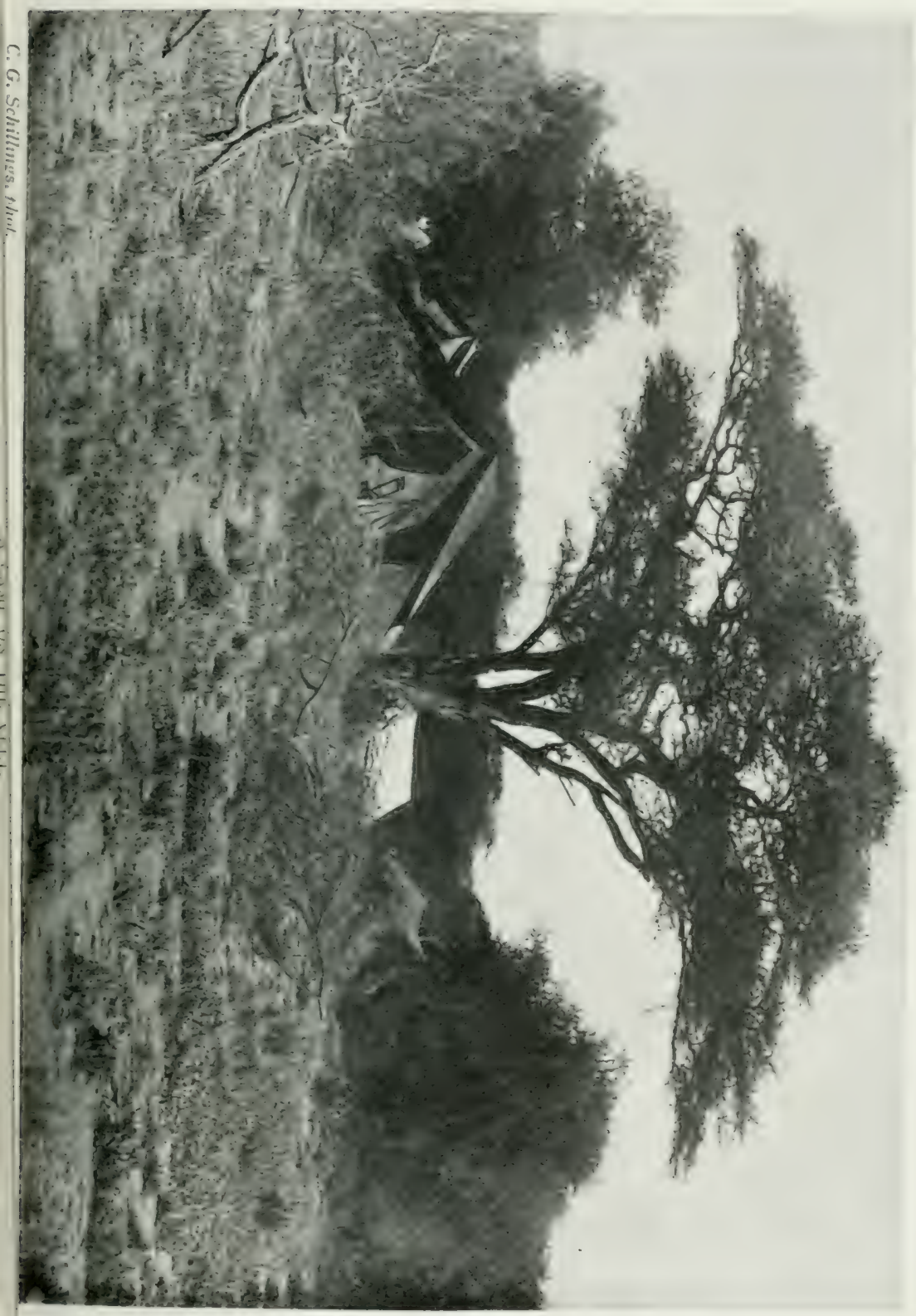



They are so close to me that I can plainly see by the shape of their bodies that they are going home after having had an abundant repast.

The behaviour of my people puzzles me. I had no opportunity for questioning them as to why they were not more impressed by this unexpected spectacle, for my attention was suddenly arrested by the appearance of a lengthy caravan of bearers, that seemed as if it had emerged before my eyes from the trampled ground. There is new life and movement among the herds of wild animals. Slowly, defiantly, or in swift-footed fear, each according to its kind, all these wonderful creatures seek safety from the approaching crowd.

A robust negro marches at the head of the caravan. He carries a white flag inscribed all over with texts from the Koran. Hundreds of bearers come steadily in. Each carries a load of nearly ninety pounds' weight, besides his cooking gear, sleeping-mat, gun and powder-horn. At regular intervals grave-looking, bearded Arabs march among the bearers. Two stately figures, riding upon asses and surrounded by an armed escort, are evidently the chiefs, and a great drove of asses with pack-saddles laden with elephant tusks brings up the rear. Very quickly the numerous party establish their camp, and I now remark that hundreds of the bearers are also laden with ivory. It is clearly a caravan of Arab ivory-traders.

After the usual greetings_- "Sabal kher" ("God bless thee"), and "Salaam aleikum," questions are asked in the Swahili language: "Habari ghani?" ("What news?") I now learn that the party of travellers set out some two years 


\section{In Wildest Africa}

ago from Pangani on the coast to trade for ivory in the Masai country. I an surprised to hear the Arabs tell how, although theirs is one of the first caravans that have made the attempt, they have penetrated far into the inhospitable and perilous lands of the Masai. Their journey has been greatly delayed, for they have had to fight many battles with the Nachenzi, the aborigines of the districts through which they marched. "But Allah was with us, and the Unbelievers had the worst of it! Allah is great, and Mohammed is his prophet!"

Every one set busily to work. In the turn of a hand the camp was surrounded with a thorny zereba hedge, and made secure.

And now I had personal experience of what has passed, times without number, in the broad lands of the Masai; armed detachments from the caravan started on raids for far-off districts. The timid Wandorobo, that strange subject tribe of the Masai, brought more and more ivory to the camp to sell it to the traders, after long and obstinate bargaining. It was remarkable how clever were the people of the caravan in dealing with these timid wild folk, and how well they knew how to gain their confidence. ${ }^{1}$ This confidence, however, was not made use of in trade and barter for the advantage of the natives. But thanks to the methods and ways of managing the natives, as the traders

1 John Hanning Speke, one of the discoverers of the Victoria Nyanza, has already remarked that the Arabs know well how to manage their slaves, and to tame them like domestic animals; that they are able to entrust them with business matters, and send them out of their own dominions into foreign countries, without the slaves ever altempting to escape from their masters. 

understood them, we saw that the wild folk were quite satisfied, and this was the main point.

But what patience is required in trade of this kind! A white man could never develop such Oriental patience. Again and again a tusk would be endléssly bargained over, till at last, often after days of chaffering, it passed into the possession of the caravan. The natives were of course bent on getting the tusks, sooner or later, into the camp. At the very outset they had sent in a most exact description of them, and then envoys from the caravan had to go and inspect them, often at a distance of several days' march from the camp.

Every day a great number of Masai warriors appeared in the camp. Men belonging to many kraals, owners of great herds of cattle, camped near the lake. There were not infrequent skirmishes, especially at night time. The young warriors, the Moran, made attempts at plunder, and were beaten off with broken heads. But, on the whole, this hardly disturbed the good understanding. "It is their testuri (custom)," thought the experienced and fatalistic coast folk, and they accepted it as an unavoidable incident of the trade. But festivals were also arranged, with dance and song. In the still moonlit nights the strange chant rang out in a high treble far over the plain, and sounded in the rocky hills, and festivity and rejoicing reigned among the warriors, the girls, and the women.

But by day one saw their busy life displayed, all the bucolic poetry of grazing herds of cattle with their speararmed herdsmen. There was a great deal to be done, and in each and every task the Masai girls and women showed 
themselves, like the men, excellent guardians and attendants of their herds.

In the neighbourhood of the Masai kraals the wild animals of the plain mingled freely with the tame cattle of the Masai, knowing well that the Masai folk would not shoot them. The wild animals were exposed only to the attacks of the Wandorobo. But these latter bore themselves very shyly in the presence of their over-lords, the Nasai, and went off to far distant hunting grounds, so that the wild animals were hardly ever disturbed by a hunter.

The young Masai warriors also began to devote themselves to hunting for ivory. With great courage, and often with no small display of dexterity, they killed a large number of elephants, allured by the high prices offered by the caravans. But they kept the beautiful tusks carefully hidden, buried in the earth till the moment when they had successfully arranged a sale. The buried treasure was easy to conceal. At the place where the tusks were put away the grass was set on fire and burned up over a considerable area, and then no eye could distinguish the slightest indication of the buried treasure.

The Elmoran also made use of a method of hunting which is employed in other parts of Africa, namely, to slip quietly up to an elephant, and with a single powerfully delivered sword-cut sever the tendon Achilles. But few indeed were daring enough to attempt this, and these were strong, brave, and well-trained warriors. Such an exploit won for them high respect among their comrades of the clan. 



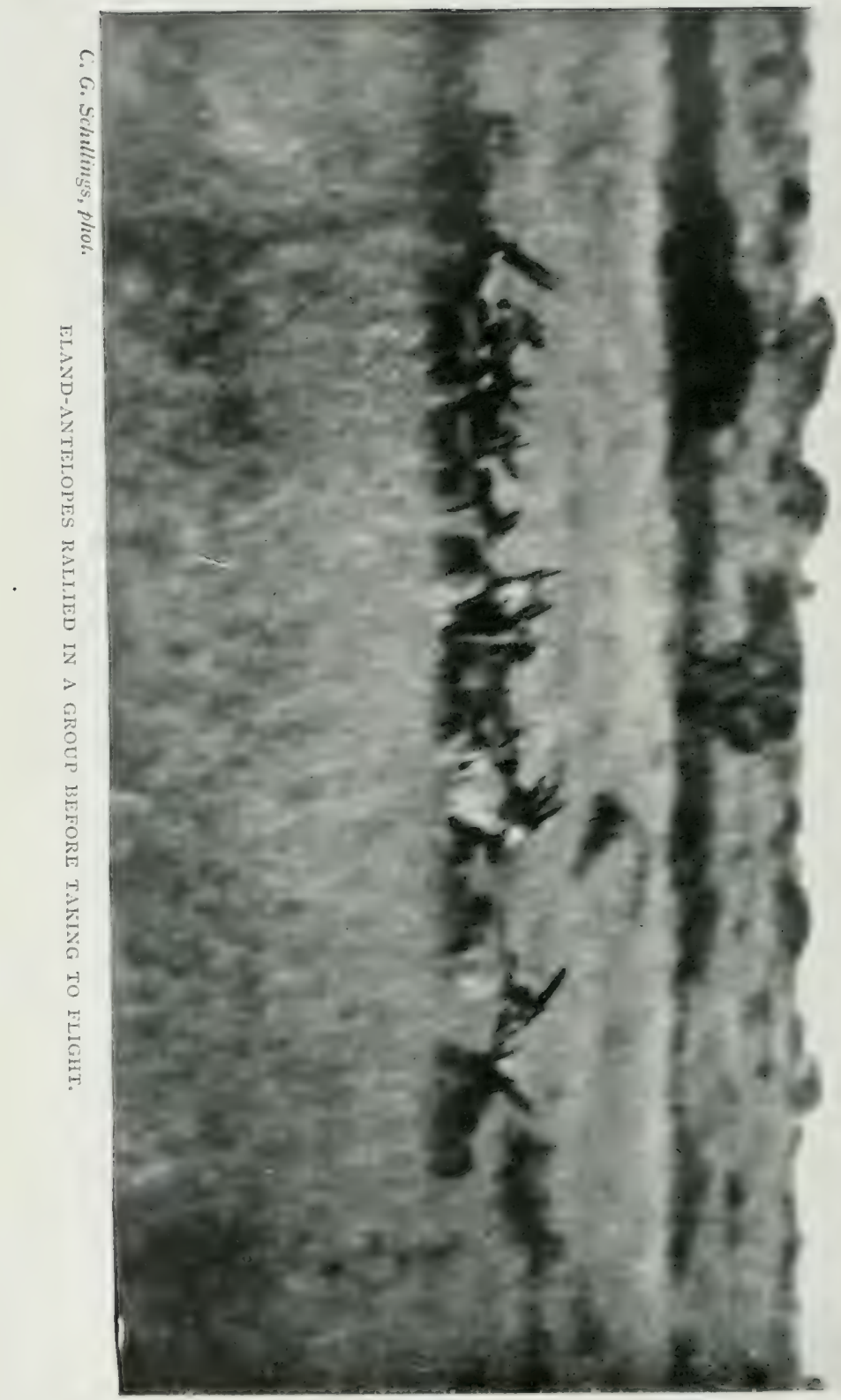




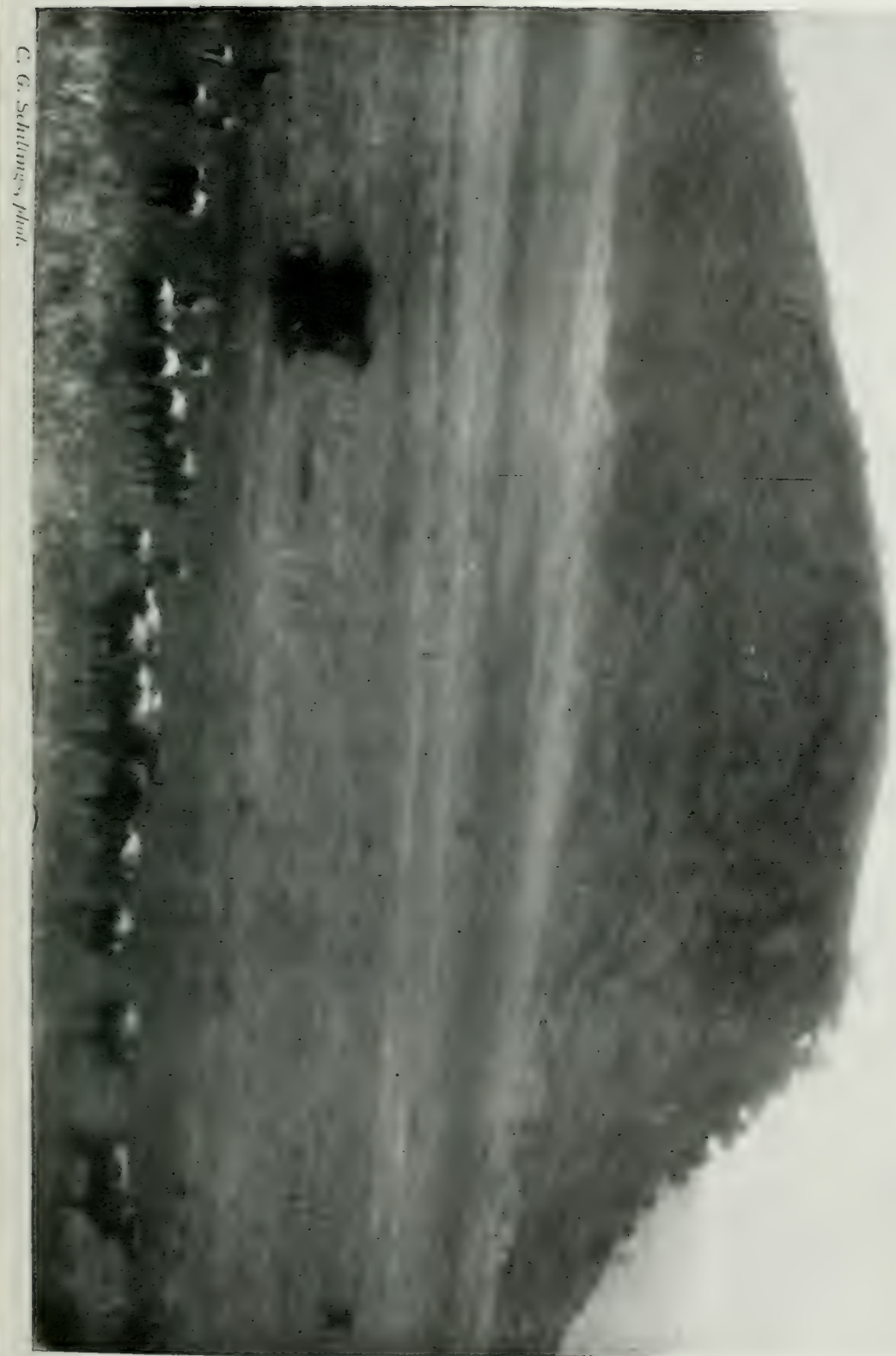



While the Masai warriors thus took their share in elephant-killing, and the Wandorobo stuck to their long, trusted poisoned darts and poisoned spears, the caravan folk attacked the elephants with powder and iron bullets, ${ }^{1}$ and slew whole hecatombs of them.

"Nowadays," the leader of the caravan told me, "the chase is easier and less dangerous, and your firearms also give the man from the coast the power of hunting and killing the Fihl (elephant). For example, you know, sir, that my half-brother, Seliman bin Omari, is not a practised hunter. And yet, believe mie, he and his people have brought down many, many elephants."

But his banker on the coast, the Hindoo Radda Damja, certainly never hears one word of any elephant being killed by Seliman's people:

"No one is so clever as he is at knowing nothing about elephants when questions are asked. The ivory is always something traded for with the natives, far, far away in the interior," he adds, with a cunning wink. "The main point is that we all get pembe (ivory), and he gets plenty of it! I would like to work the business as he does, but, sir, I am not so clever in preparing amulets, and moreover, I don't know as much as he does of the ways of the elephant.

"But it's a pity that in all parts of the country the ivory is becoming very scarce, so one has to be going always farther into the interior, and one must try to find new ivory districts."

${ }^{1}$ The native elephant-hunters-the "Wakua"--use as a rule several small iron bullets with a heavy charge of gunpowder. 
Thus my Arab informant talked a long time with me. He told me much that was interesting and much that was new to me. He told me of caravans that had been massacred, cut off to the last man by the natives in remote districts: and again of caravans that had been not one or two,-no, as long as six years on the march, that had buried a lot of ivory and gradually got it down to the coast. Time counts for nothing here, for the people - that is to say, those who are not slaves-receive only the one lump sum agreed upon for the journey, no matter how long it lasts. His friends, with caravans mustering many hundreds, had carried hundreds and hundreds of barrels of gunpowder into the interior, they had sought everywhere for new districts abounding in ivory, and the result had been the slaughter of the elephants on all sides. Nevertheless he had not much to tell me of men having enriched themselves by this trade. However, this did not apply to the traders on the coast, who adranced the money. These lent money to the caravan leaders, who went into the interior, at the high rate of interest usual in the East, and thus became rich men. 'They had, of course, also many losses. It happened not seldom that one of their clebtors was "lost" in the interior, which means that he simply did not come back, but chose to pass the rest of his life in exile. And in that case it would be a difficult matter for the creditor to take proceedings against him.

Then my informant told me how many of the elephant hunters still living had been carrying on their business already for a long time before any Europeans whatever thought of making a prolonged stay in the country. He 76 


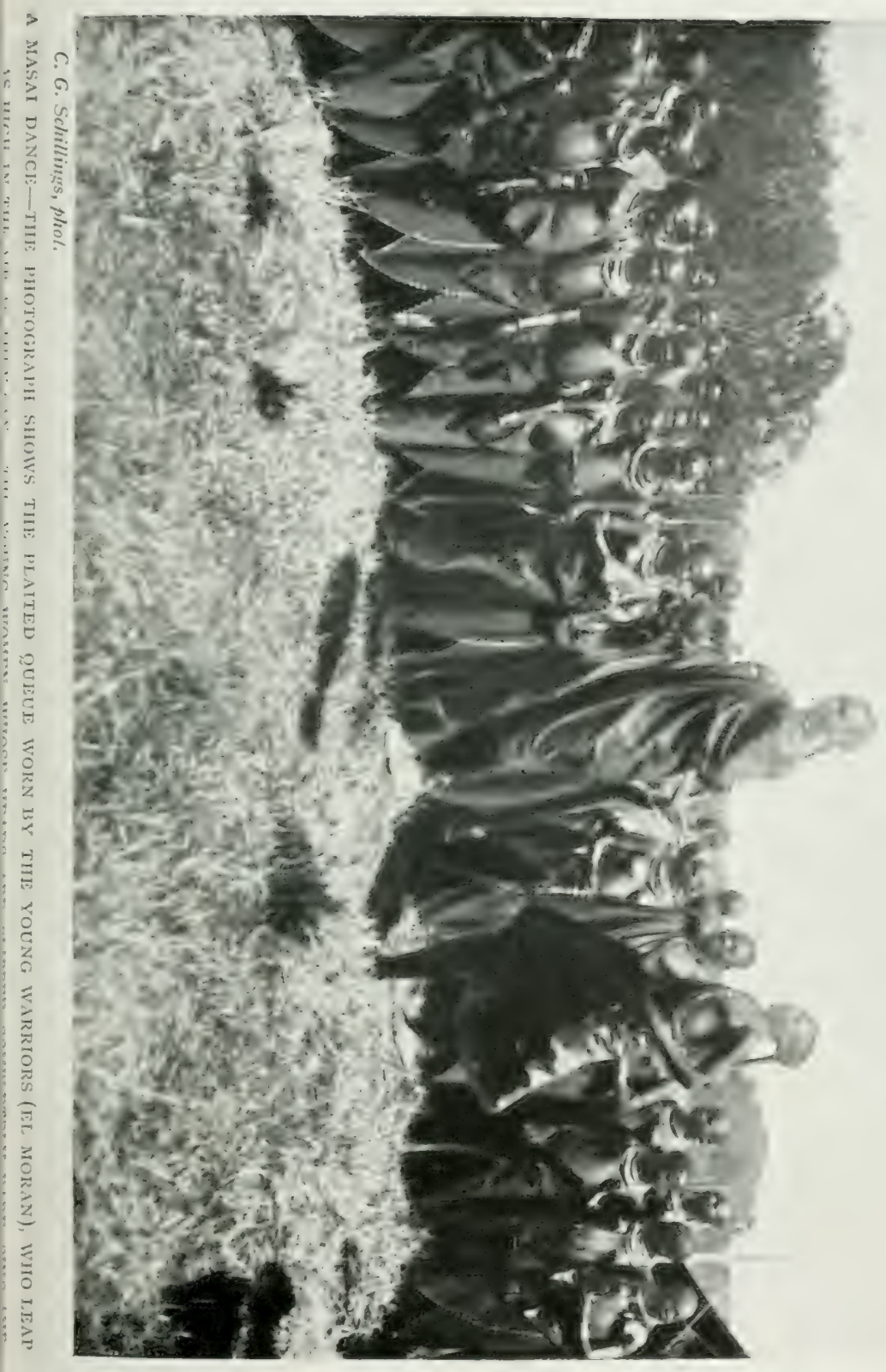



told me also much that was interesting about the old trede routes extending far through Africa, and even to the Congo. He had friends and relatives who had already traversed these routes many times, and journeyed from the east coast even to the Congo, long before any European traveller. Many of the people of his caravan were able to tell from memory each day's journey as far as the Congo, and give exact information about the chiefs who held sway in each district, and the possibility of getting supplies of various kinds of provisions, such as maize, millet, bananas, or other products of the country.

I cannot exactly say how long he had talked with me about elephants and elephant-hunting, about the ivory trade, and many other things. I only know one thingthat after some time his talk became more and more difficult for me to understand, that I strove in vain against an ever-increasing weariness, and that at last I saw neither the Arab nor the caravan - in a word, saw nothing more, felt nothing more.

I fell into a deep sleep in which, in my dreams, I had a lively argument with some Europeans, who would not believe so many elephants, buffaloes, and other wild animals had formerly been here, and who kept on objecting strongly that it was impossible that all this could have been the case so short a time ago.

When I woke up again I found myself in my loungingchair, a primitive piece of furniture of my own construction. My black servant stood before me; and asked me if I would not rather go to bed. 


\section{In Wildest Africa}

I rubbed my eyes-it had all been a dream, then; the spell of Elelescho must have inspired me with it. How foolish to yield to this spell! But men will perhaps so yield to it when all this has become "historical" and the Nasai and their lives and deeds have, like the Redskins of America, found their Fenimore Cooper.

Then may the spell of the Elelescho exert its rightful power; then may it make famous the slender, sinewy, noble Masai ol-morani as, amidst his fair ones, his "doiye," "he leads the song-accompanied dance as he goes out to war: and reigns the free lord of the wilderness! But to-day he bears on his brow the significant mark of an inexorable fate - that of the last of the Mohicans.

The spell of the Elelescho has departed from Lake Nakuro, once so remote from the world.

The lake is no longer remote.

Iron railway lines link it with the Indian Ocean. Vanished from it is the spell that I once felt both waking and sleeping; gone is the poetry of the elephant herds, the Masai the Wandorobo, and the caravan life in all its aspects; gone all that I saw there. The traveller, if he would learn to know the primitive life and ways, whether of men or of the animal world, if he would know the primeval harmony that speaks to him in an overpowering language peculiar to itself, must press on into the wilderness farther away from these tracks. This harmony, whose special character is day by day disappearing, day by day is in an ever increasing measure destroyed, cannot be recalled under the new, the coming 1 Singular: en-dito $=$ the young maiden. 



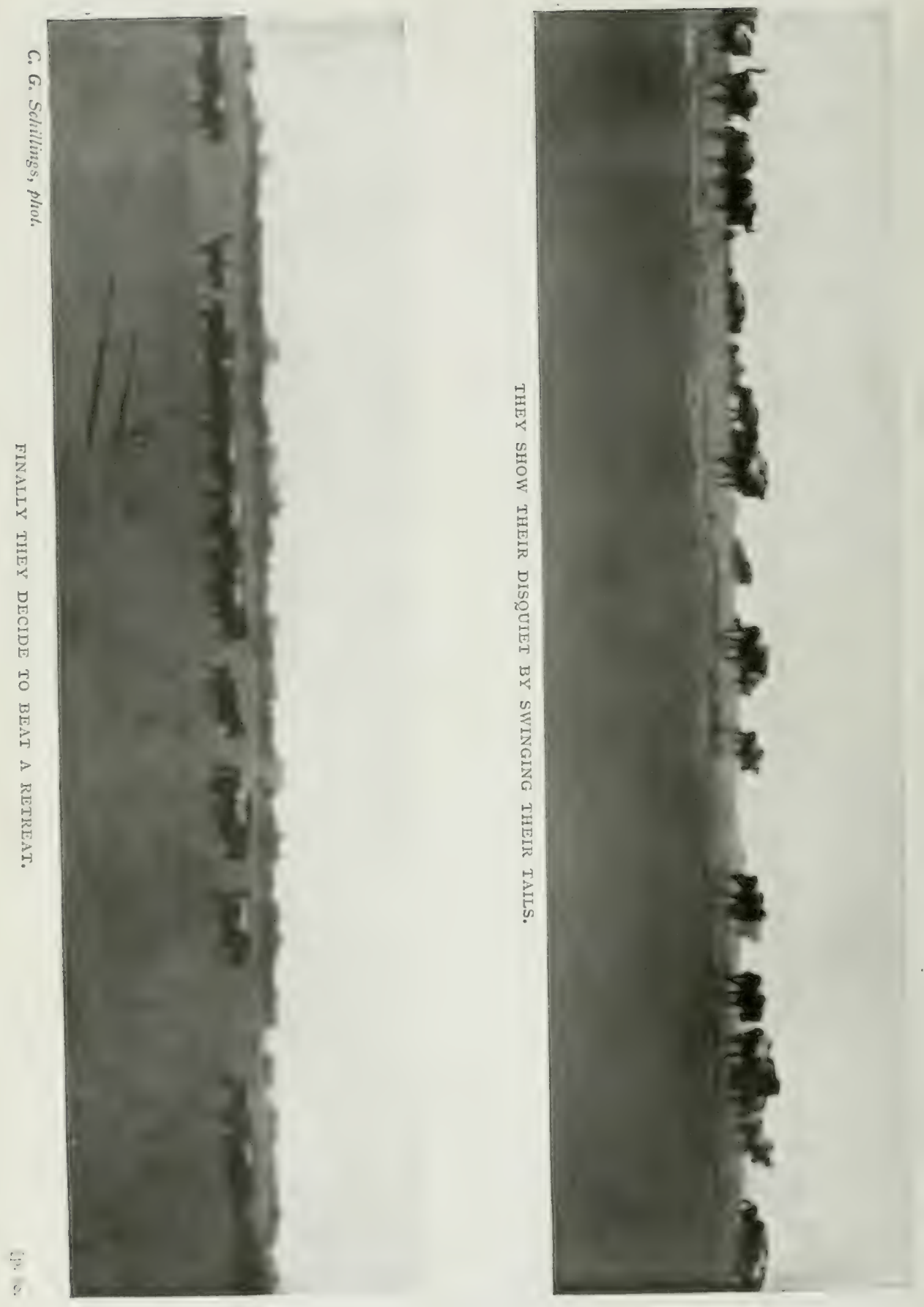



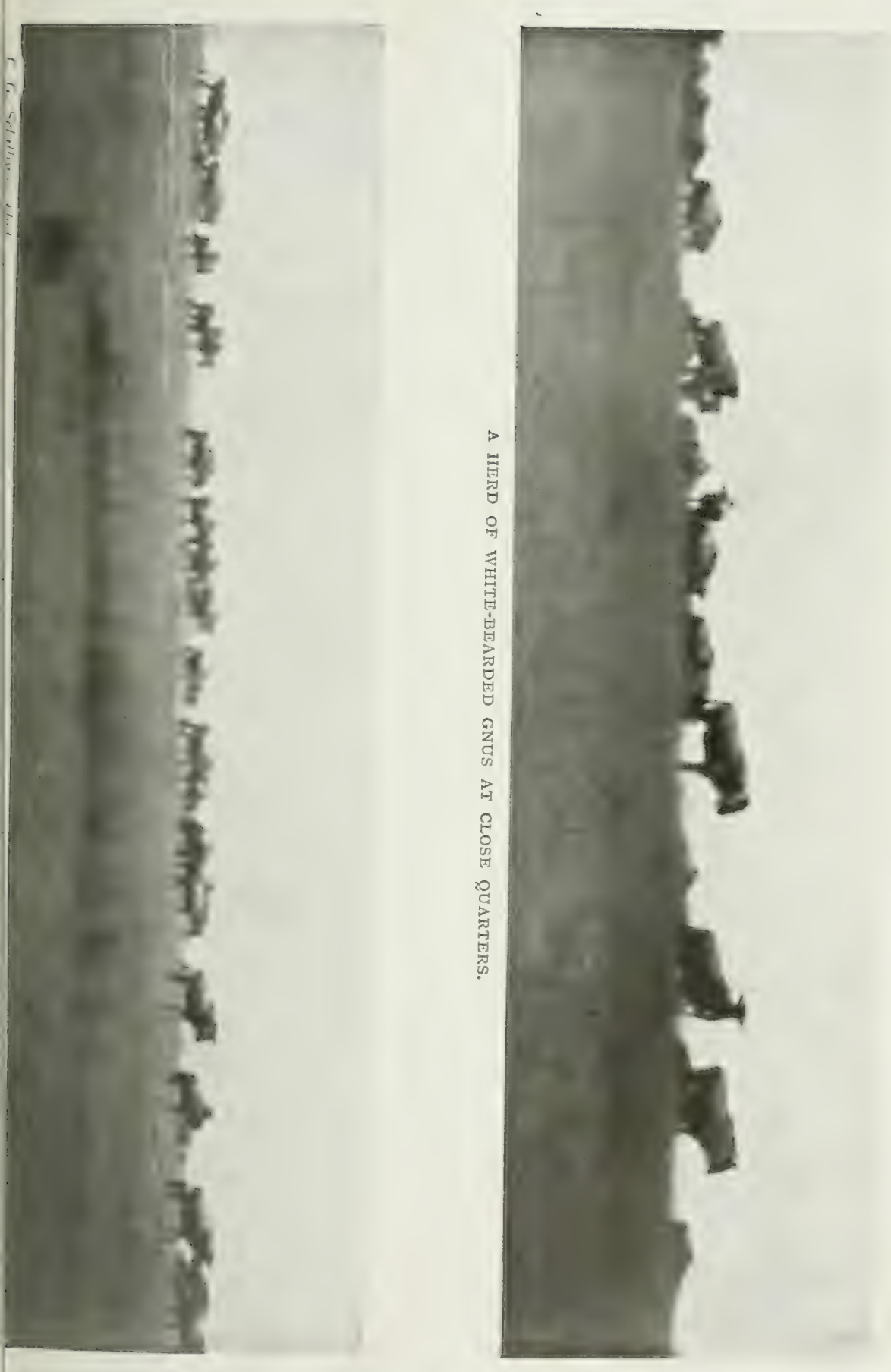



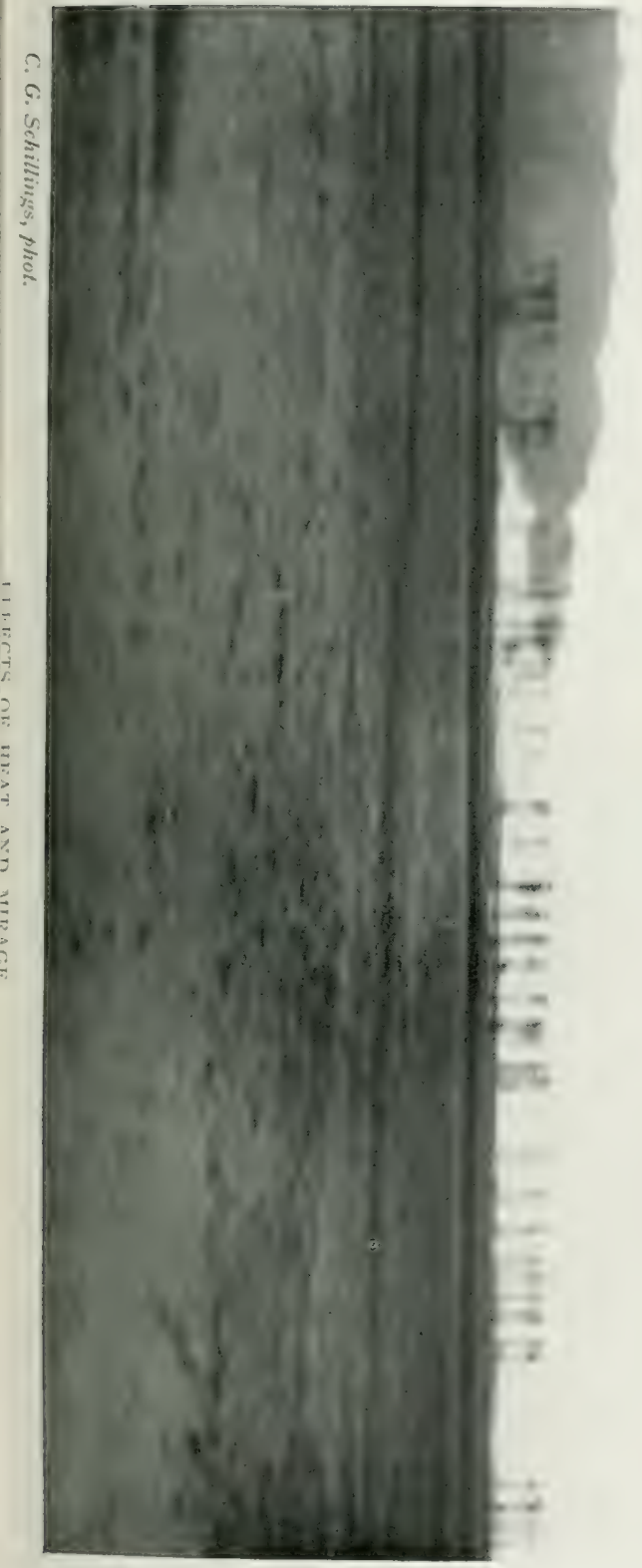

VOL. I 

system, the system that abandons itself to restlessnessthat, in a word, which we call modern inclustry, modern civilisation.

To-day one may perhaps read in the East African Gazette that Mr. Smith, the railway engineer, favcured by extraordinary luck on a hunting expedition, has seen one solitary bull elephant not far from Lake Nakuro! This is something quite out of the ordinary, and Mr. Smith is to be congratulated. Unfortunately his efforts during many years to have even one young East African elephant sent to London have been without any result. A young animal is no longer to be found. In the same number of this newspaper, under another heading, we read the report that the export of ivory this year by the Uganda Railway has been utterly disappointing; the quantity carried has been terribly small, hardly worth mentioning!

I had a talk lately with a travelling companion who had spent some time with me in the wilderness ten years ago, and who had just revisited those distant lands, availing himself of the railway. Alfred Kaiser, a widely travelled man, recalled to me the life we had lived together, when there was yet hardly a trace of European influence among the people of the interior by Lake Victoria. In memory we saw again the inhabitants of then hardly known Sotikoland receiving us mistrustfully on their frontier, thousands strong. Their glittering spears sparkle in the morning sun; chiefs, ministers, and court ladies of the Wakawiróndo appear in camp in most primitive costume; club-armed warriors regard us with the most open distrust ; cowry shells and artificial pearls form their costume and 


\section{In Wildest Africa}

are used as their money; sudden attacks and fighting are quite in the order of the day.

And now, only ten years later, Kaiser has seen the Masai at Lake Nakuro, English-speaking caricatures of civilisation.

A feeling of something like resentment comes upon the traveller who has had to pay toll for his journey with the ceaseless sweat of his brow, when he thinks that now any one can reach Lake Nakuro in a few days from the coast. It is true that the over-anxious globe-trotter is kept in check by only too well justified fears of the treacherous malaria and the sleeping-sickness that has made such terrible progress of late. Otherwise the railway journey from Mombassa to the Victoria Nyanza, and then down the Nile to Cairo, would be a much-travelled route.

I have tried to describe, in brief outline, the rapid, unwelcome change of our time, the result of European civilisation forcing its way in. As I describe things, so they were half a century ago, and even yet ten years ago, when I stayed by the shores of Nakuro, and no railway had yet been made there.

To-day one can no longer find the old spell of the Elelescho there, or anywhere else where the white man has penetrated.

The traveller probably sees only a shrubby plant.

It covers many a ridge, and the lonely plains of the uplands, and sends afar its spicy perfume. The botanists call it Tarchonantus camphoratus, L. They class it among the Compositx. 


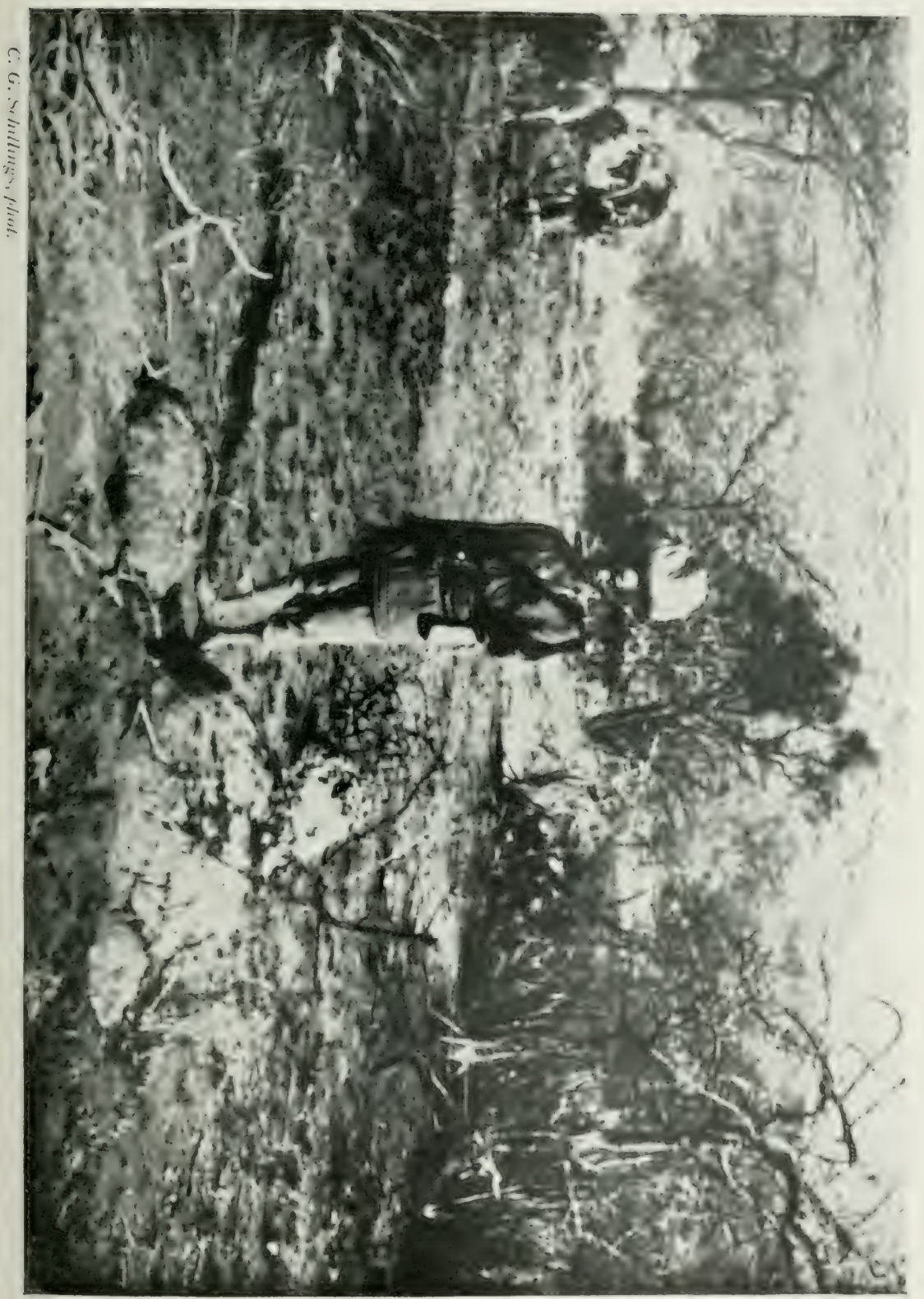



- The Spell of the Elelescho

But here it can no longer exercise any spell.

That has flown far, far away, into the interior. There, where the white man has not yet come, it still prolongs its existence.

How long yet will it be before it has entirely departed?

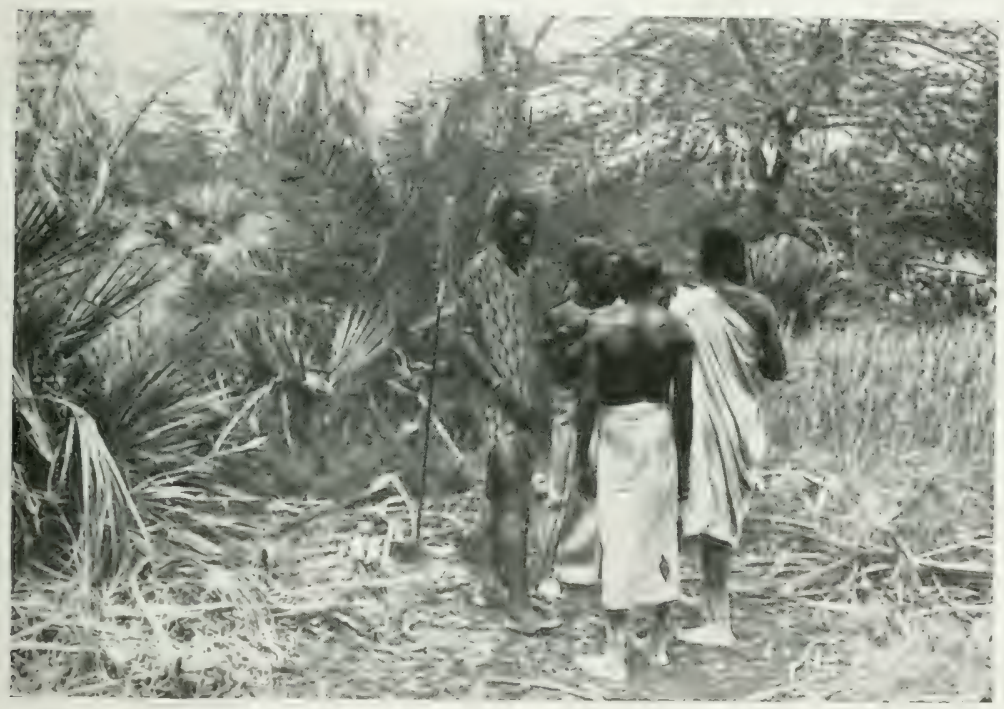

GROUP OF MASAI-THE WARRIOR ON THE LEFT DRESSED IN A COSTUME IMPROVISED OUT OF A COLOURED BED QUILT. 


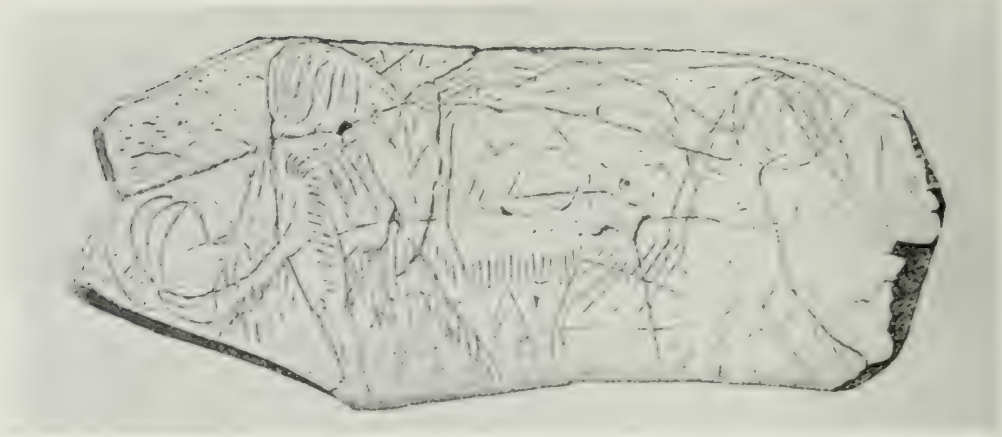

ONE OF THE OLDEST "NATURE DOCUMENTS" FROM THE HAND OF MAN. PREHISTORIC SKETCH OF A MAMMOTH ON A FRAGMENT OF IVORY.

(From L. Reinhardt's work Der Mensch zur Eiszcit in Europa.)

\section{II}

\section{From the Cave-dweller's Sketch to the Flashlight Photograph}

THE mysterious charm of wild nature, undisturbed, 1 almost untouched, by the hand of man, - the charm inherent in all that I have in mind when I talk of "the spell of the Elelescho"-explains the keen and profound interest with which my pictures of animal life were received at home.

In these days, when even electricity has been harnessed by men, there is a feeling that the knell has been sounded of all that is wild, be it man or beast. And however unpretending and inadequate the little pictures might be that I had won from the wilderness, yet all nature-lovers feit that they had here before them authentic, first-hand records revealing secrets which the eye of man had never before looked upon, or had had but scant opportunity for studying. 
- From Cave-dweller's Sketch to Photograph

These pictures were the first to show really wild animals in full freedom, just as they actually live their life on velt and marsh-land, in bush, forest, air, and water. They showed nature in its unalloyed reality, and therefore a peculiar stamp of truth and beauty must have imprinted itself upon them. They came, tou, as a surprise, for in many points the hitherto accepted representations of the animal world and those given by my photographs did not agree.

Nere subject counts for so much in a picture with most people that it takes them a long time to appreciate a work of art the subject of which does not at the first glance appeal to them. This applies peculiarly to my African photographs. It is not a very easy matter for the eye to grasp the movements of the varying forms of animal life in their natural freedom. Often their appearance is so blended with their surroundings that it requires long practice to distinguish the individual characteristics of each, the fleeting graces of their momentary aspects.

I could not, therefore, help feeling a certain apprehension that every one would not at once be able to understand and decipher my pictures in my book, With Flashlight and Rifle. It is necessary when one looks at them to understand, in some degree, how to read between the lines; one must make an effort to grasp their more elusive features; in short, one must devote oneself to the study of them with a certain gusto, a certain intelligence. There was a further difficulty arising from the fact that the illustrations could be reproduced only by a process in which unfortunately much of the finer detail of the originals 


\section{In Vildest Africa}

is lost. The use of the process, however, was necessary for various reasons.

There can be only two ways of securing the best possible result in the execution of pictures of such subjects. The ideal method would be for heaven-sent artists, after years of study, to give us works of this class, and combine in these masterpieces the strictest truth with the finest craftsmanship. But this requires a thorough study of each separate species of animal seen from afar and at close quarters - and how is this possible, seeing that one gets only momentary glimpses? The other method is that of photography, the picture on the negative, which can claim the advantage of documentary accuracy, and at the same time leaves a certain scope for the artistic sense of the operator. So the greatly improved photographic methods of to-day can step in, at least as a substitute and makeshift, in the absence of works of art such as the genius of one man may yet give us. Considering the extreme difficulty of taking portraits of living animals in their wild, timid state, such pictures can only in a few instances lay claim to technical photographic perfection. But at least so far as my own taste goes, a certain lack of sharp definition in the picture (often deliberately sought for in taking other objects) is not only no disadvantage, but is even desirable. As a confirmation of this idea of mine, I may mention the opinion of an American journalist, who declares that my picture of a herd of wild animais given on page 327 of With Flashlight and Rifle to be the most perfect thing of the kind he has seen, and the most pleasing to him, and compares it to the work of a Corot. 
- From Cave-dweller's Sketch to Photograph

It must be noted that if the animals are drawon so as to stand out separated from the landscape which is a needful accessory of the picture, and brought forward into the foreground in an obviously selected pose, they must appear unnatural to the eye of the cxpert. Such pictures cannot fail to give an unnatural impression, for in the freedom

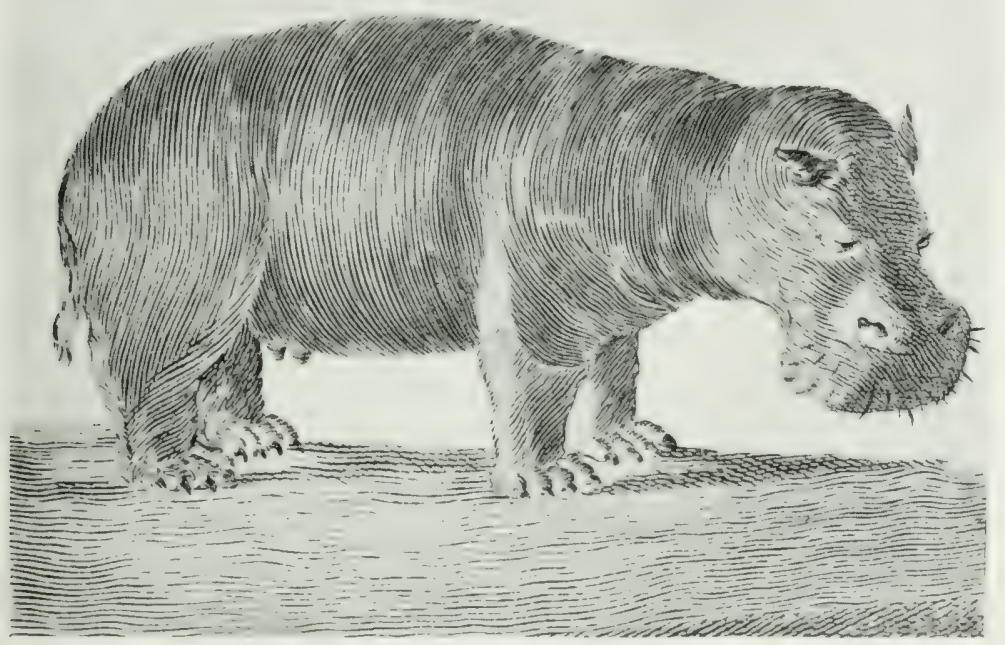

PICTURE OF A FEMALE HIPPOPOTAMUS FROM LE VAILLANT'S BOOK OF TRAVELS, PUBLISHED MORE THAN A HUNDRED YEARS AGO.

of the wilderness the animal world never presents itself in this way to the eyes of man. In their full significance as masterpieces of nature, all the various aspects of the animal world are first manifested to us in close connection with their environment. It has been a keen satisfaction to me to find that many world-renowned artists have appreciated warmly the beauty of these photographs, and 


\section{In Wildest Africa}

have given expression to this feeling. I have been told, for instance-what I myself had already noticed-that numbers of the pictures, especially those showing birds on the wing, bear a great resemblance to certain famous works of Japanese painters ${ }^{1}$ of animal life, works that seem to dive into the secrets of nature. It has been brought home to me, indeed, both by hundreds of letters and thousands of opinions expressed in conversation, that the pictures have excited almost universal interest, and that my labours have not been in vain.

Fully to enjoy the peculiar beauty of such photographs of living wild animals, the best way is undoubtedly to see the pictures considerably magnitied by means of the marric lantern. On account of the special character and strangeness of most of the objects shown, I have the lantern slides lightly tinted. This colouring can be done without in the least altering the picture in its details, and its object is merely to secure greater effectiveness. Approval from all sides, both from artistic circles and from the public, satisfies me as to the correctness of this proceeding. Only in this way do photographic pictures shown by transmitted light produce the full impression of beatuty and naturalness: they seem to transport the spectator directly to the far-off wilderness.

There must be some good reason for the widespread interest manifested in these pictures of the life and ways of animals, some of them still so little known, and all of them living in remote solitudes. It seems to me that the

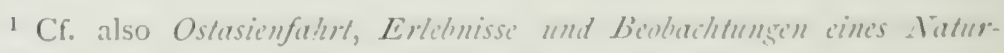
forschers, etc., von I)r. Franz Doflein, Leipzig, 1906.

92 
- From Cave-dweller's Sketch to Photograph

cause is deep-seated-that deep down in the heart of the highly-cultured civilised man there are involuntary yearnings after the sensations of wild, healthy, primeval nature. The progress of mankind from the so-called barbaric stage to the highest civilisation has been accomplished in so short a time, in comparison with the whole period of man's

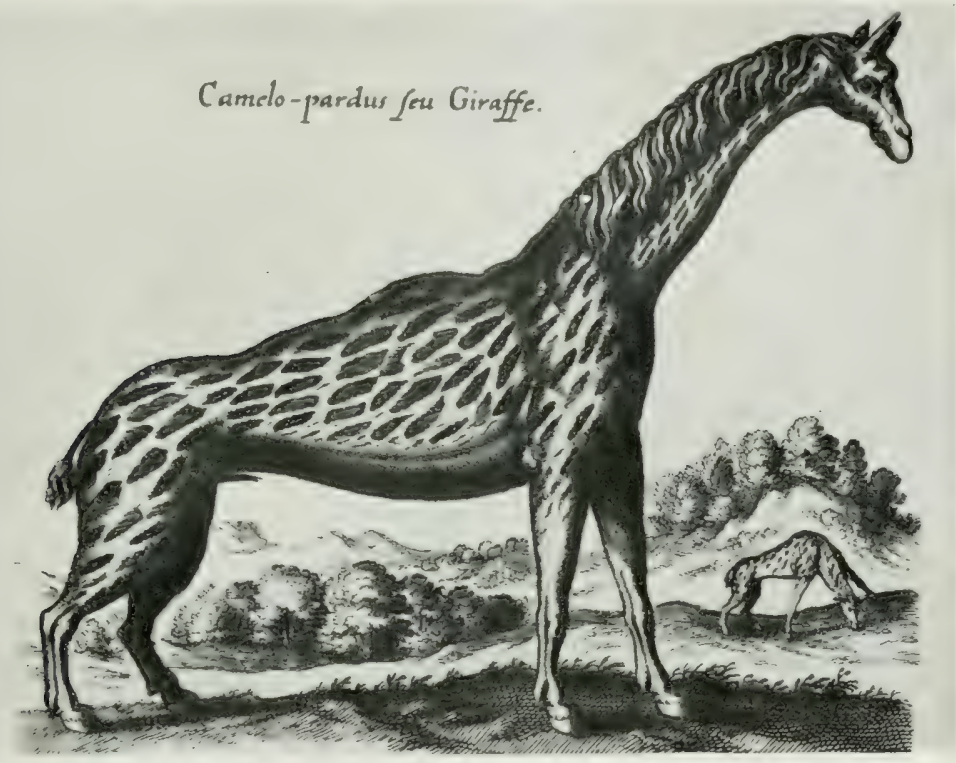

A GERMAN PICTURE OF THE GIRAFFE DATING FROM ABOUT TWO HUNDRED YEARS AGO.

existence, that it is easy to understand how such a longing may survive. In every man there must be something of this craving for light and air and primeval conditions.

"The conflict of man with the animal world," says Wilhelm Bölsche, "has passed away unsung and uncelebrated. The civilised man of to-day has hardly a 


\section{In Wildest Africa}

recollection of the endless lapse of time during which mankind had to struggle with the beasts of the earth for mastery." Let us for a few moments turn our gaze backwards to that far past. In epochs that the learned date back by hundreds of thousands of years, we find attempts made by the cave-dwellers to execute artistic representations of nature as they saw it. The artist of prehistoric times set to work with his rude instruments to draw in merest outline on a smooth rock-face, on a tusk taken in the chase, or on some such material, the things that had particularly attracted his thoughts or stimulated his efforts. Specimens of these primitive works of art have been handed down to us. In the first place there are pictures of animals, scratched upon ivory, and notwithstanding all their crudeness, sketched with sufficient ability to enable us to-day to recognise with certainty the objects which the artist tried to depict. Such sketches scratched on ivory, showing various kinds of animals (some of them now extinct) and forming the oldest documents of the animal-sketcher's art, have been found in the caves of the south-west of France, in the old dwellingplaces of the so-called "Madeleine" hunters of La Madeleine and Laugerie Basse. The museum at Zurich also possesses similar primitive documents from the Kesslerloch cave, near Thaingen, in the canton of Schaffhausen.

It is indeed not surprising that the cave-dweller of those days took his models from the ranks of the animal creation. All his thoughts and efforts were directed to the chase; he had no resources but in this pursuit, and 
- From Cave-dweller's Sketch to Photograpli

he had to carry on, day and night perhaps, a fierce struggle for existence with wild beasts. One can thus follow the development of the human race through the course of time from the primitive sketches of beasts down to our own days, in which it has been reserved for the hand

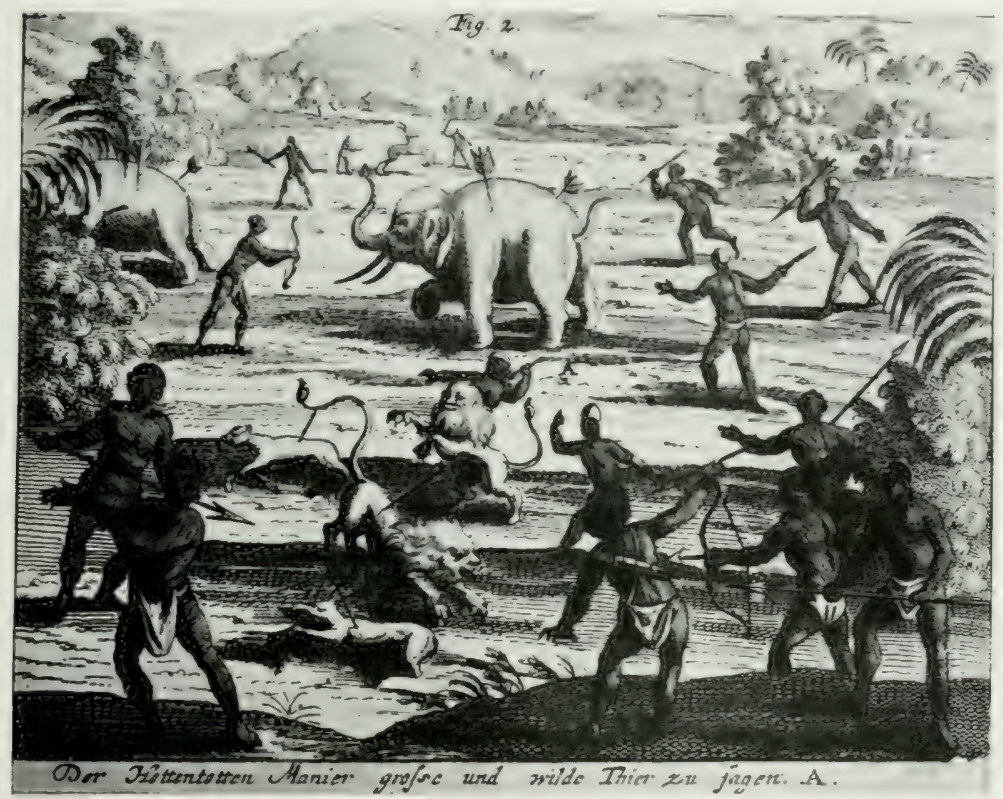

HOTTENTOT HUNTERS-A SKETCH DATING FROM 200 IEARS AGO.

iSome South African tribes actually hunt the lion on foot with javelins, and I have myself more than once observed the courage of the East African natives in similar circumstances.)

of man to execute masterpieces inspired by genius, and in which man makes the sun to serve him in depicting and preserving representations of all that lives and moves, creeps and flies. By means of the sketches of animals laboriously scratched on pieces of ivory by the Care men

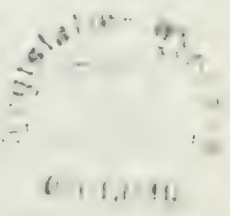




\section{In Wildest Africa}

of Southern Europe, we make the acquaintance of the long-haired prototyles of the living elephants of to-day. These animals were the most coveted big game in Europe. Clearly recognisable sketches of reindeer tell us that a climate like that of the northern steppes prevailed at the time; others of horses show that the wild horse was then to be found in Europe; those of the aurochs prove the existence of that animal. There is a remarkably close resemblance between the style of all these drawings and that of the rude sketches made by the Esquimaux of our own day. Some such Esquimaux sketches of animals on walrus tusks, at the most a hundred years old, are to be found in the Berlin Ethnographical Museum. Interesting, too, are the sketches of giraffes from the hands of ancient Egyptian artists. They show us that the artist of those days in drawing animals allowed a loose rein to his fancy and imagination. Thousands of years must separate these representations of animals from the sketches of Asiatic wild life which Sven Hedin discovered at Togri-sai-Tale near Lôb-nor. They are scratched on bright green slate, and depict yaks, wild asses and tigers, and the hunting of them with bow and arrow. They appear to be of the same kind as the animal-sketches made by the South African Bushmen, discovered by Fritsch in the year $186_{3}$. These cave pictures show us various members of the fauna of Cape Colony, which has already been to so great an extent exterminated. During the period of the Middle Ages a more perfect style of representing animals was gradually evolved, but even about the year 1720 we find representations that are inaccurate to an incredible extent, 96 

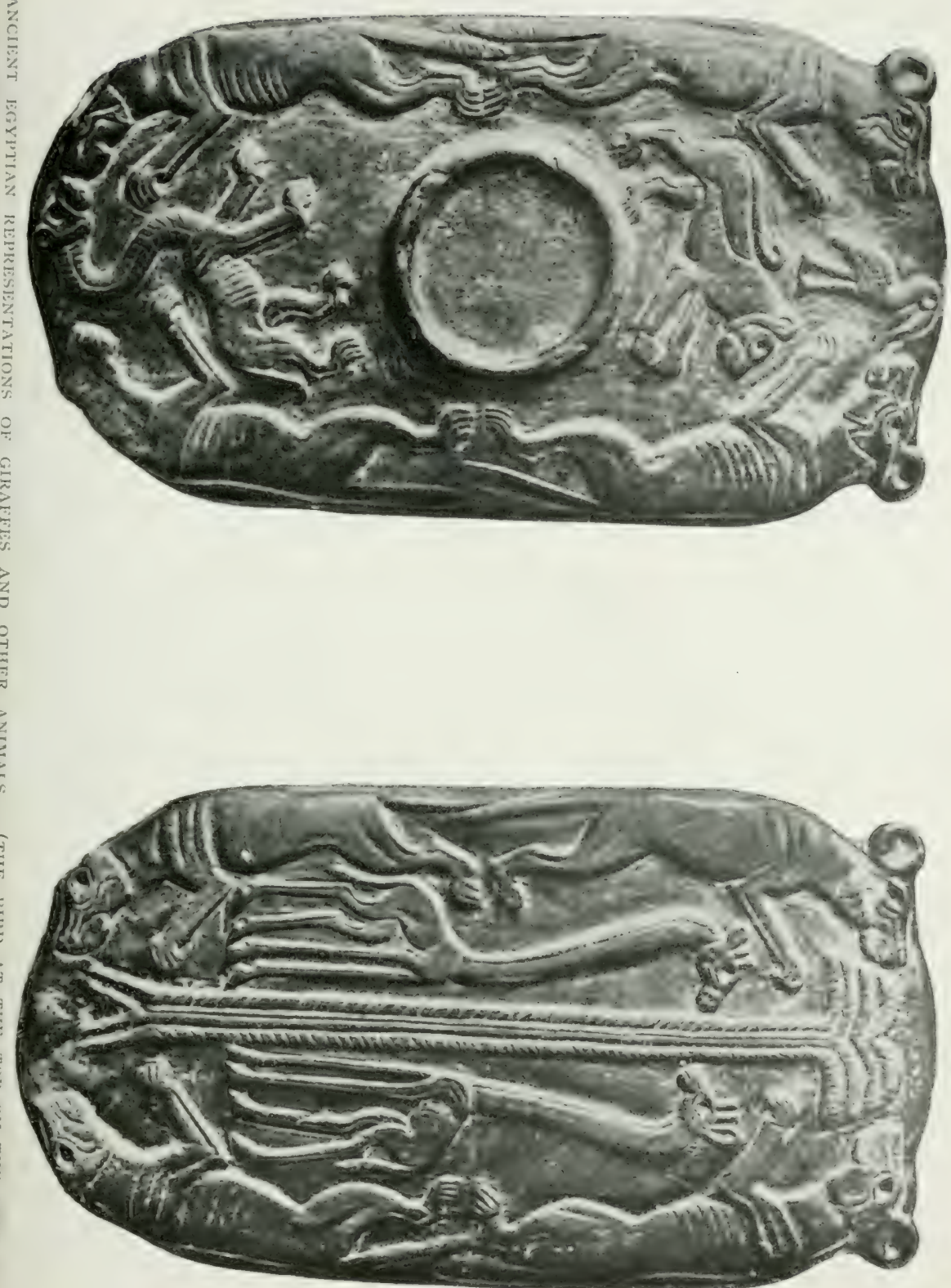

VOL. I 

- From Care-dweller's Sketch to Photograph

and, indeed, so recently as the early part of last century, one sees in the travels of the French naturalist I,e Viillant, in the picture of a female hippopotamus, a proof that the development of animal-drawing had as yet made little progress.

But what a difference in drawing and technique has come about in less than a hundred years! One need only
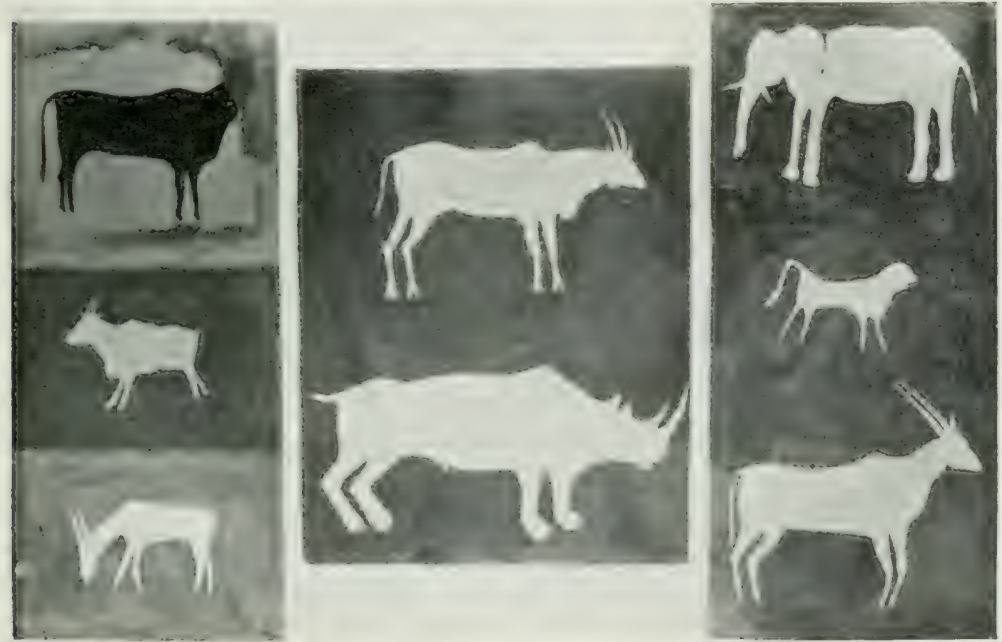

SKETCHES OF ANIMALS MADE BY THE BUSHMEN. (DISCOVERED IN SOUTH AFRICA BY PROFESSOR G. FRITSCH IN THE 'SIXTIES, AND REPRODUCED BY HIS KIND PERMISSION.)

compare the pictures of those times with the works of our own days, to be convinced that, besides artistic execution, there is now an increasingly exacting demand for the precise truth. Indeed, one of the first points to be insisted on is that photographic pictures shall not be altered, worked up-in a word, in any way "retouched." Only on this condition can they really claim to be-that which 
in a special sense they ought to be-true to nature, absolutcly trustworthy" "nature-documents." 'This distinguishes the photograph from works of art executed by the hand of man, which must conform to each individual conception of the artist.

It is a hard saying that the modern cultured man is becoming continually more and more estranged from nature. But in this matter let us take the standpoint of the optimist, who says to himself that there must be a reaction - a conscious, deliberate return, which indeed will represent the result of the highest stage of culture. There is an increasing perception of the existence in our home landscape of an ideal worth, that we have not yet been able sufficiently to estimate. To-day already there is a movement on all sides, and the demand is heard, ever stronger and clearer, for the protection of the beauties of nature. We must protect Nature in the widest sense of the word. And even if, in the stern progress of evolving civilisation, much that remains in the treasury of primitive nature must be destroyed, we shall be able long to preserve and rejoice in much else.

And here come into play the healthy desire of man in his primitive state, the cry for light and air, and all the beauty of nature. It is hardly a hundred years since we in Europe learned to value the landscape beauties of unspoilt nature. English writers of travels a century ago still spoke of Switzerland with aversion; it was for them a horrible, dismal mountain country. And it is easy to understand how man in his hard struggle for the necessaries of life regarded, and was forced to regard, 
- From Cave-dweller's Sketch to Photograph

nature around him as on the whole unfriendly and menacing. But since those times there has been a change for the better, even though it cannot be denied that many men require very specially adjusted spectacles to enable them to enjoy this or that beauty of the nature around them! Thus the landowner feels a pleasing

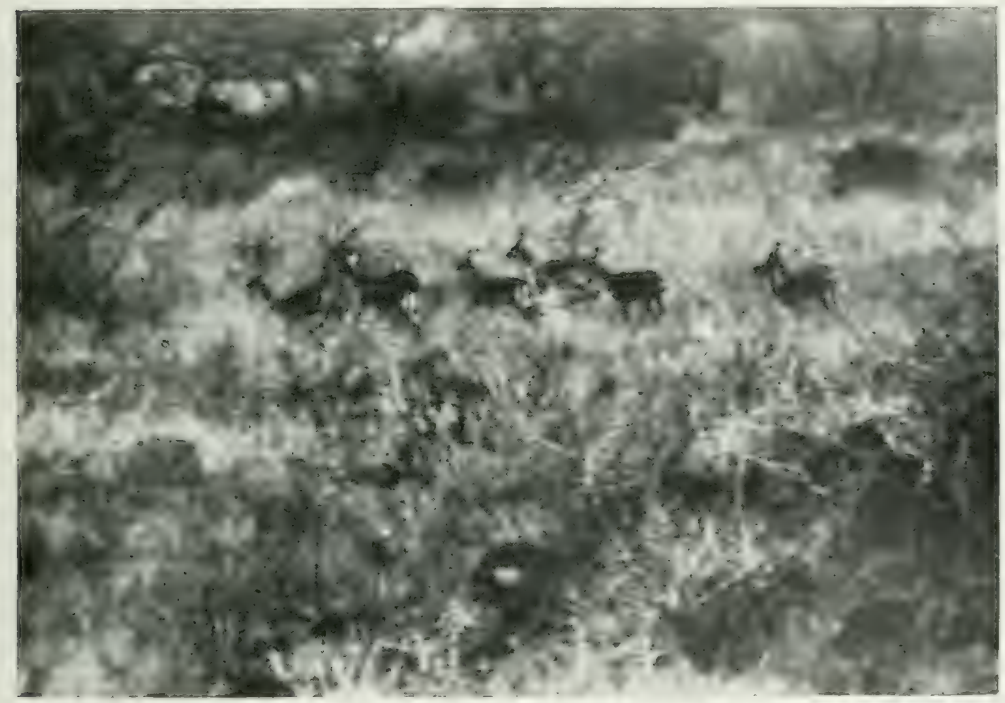

A SMALL HERD OF FEMALE BLACK-TAILED ANTELOPES RUNNING AWAY THROUGH HIGH GRASS.

satisfaction at the sight of his cornfields. And yet these cornficlds are hardly any thing else but an artificially formed bit of bare velt, on which at certain times a short-lived vegetation grows up, whilst at other times the naked soil presents itself to the eye-uninviting, stripped of all adornment, arid and empty. Thus, too, the man who loves wine feels that well-cultivated vineyards are a beautiful sight; but it may be doubted whether he would 


\section{In Wildest Africa}

do so if, say, only cotton-pods grew on the vines! In ancient times, as Humboldt shows, with the Greeks and Romans, as a rule, only country that was "comfortable to live in " was called beautiful, not what was wild and romantic. Yet Propertius ${ }^{1}$ and many others praise the beauty of nature left to itself, in contrast with that which is embellished by art. Then we have a long way to travel through the Middle Ages, when the Alps are described to us as "dismal " and "horrible," till we come to the nature-studies of Rousseau, Kant, and Goethe. At first there were very few to sympathise with them. Their view gradually prevailed, in spite of many backward eddies. Thus Hegel had only one impression of the Swiss Alps, that of a performance tiresome on account of its length-a judgment not far removed from that of the Savoyard peasant who declared that people who took any interest in snow-covered mountains must be insane.

On the other hand, we find in Eastern Asia, and especially among the Japanese, from the earliest times. the most ardent love for nature, and there even the poorest knows how to adorn his home with flowers, and to turn the beauty of the landscape to similar account.

A great part of the interest felt in natural beauty is perhaps to be traced to extraneous considerations. On the other hand, here in Germany we see most of our people full of feeling for our glorious forests and for our German scenery in general. We have to face the prospect, however, of a silenced countryside a countryside:

${ }^{1} \mathrm{Cr}$. Friedlander, Darstellungen ans der Sittengeschichte Roms. 


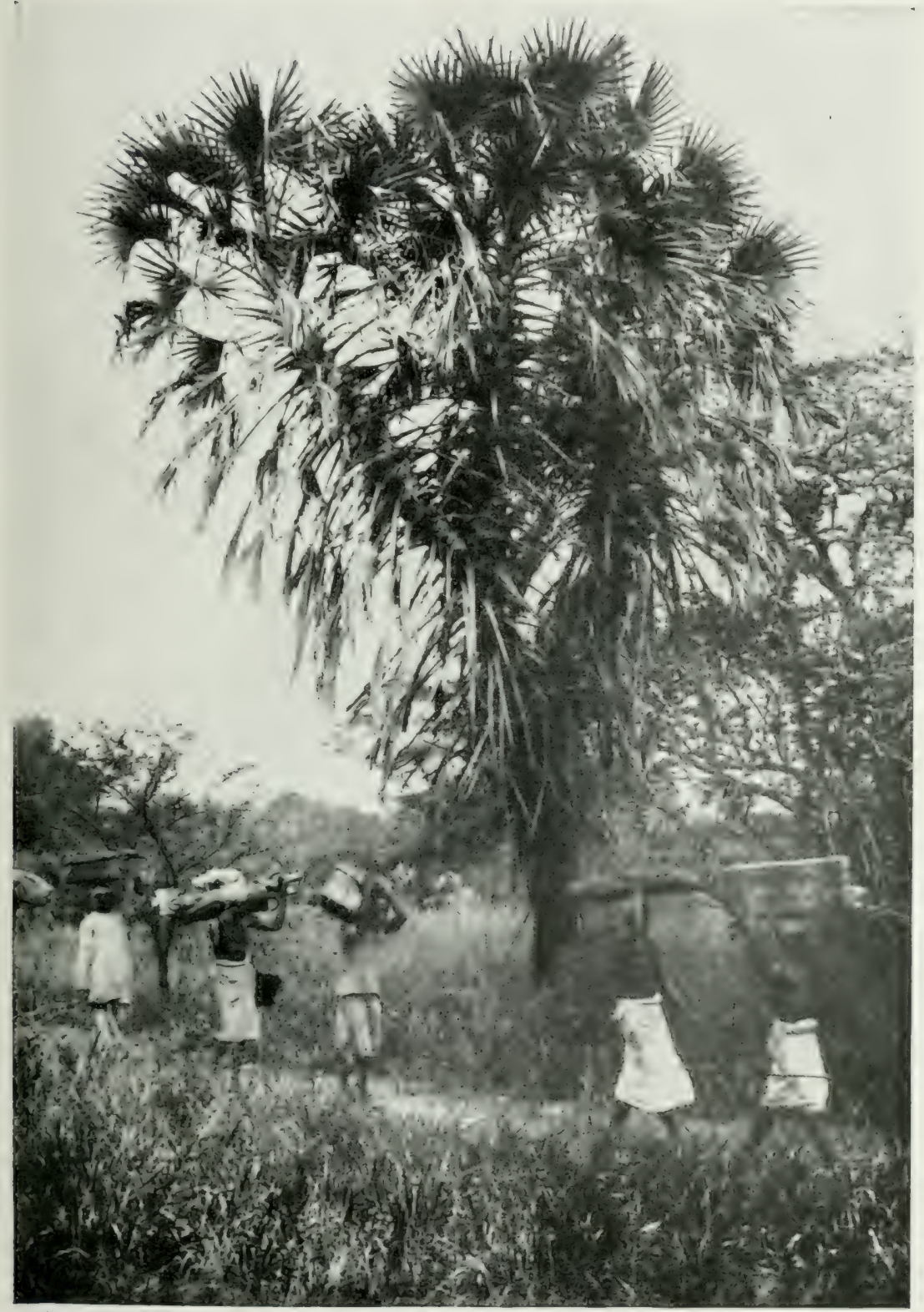

C. G. Schillings, phot. 

without song or music. That is a matter for anxiety. Insects, birds, quadrupeds, life and movement should be a part of the landscape. This iclea should continue to attract more and more adherents. German thought and feeling are altogether in unison on this subject, and it is to be hoped that the cry for the protection of the beauties of nature, for the preservation of the plant and animal worlds, and all that is picturesque in our native landscape, may continue to find expression. The League for the Preservation of the Homeland in Germany gains daily new supporters.

Men like Professor Conwentz and many others have been working for years in this direction, and carrying on a most successful propaganda. This action for the preservation of the Homeland, taken in the highest and broadest sense of the word, must tend to evoke and foster the love of nature and its beauties in ever wider circles.

In other countries, too, steady progress is being made towards the same goal, and the importance of these considerations has long been reconnised. In England and in America a way has recently been found to give practical effect to the idea of the protection of the beauties of nature by measures well calculated for this end. In this connection, too, a refined resthetic culture is gaining ground. I do not at all close my eyes to the difficulty of regulating the conditions bearing on this matter. But in this connection we must not shrink from decisive

${ }^{1}$ In the market of Nice alone, according to official statistics, from November I, I88 I, to the beginning of February I882, I,3 I 8,356 little song-birds were put up for sale. 


\section{In Vildest Africa}

measures. Those who come after us will be the first to prize and esteem these measures at their full value.

What I have here described as something to be desired and worth striving for at home must also hold good for the whole world-the preservation of all that is characteristic, all that belongs to primitive nature, wherever it is to be found.

The beauties of nature are most abundant, and in our time they are all -all-threatened with destruction and in need of protection. Where we can save and preserve any of them, our hands should not remain idle.

But where this is not possible, let us secure "naturedocuments," paintings, representations of all kinds as true to life as may be.

In this way we shall, at least, save for future ages memorials of enduring worth, for which our children's children will give us thanks. 
A RHINOCEROS MOVING SLOWLY THROUGH THE GRASS OF THE VELT-TAKEN WITH THE TELEPHOTO-LENS AT A DISTANCE OF 120 METRES, AND WHERE THERE WAS NO COVER. THE ANIMAL LOOKED REMARKABLY LIKE AN ANT-HILL. ON ITS BACK ONE SEES A BIRD-(BUPHAGUS ERYTHRORHITCLS, Stanl.)-HUNTING FOR TICKS.

\section{I}

\section{New Light on the Tragedy of Civilisation}

THEODORE ROOSEVELT, President of the lished work, Ont-door Pastimes of an American Hunter: "The most striking and melancholy feature in connection with American big game is the rapidity with which it has vanished."

He makes a critical investigation of this disturbing fact, and he most strongly advocates restrictive laws and the establishment of reservations for wild animals. He puts himself at the head of every effort directed towards the protection, as far as may be, of the animal world and of wild nature, and shows by word and deed how even in a brief period remarkable results can be obtained in this 


\section{In Wildest Africa}

direction. At the same time, on every page of his striking work, the President shows that he is in favour of the practice of the chase within proper limits, and thus he by no means takes the side of extreme partisans in this matter. His efforts are of the greatest service to the cause, and will no doubt have extremely valuable results in the United States, where, owing to its peculiar circumstances, the natural treasures of the country were, till very lately, recklessly wasted.

The establishment of the Yellowstone National Park was largely the President's work. In this vast territory no shot may be fired. It forms an inviolable national sanctuary, within whose boundaries life of all kinds is safe. Several similar reservations are already established, or their establishment is projected. Strict protective laws have been some of them brought into operation throughout the States, and some of them gradually extended to various districts according to their circumstances. Whole tracts (as, for instance, Alaska) have been closed for years by law against the hunter. In short, a period of thoughtless ravage has been followed by an era of self-control with a swiftness that no one would ever have expected under the conditions prevailing in America.

The facts I have noted give one something to think about. When in such vast regions of the world measures of this kind are found to be necessary, there must have been strong grounds for them. And, in fact, primitive nature and all its glories were in as serious peril in the United States as in many other parts of the world. The cutting down of enormous stretches of forest, and IOS 
the destruction of the stately representatives of the animal world, went on at giant speed in the United States. The almost complete extinction of the splendicl American hison, that once roamed in millions over the prairies of the United States, is one of the most startling facts illustrating the destruction of wild animals through the introduction of civilisation. This fact had no slight influence in procuring the enactment of severe measures.

In a land like the United States such measures are possible, advantageous, and practicable. In other countries, too, which are in a settled condition, similar regulations have everywhere come into force of late years. Thus, for instance; the remnants of the fauna of Australia are now protected by stringent laws. But quite different, and much more difficult, are the conditions of the problem with regard to Africa. There, more than anywhere else, the time has come for protective regulations. But how can these measures be enforced, however well they may be thought out? We must keep before our eyes the terrible example of the disappearance of the animal world of South Africa, as the result of the extremely rapid spread of civilised life. We can now, with the help of statements made by trustworthy writers, survey the various phases of this utter destruction of animal life during the last century, and so form an idea of what awaits other parts of the Dark Continent.

Powerful voices have been raised of late in favour of the preservation of African wild life, and this especially in England. In this respect, Mr. Edward North Buxton is most prominent in pressing for thorough measures 


\section{In Wildest Africa}

of protection for the African fauna throughout the wicle possessions or spheres of interest of the British Empire. In England, too, many strong pleas have been made in support of the view that even relatively speaking noxious animals should not be deprived by man of the right to a certain amount of protection. Thus Sir H. H. Johnston, the former Governor of the Uganda Province in Central Africa, says in his preface to the English edition of my book Irith Flashlight and Rifle, that in his opinion the weasel, the owl, and the primitive British badger of the existing fauna ought not to be entirely sacrificed to the pheasant-a beautiful enough bird, but, after all, one that must always remain an "interloper"; that the egret, the bird of paradise, the chinchilla, the sea-otter, ${ }^{1}$ and such-like creatures are "resthetically as important," and have the same right to existence, as a woman beautifully dressed in the spoils of these animals. Good pioneer work in this direction must result from the noble-hearted resolve of the Queen of England to put herself at the head of the "Anti-Osprey Movement," organised to save the royal heron from threatened extinction.

There can be no doubt that the complete extermination of any species of animal must excite in the mind of a reflecting man a sense of injustice and wrong; and that this complete destruction of certain species can only be to the interest of all men in general when such animals, of whatever kind they may be, are entirely noxious and

1 Strict regulations have lately been put into force for the preservation of the last-named species. But, as the result of the merciless persecution to which it has been subjected, the sea-otter is all but extinct. 
quite useless. No epoch in the world's history can be set in comparison with ours in so far as it has been the witness, in the course of a few decades, of almost daily progress and improvement in connection with industry, culture, and the whole field of human knowledge. And, moreover, no epoch has been so penetrated with the great thoughts of progressive humanity. The continual employment-in ways that are ever more adroit, ever more complex-of all the resources offered by nature to man, seems at the same time to blind him to certain grave misdeeds that he is actually perpetrating every day. These great crimes against the harmony and order with which nature surrounds us - crimes that it is not easy to make any amends for-are the disfigurement and poisoning of watercourses, the pollution of the air, the laying waste of a portion of the plant world (namely, the forests), and the extinction of some of the animals that live with us.

We do not shrink from the most reckless exploitation of those forests that have come down to us from the primeval past-the vast stores of coal buried deep in the bosom of the earth. The expert can now calculate with certainty that in a few hundred, at the very farthest in a thousand, years these stores will be exhausted. When it comes to this, the triumphant progress of industrial science will no doubt give us some substitute, perhaps even something better; but no technical knowledge, no science, can ever give us back anew those highly developed organisms of the plant and animal world which man to-day is recklessly sweeping out of the list of living things. They cannot restore to us the green woods and their animal life. 
We preserve with punctilious precision every vestige of the art of the past. The older the documents of earlier historic times are, the more eagerly they are coveted, the more highly they are valued. Our collectors gladly pay the largest sums for an old papyrus, an old picture, an object of decorative art, or a marble statue. And, as has been rightly remarked, what warrant have we that some new Phidias, some new Michael Angelo, some new Praxiteles will not arise, and give us something of as high value as these, or even much more perfect? Unreservedly to deny this would be the same thing as to give the lie to the progress of the human race.

But the same man who, in this respect, acts so reverently, so conservatively, looks on with folded arms while treasures are destroyed that ought to be guarded with special affection and care, in these times when the great value of all natural science is so fully recognised. ${ }^{1}$

1 While this book is passing through the press several correspondents have sent me an article published by l'reiherr von Schrötter-Wohnsdorf in the Monatsheften des Allgemeinen Deutschen Jagdschutszereins of August 2.th, 1906. According to this article, during the year 1906 , by ministerial orders, in four of the chief forest districts of East Prussia, sixty-seten head of avild elk were killed off, though hitherto the few remaining living specimens of the elk have been so carefully preserved both on public and private estates. This thorough-going course was adopted for the sake of the preservation of the woods from damage by the animals. That this should have been done in the case of a disappearing species of wild animal, hitherto so carefully preserved, and of which private individuals were allowed to shoot only male specimens, is in open contradiction with those views as to the necessity of protecting the rarer beauties of nature, which are making such progress every day. It seems therefore fitting that I should note the fact here as showing how well grounded is my opinion that the progress of civilised culture is destructive to those treasures of nature that have come down to us from primeval times. 
- New Light on the Tragedy of Civilisation

We organise, at an extremely high cost, expeditions to survey and explore far-off regions. We sink into the greatest depths of the sea our cunningly devised trawlnets, and study with ceaseless diligence the smallest organisms that they bring up into the light of day. We consider the course of the stars, and calculate with precision their remote orbits. We daily discover new secrets, and have almost ceased to feel surprised at each day bringing us something new, something yet unheard of. Much that is thus done to secure the treasures of the past might equally well be done in coming years. But much that we neglect to do can never again be made good, for we are permitting the slaughter, up to the point of extinction, of the most remarkable, the most interesting; and the least known forms among the most highly organised of the creatures that dwell with us on our earth!

An example that appeals to us with terrible force is that of South Africa (taking the country in its widest limits), a region now so largely peopled by Europeans. There has been an almost complete disappearance of the larger animals that once lived in their millions on its wide plains. If one studies the trustworthy narratives of the earlier explorers, one reads that, hardly a century ago, it was not a rare sight to see in one day a hundred, or even a hundred and fifty rhinoceroses, hundreds of elephants that showed little fear of man, and countless antelopes; and one asks oneself, How can it be possible that all this abundance of life has vanished in so short a time? A specimen of the "white" rhinoceros; which in those times was still living in large numbers, is in our day worth a VOL. I 


\section{In TVildest Africa}

small fortune; it is to be found in no museum in Germany', and is simply almost impossible to obtain. This former abundance is now known only to few, and these only specialists engaged in studies of this kind. But to them it is also plain and terribly certain that, where the like conditions come into being; the same process that was at work in South Africa will produce the same results.

There can be no doubt about it. In a hundred years from now wide regions of what once was Darkest Africa will have been more or less cirilised, and all that delightful animal world, which to-day still lives its life there, will have succumbed to the might of civilised man. That will be the time when the fortunate possessors of horns and hides of extinct African antelopes, and the owners of elephant tusks, skulls, and specimens of all kinds will be selling all this for its weight in gold. And no one will be able to understand how it was that in our day so little thought was given to preserving as far as possible all this valuable material in abundant quantities at least for the salic of scicuce, instead of sacrificing it wholesale to the interests of trade, and to the recklessness of the new settlers in those lands. For these men, who have to struggle hard with the new conditions of life and its necessities, can scarcely act otherwise than heedlessly and short-sightedly. They will always take possession of a district before settled conditions are introduced, and before the Government is in a position to enforce the observance of its regulations, however well-intentioned these may be. So it will come to pass that it will suddenly be found no 


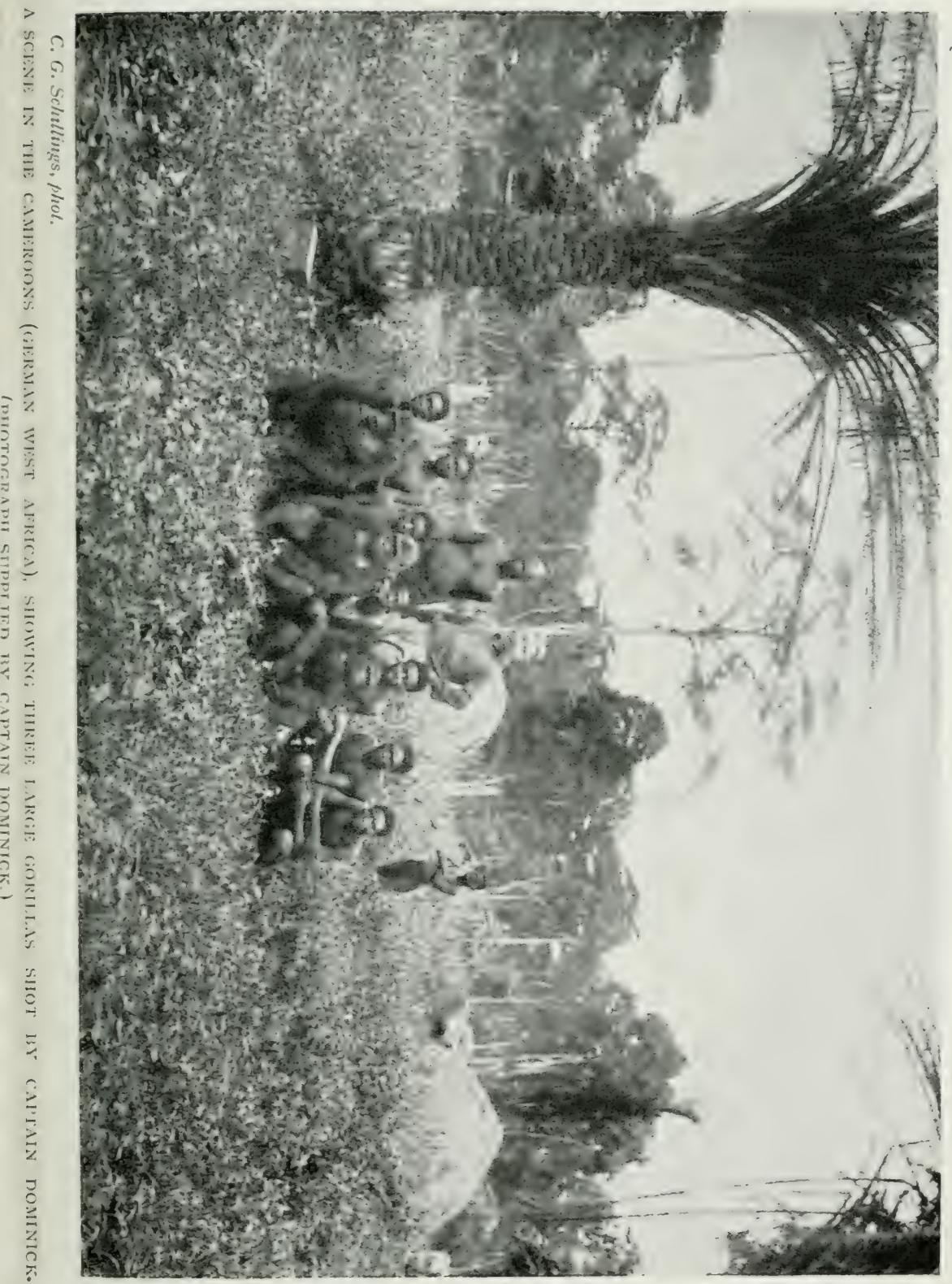



- New Light on the Tragedy of Civilisation

longer possible to provide European collections with even a pair of specimens of the mighty elephant, or to procure other large animals for exhibition in these establishments. And this will be the case not only with regard to the larger species, but the same thing will happen to all others.

The Queen of England has lately expressed the wish that no lady shall come into her presence wearing osprey plumes in her hat. This act of hers should be most heartily welcomed, for the bird world is being destroyed in a way of which only a few experts have any idea. If our ladies only knew that whole species of birds have become extinct, thanks to the fashion of wearing hats trimmed with birds' feathers, doubtless they would no longer pay allegiance to this destructive fashion. The massacre of birds is carried on in some such way as this. The leading firms agree to make this or that bird fashionable. It is thus that the death-sentence of many rare species of birds is pronounced. The traders scattered all over the world give the hunters who engage in this kind of business directions, for instance, to bring in osprey feathers. And how are they obtained? The royal heron, a timid and beautiful bird, is not easy to stalk. But the businesslike hunter knows what to do. He simply kills the herons in thousands and thousands at their nestingplaces. Love for its offspring brings the beautiful creature within range of the gun-barrel of the lurking hunter, who kills thousands of the birds in cold blood when they are gathered together in the breeding season. Countless thousands must be killed, countless thousands more of young helpless nestlings, bereft of the parent birds, must 


\section{In Wildest Africa}

starve to death before enough of these little plumes has been collected to make a load heavy enough to be put on the bearers' shoulders. And now the dealers of the whole civilised world lay in a stock, so that full provision may be made for a form of fashion-mania that may probably last only a few months. Even in the farthest swamps of America, in the lands beyond the Caspian, and wherever the royal heron breeds, one can follow the bird hunter, and see him at his horrible and murderous work. The end is everlasting silence, A rare species is soon utterly destroyed. In the last century alone about two dozen species of birds became extinct. And in these days nearly a dozen more species of birds are threatened with extinction! According to the Reports of the Smithsonian Institute this is notably the case in America with regard to quite as many species. The wonderful birds of paraclise are going ; the latest "trimming" for the hats of American ladies, these dwellers in remote islands of the Southern Seas are to be threatened in a more serious degree, and probably to a great extent exterminated. Everywhere we have the same lamentable facts! It is certainly high time to interfere effectively. I myself think that the best results would follow from an appeal to all noble-minded women.

In Africa I have already observed an example of the disappearance of one species of bird ${ }^{1}$ - every European takes a lot of trouble to get possession of some of the

1 The author believes that he cannot better give expression to his vicws as to the preservation of the beauties of nature, than by reproducing an article on the appearance of the stork in the Soldin district, by Herr 


\section{- New Light on the Tragedy of Civilisation}

much-prized marabou feathers. Now, as long ago as the year I900, at London, as a member of the International

M. Kurth. He writes in Die Jagd, Ilhustrierte IVochenschrift für dentsche Jïger, May I3, I906:

"As for the stork-shooting appointed by the District Committee of the districts of Soldin, Landsberg and Ost-Sternberg for the period from March I to June $\mathbf{I} 5$, it is to be remarked that the opinions held by sportsmen as to the damage done by storks, especially in reference to small game, are very much divided, and that not much can be put to the reckoning of 'Brother Longlegs' of those misdeeds that figure heavily in the accounts of other robbers, such as the crane, the magpie, and all kinds of native birds of prey, and the hedgehog, marten, and polecat. These one and all carry off nestlings, and most of them attack young leverets also. Now if we are to go for the stork, it should of course be done when he is to be found together in too great numbers; and this is entirely the iden of the District Committee. The neighbourhood of Balz bei Vietz on the Eastern Railway has always been remarkable for the number of its storks' nests. One finds two of them on nearly every one of the old barns, a nest at each end of the roof. It was so even thirty years ago, and so it is to this day. But the proprietors of the barns never agree to the nests of the storks being destroyed, or any opposition made to the settling there of these trustful and friendly birds. And for what reasons precisely has 'Friend Adebar' settled in such numbers in this district? Well, here the far-spreading meadows of the Warthe, with their full scope for extended flight, offer him all the food he wants and to spare, and here the frogs' legs must be particularly good. It may be that now and again a young partridge or a leveret strays into Mother Stork's kitchen, but that is the exception. Now if people keep strictly to the object indicated by the District Committee, namely to bring down the numbers of the storks where there are too many of them, one may let it pass. But how many will out of a mere shooting-mania take aim continually at the harmless birds! though such are never genuine sportsmen. How can this be checked? And it should not be forgotten that in the first week of April our African guests are to be found in hundreds along the Warthe brook, whence they then disperse to various parts of the neighbouring districts. Now it is to be hoped that no one will assume that the stork is to be found here 'in too great numbers,' and that therefore-'one may blaze away at him.' In some years this may possibly be the case, but if he were scared out of the district our landscape would be the poorer by the loss of the 
Conference for the Protection of Wild Animals, I did my best to obtain, at least on paper, some measure of protection for the marabou. This bird had not only quite won my heart by its extraordinary sagacity, but for the same reason it was a general favourite even in the times of classical antiquity. My efforts were in vain. And this will mean nothing more or less than the extermination of a large and handsome bird, which is comparatively easy to hunt down, and the rate of increase of which is exceptionally small.

From all these points of view the support of the "League for the Protection of Bird Life in Germany" is to be warmly recommended. In England these reasons have

bird's welcome cry, as has happened in the case of the heron and the cormorant in our district. This last-named bird comes now only seldom, and then only one at a time, to the Netze, near Driesen. There was a heronry formerly near Waldowstrenk in the Neumark district, but it disappeared ten years ago. We must hope that this will not be the fate of the stork, whose appearance has so many links with the poetry of our childhood, and that we shall not be deprived of his presence. What a pleasing sight it is when 'Brother Longlegs' with dignified walk stalks beside the mower at haymaking time, looking so confiding and fearless! And what a joy it is to old and young when the first stork of the season wheels in circles over the homestead, when for the first time he comes down to his old nest, and announces his arrival with a joyful outcry! Must not every sympathetic and thoughtful lover of nature be filled with sorrow and indignation when, on the pretext of petty thefts, but probably out of mere wanton love of destruction, attempts are made to drive out of our country this friendly bird, which is so pleasing an ornament of the landscape? It would really be a crime against the out-door beauty of our native land, and against nature all around us, if out of narrow-minded selfishness we were to extirpate the stork, as happened in recent times to that most splendidly coloured of our birds, the kingfisher, on mere suspicion of its being a 'great destroyer' of fish. I.ove of nature, joy' in nature, is a valuable element in German feeling, and therefore, dear fellow sportsman, let us maintain our good character!" 


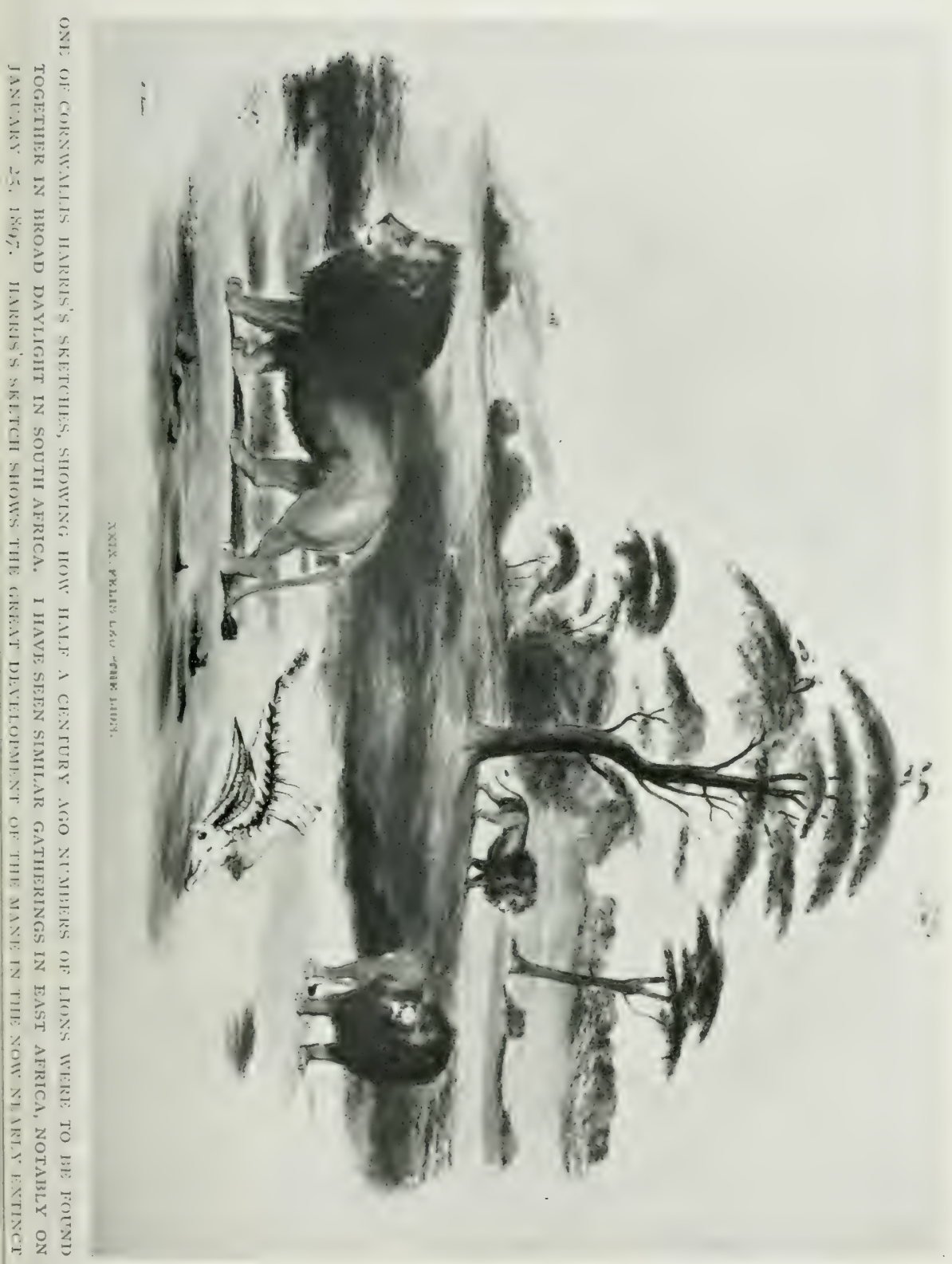



brought about the formation of the "Society for the Preservation of the Wild Fauna of the Empire," which devotes itself to the protection of animal life in general throughout the world-wide British dominions.

Let us now follow a little more closely, under the guidance of English writers, the process of the extermination of the South African animal world. This lamentable work was completed very rapidly in the course of only something like a hundred years. From numerous English authorities, as well as from the publications of the Society already named, I have been able to ascertain that the last "blaauwbok" was killed by the Boers in Cape Colony about the year I800. From extant sketches of this wild animal, it appears that it was a smaller species of the splendid horse-antelopes still to be found in other parts of Africa. During the following seventy-five years the extermination of several other hinds of animals was systematically carried out; and exactly eighty years later the last quagga, a kind of zebra (Equus quagga) was killed by the Boers. In England there is only one single specimen preserved, and that in a very poor condition. It is to be found in the British Museum. A further sacrifice to the advancing Europeans was the giant, wide-mouthed, "white" rhinoceros (Rhinoccros simns. Burch.), a mighty creature, that formerly ranged in thousands over the grassy plains of South Africa. The length of a horn taken from one of them is given as $6 \mathrm{ft} .9 \mathrm{in}$., English measurement! Even as late as the year 1884 , a single trader was able to pile up huge masses, small hills, of these rhinoceros horns by equipping some four hundred tribesmen of the Matabele 


\section{In Wildest Africa}

race with guns and ammunition and sending them out rhinoceros-hunting. Now it is difficult to get even a few specimens of this animal for the museums, and they are almost worth their weight in gold. Information lately obtained seems to indicate that a very small number of these mighty beasts, probably not more than thirty-five in all, are still living their life in the midst of inaccessible swamps in Zululand and Mashonaland, in a district that, on account of its deadly climate, is almost closed to Europeans. However, the Government of Natal has, I am pleased to say, made the killing any animal of this species, without legal permission, a crime to be punished by a fine of $\$$ zoo.

An English officer, Captain (afterwards Sir) William Cornwallis Harris, is an authoritative witness as to the extermination of wild animals in South Africa in $1 \$_{3} 6$, though it must have been going on for a long time before that without any written record. The Boers must have slaughtered hecatombs of wild animals, though up to that date we have no first-hand written evidence on the subject.' Their proceedings were precisely of the same character as the events that have occurred in our own day in

1 We are indebted to the English hunters of those days for all the information we possess as to the wild life of South Africa at that time. If there had not been amongst them men who knew also how to handle the pen, we should have been almost entirely without trustworthy information as to that period. I may take this opportunity of saying a word for the English "record-making sportsman," who is not unfrequently the subject of false and unfounded invectives, which I can only describe as mostly full of fanciful fables. Other lands, other ways, and there are black sheep in every nation. In any case we may take English ideals of sport as our example, and also the regulations drawn up by English authorities for the protection of the animal world. 
- New Light on the Tragedy of Civilisation

connection with the destruction of the elephant, the rhinoceros, and other animals throughout Africa. This destruction goes on silently, and only a few men who have a special knowledge of the circumstances bring some information about it to the world at large. The rest keep silence, and mostly have good grounds for so doing.

The descriptions given by Harris, Oswell, Vardon, C. J. Anderson and their contemporaries give some idea of what enormous multitudes of wild creatures then wandered over the plains of South Africa. We are inclined to underestimate the abundance of the fauna of earlier epochs. The process of animal-destruction by the hand of man has been going on from immemorial times. For thousands of years man has been continually pressing the animal world back more and more, and it has had to give way in the unequal struggle. This process has been going on so slowly and so imperceptibly that it is only by the scanty remnants left from earlier times that we can form some estimate of the wealth that has disappeared. These are no empty fancies. All the lonely far-off islands of the world's seas, the little visited Polar lands, and all the uninhabited steppes and wildernesses give us evidence of this. Not only from the lips of Cornwallis Harris, but also from some of his contemporaries, we have descriptions of the former abundance of wild life in the Cape districts of South Africa. At that time the country was, in the literal sense of the word, covered with countless herds of Cape buffaloes, white-tailed gnus, blessbock, bontebock, zebras, quaggas, hill-zebras, hartebeests, eland-antelopes, horseantelopes, oryx-antelopes, waterbuck, impallah-antelopes, 


\section{In Wildest Africa}

springbocks, and ostriches. Herds of hundreds of clephants were to be seen. Every marsh, every river-bed, was literally orercrowded with hippopotami. All other kinds of animals that are now so scarce, such as the large and handsome kudu, and all the different kinds of small wild animals, were to be met with in vast numbers. Although since the year 1652 South Africa had been to a continually increasing extent uccupied by the Boers, all these wonderful things had managed to survive in rich profusion up to the moment when, about a hundred years ago, the great war of extermination began. Various causes contributed to bring this about: the increasing numbers of the settlers, their continual penetration farther and farther into the interior, and, above all things, the improvement of firearms.

The natives, although very numerous in South Africa, had, as happens everywhere, left the animal life of the country in its abundance to the Europeans, who were overunning the land in increasing numbers. It was reserved for these to bring the war of extermination to an end in a short time. Truly a melancholy spectacle!

Wilhelm Bölsche describes all this in fitting words: ${ }^{2}$ "In Africa," he says, "a wonderful drama is to-day unfolding itself before our eyes. It is the downfall of the whole of a mighty animal world. What is being destroyed is the main remnant of the great mammalian derelopment of the Tertiary period. (Ince it spread in the same fulness over Europe, Asia, and North America. Now in its

${ }^{1}$ In a review of my book With Flashlight and Rifle (German edition). 


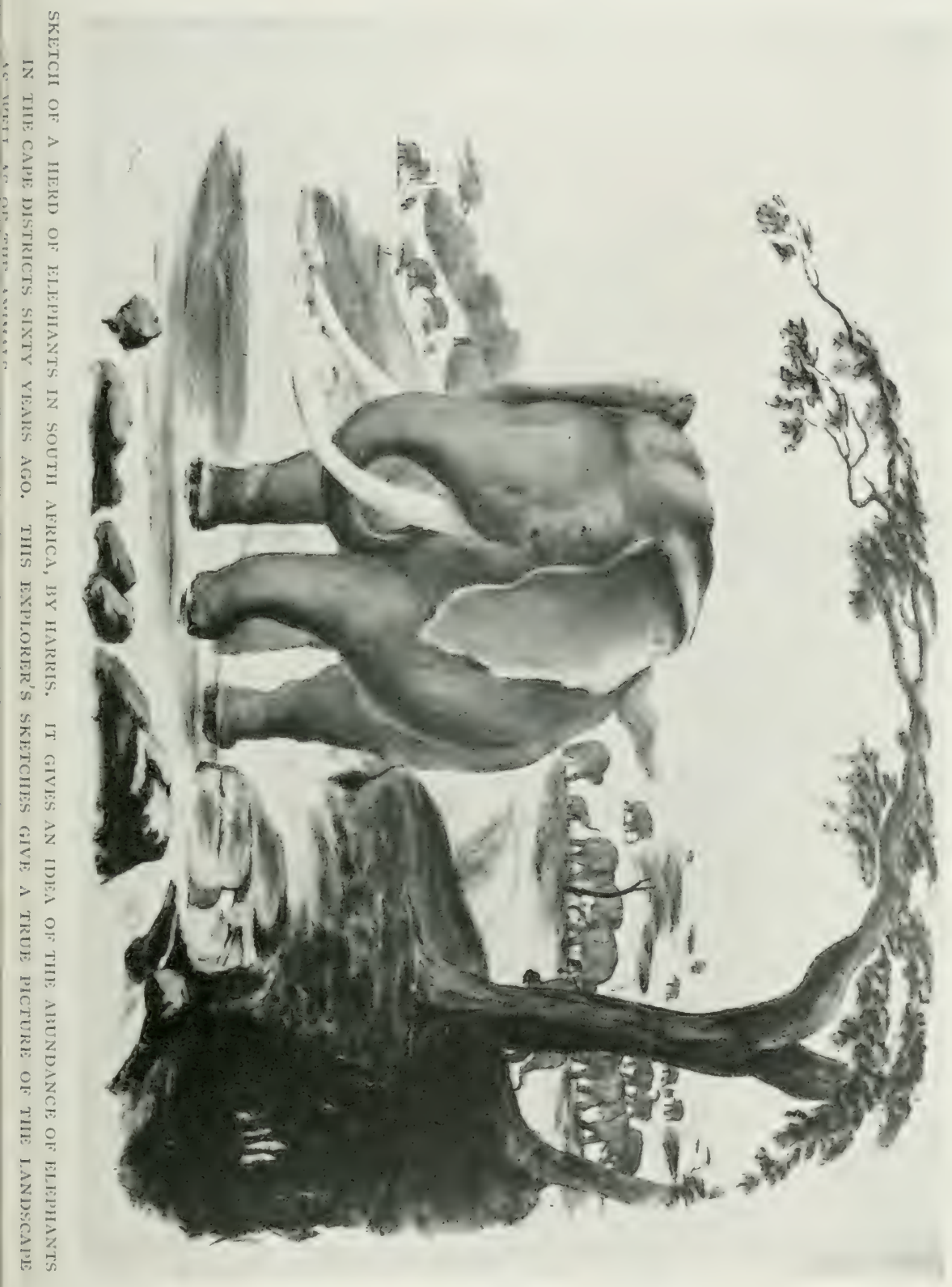



last refuge this most wonderful wave of life is rapidly ebbing away. Everything contributes to this resulthuman progress, human folly, and even disease among the animals themselves."

To give an example: Through the trifling fact that we have ivory balls for billiards, the African elephant goes to destruction. The individual cannot stop this; but what he can do is to secure more material for each special branch of science before the door is closed, and to once more observe in their primeval surroundings the last elephants, wild buffaloes, giraffes - those last living vestiges of the Tertiary period.

But above all, the sketches of Le Vaillant, a French explorer, who, about 1780 , set out from Cape Town on his travels into the interior, are of great importance for our study of the former abundance of animal life in South Africa. They are all the more interesting for German readers because he traversed part of what is now German South-West Africa, and gives in his book an account of its condition at that time. He, too, tells of absolutely incredibly great multitudes of wild animals; on the banks of the Orange River he comes upon great herds of elephants and giraffes, and he cannot find enough to say of the astonishing wealth of animal life. For those who know German South-West Africa, his narrative is of special interest. He formed large collections which he brought back with him to his native country, and to all appearance is a fairly trustworthy authority, though at the same time, like many contemporary and later travellers, here and there he makes assertions that are VOL. I 
clearly unwarrantable. For instance, in one place he tells how he once rode a zebra, that he had wounded, for a considerable distance, back to his camp.

Some fifty years later, at the period of the journeys of Captain William Cornwallis Harris, ${ }^{1}$ as I have already remarked, the same conditions prevailed, with regard to the abundance of wild animals, as in the days of Le Vaillant. It was almost a daily experience for the traveller to be molested by lions. The Vaal River then teemed with hippopotami. What is now the site of Pretoria was inhabited by a number of rhinoceroses, that were absolutely an annoyance to the explorer: "Out of every bush peeped the horrible head of one of these creatures." Of the neighbourhood of Mafeking he tells us that the gatherings of zebras and white-tailed gnus literally covered the whole plain; that with his own eyes he had at one time seen at least fifteen thousand head of wild animals! In another pliace he tells us of an absolutely orerwhelming spectacle. He saw at the same time more than three hundred elephants; to use his own expression, the plain looked like one undulating mass.

William Cotton Oswell, whom I have mentioned in my earlier work, and who died as lately as 1893, knew the countries of South Africa in the days of Livingstone, and gives the same account of them as his predecessor Harris. He once came upon more than four hundred

' Sir William Cornwallis Harris must be considered as a quite trustworthy authority. His works are indeed the most complete first-hand evidence we have as to the state of the fauna of South Africa at the time. 
elephants gathered together in one herd on the open velt. Unfortunately, like so many others, he published very few sketches.

Gordon Cumming, a traveller well known to the German public through Brehms' Ticrleben, has also left us sketches of those days that corroborate the descriptions given by his contemporaries. He tells how, in the year $\mathrm{I} 860$, a great drive was organised in the Orange Free State in honour of the Duke of Edinburgh, afterwards Grand Duke of Saxe-Coburg-Gotha. The number of wild animals driven together by the natives, which included zebras, quaggas, gnus, cow-antelopes, blessbock, springbocks, and ostriches, was estimated at five-and-twenty thousand. The number killed on this one day was reckoned at about six thousand animals, and a number of natives were trampled to death by the herds of wild beasts.

At this time there were still Europeans in South Africa who made elephant-hunting their ordinary business. Now there are neither elephants nor indeed any other kind of wild animal in numbers worth mentioning in these once rich hunting grounds. They have all been killed off in the course of a hundred years. Where once hundreds of thousands of gnus lived their life, there are now only a few hundred specimens carefully preserved and guarded. And the same is the case with all other wild animals. Iany species are gone completely and for ever. A similar proccss will go on slowly but surcly throughout the whole of Africa, wherever civilisation penetrates. There is only one chance of the beautiful wild life of Africa being 


\section{In Wildest Africa}

permanently preserved, and that lies in the hunters themselies consenting to protect and spare it.

It has been rightly remarked by such a competent authority as A. H. Neumann (who is, moreover, one of the most experienced of English elephant hunters) that the continued existence of many wild African species is not incompatible with the progress of civilisation. He points out that we can only reckon with some degree of certainty on the effective preservation of wild animals, where not only reservations have been established for them, but where also a considerable amount of control can be exercised over both Europeans and natives. In his opinion, for instance, a mere regulation forbidding the shooting of female elephants is impracticable: "I should like," he says, "to see one of those who have drawn up such a regulation come into the African bush, and there show us how we are to distinguish between female and bull elephants in these impenetrable thickets."

In the British colonies in Africa reservations for wild animals have been established with most successful results. Those of British East Africa, the Sudan and Somaliland, and finally of British. Central Africa, taken together, have about five times the area of the Victoria Nyanza.

By means of reports made as carefully as possible by the district authorities, estimates have been obtained of the numbers of existing wild animals. In the laying out of the reservations the very migratory habits of the African fauna have been taken into consideration as far as is practicable, and by strict protective regulations of 


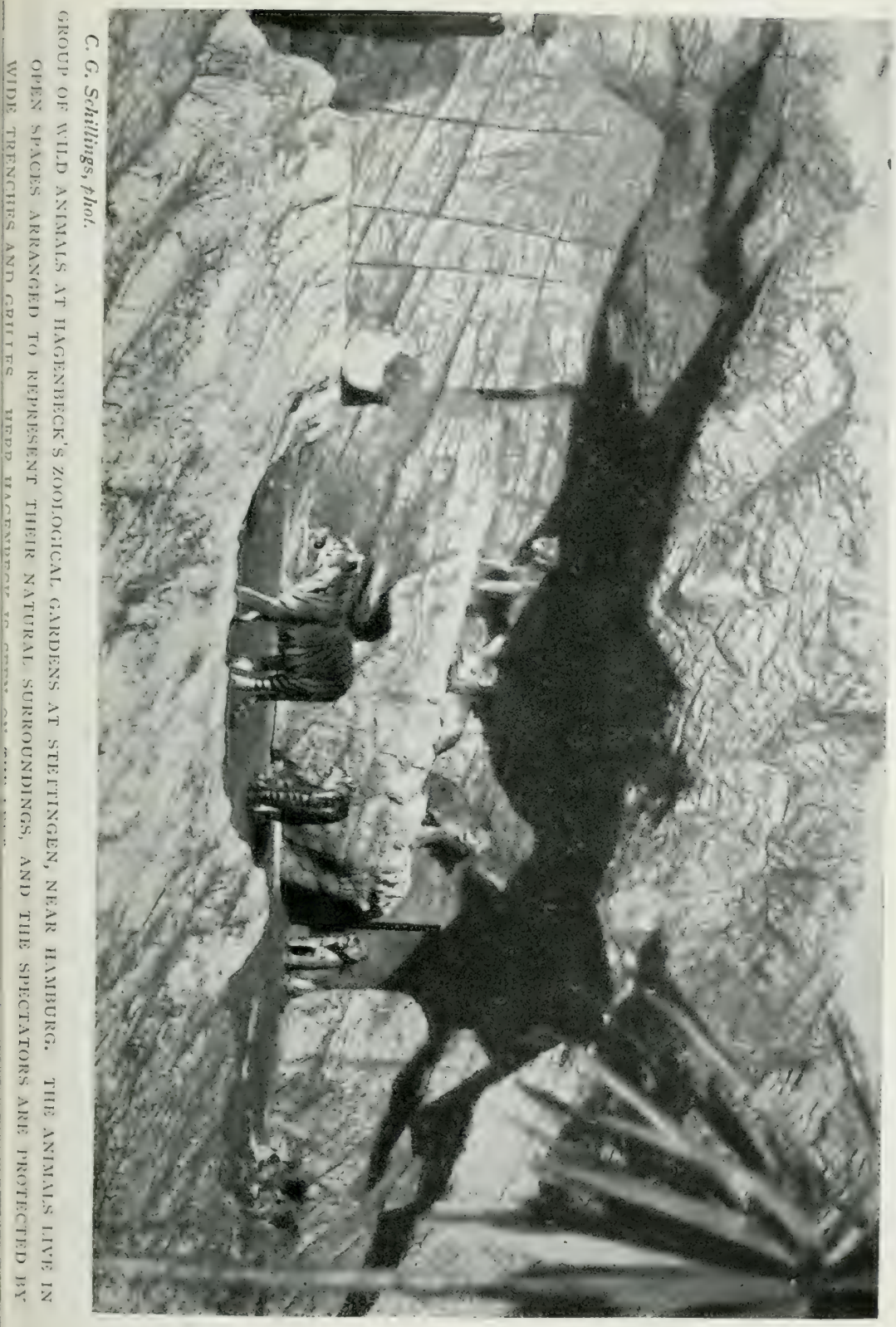



various kinds most satisfactory results have been secured. In the Transvaal Colony, too, a reservation has been marked out in the Barberton district between the Olifant River and the Portuguese frontier. Any one shooting in this reservation without a permit is liable to a fine of $£ \mathrm{roo}$, or six months' imprisonment. There is a very interesting official report as to the wild inhabitants of this reservation. "It contains one old rhinoceros (with shotmarks on its hide), a small herd of elephants, a considerable supply of ostriches, from five to nine giraffes, a satisfactory quantity of gnus, and also of 'black-heeled' or impallahantelopes, two or three small herds of buffaloes, several herds of zebras, numerous waterbuck and kudus, and a small number of horse-antelopes. On the other hand, whether oryx-antelopes and eland are still to be found there appears to the author of the report in the highest degree doubtful."

However, in the extensive reservations that have been established in other British possessions in Africa, and especially in those of the Sudan, a large number of the beautifully formed dwellers of the wilderness still live their life, and this must be a delight to the heart of every sportsman.

It is to be hoped that through thus establishing "sanctuaries" (as the English call them), with the consequent supervision, a means has been found of protecting the indigenous wild life of Africa, as well of America, for a long time to come.

In German colonies, too, efforts are being made to preserve, as far as possible, the native fauna. The more 


\section{In Wildest Africa}

our views can be made clear, the more complete the survey of this difficult subject can be made ly the combined experience of many experts being gradually brought to bear together upon it, the sooner may we anticipate Satisfactory results from this co-operative action. For years I have been following with close interest everything connected with this question, and my wide correspondence with officers, officials, and private individuals warrants me in concluding that on all sides there is an energetic movement in progress. Of course, we have to face serious difficulties in such a campaign. Thus it seems, according to numerous and trustworthy reports, that the attempt to establish Boer settlements in the Kilimanjaro district in East Africa has had, and still is having, very fatal results for the once splendid wild life of that region. And, indeed, it is no easy matter to reconcile a colony of Boers-the people who have already made such a clean sweep of the wild life of South Africa-to the preservation of the fauna of the country. One can see how difficult the regulation of these matters is for the authorities.'

We must not forget also that, as a result of the wonderful improvements in firearms, the problem of the protection of wild animals presents itself to-day in quite a different fashion from that of the days of the hunters of fifty, or even of twenty-five years ago.

But it is not the individual hunter whose interest lies

1 On the part of the Government and the local authorities everything that is possible is being done to settle this difficulty. But unfortunately their efforts seem to have little success. 
in sport or science ${ }^{1}$; it is not the man who brings us the first knowledge of many of the inhabitants of the wilderness, and first arouses our interest in them; it is not such as these who should be regarded as the destroyers of the fauna of a foreign land. Rather this is the work of all those powerful influences that everywhere combine to this end during the introduction of civilised life. It has indeed been already proposed, in all seriousness, by some men of science to completely extirpate the wild animals of East Africa, in order thus to circumvent the tsetse fly and other minor pests that may perhaps communicate disease from the wild to the tame cattle. And this, too, before it can be said with any certainty whether these cases of infection do not arise only from a number of very small animals which it would be impossible to exterminate!

Our most important task is now to obtain an accurate knowledge of the fauna of foreign lands. For this purpose we must collect materials which will render the study of this wild life of other lands possible to our scientific institutions; which will place them in a position to give to a wide public an idea of all these rich treasures, and thus awaken an intelligent love for them in the hearts of the pioneers of civilisation.

And then we must devise practicable measures of protection. This is a wide field of labour. The hunter

${ }^{1}$ Cf. my book With Filashlight and Rifle, p. 736, where a statement by Professor P. Matschie, the Custodian of the Royal Zoological Museum at Berlin, will be found, bearing out the truth of what is here remarked. 


\section{In Wildest Africa}

himself must take in hand the intelligent preservation of the wild animals. The measures of protection must be suited to the varying conditions of the wide hunting grounds of foreign lands, and must not be considered only from the stay-at-home point of view.

This is not to be done by mere laments over the extermination of wild life, or even by merely putting limitations on the enjoyment of the chase by the individual hunter. On the contrary, a beneficial result can be obtained only by all European travellers in those countries interchanging their experiences, collecting material, and exerting themselves to the utmost and in concert to devise measures that will, as far as may be, put a stop to the threatened extermination.

This is a great and noble task. 


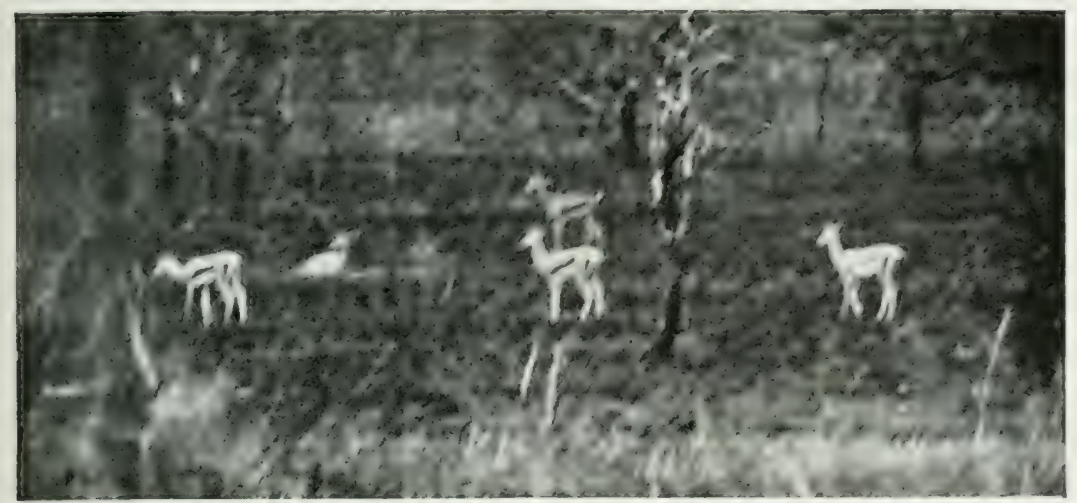

YOUNG GRANT'S GAZELLES ON A BLACK-BURNED STRETCH OF VELT.

\section{IV}

\section{The Survivors}

$\int \begin{gathered}O \text { learn to know anything with precision, to devote } \\ \text { oneself to it and master it in its smallest details, one }\end{gathered}$ must generally make its study a labour of love. So the spread of more exact knowledge of the manifestations of nature around us must go hand in hand with the awakening of love for them and for the splendours they present to our view. And with this increasing impulse towards research and knowledge must come the desire to prevent as far as possible the rapid destruction of fauna and flora. Public opinion, in truth, has begun to range itself on the side of these much menaced glories of nature.

We have to observe and investigate. We have to get together some small portion of the vast material that is often so uselessly squandered, in order to employ it in the service of special branches of science, and to make some closer knowledge of these things accessible to every one. 


\section{In Wildest Africa a}

We have to establish great collections formed on a definite

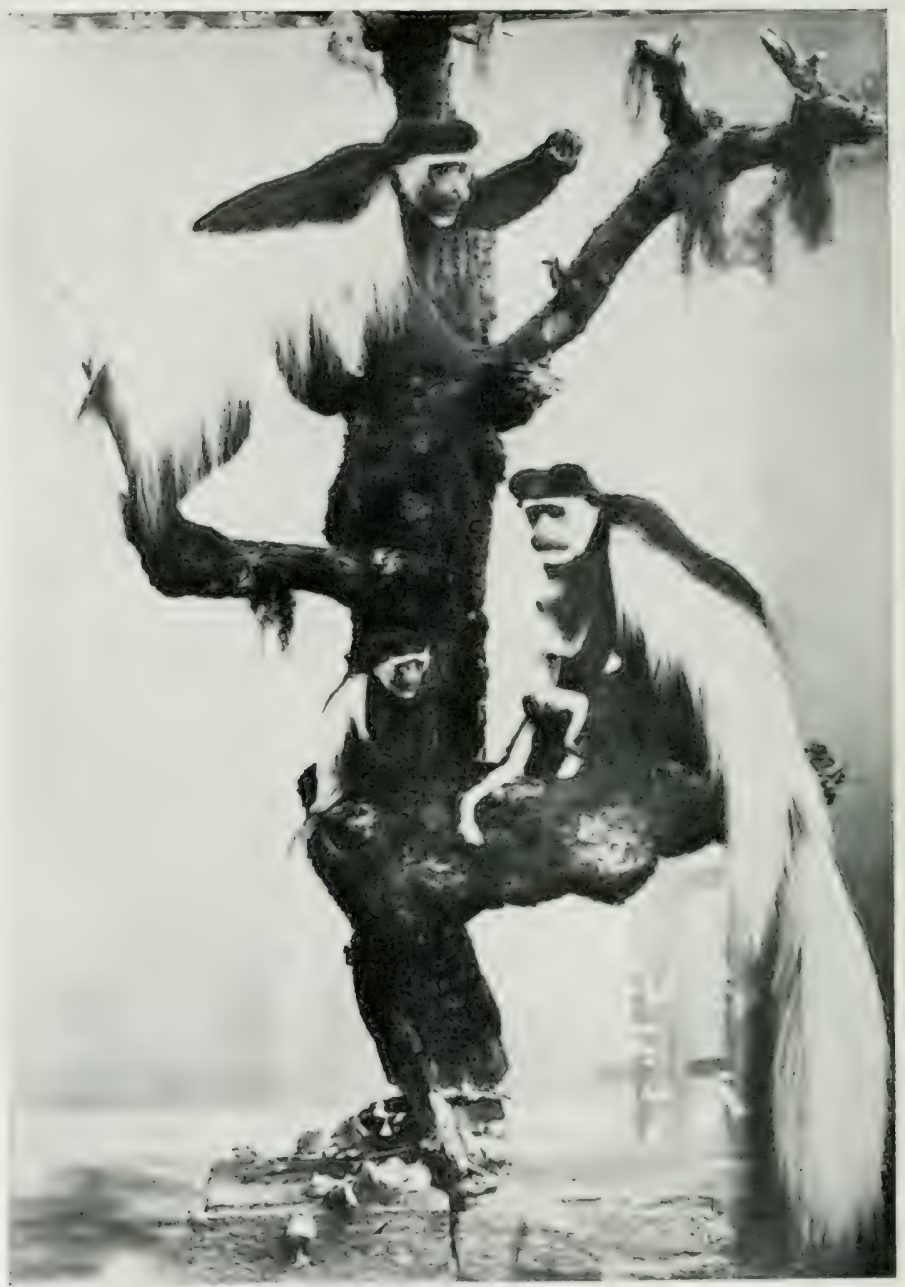

GROUP OF 'MBEGA MONKEYS. WITH THEIR WHTE-COATED YOUNG (FIRST DISCOVERED BY THE AUTHOR).

plan, and everywhere to save as much material as possible for scientific and educational purposes, so long as it can still I 40 
be done. "If these ideas could be brought home to the

Kotigi. Zazlósiesches teuscum.

s.

s marn.

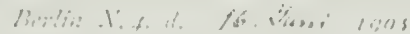

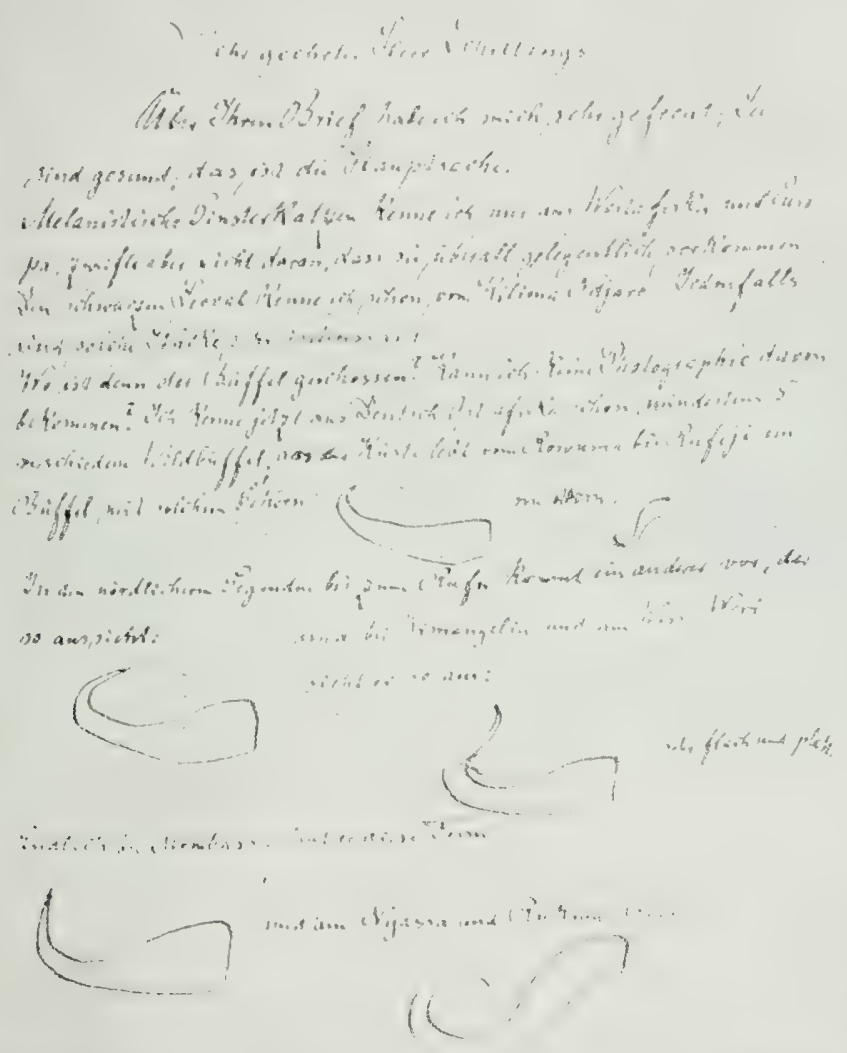

LETTER FROM PROTESSOR P. MATSCHIE, THE LEADING AUTHORITY ON THE DISTRIBUTION OF THE MAMMALIA OF GERMAN EAST AFRICA.

right quarters, millions would be made available for this object," writes one of the most learned specialists in these 


\section{In Wildest Africa}

matters. Our zoological gardens and museums are already doing their best, but they are hampered by the want of pecuniary resources. Whilst the largest sums are freely provided for the purchase of antiquities, there is a dearth of means for doing what is necessary to save the treasures of our vanishing fauna while there is still time!

Other countries, America for instance, set us a glorious example. There you see public collections formed, affording panoramas of animal life so splendid, so beautiful, and planned on such grand lines, that the love of nature must be lighted up in the hearts of all who visit them.

What can be saved of these disappearing treasures must suffice for all time, and must in part at least be preserved in fire and thief-proof "zoological treasuries," for it will be impossible to obtain such things again in the future, no matter what efforts may be made. Thus a great and difficult task presents itself to our museums. We can rightly require of them that they shall not merely exhibit the principal species of the animal world, but that they shall also preserve specimens of the most striking representatives of our still surviving fauna that are likely soon to become extinct. And these specimens must be guarded by all the resources of art and science against light and any other influence that might injure them. For such at far-seeing policy posterity will be grateful to us.

It seems, however, as though some unlucky star presided over the collecting of the larger species of the animal workl. Let any one devote himself to these special pursuits and objects, and even if he win thereby the approval of experts and of wide circles of the public, still a certain odium will 


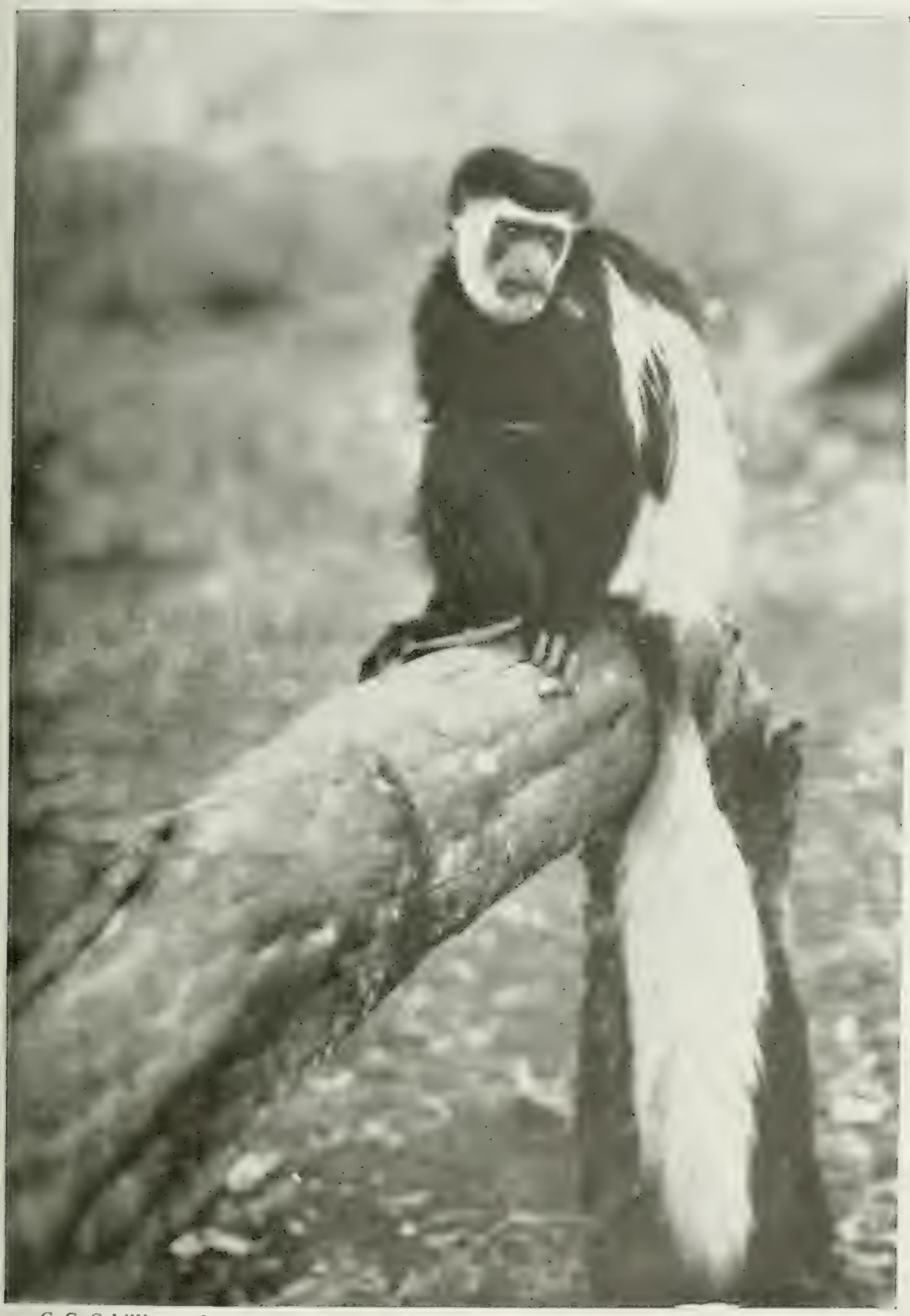

C. G. Schillings, plot.

A 'MBega (colobus caudatus, Thos.)

[p. 143 


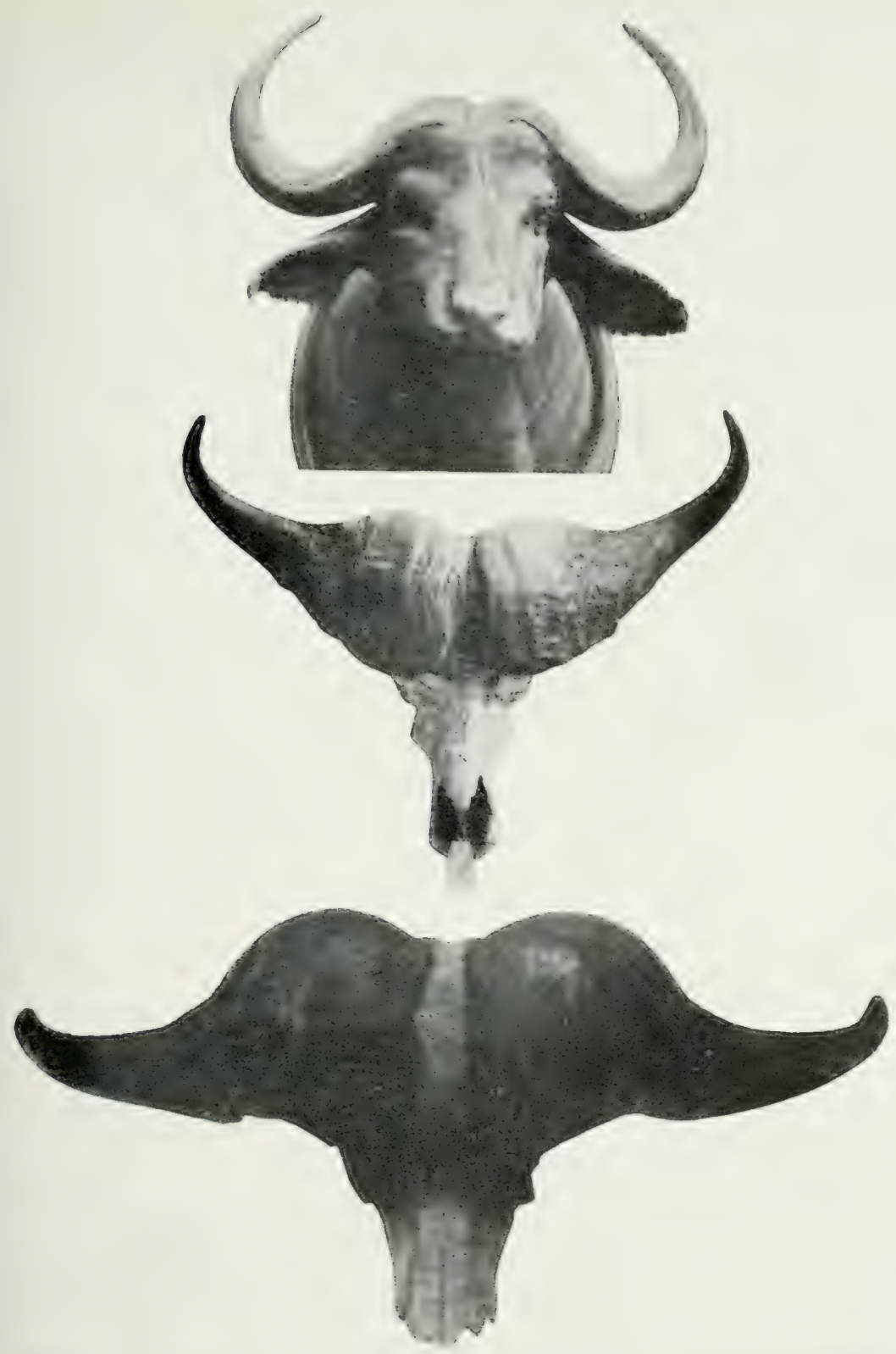

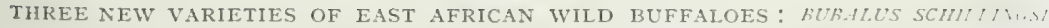
Mtsch. spec. nov., FROM THE MIDDLE PANGANI, LAKE DJIPE, MOMBASSA; ILCT.ILCS WCHAHKW:IS, Mtsch. Spec. nOv., FROM UPOGORO, 'NDEMA, 'MBARAGANDU AND

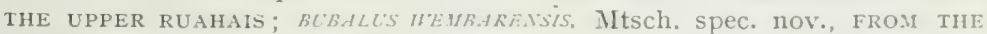
TSHAIA MARSHES IN THE SOUTHERN WEMIBERE STEPPE. THE ILLUSTRATIONS SHOW HOW GREATLY THE FORM OF THE BUFFALO'S HORNS VARIES IN DIFFERENT DISTRICTS, AND GIVE A PROOF OF THE IMPORTANCE OF SCIENTIFIC COLLECTIONS FOR EACH SEPARATE RÉION.

I have to thank Professor Matschie for the two lower illustrations. 

seem to attach to him. Obviously he must kill a certain number of animals, that are often quile unknown till then, and in almost every case have been hardly studied at all. in order that he may add them to the collections belonging to his native country. He gains the gratitude of science and of the learned; but he has to encounter the prejudices of others. People think that they are justified in throwing upon him, the scientific collector, the reproach of being an exterminator.

Those who speak thus completely forget that it was through the material thus placed before their eyes that they themselves obtained their very first knowledge of these beautiful creatures; that till then they hardly took any interest in such things; and that it is only by means of knowledge secured in this way that regulations for the preservation of these beauties of nature can be devised.

Let us suppose that every museum and scientific collection in the world were provided with a series of specimens of all the varieties of the animal world that are now most seriously threatened with extinction; let us further suppose that each of these institutions secured, besides, duplicate series of the hides and skeletons of each species. To make a striking comparison, all this, beside the wholesale destruction of the animal world of which we have to complain, would be like a week-end sportsman perhaps killing one hare during his whole life compared to the millions of hares killed every year in Germany.

If a species is already reduced to such a state that the taking of a few hundred, or even a few thousand, specimens IOL. I 145

IO 
In Wildest Africa $\rightarrow$

for scientific purposes will exterminate it, we may say

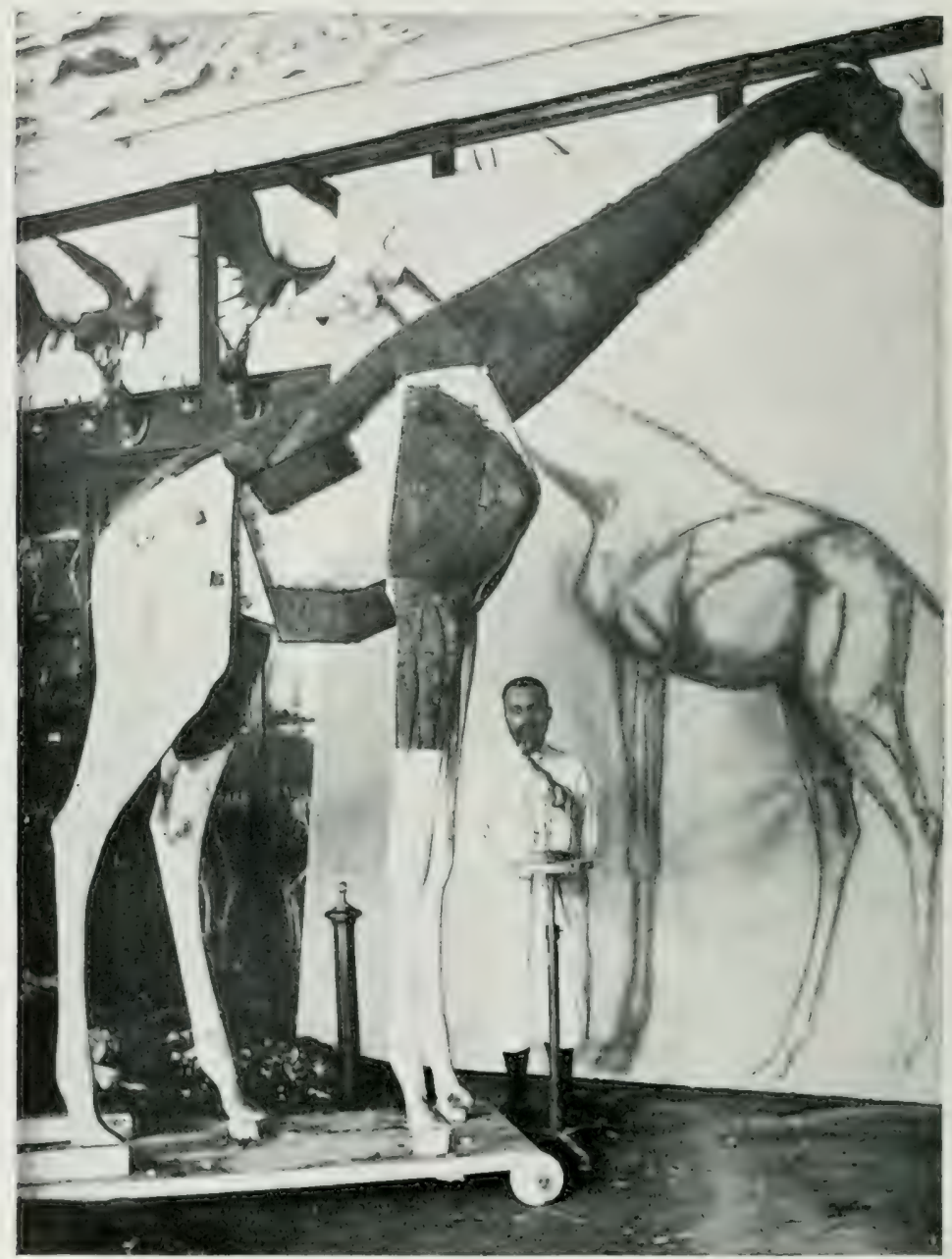

MODERN METHOISS OF TAXIDERMY : SETTING U

generally that, even without this proceeding, it is inceitably doomed to extinction. But the wretched eng-collecting 146 


\section{- The Survivors}

by youths, for instance, is quite a different matter.

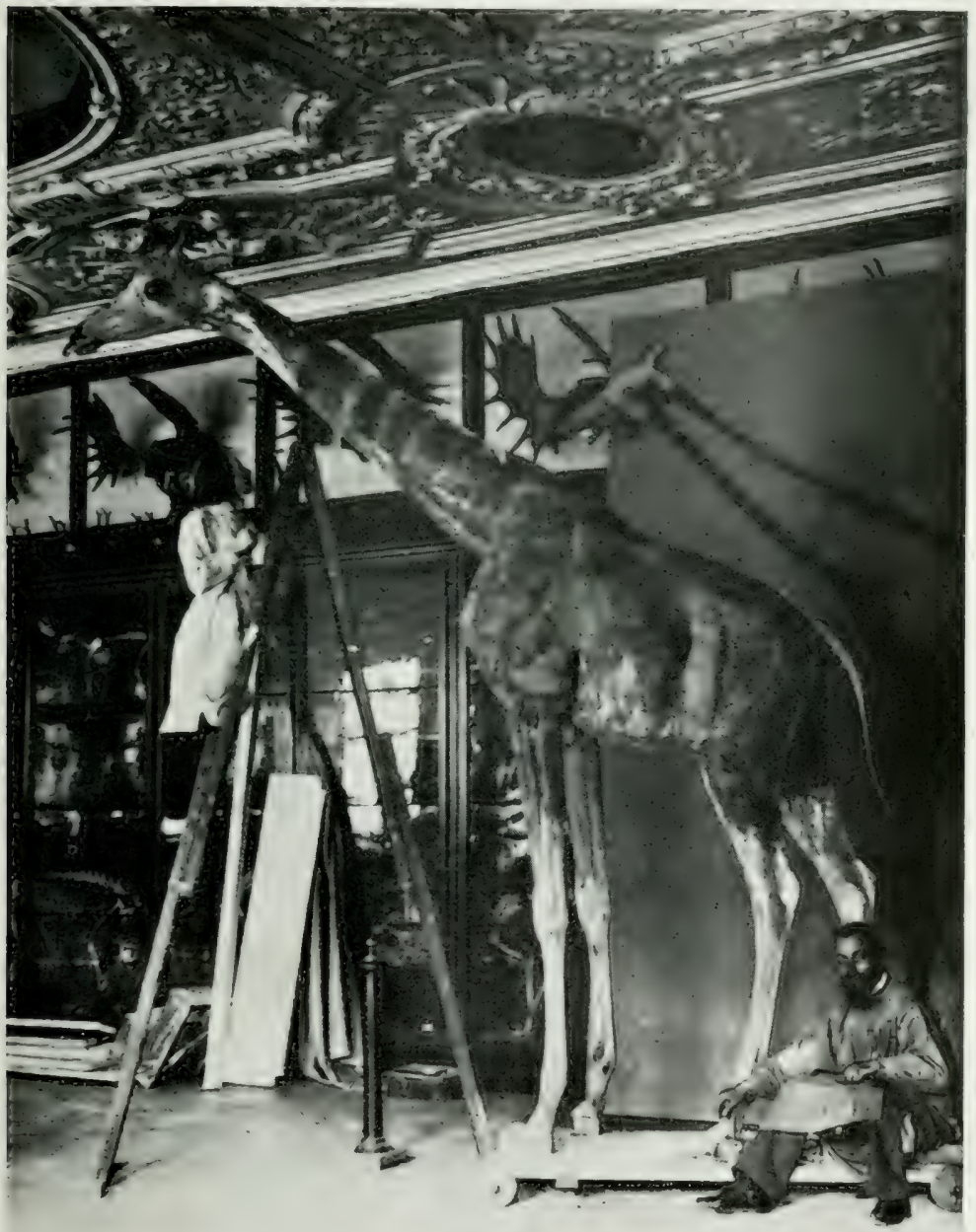

ONE OF MY SPECIMENS IN THE MUNICH MUSEUM.

Certainly there must be a great - deficiency, when continually, year after year, wood and meadow are searched 


\section{In Wildest Africa a}

for birds' nests by thousands of boys. 'This is obvious,

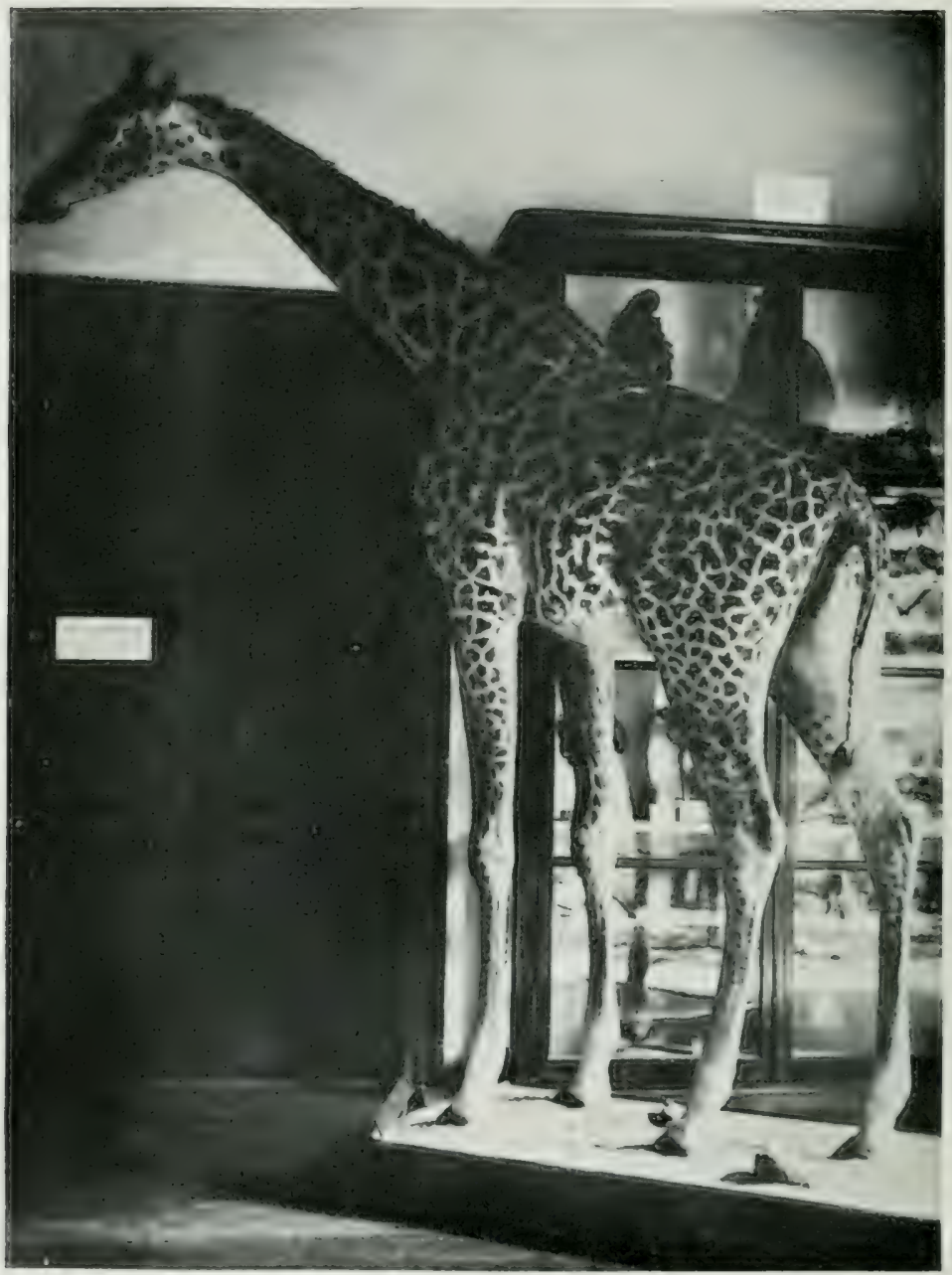

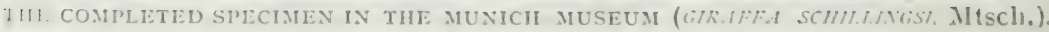

and thus the rarer species are threatened in their very (.xiste.1)1 


\section{a The Survivors}

Great stress ought always to be laid upon the point to

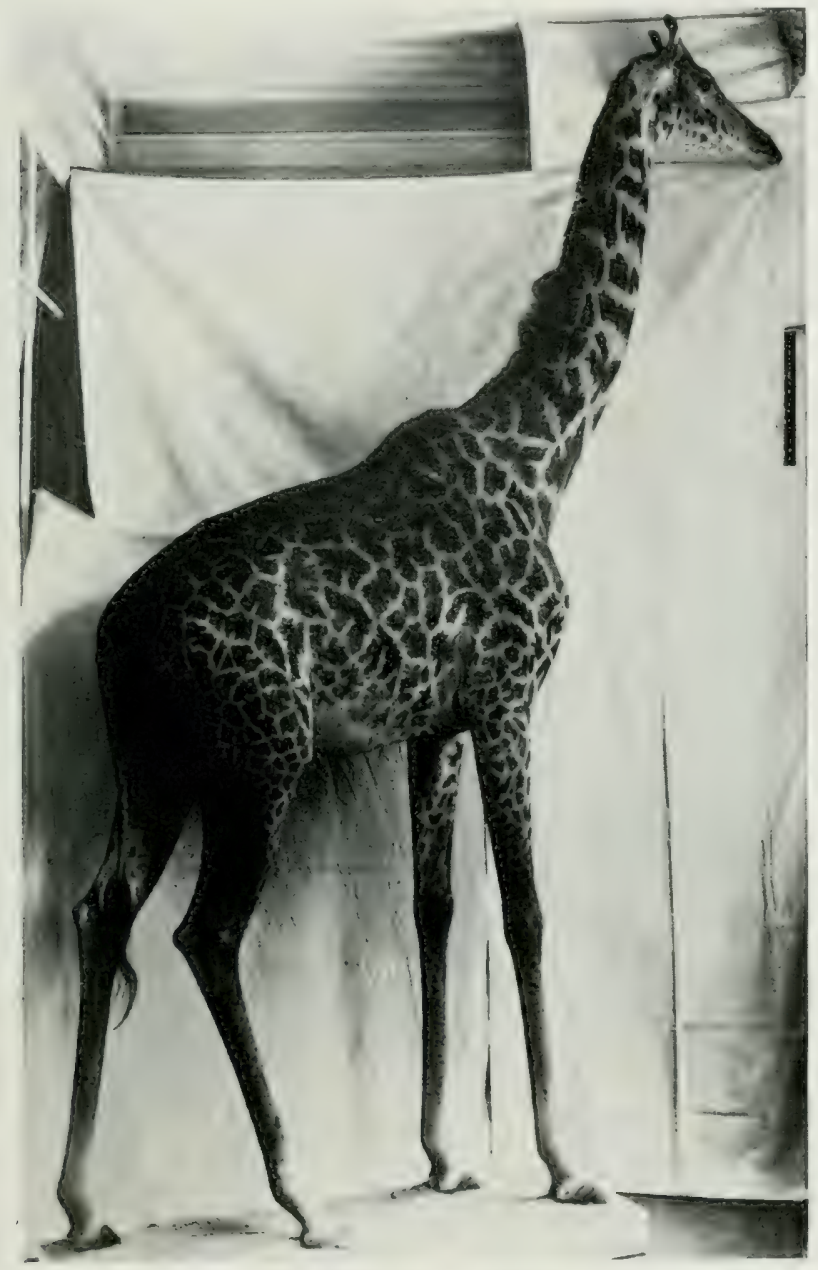

ANOTHER OI: MY SPECIMENS IN THE STUTTGART MUSEUM.

which I have here called attention, and I can appeal to every expert on the subject for confirmation of my opinion. 


\section{In TVildest Africa}

I think that I have earned a special right to speak on this matter. For the last fifteen years I have hardly ever carried a gun when at home in Europe; I have refused the most pressing invitations to shooting parties; and I have sought pleasure only in the sight of our native wild animals, which I know so well, and in secretly watching

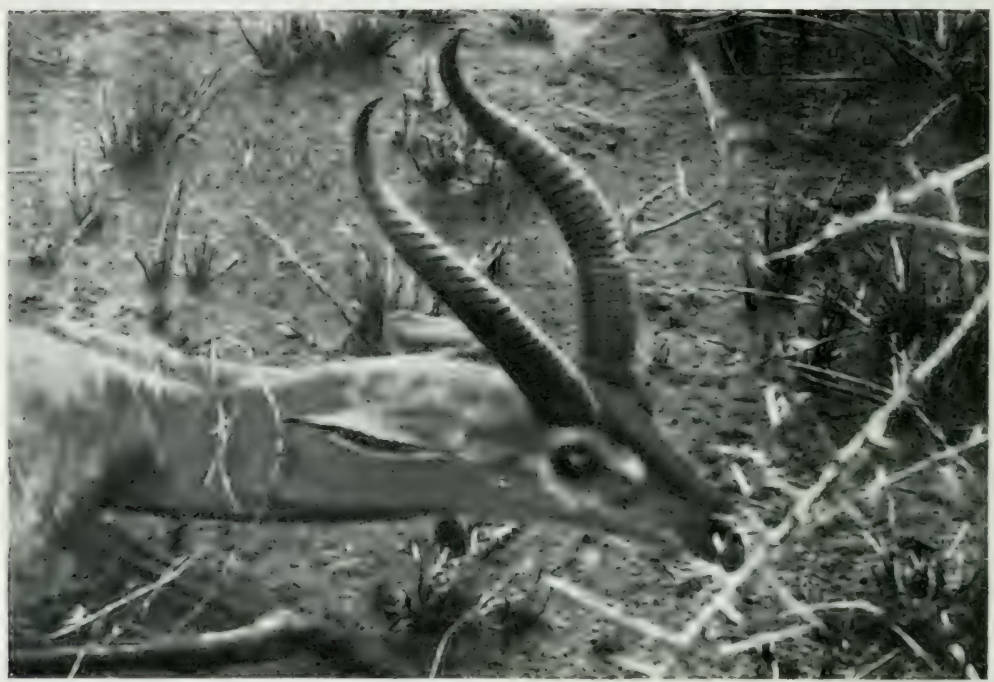

PHOTOGRAPHIC STUDY OF A MALE GIRAFFE GAZELIE (LITHOCR.INTSIIILIERI Brocke) SHOT BY TIIE AUTHOR. AN EXTREMELY BEAUTIFUL AND RARE SPECIES, FIRST SEEN BY THE AUTHOR IN GERMAN EAST AFRICA IN ISQG.

and observing them. But in the midst of a yet unstudied foreign fauna, of which we still know little or nothing. where there is question of first obtaining some scanty knowledge oneself, and forming collections for definite scientific research-in the midst of an animal world of this linul I would not hesitate to shoot even lature numbers of each species. For there would be good reason for not merely 


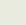




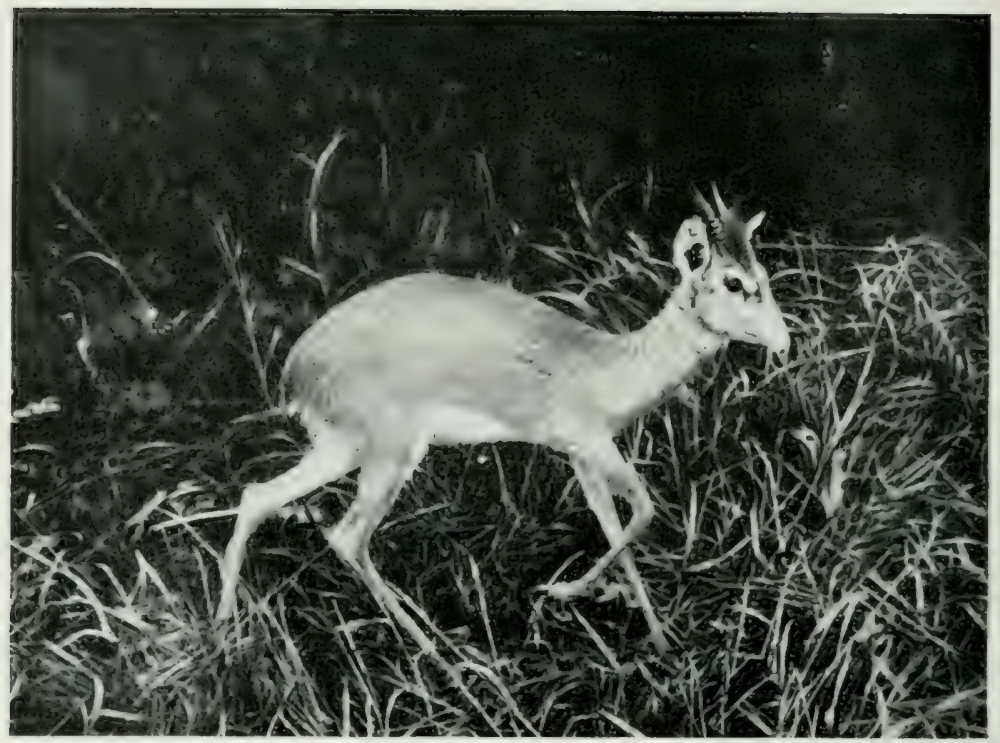

DWARF ANTELOPE IN THE CARLSRUHE NATURAL HISTORY MUSEUM.

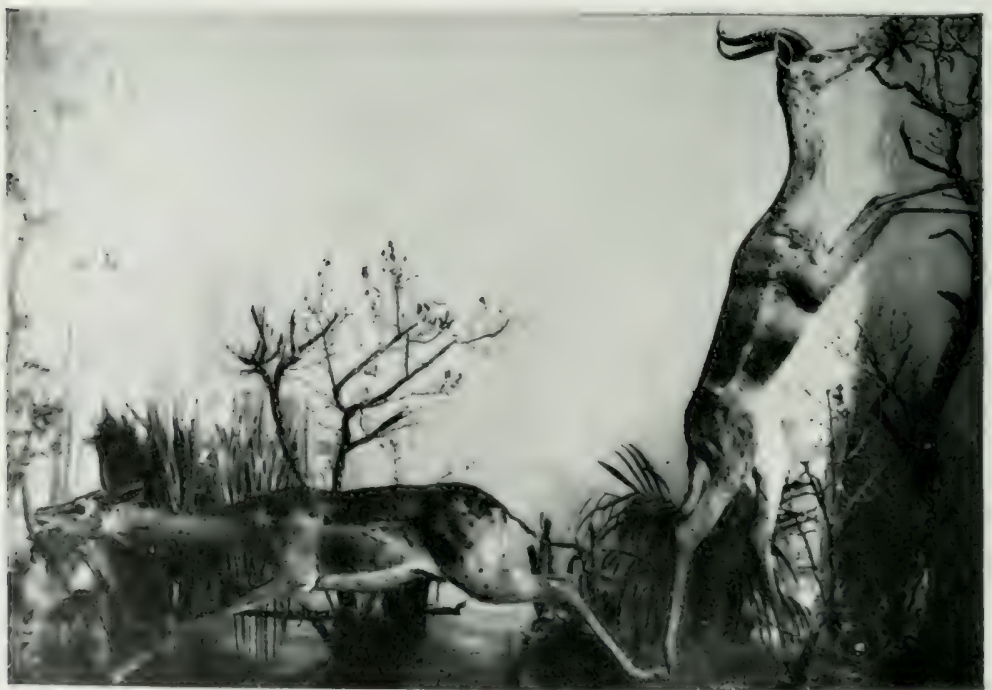

GROUP OF GIRAPFE GAZELLES (IN TIIE AUTHOR'S POSSESSION) PREPARED IBY ROBERT BANZER OF OHHRINGEN, THE ONE ON THE RIGHT IS SHOWN IN. ITS CHARACTERISTIC ATTITUDE: WHEN IBROWSING ON TKEIS OR JUUSHES. 


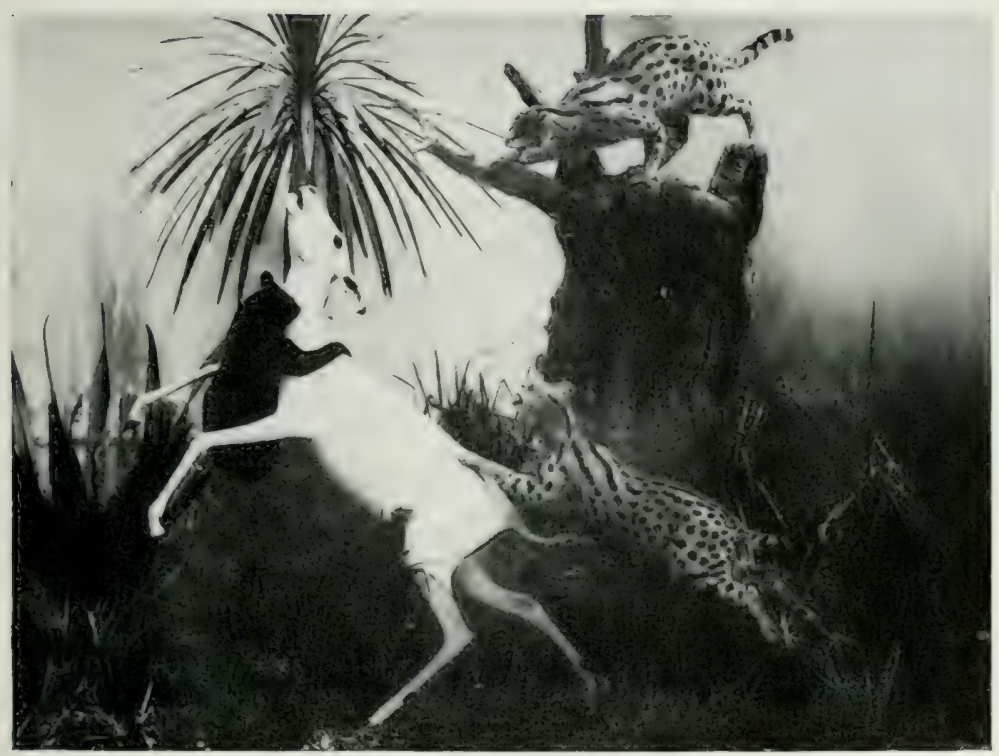

GROUP, ALSO PREPARED BY BANZER, SHOWING A SNOW-WHITE "BLACKHOOFED " ANTELOPE, ATTACKED BY A BLACK SERVAL AND TWO OTHERS.

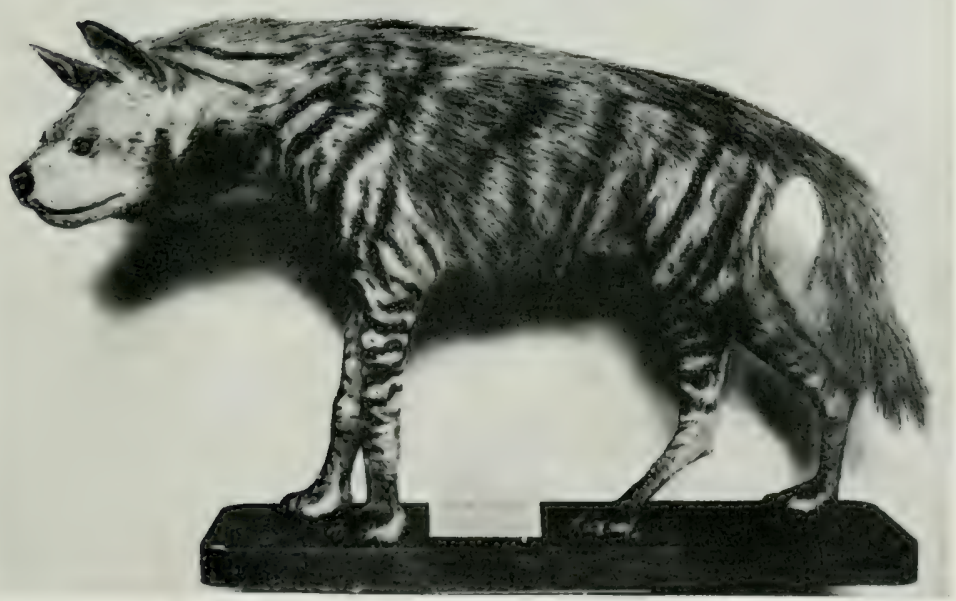

A SPECIMEN OF THE NEW SPECIES OF HYENA DISCOVERED BY THE AUTHOR IN GERMAN EAST AFRICA (HWEN SCHILLINGSI, MISCh., NATURAL IISTORY MUSEUM, LONDON). 

securing well-developed male specimens, as the hunter does, but also females and young animals in all the various stages of growth and colouring. This must be obvious even to a child, and no one will deny to science the right so to act, at least in those regions of Africa which-in comparison with India and other countries-are still untouched by civilisation, and which therefore, in their primitive unchanged condition, afford us doubly interesting results. Now supposing one has got together large collections, and has been so fortunate as to succeed in bringing them down to the coast and home to Europe. A collection of insects or of the lower animals may pass without remark; but woe to the slayer of the larger species of wild animals! These come under the description of "beasts of the chase," and now a peculiar kind of bacillus quickly develops-the bacillus of "hostility to the hunter," which, introduced into Europe from the tropics, finds here, too, a fostering soil. Let me be allowed to endeavour to find a prophylactic against this bacillus in these essays. I have already often laid stress upon the facts that such great quantities of the skins and feathers of birds are exported for the purposes of fashion, that by this trade whole species are threatened with extinction; that every individual European is allowed, without any hindrance, to send home his trophies of the chase-trophies which, with only a few exceptions, can have hardly any value for science; above all, that the extermination of the elephant in Africa is being carried out before our very eyes for the sake of his ivory ; and that all this is held permissible. But let one make collections for scientific purposes, and scrupulously hand over every skin, 


\section{In Wildest Africa}

every hide, with the horns and skull belonging to it, all carefully labelled. to some museum at home, and, according to widely expressed opinion, he is greatly to blame for the destruction of animal life.

Happily in recent years our colonial collections have been considerably augmented. An extraordinarily large quantity of material has been forwarded to the Berlin Natural History Museum, amongst others, by officials, private individuals, and members of the garrisons abroad. Hence valuable results have been obtained for the zoology of these regions. Amongst the satisfactory results of the ever increasing activity in the zoological exploration of the Dark Continent are surprising and repeated discoveries of unknown species of animals, such as the Okapi (Ocapia johnstomi) and a black wild hog, till now completely unknown (Hylocharus meinertzhageni, Oldf. Thomas). With the help of these collections, Professor Matschie, dealing with the mammalia, and Professor Reichenow with the birds, have succeeded in establishing the fact that each separate region of the Dark Continent possesses its own characteristic fauna. And most important conclusions with regard to the distribution of animals have thus been derived from these great systematic collections. My friend Baron Carlo Erlanger, the well-known African traveller, and the only one who has ever traversed Somaliland from end to end, though unhappily cut off by an early death, was able to confirm these theories, with reference to the countries he explored, by the ample collections he systematically formed. The whole science of zoology in relation to geography has been turned on to new lines of research, 



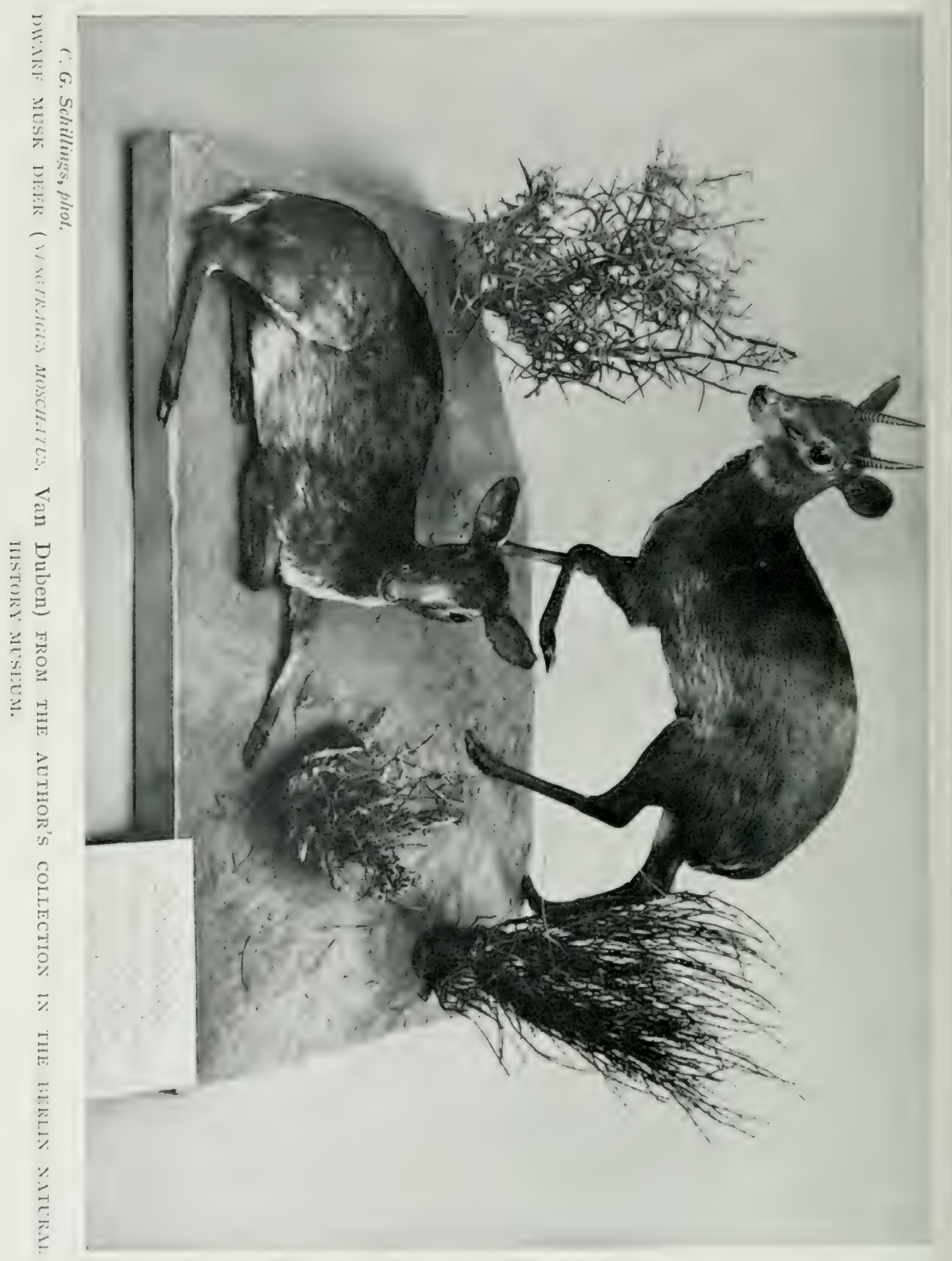



and has given the most important and most valuable results. Everything should be done to support efforts of this kind.

But in this department it is to an increasing extent the duty of our German museums to promote a knowledge of and an interest in the animal world of far-off lands by the display of ample collections, so arranged as to convey instruction. There has already been gratifying progress in this respect, but it is clear that for the development of these ideas we need more extensive, up-to-date buildings for our collections and museums. Other countries, especially England, and above all America, are far in advance of us in this matter. Our zoological gardens have the task of putting the liaing animal world before us. Happily we are doing this by far-sighted methods. To the Zoological Gardens of Berlin belongs the credit of having, to a continually increasing extent, arranged a display of the animal world in appropriate surroundings, and with reference to systematic classification and to its relations with geographical distribution and ethnological science, so far as one can assume the connection or companionship of certain species with man. There we see the disappearing species of wild cattle housed, each according to its peculiar character, in enclosures that are strictly true to nature, and artistically designed. Thus, for instance, the American bison-now hardly to be obtained for its weight in gold-is shown in surroundings that remind us of the North American Indians, these also a disappearing race. The ostrich-house takes us back to the land of the Pharaohs, of which the ostrich was once a characteristic inhabitant, as well as the ichneumon, the crocodile, and the hippopotamus. Then

VOL. I

I 6 I 


\section{In Wildest Africa}

the class of rodents is brought before us in almost poetical surroundings, that secm quite to justify the German animal stories of the Middle Ages, and that are calculated to produce quite a different effect on the mind from that of a stitily arranged exhibition of the regulation type, especially in the case of the rising generation. But on account of the difficulty of securing and maintaining certain species, and their shortness of life in close captivity, our zoological gardens can only properly carry out their programme so long as it is possible for them to continually renew their stock of animals.

On the other hand, the museums are all the more responsible for setting before our eyes the various species of animals even long after these have become extinct, and they must do this by means of works of art executed by the hand of man, masterpieces of taxidermy.

And by masterpieces of taxiderny I mean artistic groups of "stuffed" animals that will, as far as may be, show us their life and action, their ways and habits. In former times this work was left to the so-called "animalstuffer." He took a hide, filled it out with some material or other, and then, so far as he could, gave it the appearance of a quadruped or a bird. Thus one sees a stuffed hippopotamus of this good old time: which looks, not like such an animal, but like a gigantic sausage. One sees stiges or antelopes that somewhat resemble the wooden tors associated with the: Christmats boxes of my childhood, and not the particular species of animals wheh they are intended to represent-in short, wretched caricatures with neither beauty nor fidelity to nature. 



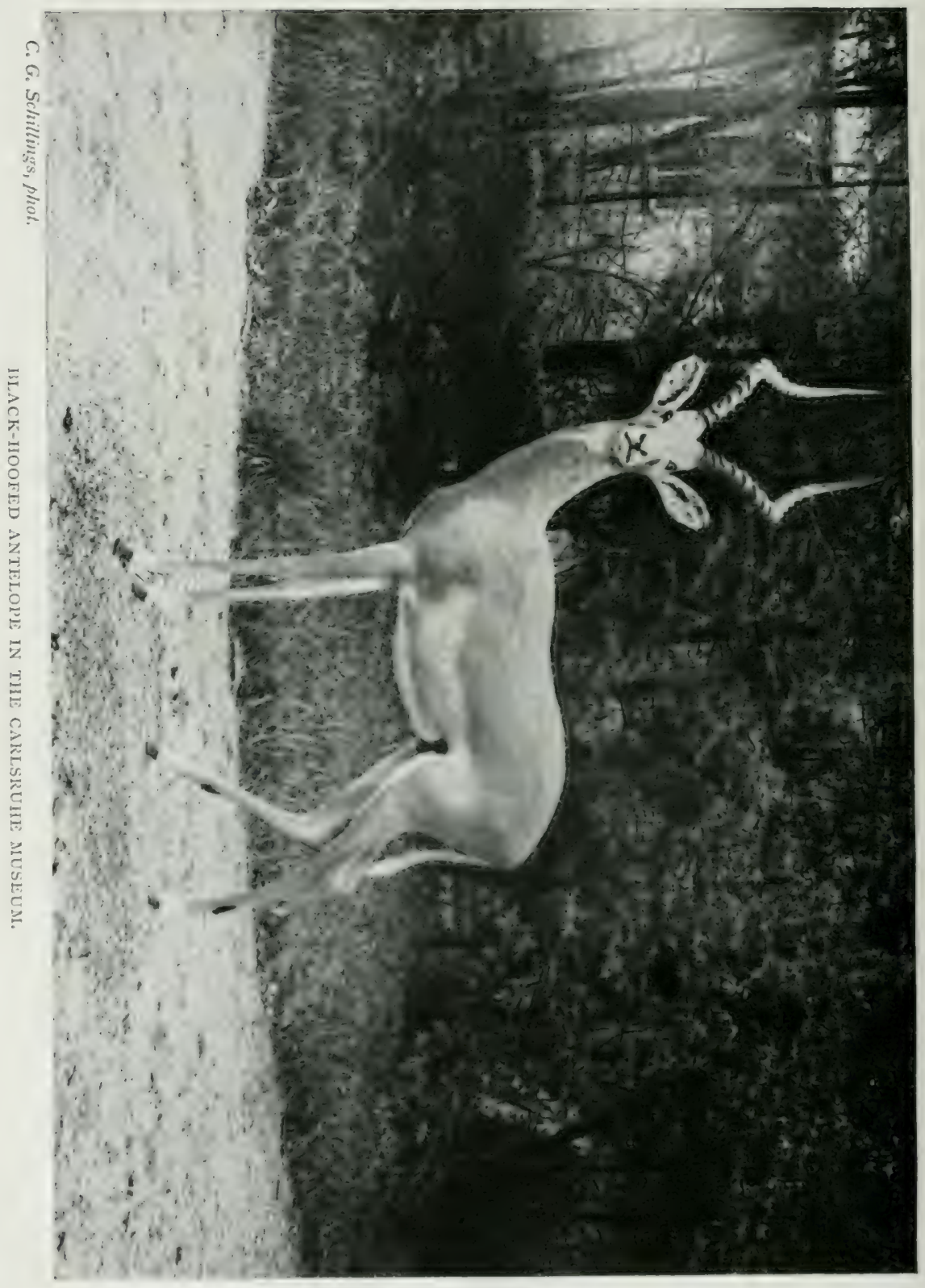






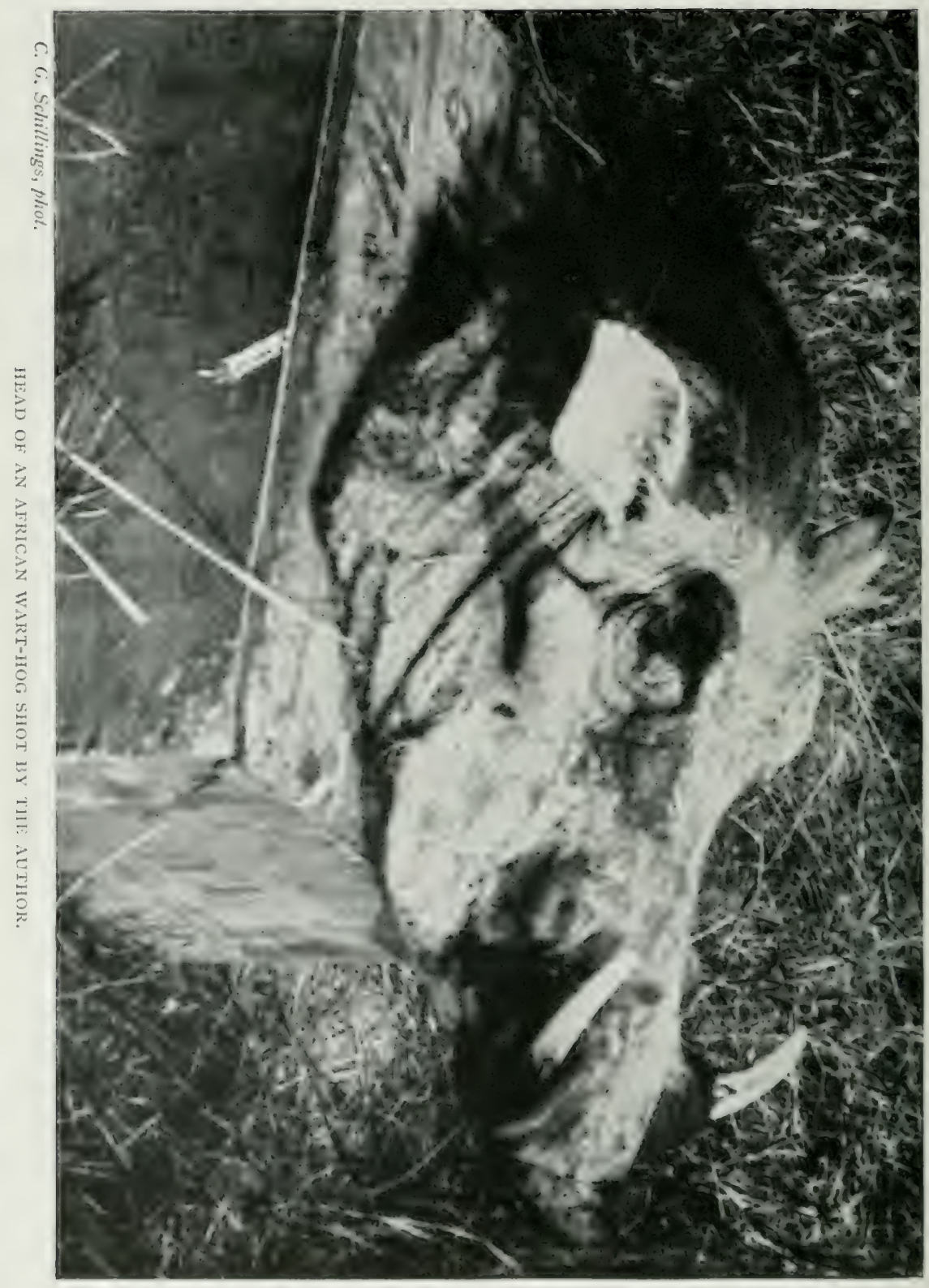




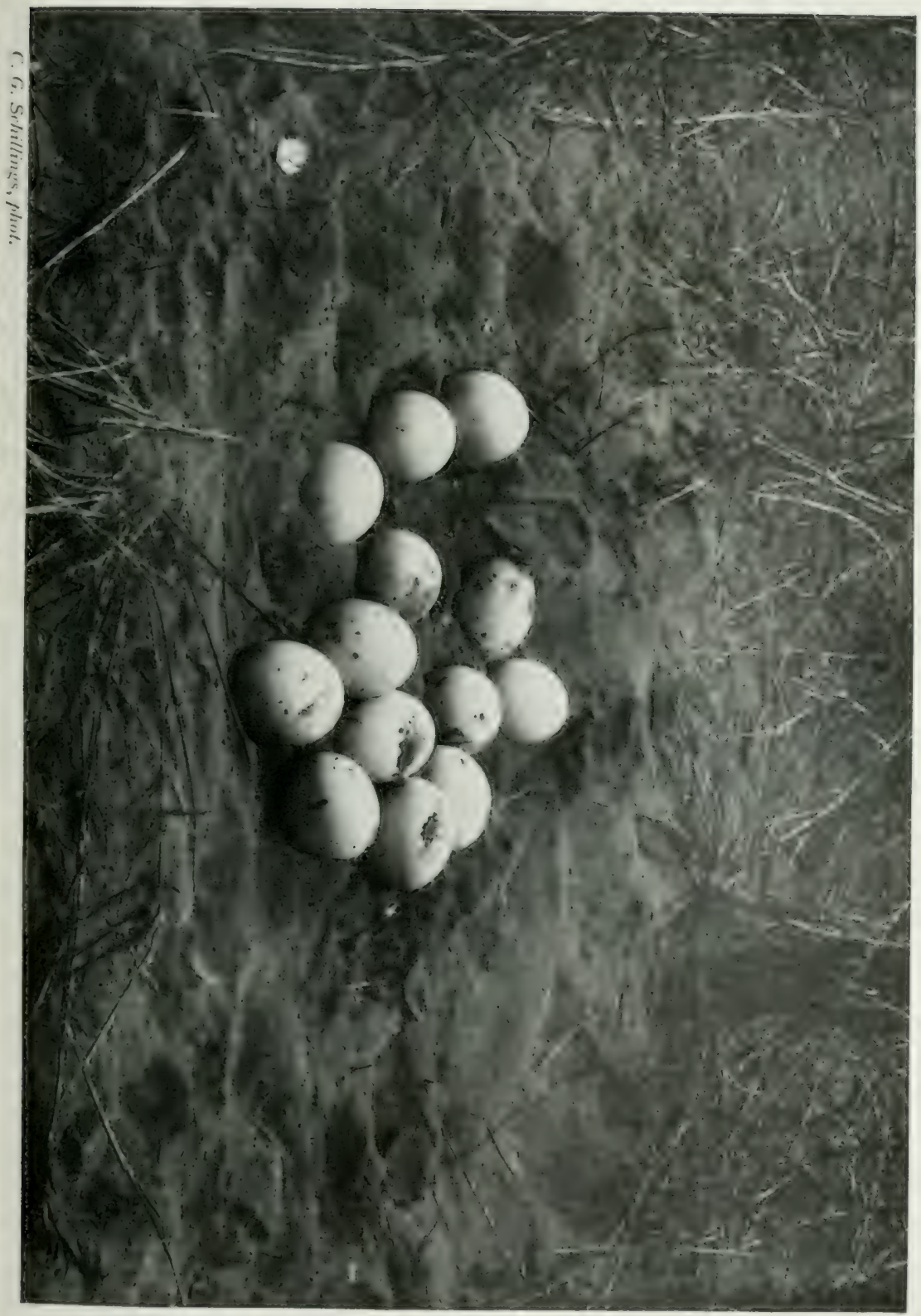



Nowadays, however, more than this must be rlone-the best must be insisted on. Instead of the "stuffer," the artist must come upon the scene. Using the methods of the sculptor, he can artistically fashion a form that will be true to life, and clothe this form with the hide or skin. Happily by these means we now find such works of art exhibited in ever increasing numbers, not only in museums abroad, but also in the public collections of our own country. But as yet this new department of artistic activity is not generally as well understood as it should be. It is still far too little valued.

What labour has to be devoted to the artistically correct setting up of even one single large mammal in a museumfor instance, a giraffe! First the animal must be hunted down in the wilderness, and its hide carefully prepared. Then, if it has been brought home in good condition, there follows a second laborious preparation, and finally the setting up. The difficult building up of the framework, and the work upon the giant beast till all is complete, require the labour of nearly a year. The very first conditions for the success of the whole are great patience, knowledge, and an ideal that is both artistic and true to nature.

Our illustrations show, in its various stages, the progress of the setting up of one of the giraffes I collected in Africa. It is easy to understand that besides artistic and scientific ability for the correct moulding of the form, various complex manipulations are required before the giant beast again stands before us as if "reawakened to life."

I have further tried to show by illustrations of another giraffe, and of a series of antelopes, down to the tiny dwarf I 71 


\section{In Wildest Africa}

antelope, how under the hand of the artist the animal world can be made to rise up again, as if waked anew to life.

All our larger museums ought to exhibit the most important and most prominent representatives of the animal kingdom modelled in attractive groups in their natural surroundings.

In America it has become the custom for private indiriduals to place at the disposal of the zoological institutions extensive collections and large sums of money. With this help they are able to produce artistic work, true to nature, works of art, the consideration of which gives the spectator an insight into the life and habits of the animal world of his native land as well as of foreign countries. Unfortunately this custom hats hardly yet been introduced amongst us.

My native city of Frankfurt ${ }^{1}$ can claim the honour of possessing, in the time-honoured senclienbers Institute (now transferred to a new home), a museum founded by private effort and private interests, where one may see collections formed for exhibition, that may be pointed out as models of their kind.

The collector of such things can partake of no greater pleasure than he experiences when, making a tour of the museums of various places at home, he sees awakened to new life the wild creatures he formerly observed and laid low in far-off lands. So I could not deny myself the pleasure of adding to this book a number of pictures of animals and groups of animals which I secured in the

${ }^{1}$ J) uring the last few years handsome groups have also been set up in the muscums of other places, such as Munich, Stuttgart, and Carisruhe. 



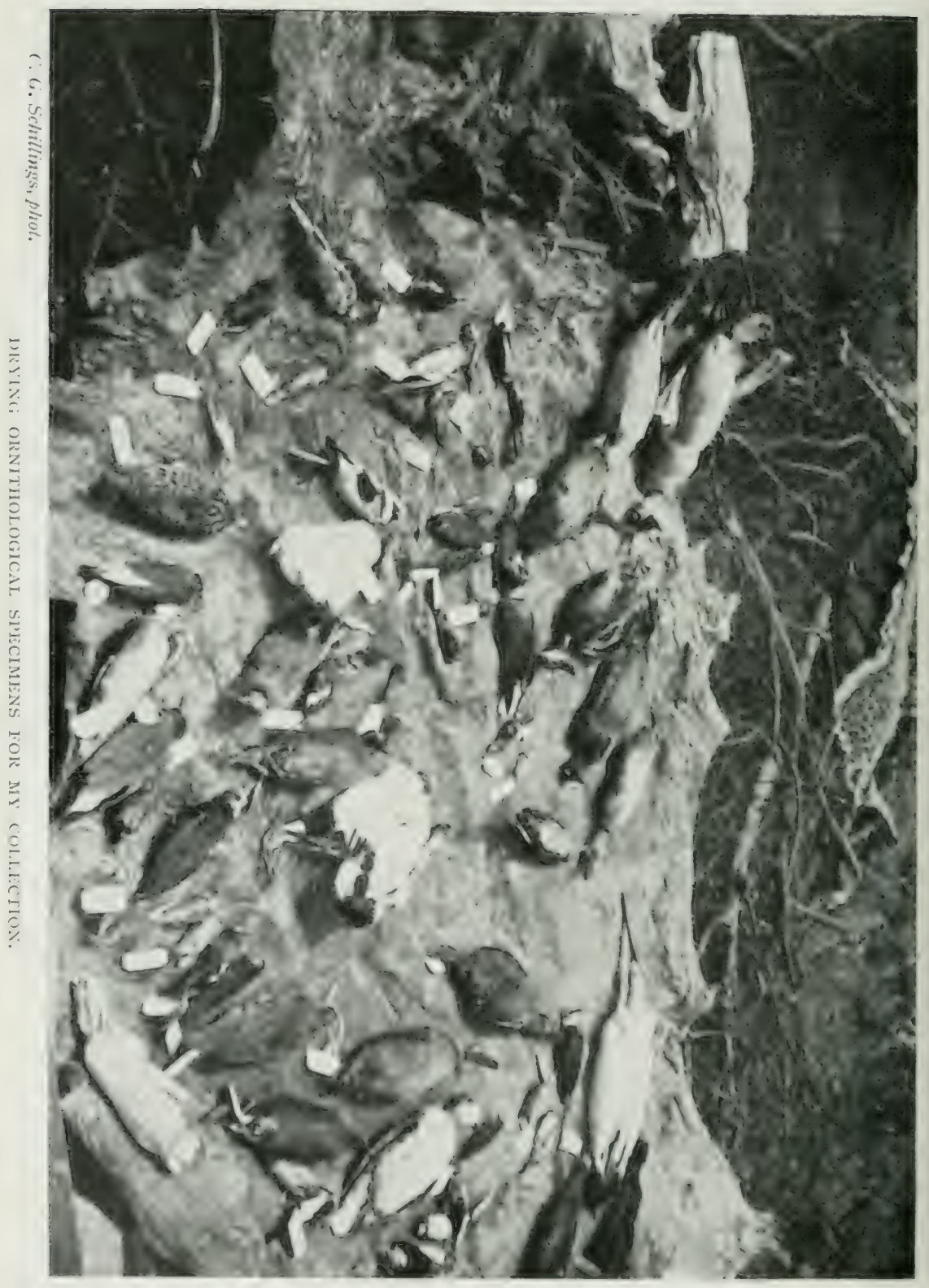




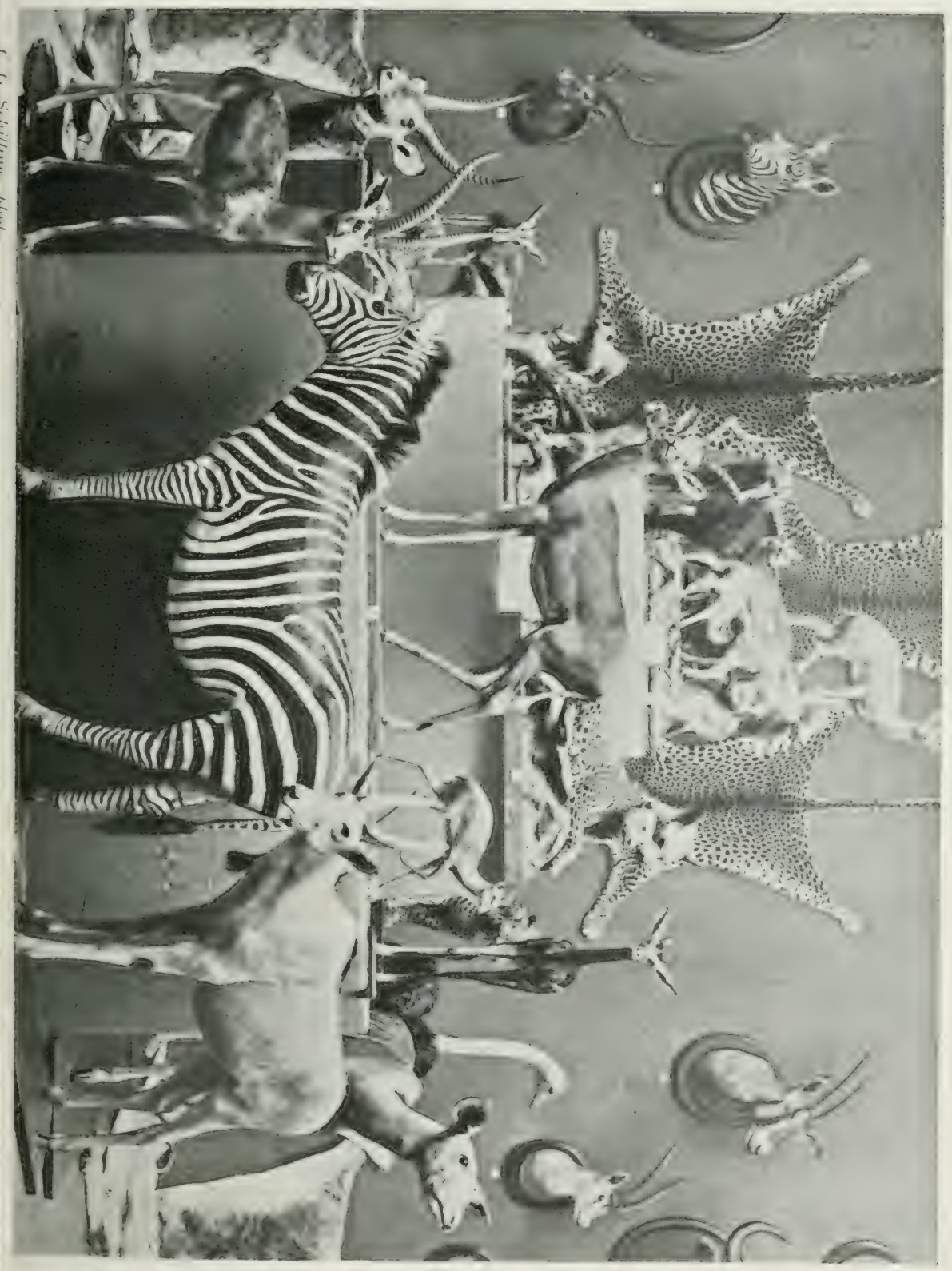



wastes of Africa, and which are now set up in various

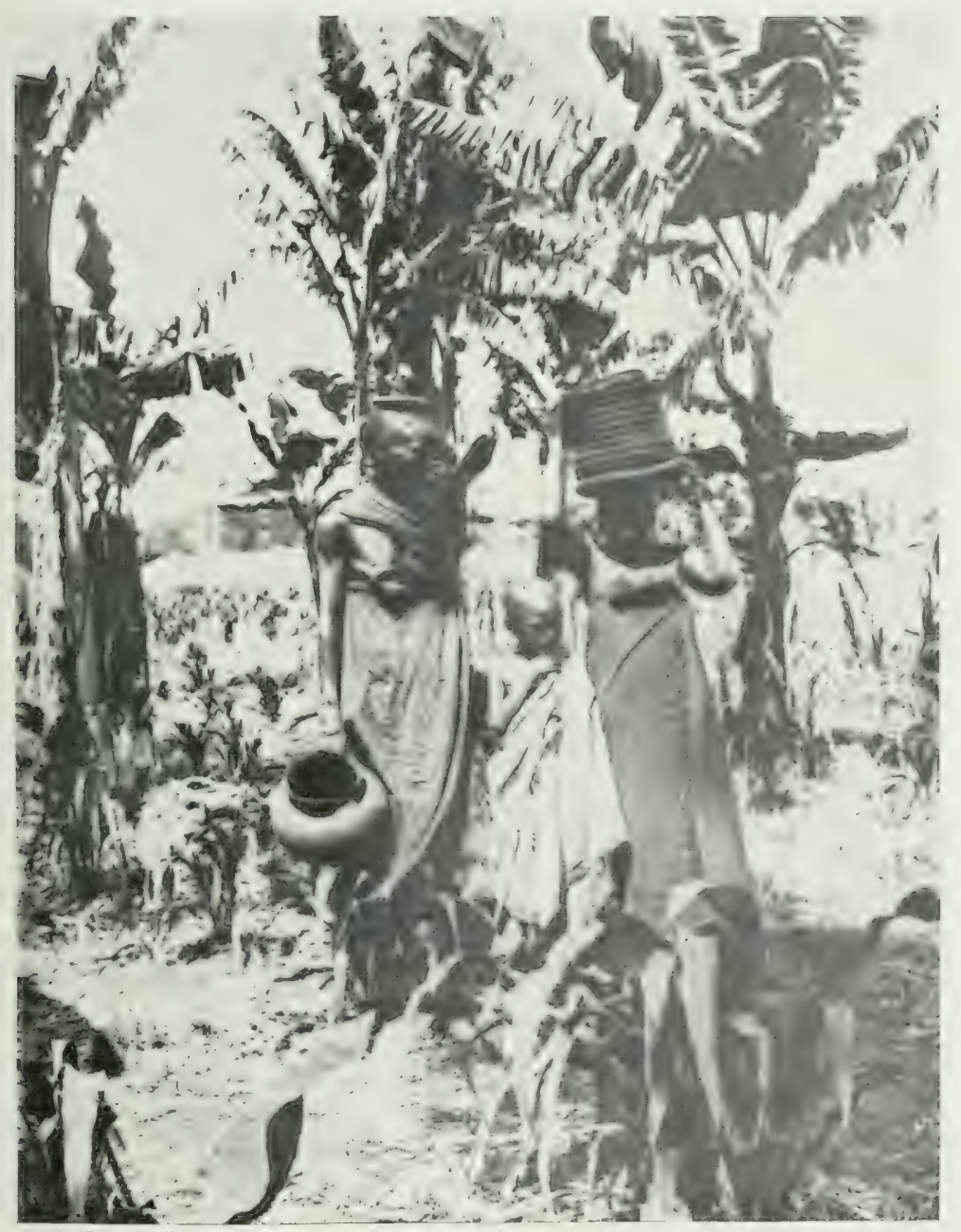

C. G. Schillings, phot

WOMEN OF THE RAHE OASIS IN A BANANA GROVE.

museums. These are trophies that must allure every sportsman. It is of course not so easy a matter to secure VOL. I 


\section{In Wildest Africa}

them as it is to hack off without any trouble the antlers or horns of some wild animal that one has shot.

Paintings, true to life, from the hands of artists, photographs taken directly from life, and finally these groups awakened, as it were, to a new life, are the means that can, and should, exert an educating and informing influence, so that all the beauty of this clepartment of created nature may not be accessible only to a few learned men, but be open to all in general. If to an ever increasing degree this object finds support in influential circles, we shall thus obtain what must be somehow obtained. In the presence of the progress of industry and civilisation no one can indeed permanently prevent by protective measures the disappearance of certain species, even though we may hope to still delaty the process of extinction by suitable regulations. But on this ground the duty that I have already inclicated becomes more clearly imperative upon us. Its fulfilment cannot fail to be rewarded, in the case of all who take part in it, by the only true satisfaction that is given to mortals, the feeling of having done all that was in any way in our power to do. 
In the high mountain regions of Central Asia, too, this spell survives, associated with the flocks of those timid creatures the primitive wild sheep, with the graceful wild goats, with the stately ibex, ${ }^{1}$ and with the life and movement of the countless huge bears of the mountains, and with a strange flora that I myself have never looked upon, but of whose existence I am as persuaded as of that of the spell itself.

It is to be found in the jungles of India, whence the tolerant natives have never driven it out. They have not expelled the animal world from its paradise. There in the region of the lotus-flower the spell may perhaps be recognised on still, moonlit nights.

It survives everywhere: in the Australian bush, in the New and the Old World, on all islands, in all rivers and waters, in the life and movement of the waves and depths of the ocean, so full of secrets everywhere; in a word, where man has not yet driven it away.

Once it lived everywhere in Germany, and even to-day it is still to be found in many places. It has its being where the mighty elk made its home on moor and marshland, and our forefathers hunted the aurochs and the bison in the primitive forest. To-day it is associated with the edelweiss and the chamois in the Alps; it has its being in the oak and beech woods, and where the green current of the Rhine flows down, or where the stag sends afar his

1 The ibex, which was once also common in Germany, has been found by Dr. G. Merzbacher in the central Tian-Shan region in the form of Thex sibirica merabcheri; and two years ago by G. Leisewitz in such great numbers that the appearance of tlocks of hundreds of them was a daily experience. 
- Sport and Nature in Germany

cry of challenge to his rival, and the huntsman makes his way over the moor.

There one still experiences the spell of the Elelescho. But everywhere, all over the world, everywhere in our Fatherland, it once lived and held sway.

We may hope that the intimate and beautiful relations that the German sportsman establishes between himself and nature in his Fatherland will for a long, long time be handed down from generation to generation, and thus result in the maintenance and preservation of the noble old spell of the woodland and the wilderness. The ideal of true Gorman sportsmanship has been developed in as high and full a sense as that of fair play in sport in England.

Both of these ideals will be judged in unfriendly fashion only by those who regard them from a distorted point of view. The English ideal of sport is winning the world to itself; the German ideal must do the same.

Coming from a good German school of sport, I consider myself fortunate in having learned to know the wonderful animal world of Africa. There is no doubt whatever that I must ascribe to the influence of this school the fact that my accounts of what I had experienced and seen met with such an appreciative reception both at home and abroad.

How wonderful is the chase in Germany! The primitive attraction for the chase must be a part of every man. One need only once have seen the excitement that seizes upon a gathering of thousands if on a sudden a hare or some other wild creature comes into sight. At such a moment, almost without exception, every one of them is on the move, without the least reflection, and even I. 8 I 


\section{In Wildest Africa}

notwithstanding the consciousness that in no case can he himself secure the prize. It is the call of a strong impulse deep rooted in men. But in our Fatherland how grandly and nobly what we mean by "true sportsmanship" has developed out of this primitive instinct!

A certain kind of organisation of the business of the chase must have been in existence even in primeval times. Those who have made a study of this department of the life of nomadic hunters in many lands tell us that tribes and groups of families hunt only in well-defined areas, and as they value their lives do not venture to pass these boundaries. I have learned the same thing by my own personal experience of the Wandorobo and other nomad huntsmen of the African plateau. It must therefore have been the case everywhere, from the times when primitive men, the cave-dwellers, berwan their struggle with the mighty beasts of primeval days, down to our own times, when the chase is more and more regulated till at last it becomes the exclusive property of the owner of the land.

As a consequence of this right came measures for game preservation both against the interference of the stranger sportsman, and as regards the wild creatures themselves. Increasing knowledge tiught the hunter that he could not kill more than a certain number of wild animals without extirpating them entirely in his district. ${ }^{1}$ Hence grew up our complex game-laws of to-day, and the general feeling

1 The Hudson Bay Company put on the market in the year IS9I $r, 35^{8}$ skins of the musk ox (Ovibos moschatus), but only 271 in the year 1901. In the year 1878 the same company sold 102,715 skins of the Canadian beaver, but only 44,200 in the year 1892 . A striking example of the results of excessive exploitation of hunting grounds! 
that our hunting grounds should be used in as intelligent a way as possible. In Germany this problem has been solved to a remarkable extent. German sport has an important influence on the welfare of the people. Great numbers of our people are strengthened in body and mind by the chase, and, thanks to it, considerable sums of money are added to the resources of the country folk.

According to a moderate estimate there are now in Germany upwards of half a million sportsmen. Each year they kill about 40,000 head of red and fallow deer, about 200,000 roebuck, 4,000,000 hares, 4,000,000 partridges, and 400,000 wild ducks, in all some 25,000,000 kilograms (over $50,000,000 \mathrm{lb}$.) of wild game, of a value of $25,000,000$ marks $(£ \mathrm{I}, 250,000)$, and forming nearly one per cent. of the total meat supply of Germany. The game leases bring in about 40,000,000 marks annually $(£ 2,000,000) .{ }^{1} \quad$ But these very sportsmen, who every year kill such a large quantity of wild animals, must at the same time be protectors and guardians of this same animal life! Strange as it may seem, many species of wild animals would have been long ago extinct if there were no sportsmen. For imperative reasons, the hunter must at the same time undertake the part of protector.

${ }^{1}$ Besides other sources, I take these data from an interesting article by C. Brock, in the periodical Die Jagd. This writer estimates the area devoted to the chase in the German Empire at 54,000,000 hectares; the number of shots fired in a year at game at $16,000,000$, besides some $6,000,000$ shots fired at animals that are not game. He rightly notes that for the individual the whole business of sport is a losing or non-productive occupation, but one of productive value for the households of the country folk, as about I $30,000,000$ marks are annually spent upon it. 


\section{In Wildest Africa}

But this idea ought to mchude a great deal more than is now the case. As I have already said, no nation has known so well how to form a beautiful and poetical ideal of the chase and the spirit of sport as the Germans have done. But it is not to be denied that this perfect development, even in its very completeness, has in a certain sense become one-sided, in so far as sportsmen restrict their protection and guardianship to certain species of animals; one-sided, too, inasmuch as to a certain extent they reyard their mission from the point of view of a close corporation. In this there is a certain advantage, but also a certain amount of danger now that, as a result of the rapid progress of civilisation, changes are introduced in every department of life so much more quickly than in earlier times.

I Iuntsmen and fishermen desire the complete extermination of all kinds of animals that they consider to be a cause of injury to their sport. The result is the destruction of many kinds of animals that are beautiful in form and constitute an ornament of the landscape. By the same kind of reasoning sportsmen, in their capacity of landlords and forest owners, ought to demand the extermination of the wild animals that obtain their food from field and forest. Naturally sportsmen do not want this, but they should, as far as may be, let themselves be guided by higher points of view. This is the case already in many instances. For example, as an instance of zealous game supervision inspired by scientific principles, we have lately had to welcome a valuable idea of Forest Commissioner Count liemstorff. Iccording to his plan, small libels that will mot annoy the animals (the so-called "( I 84 
are attached near the ears of young roebucks and red deer. Thus their resting-places, their movements, their growth, can be carefully observed. . . We are, therefore, actually living in a time when to a certain extent each individual head of game is numbered!

Interesting and valuable as such measures may be, should we not extend our loving care also to the animals that, though they are not reckoned as game, yet adorn and give animation to the land we live in? Some great landlords have given a bright example of progress in this direction. Thus in Hungary there are sporting estates on which wolf and bear are not completely exterminated, and in Germany estates on which the fox is spared to a certain extent. The result has been to the advantage of stags' antlers and bucks' horns on the estates in question. English landlords allow a free home to a pair of peregrine falcons or eagles, so as not to allow these beautiful birds to be completely extirpated.

From these examples it is clear that there can be various opinions as to the view generally taken with regard to "predatory animals." If there is not merely a selfish protection for game animals, but also protection for the other mammals and birds, we shall thus preserve from extinction some of the glorious forms of the realm of nature, and prevent their being sacrificed to narrow interests. There is food for thought in the fact that (as I have often had occasion to observe in Africa) in primitive countries there is to be found an astounding abundance of animal life. Since prehistoric times man has been cngraged in hunting with his simple wivatons without. on 185 


\section{In Wildest Africa}

the whole, arery much diminishing the mumber of animals. A striking proof that the destruction of wild life is the work of the Europeans themselves, and of the native hunters carrying firearms under their authority, is afforded by the fate of the North American buffalo, the whales, walruses, and seals of the frozen seas, and finally by that of the elephant in certain districts and of the South Ifrican fauna taken as a whole.

We should not therefore act so rigorously in the proscription of our so-called "predatory" animals. Yet, for instance, my near neighbour, Freiherr H. Geyer von Schweppenberg, has lately shown that our pretty water-hen (Gallimula chloropus, L.) can do a great deal of damage to grass and corn.

In South Africa what are called "poisoning clubs" have been organised, which aim at the extermination of "noxious animals" by poison. The use of poison ought to be entirely forbidden by legal enactments, with the exception, perhaps, of its administration for scientific purposes. The strychnine canister-the use of which ought only to be allowed, and that in exceptional cases, to those who are making scientific collections-is now making its appearance everywhere all over the world. I have had news from the most distant countries of its employment, unhappily with far too great success. ${ }^{1}$ It is already some time since the last Lammergeier of the German hill districts fell a victim to it. It is thinning to a frightful extent the numbers of the bears in Eastern

1 Professor Haberer lately found strychnine in use in various ways in many places in Eastern Asia. 
- Sport and Nature in Germany

Asia and other countries, though these are quite harmless to man. But in our Fatherland a completely organised "poison business" has grown up, which is a very serious matter.

I should like also to advocate strongly the legal prohibition of the use of pole-traps, to which all our owls and birds of prey fall victims.

If we go on as we are going, the time cannot be far distant when we shall have to strike out of the list of the living several interesting members of our native fauna. In North America, in recent times, the following species, amongst others, have some of them become extinct, others extremely scarce: the Californian grizzly bear (Ursus horribilis californicus), the San Joaquin Valley elk, or wapiti (Cervus nannodes), Stone's reindeer (Kangifor stonci), the prongbuck or pronghorn (. Intilocapia americana), the Pallas cormorant (Phalacrocorax perspillicatus), the Labrador duck (Camptolaimus labradorius). the ivory woodpecker (Campiphilus principalis), the scotar (Aix sponsa), several other species of birds, and finally the American woodcock. This last falls a victim chiefly to professional hunters, who are accustomed to kill it by hundreds in its winter quarters.

"This list could perhaps be extended," Mr. R. Rathbun, the Secretary of the Smithsonian Institute (whose kindness I have to thank for this information), adds at the end of his letter.

His communications have also been of special interest to me because they awoke in me old recollections. In the 'forties of the past century my father received a letter 
from North America in which he was informed that on ground over which the New York of to-day extends, one could shoot in a single day hundreds of woodcock. I myself, in my young days, used to take care of a beautifully coloured parrot, of a kind that since then has been almost extirpated, and is hardly to be obtained any longer. Connums carolincnsis is the name of this beautiful species of parrot, which also appears on the list of extinct animals of North America. There, too, men have begun to give strong practical expression to the movement for animal protection. In sanctuaries like Yellowstone Park there is complete protection for all animal life, including beasts of prey, and the bears have become so tame that they allow visitors to come within a few paces of them. Count E. Bernstorff, who received permission to shoot one of the few bisons still preserved in the State of Wyoming, says: "One might take the way in which the animal life of America is protected as an example in securing still better preservation for the survivors of the primeval wild life of $A$ frica. One must acknowledge that the Americans and their noble President, a brave sportsman, are now doing all that is possible in this matter."

President Roosevelt, in fact, has come forward manfully in the lists as a champion of widely extended protection for all the beatuties of nature, and especially of the animal world. He endeavours by his words and writings to work effectually for these great and noble ideas, which bring to all men delight, profit, and contentment. ${ }^{1}$

\footnotetext{
I See, amongst other writings of his, Outdoor Pastimes, by 'Theodore Roosevelt.
} 
- Sport and Nature in Germany

Brought up in the school of German sportsmanship, I had later on to change completely my view as to our distinction between "noxious animals" and "beasts of prey." The African wilderness swarms with beasts of proy". and yet also swarms with usc ful wild animals. The waters of Africa teem with the fish destroyers, and also teem with fish. We should not therefore act so short-sightedly and pedantically. We should not be so eager to hunt down the last fox, the last pine-marten. The nestingplaces of herons and cormorants are becoming ever fewer; the places where the handsome black tree storks build in our German Fatherland can almost be counted on the fingers of one hand; and the same is nearly true of the nesting-places of our rarer birds of prey.

The killing of a wild cat has already become an event; it is the same with the eagle-owl.

Out of the mass of literature of recent date bearing on the subject, I take a single book. In a very readable essay, Der Uhu in Bölmen, Kurt Loos shows that only a few years ago this interesting and beautiful large owl (Bubo maximus) was to be found making its home to the extent of some fifty pairs in thirty-five districts of Bohemia; now only eighteen pairs are living there, in ten districts. The author demands protection for the surviving pairs of owls, as natural objects that should be preserved, and he makes out a strong case for his proposal. Röntgen-ray photographs are among the illustrations of this interesting work, and they suggest that in times when one can do one's work with such excellent appliances, there is all the more reason for aroiding the thoughtless 


\section{In VTildest Africa}

neglect of legacies left to us by Nature from the days of its primeval beauty.

Numerous other examples of the rapid disappearance of certain species in our Fatherland might be quoted here. Unfortunately we have, on the whole, very little right to reproach the people of Southern Europe on the subject of their custom of carrying on a systematic massacre of birds; for we ourselves are always trapping thrushes and larks, and there is the shooting of the woodcock in spring. There can be no doubt that, if we would give up this spring shooting of the woodcock, this bird, which has so won the heart of the German sportsman, would breed abundantly in our forests. On sporting estates in the wooded hills in Baden I have had occasion to observe this bird nesting; and it is to be regretted that German sportsmen, who in other matters obey the customs of the chase with such scrupulous conscientiousness, do not spare this bird in the spring-time, although they are thus extirpating from their hunting grounds a bird that breeds in the woodlands of our country. The North American woodcock is in process of extinction, for it also is not spared by sportsmen in its breeding grounds, and it is just as little in safety from them in its winter quarters. It is thus one of the disappearing birds of North America, whilst our European woodcock is not so much exposed to harm from systematic pursuit cither in its partly inaccessible northern breeding grounds or in its winter abode. But it is indeed difficult to abolish old, deeprooted practices that are no longer abreast of the times. "Che vuole, signore?-il piacere della caccia!" was the 
reply of an Italian to a tourist who remonstrated with him on the subject of the extraordinarily widespread destruction of doves by means of nets in Northern Italy. The same answer would probably be given by the monks ${ }^{1}$ of certain islands of the Mediterranean, who, keeping up an old custom, kill countless multitudes of turtle-doves during their migration. These are their favourite dainties, and they also export them largely in a preserved state. So, too, it will be a difficult matter to obtain from German sportsmen the complete abandonment of their pleasant spring campaign against the woodcock. Through the very interesting experiments of the Duke of Northumberland, who had marks put upon numbers of young woodcock, it has been ascertained that large numbers of them undoubtedly spend the whole winter in England. Now, if Professor Boettger and Wilhelm Schuster are right in their conclusions, drawn from similar observations, as to the return of the conditions of the Tertiary period, and if the species of birds they observed used at an earlier date not infrequently to winter with us, a more extended protection for the woodcock ought, at any rate, to be introduced.

The continual levying of contributions on our colonies

1 On the destruction of the turtle-dove (Turtur turtur, L.) during its migration to Greece, see Otmar Reiser, Curator of the National Museum of Bosnia and Herzegovina, Materialen zu einer Ornis Balaniar. At Syra one sportsman shoots as many as a hundred in a day; at Paxos, according to the Grand Duke Ludwig Salvator, they are killed in heaps. 'The lands of the Strophades Islands are completely equipped with huge falling snares and shooting-stands for the systematic massacre of the "Trigones." Everywhere in Greece when the cry of "Trigones!" is heard, fire is opened upon the newcomers, 
of sea-gulls, to the injury of a great number of the other species of birds that inhabit our sea-coasts, should also be greatly restricted. If this is not done we shall witness, within a period already in sight, a lamentable extermination of our shore- and sea-birds. And how grateful for protection many species show themselves! Wherever it is extended to them they enliven the landscape in the most pleasing way. So, too, it has been found that certain species of gulls have adapted themselves to a kind of nocturnal life in the neighbourhood of our great commercial ports.

I may here mention as standing in special need of protection, and as wonderful adornments of our German landscape, whose preservation should find an advocate in every thoughtful man - the buzzard, the kestrel, the hobbyhawk, both our varieties of kite, the crane, the heron, the white and the black stork, the crested grebe, the water-hen, and the coot. All these enliven and embellish the landscape to a conspicuous extent, and should not be sacrificed to selfish interests.

I knew an old gamekeeper, a native of the March of Brandenburg, who throughout the course of a long life had been taking care of a shooting estate, which had grown up with him, so to speak. He protected his wild creatures, and was delighted at having a colony of storks' nests and a group of badger burrows in his woods. For long years he was able to preserve a primeval oak, the largest in the whole district, which in the year is 70 he named the "King's Oak."

To-day no birds of prey breed any longer on this 192 
estate; the primeval village of badgers is in ruins, and irreverent hands have cut down the "King's Oak." But the old man, now that his time of service has expired, never sets foot on the estate, though he is passing the evening of his life in the neighbourhood.

That was a man who had innate in him a just and reverent feeling for the preservation of the beauties and glories handed down to us from the far past, and who loved, and, so far as it was possible, guarded these wonders of nature.

Let us once for all throw overboard the sharp distinction between "noxious" and "useful" animals, and within certain limits let us protect the whole world of animal and plant life. This would be the noblest form of game preservation, in the widest sense of the word.

I venture to dwell upon these ideas here, knowing that they are shared by a large number of men and women. Amongst our German game-preserving associations we have societies that have rendered great services to the protection of our native wild animals. An extension of these useful efforts to the protection of all our native fauna and flora in general is most certainly called for by the greatly altered conditions of our time. We are gradually coming to a period when every individual wild animal will be registered by specialists and indicated in a list! And we are also gradually approaching in our sporting estates the ideal of extensive, well-kept gardens, in which no touch of wild nature will any longer be left. 
I appeal once more to the authority of President Roosevelt. He expresses the opinion that it is now not so much the question of preserving great supplies of any one species as of maintaining the primitive beauty of the forest in its wild life.

I think with pleasure of my youth, when, at a time when my father, in union with other game-preservers, founded the Jagdschutzverein ("Association for the Protection of Game") of the Rhine Province, I had the opportunity of making myself acquainted with the old state of things in this department. My native district, the Eifel, still sheltered boars, eagle-owls, wild cats, and many other rare animals living in wild freedom. The ear of the boy learned to know and to love every cry of our native fauna. Roosevelt rightly remarks that many of the cries of American animals, such as the hoot of the owl, are falsely described as unpleasant. He who knows them well comes to love them, and would not like to miss them from the general concert of animal sounds. Here in Germany, too, we have evidence of this to a gradually increasing extent.

The German sportsman ought to give a shining example to those of other lands in this matter of the protection of all the dwellers in his hunting grounds. To his care is entrusted the whole German fanna in its widest extent. To secure the preservation of this splendict work of nature here in Germany is an enterprise that will earn the gratitude of every lover of nature, the thanks of millions of men. The German sportsman, as the chosen guardian and keeper of the wild life of his 
native land, must also become the protecting lord of all its animal and plant lite; he should maintain his own estate in its primitive condition to the fullest possible extent. But to his estate, in a wider sense, also belongs the velt of German Africa, 'still so rich in wild life. Here, too, the German sportsman should take up the position of guardian and protector.

The well-known English writer Clive Philips-Wolley says that happily the old English sporting spirit is not dead; that the farthest and wildest hunting grounds of the world, a visit to which demands the greatest energy and courage, are still sought out by men of the English race, as in earlier days. England owes a great part of her colonies to men, eager for enterprise, who as hunters penetrated into unknown wildernesses; and the English hunter has, thanks to his courage and determination, always played a great part among strange peoples. The reckless conduct of travellers in far-off countries and among strange tribes is often sufficient to give a whole nation a bad character in the eyes of these people, while a right bearing may make it appear worthy of their admiration. Philips-Wolley further points out that the taking of "big bags" of game in far-off hunting grounds ${ }^{1}$ should not be considered merely from the point of view of stay-at-home people, but from the point of view of those who have special knowledge of the districts in question.

The time has passed when far-off lands were secured

3 Expeditions in uninhabited districts have sometimes been entirely supplied by shooting wild animals. 
in this way. But I would wish for the German sportsman that he may, so far as is possible, visit the splendid hunting grounds that he can now find in the German colonies, and there become familiar with the chase in forms that our homeland can no longer offer to him. The more brethren of the green-coated guild go abroad nowadays, and bring us tidings of the fauna and of the hunting grounds of the German colonies, the more will our knowledge of this difficult subject be enlarged, and we shall be in a better position for working out practical protective regulations for the preservation of these splendid hunting grounds.

And what a deep charm for the hunter there is in pursuing the chase in such regions! It is true that circumstances have so greatly changed in a few decades of years that the old hunters-say those of fifty years ago--would probably not be able to take the same deep delight in the sport of to-day that they felt in their own time. It was quite a different matter to go out to meet the dangerous wild beasts of Africa with the simple weapons, the muzzle-loaders, of that time. True, the African hunters, whom Professor Fritsch made acquaintance with in Cape Colony about the time of the 'sixties, already possessed long-range weapons. They used "small-bore rifles" firing an elongated bullet that carried up to $i, 500$ yards. These rifles were fitted with ivory sights and silver sighting-lines, for shooting at night. A hunter named Layard was at that time famous in Cape Colony for having brought down an ostrich at $\mathrm{I}, 750$ yards! 
Let us follow for once the wanderings of a hunter in East Africa, and give ourselves up completely to the charm of such a sporting expedition. No one is better fitted for making himself acquainted with lands that are remote, difficult of access and unhealthy, than the sportsman, who, even in such tracts of country, can find enjoyment. Besides the greater or less delight that the chase itself affords, much besides that is beautiful and desirable will present itself to him.

When he has got his caravan together he enjoys in the first place the feeling of primitive untrammelled life in the wilderness. We see, indeed, how amongst those who belong to the most highly developed of civilised nations, even in our own days, the need of some dim reflection of this life makes itself plainly felt. Thus, especially in America, we see how many dwellers in cities spend some days out in the woods and prairies, in order to enjoy there for some time under the tent the pleasures of camp-life.

In a land which, like Africa, harbours all kinds of dangers, we must leave all hesitation behind us. In fact, the charm of danger must be an attraction to the huntsman. He has to justify the confidence of his followers and of his comrades. The natives who come in contact with him will by his bearing and conduct form their judgment of all his compatriots, and of his native land as a whole. So there imposes itself on him the duty of regarding himself as a representative of his nation. Though he is justified, if it comes to that, in clefending his life even by bloodshed, he will nevertheless seek, as far as 


\section{In VTildest Africa}

is possible, to enter into friendly relations with the native tribes. In many districts of Africa the European will traverse, with altogether superior weapons in his hands, countries whose inhabitants still fight with nearly the same weapons that were borne by prehistoric tribes. But notwithstanding this, he must remember that his superiority rests chiefly on the prestige that the European possesses in presence of the black man. But this prestige will not suffice, especially at night, to keep off all attacks. It is therefore necessary that proper precaution should be the rule. This is in the long run not such an easy matter, for generally in the midst of apparent peace no one will think of the possibility of an attack. But it often takes place without warning; and thefts at night will also sometimes happen. In short, the middle course between necessary precaution and needless nervousness is not always easy for the traveller to hit upon.

But all this, to a great extent, adds to the charm of that wild caravan life. There is something endlessly alluring in thus going out into the open country with all one's belongings, pitching one's camp by some pleasant place where there is water, and under shady trees, and wandering, free as the birds, wheresoever the desire or wish of the moment leads one. Of course, if no shady trees are to be found, if the water tastes strongly of natron, or looks more like pea-soup than clear spring-water, if swarms of mosquitoes annoy one in the night, and flies and other insects in the daytime, all this must be put up with as a part of this wild life. Free as the birds, we can indeed choose our way, but with the everlasting 198 
restriction that it lies where water is to be found, and that we can secure supplies.

But with a little good-humour one can get over all this, especially if one keeps before one's eyes the fact that there are many worse things here, such as malaria, dysentery, and all the other numerous trcpical diseases with which these lands are so lavishly supplied. But we could not find greater enjoyment in the primitive beauty and charm of this wilderness, even if all this were not so.

It is true that the hunter in Equatorial Africa cannot obtain such splendid trophies as the stag's antlers, that marvellous structure built up by an animal organism, and, according to Röhrig's striking researches, renewed again year after year in about eighteen weeks. But instead there beckon to him other prizes-the mighty horns of the buffalo, the heavily knotted horns of the eland, the strong spiral horns of the two species of kudus, the variously shaped horns of the cow-antelopes, the swordlike horns of the oryx-antelope, all the beautiful variously shaped antelope and gazelle horns, and many others that make most delightful trophies, and will be still more highly valued the more sportsmen go to these distant countries, and the more these treasures, often so diffcult to obtain, are understood. The mighty weapons of the elephant, that glitter white in the sun, the uncouth horns from the head of the rhinoceros or the tusks of the hippopotamus, the head of a giant crocodile bristling with teeth, the plain and yet so eagerly coveted hide of the King of the Desert, and the glaringly 


\section{In Wildest Africa}

variegated skin of the leopard-all these are souvenirs and trophies that have the greatest charm for the hunter : of the greatest charm and value if he himself has taken them, and not merely (to use the sharp words with which Roosevelt scourges such practices) contracted for their capture. The German sportsman must contend for all these trophies argainst certain unsportsmanlike elements. such as the Boers, who unfortunately seem to be now exterminating the wild animals on Kilimanjaro; but they belong to the sportsman much more than to such as these. German hunters should not hesitate to take by sportsmanlike methods their fair share of the stock of big game, and in this way, as has long been the case in India and Ceylon, a code of customs of the chase will grow up in the German colonies, suited to the special circumstances of the country. In a publication by Captain Schlobach, that is well worth reading, it was recently stated that the military posts at () lgoss and Sunjo on the Masai uplanels were continually at starvation point, and, in default of other supplies, had often recently been provisioned entirely with the spoils of the chase. ${ }^{1}$ What would not German sportsmen (who contribute such large sums to the colonies) have given to be able to shoot these wild animals, and at the same time to help to spread in our colonies the idcals of the chase as understood in Germany, and to assist in the general recognition and success of German sportsmanship!

Our knowledge of the animal world of foreign lands

${ }^{\prime}$ Cf. Schlobach, Dentsch-Ostufrikan. Zeitg. I Beiblatt, io Febıuar, 1906 


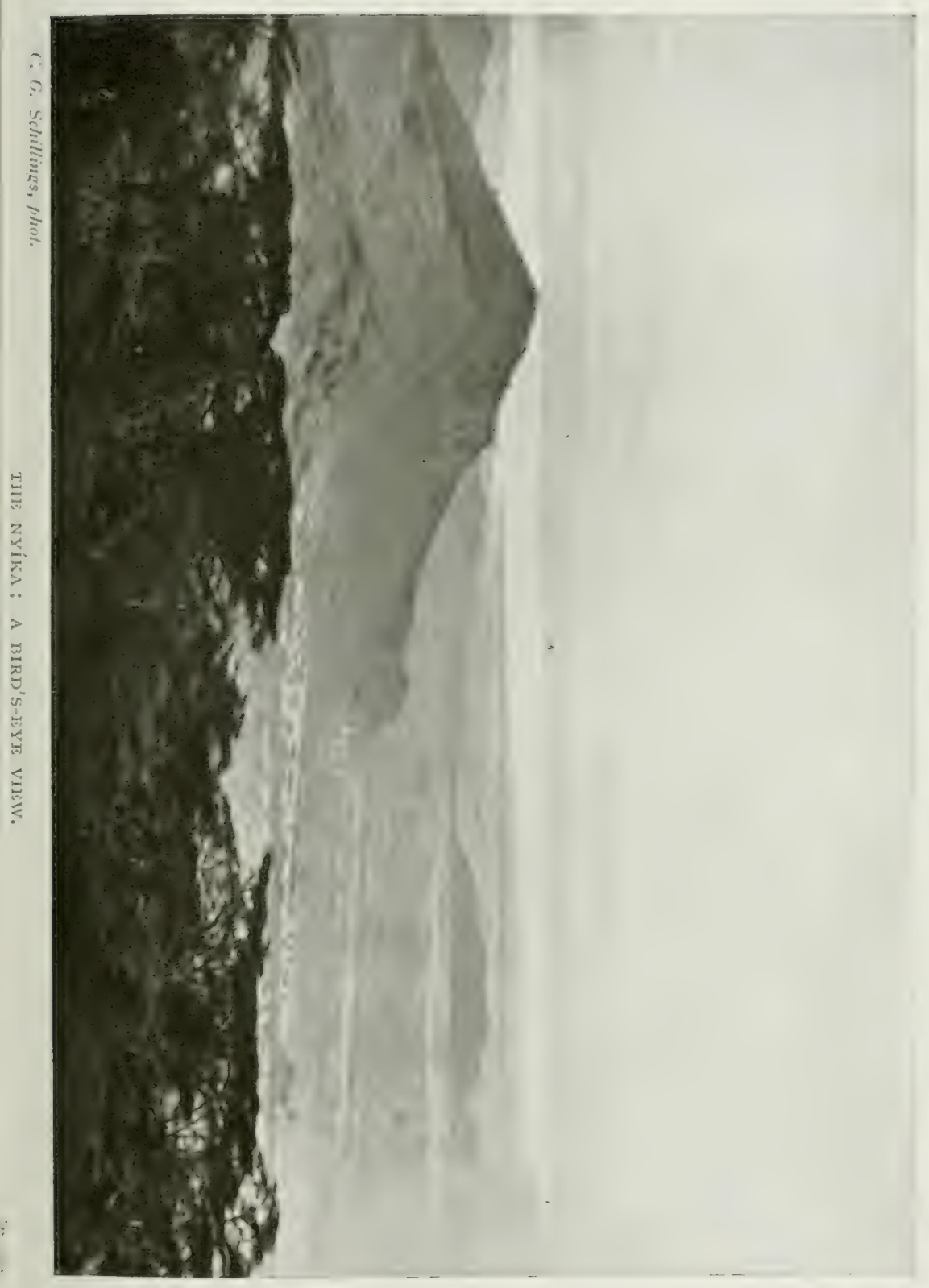



is gradually increasing to such a satisfactory extent that not only do we find a general interest taken in the wild life and the hunting grounds of our colonies, but we shall also be in a position to introduce adequate measures of protection for this beautiful fauna.

In our colonies much has been lately done towards clearing up the hitherto hidden secrets of animal life. But if one remembers how many different opinions there are, even amongst authorities at home in Germany, with regard to many of the questions relating to our home fauna, one will pass a more lenient judgment on the many sharp controversies about matters of this kind in the tropics.

But nothing of value is to be hoped for from controversial strife over divergent theories. All men who have acquired expert knowledge on these difficult matters should rather unite in a common task, and strive by cooperation to obtain some adequate result.

In the wide British colonial possessions in Africa very extensive reservations have been established, in which no one is allowed to harm the animals. The practice of making exceptions in favour of certain officials has not been found to answer, and has been given up. So now wide districts of British Africa rank as animal sanctuaries.

In German Africa, too, the authorities have tried, as far as they can, to obtain useful results by similar methods. Unfortunately serious events of many kinds are daily contributing to the diminution in numbers of the fauna of German Africa. Thus the war in South-West Africa is sweeping away the still surviving stock of wild animals as with an iron broom. 
In the face of all this, all parties concerned should take their share in common action. Our museums should be provided with the necessary material. Even if our knowledge of the African fauna has made sufficient progress, it further concerns us to exert an educating and informing influence on every pioneer of our colonies, so that he may not come in contact with that beautiful animal world in utter ignorance of it. Unfortunately we are still greatly wanting in this respect. However, in recent years a great amount of material has been placed at the disposal of the museums by our colonial officers, officials, and private individuals. Many of them have even made important contributions to our special knowledge of the animal world.

But now, whether it is a question of tracing out the hidden and unknown life and ways of that equatorial animal world that has come into our possession, or of investigating the customs and languages of races that are barely discovered, or of tracking the horrors of tropical diseases and the germs that excite them and becoming master of that miniature world of life with the lens and the microscope, or of going into the wilderness as a sportsman -the men who devote themselves to all these pursuits will be led onwards by that spell, whose name the reader guesses, the spell of unchanged primeval conditions and untouched nature!

May as many as possible of our German sportsmen go forth into our tropical possessions and yield themselves up to this spell! That which in our hunting grounds at home speaks to their hearts in the rustling of the oak and beech 


\section{- Sport and Nature in Germany}

woods and on familiar moors and fields, they will find in a far higher degree in that far-off wilderness under the German flag. Returning home, may they, working in unison, and by mutually supplying what each may lack, bring into existence some splendid memorial of the joys of German sport. 


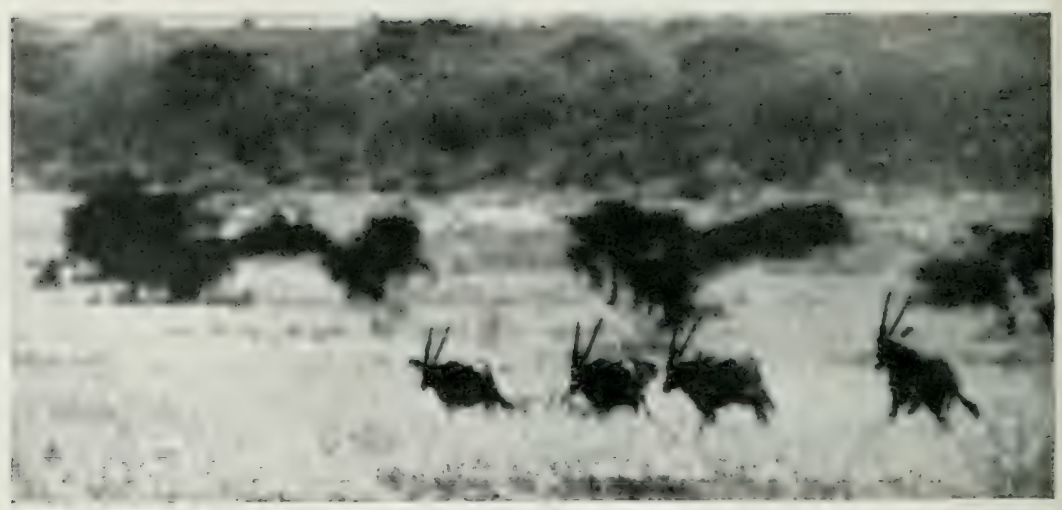

ORYX ANTELOPES TAKING TO FLIGHT,

\section{I}

\section{The Lonely Wonder-world of the Nyika}

THE endless wilderness of the Nyika presents to the wonderful that at times his senses become wearied of these changing impressions of travel, and a longing comes over him for the familiar scenes he has learned to love at home.

As though in giant characters written on its rocks, the Nyikia tells us of the conditions and the life of the past and at the same time of everyday actualities, giving us its message as well by its snow-covered volcanic peaks as in the footprints and tracks of the mighty creatures that wander through it. It is a difficult undertaking to reconstruct in fancy all the splendours that must once have presented themselves to the eye in this region. But nevertheless I will tell of what I have looked upon in the past, - of the many beautiful sights that linger in my 
- The Lonely Wonder-world of the Nyíka memory and rise up like the shadows of a mirage, — of

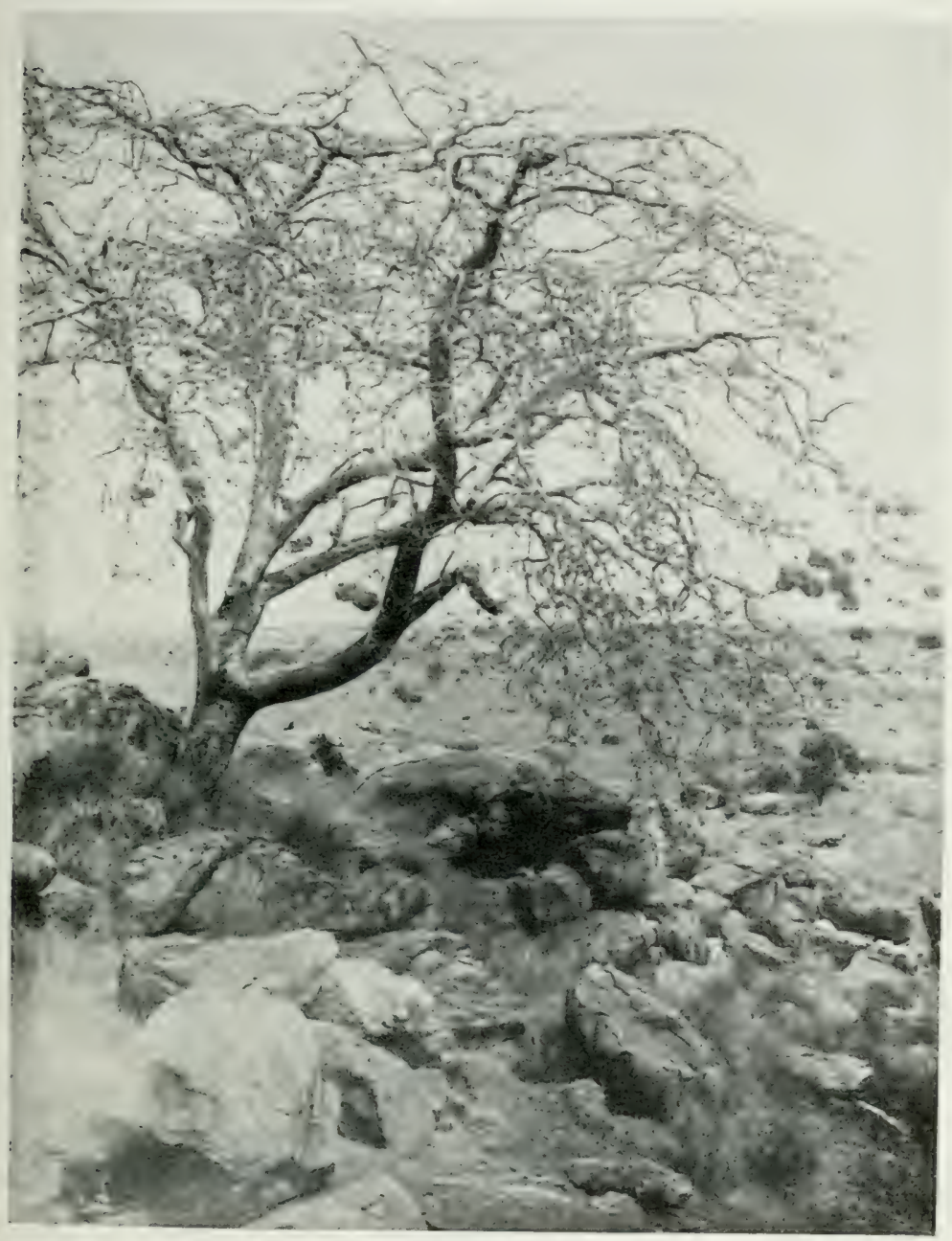

A VELT HILLOCK. THE SOLITARY TREE WAS FULL OF NESTS OF WEAVER-BIRDS.

the delightful manifestations of its moving life, coming and going on hill and in valley, as strange, wondrous, and 


\section{In Wildest Africa}

unfamiliar forms reveal themselves to the astonished spectator.

The mystery of a deep harmonious influence belongs to the mighty wilderness. It reveals itself in its full beauty to him who has strenuously acquired a love for it by making a long sojourn in it and paying to it the tribute it demands.

A stony wilderness extends endlessly on all sides, and the sight ranges without limit over the expanse that loses itself in mist and cloud. A barren stony sea, as far as. the eye can reach!

But it is not the velt or the African desert that lies below us as we rise one moment a hundred yards above the surface of the earth and the next three hundred yards and more. It is the sea of houses that form the capital of the German Empire.... In a few seconds the view takes in all the full extent of the mighty city, and then, as if in a dream, what we have just seen disappears from our sight. Borne by a breeze, of which we are hardly aware, our balloon sweeps towards the Baltic Sea. . . . It is a strange feeling thus to enjoy, thanks to our lofty point of outlook, an extended view far over the level March of Brandenburg with its teeming population all below us, a view which, old as the world is, has been vouchsafed to few mortal men. The city, with all its human life and activity, lies far below us. Its roar and tumult, that strange voice of the stony sea, has died away. We begin to make a long journey only a few hundred feet above the surface of the earth. Later 206 


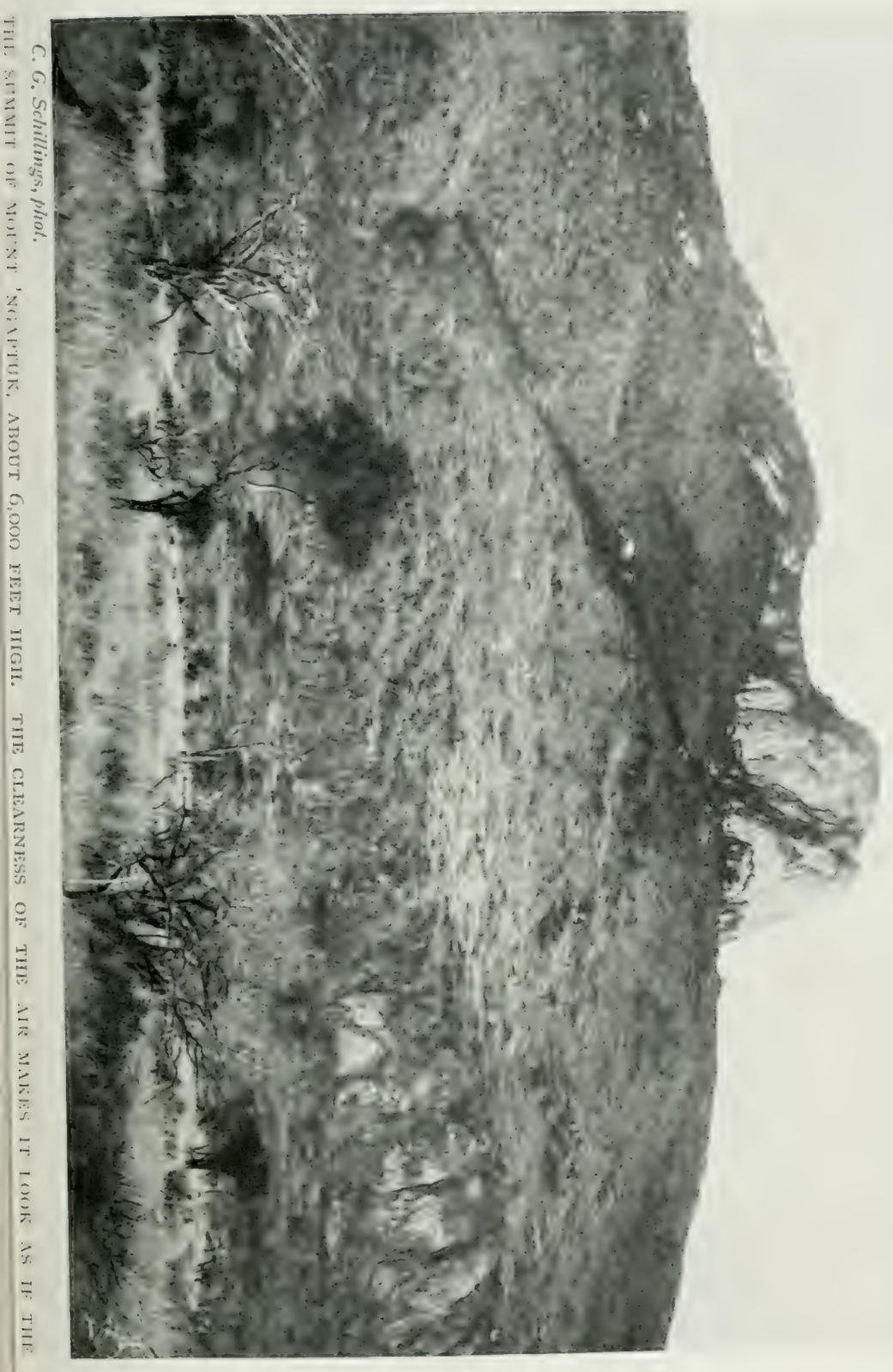



on we rise, sailing through banks and clouds to a height of nine thousand feet above the earth, but before this higher ascent we have time and leisure to take a bird'seye view of "all that creeps and flies." What an outlook over forest and plain! As we fly over them, horses grazing in paddocks, cattle on the pastures, for a moment suggest to me an illusion of the African velt peopled with its wild life. The eye, again and again fascinated by this prospect as a whole, can hardly grasp the details. Now our course is over endless open heaths, over moors and woodlands. The fleet-footed red deer, frightened by the drag-rope, look up in astonishment and stare at the strange monster, not knowing whither to turn in flight from such a menacing apparition. How the strange monster was a few hours later within a hair's breadth of burying us in the waves of the Baltic Sea is another story. . . .

How many hundred times, after I had gone back to the Dark Continent, have I wished for such a lofty observatory, an airship that would bear me over velt and desert, and from which I could fathom all the secrets of the animal world of the tropics, instead of having to travel toilsomely, fettered to the earth, often merely making step after step automatically in the blazing heat of the sun. When one day such a wish as this is fulfilled, that animal world in its beauty and splendour will have to a great extent passed away.

I must, therefore, content myself with lofty observatories of another kind, that are not unfrequently

YOL. I 209 
to be found in the Masai uplands, in the form of numerous hills and rock masses. These afford splendid views and pictures of the animal creation to the spectator who waits patiently on their summits for hours and days, and has the help of good optical instruments. What life and activity displays itself there before our eyes under-favourable circumstances! Though the wilderness may appear a desert solitude, bare and empty of all life, let only a few hours go by and the sun change its position a little, and already one sees movement under the trees and bushes that have been till now casting deep shadows. Then with measured steps, prudently regardful of their safety, all kinds of animals come forth to graze. We see the different wild species appearing, at first a few individuals, and soon in greater or smaller herds.

How far the eye carries in this clear transparent atmosphere, and what a wide tract of country we are able to overlook! In this tropical brightness, after wecks and months, and even years, I could not get rid of the perplexing illusion as to distances. The tract of country that my sight could command seemed always much less extensive than it really was. And again, we were continually being misled by shimmering rellections of the: air, so that we took gnus for clephants, ostriches for rhinoceroses, zebras for wild asses, and we might even hold to our mistaken view for a considerable time. He who wants to watch the living animals in this way from a lofty point of observation, must be able to keep on persistently for hours. Thus only will the scene piece 


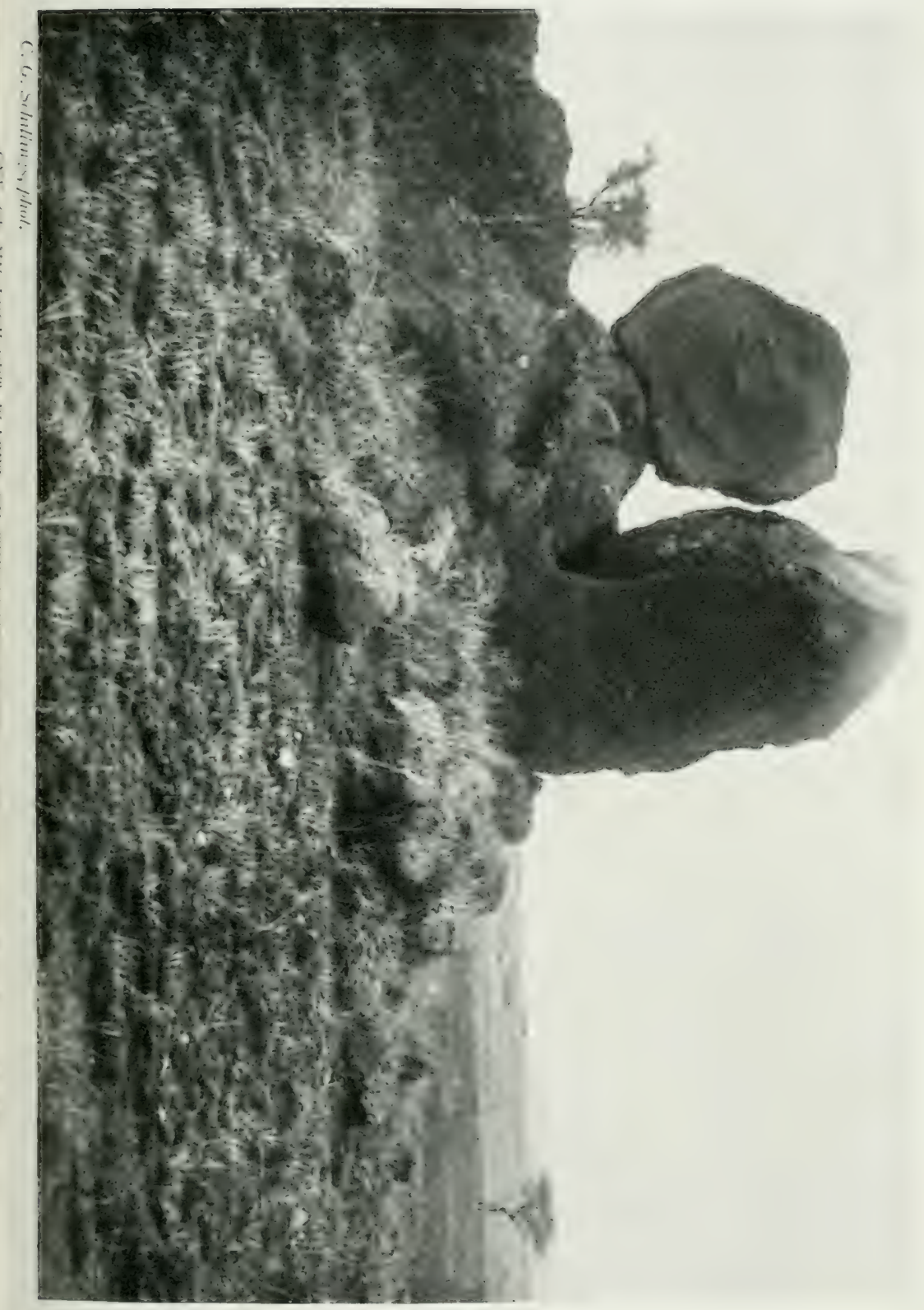



- The Lonely Wonder-world of the Nyíka

by piece become familiar to him. Thus only will all the moving life below him very gradually combine into one splendid and intelligible picture.

On the way to my look-out hill I pass thousands of the tracks made by wild animals.

At the very outset, the traveller from northern lands sees a most surprising sight in those hundreds of thousands of tracks made by wild animals, and faithfully preserved for weeks and even for longer periods in the dry season on the plains of Africa. The giants of the animal world leave behind them their mighty footprints, often for nearly a year, holes in which a man will sometimes break his leg. But the footprints of the smaller animals also last a long time on velt and plain. And the language of the wilderness rises to a most effectual appeal to our senses when these tracks are associated with the marked tarry scent of the waterbuck in the bush, the breath of the great wild herds on the plain, the strong scent left by elephant or rhinoceros in the primeval forest and in the sultry thickets, and the scent of the buffalo among the reed-beds.

There is often a chaos of tracks, a wild maze of paths trodden flat as a barn-floor, crossing each other, and then again uniting, so that the idea of tame herds, mentioned before as at times suggested, can no longer hold good.

To-day we have again waited patiently to see the wilderness gradually come to life in the hours of the afternoon. And we have not been disappointed.

Out from the shadows of scattered groups of trees 


\section{In Wildest Africa}

there march great herds of the white-bearded gnus, that remind one so of small buffaloes. Slowly they make their way to the more open grazing ground and disperse themselves over it. But careful watch is kept by a few of them-the bulls that lead the herds, experienced old fellows! Under their guardianship the herd feels itself perfectly safe. There is also an unusually large drove of the wonderfully graceful impallah or black-tailed antelope. What a remarkable contrast is presented as the herds mingle together! The gnus, strongly built, haughty in their bearing, conscious of their strength against all animal foes, stand out wonderfully amongst their almost too graceful comrades, the impallah-antelopes. We can plainly distinguish that the females and those that are accompanied by young ones keep more together, while the bucks of the impallah-antelopes keep apart and look after their safety.

Now a dark black mass slowly separates itself from a large group of trees. It is followed by several forms that do not so easily catch the eye. Our field-glasses tell us that a small flock of ostriches has come to mix with the wild species already noted. Now there are perhaps well over three hundred head of these three kinds of wild animals united together in one gathering. They are used to come together in the most friendly way, without apparently taking much notice of each other. For a long time the sight of these creatures, all so different, holds us fascinated. But our optical instruments must restlessly explore the distance for new sights of the animal kingdom; and at the same time there are even 


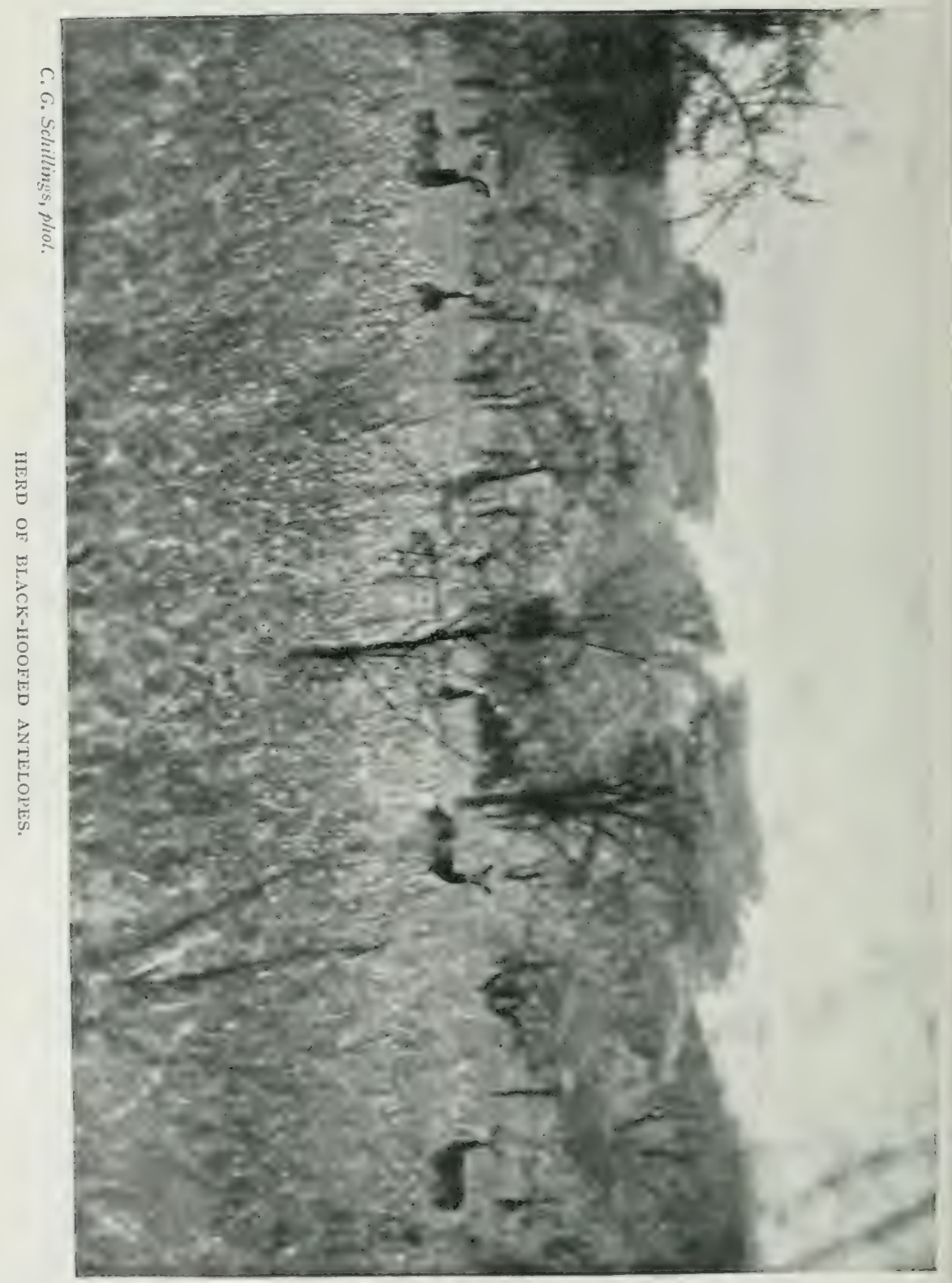




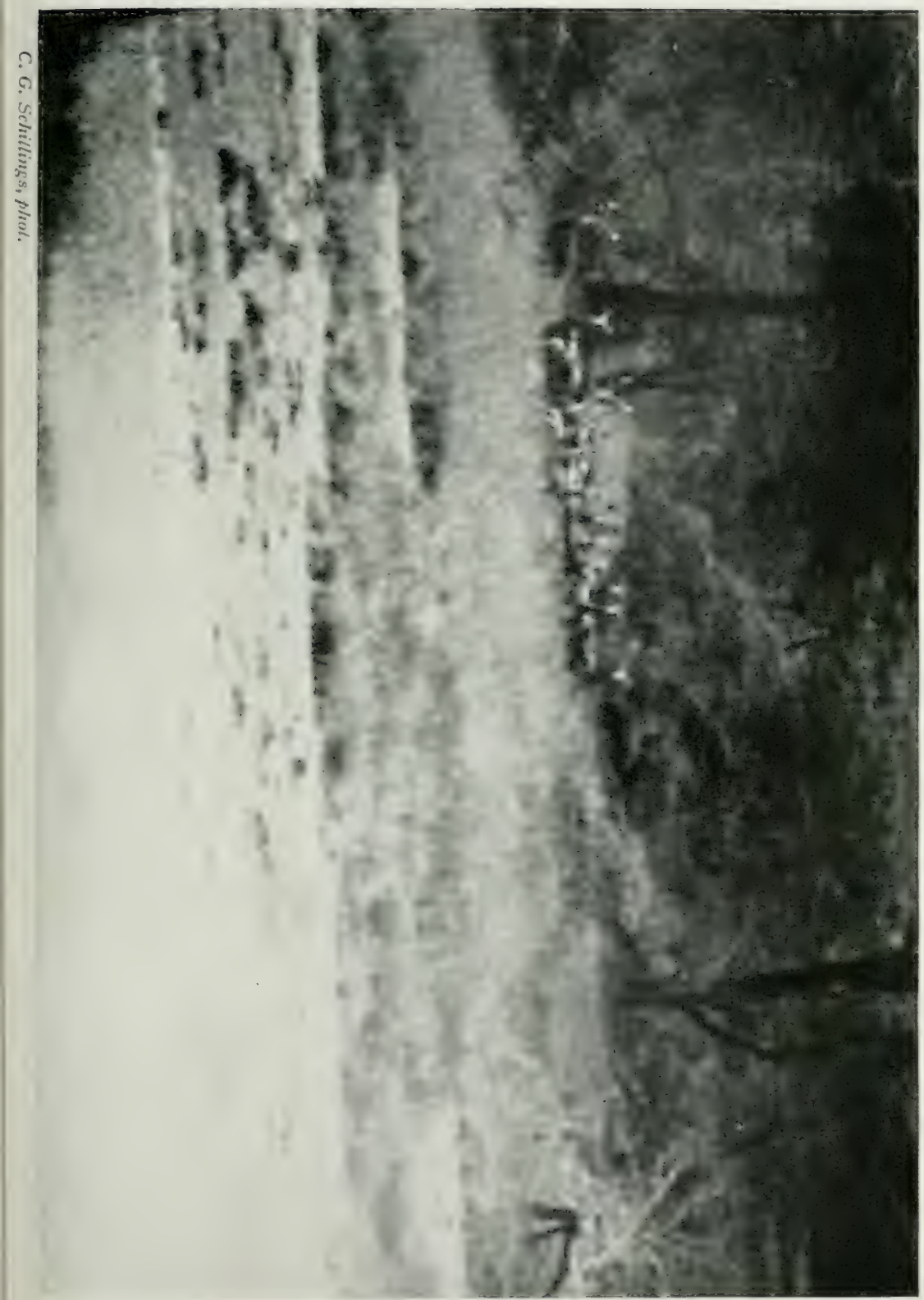



better instruments of investigation at work-the eyes of my black companions.

"Pharu, bwana!" now whispers one of my men, and points cautiously with his arm down to a certain point on the plain. His caution, however, is not necessary, for it is at a distance of at least a thousand yards that his sharp eyes have distinguished the outlines of two almost invisible rhinoceroses that are moving slowly through a group of acacias. What an effect that word "pharu" has upon me! For once more there has come close to me one of those strange; mighty beings that really belong to a time long passed, and which, like the elephant, the giraffe, the zebra, the gnu, and a few other forms, lend to the wilderness the charm of primeval days. Naturally still stronger is the effect of the cry of "Tembo!" on the hunter and the watcher amid such scenes. "Elephant!" This name electrifies even the weariest traveller. But when the word is "Twigga!" ("Giraffe!")-even here in Europe the strange, slendernecked creature, moving in some acacia wood all flooded with the sunlight, comes up bodily before me-bodily and plainly to be seen, but alas, only in imagination!

After trying for a minute, I succeed in getting the massive creatures sharply defined in the middle of the field of my glass. But the clear view of them is something that comes and goes. Several times it looks as if the velt had swallowed them up ; then they suddenly come into sight again, being specially visible to the eye when they show themselves sideways. Seen from front or rear, particularly when at rest, they are all but invisible. 
We are in luck; the rhinoceroses are ambling towards us, and come nearer and nearer, siowly following the line of some hollows in the ground.

Now, borne on strong pinions, and brightly illuminated by the sunbeams, one of the great bustards cuts through the sea of air, and sinks down into some low ground far away below us. This is not an unusual sight in the late hours of the afternoon, and soon after we see not only some more of the same species, but also three other bustards of a smaller and commoner species that is more active in flight. It is the Otis gindiana, which I have got to like so much on account of its charming gambols on the wing, that must be a pleasure to every lover of birds. At this time of day it carries on this strange tumbling in the air, and if the day is hot and dry it makes for the neighbourhood of the water, or in any case for certain hollow places of the velt that provide it with at least a certain amount of soft vegetable food. Another picture! A great flock of spendidly coloured crested cranes wings its strong undulating flight and goes away over the hill: I notice in the air the striking appearance of the snake-vulture and a pair of the nimble-winged Bateleur eagles, the "sky apes" of the Abyssinians. My gaze follows them eagerly into the distance. . In what various ways the bird world displays its mastery of the realms of air! Our attention is riveted now on the quiet glicling flight of the vulture in the highest levels of the air, now on the spectacle of at struggele in the air between some birds of prey and some ravens or bee-eaters that are annoying them. 


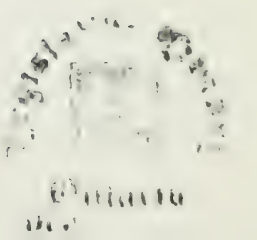




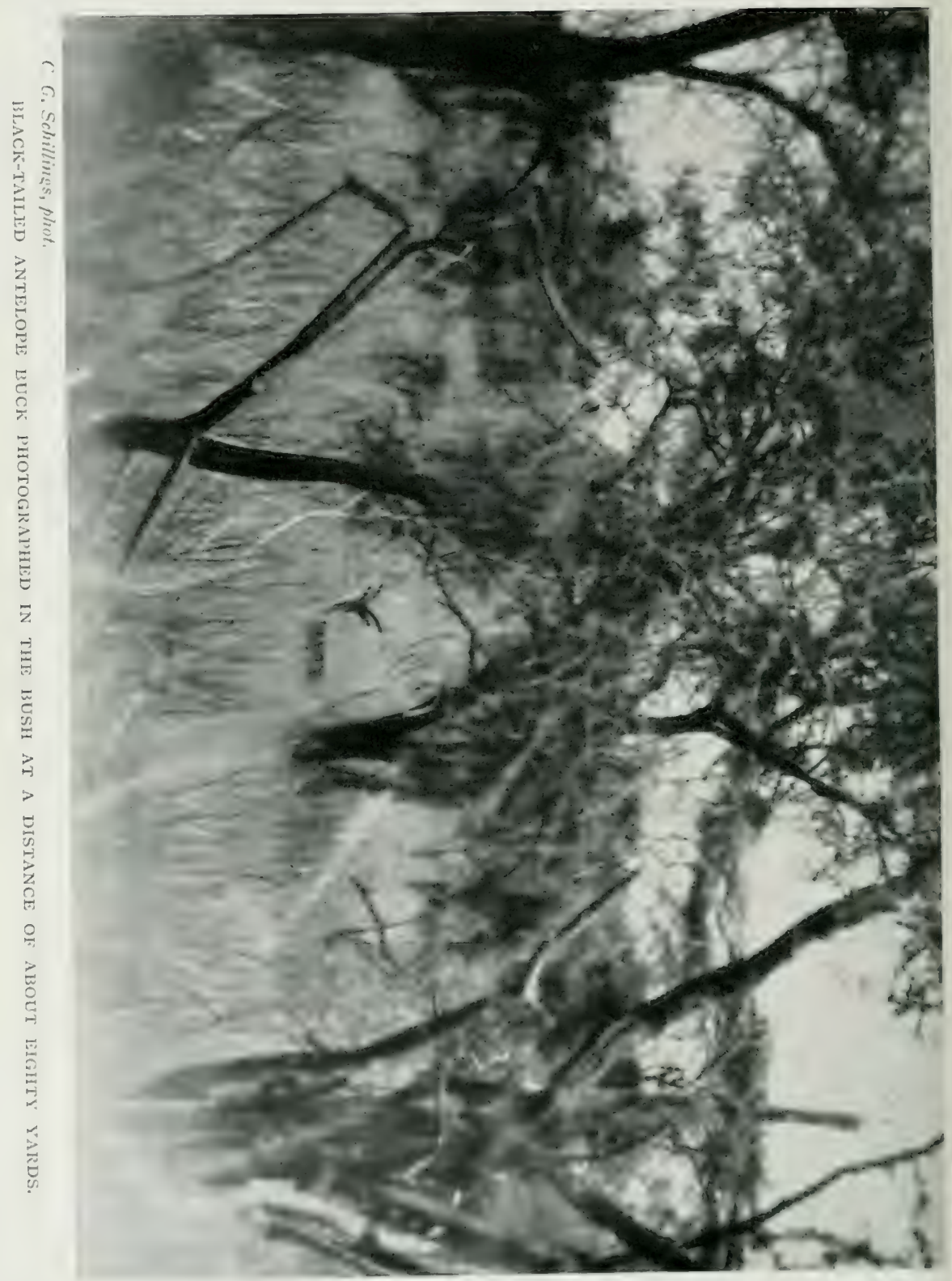




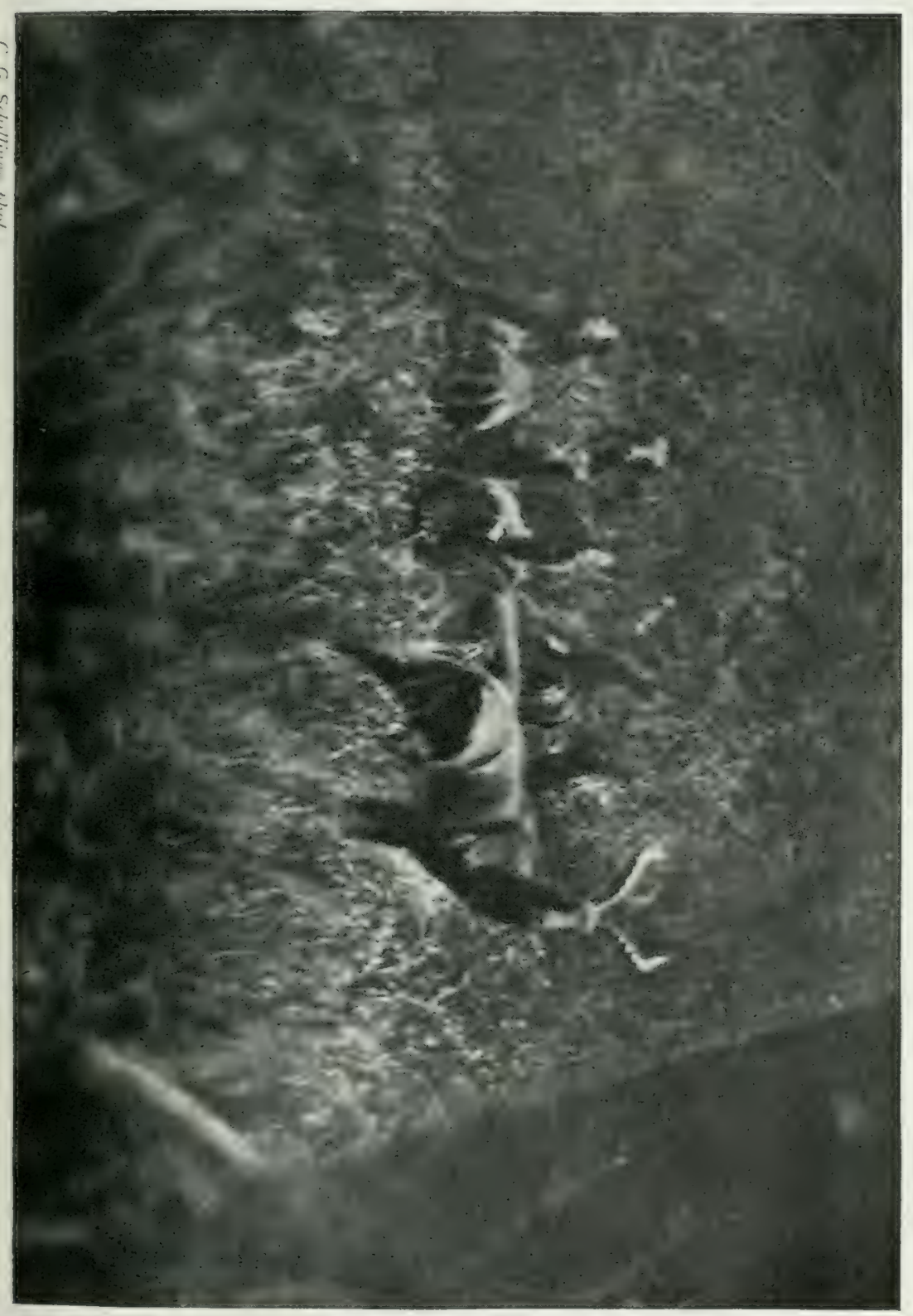



- The Lonely Wonder-world of the Nyíka

Searching the ground as it goes, the augur buzatrd (kulco angur) wings its flight over the stone-strewn slopes of the adjacent hill. Bateleur eagles wheel in graceful circles high in air, let themselves fall down for several yards, and then shoot up again heavenward. For hours at a time they will carry on their strong-winged circling and plunging through the realm of air, apparently without effort or fatigue. Various kinds of kites show themselves in their oscillating flight, that makes them always so clever at escaping the gun; amongst them large numbers of Montagu's harrier (Circus pygargus, L.), which at certain times of the year range restlessly over the velt. Hawks and sparrow-hawks wing their rapid flight in search of prey. In short, every kind and form of bird flight that one can imagine! For instance, the proud majestic flight of the larger species of vultures is essentially distinct from the heavy flight of the small Egyptian vultures (Neophron percnopterns, L.), whose flight the Crown Prince Rudolph of Austria most aptly described, when he remarked that at a distance the bird might easily be mistaken for a stork.

It is indeed a great pleasure to follow with the eye all the wondrously beautiful types of flight that the African birds of prey present to us. The enormous numbers of birds of prey, in a land that is nevertheless so rich in wild life, ought to suggest some salutary reflections to those who, here at home, with such dogged persistence wage war with guns and pole-traps against those creatures, which are so great an ornament to the landscape. For my part, I would on every point support

VOL. I

225
I 5 


\section{In Wildest Africa}

the proposals of experienced men, like Freiherr von Besscrer of Munich and Dr. ron Bocksberger of Marburs, who advocate protection even for our birds of prey, at least within the Government domains. "Let us try," says Von Besserer, "still to preserve them at least within certain limits. Let us grant them some few places of refuge. Let us not arraign them too strictly for every theft, so that future generations may also enjoy the spectacle of their beautiful flight."

And now it seems, as if on some gigantic chess board, move after move is being made on the plain below us. We have hardly remarked the wild species already noted, when we suddenly find ourselves perplexed as to which point we shall first direct our gaze to, which is to attract the special attention of our eyes. To our right, two great herds of zebras come rolling along, and ever as they move are now plainly visible, now almost disappear, as if in regular alternation. To our left, on the crest of a ridge that rises there, suclenly sharply defined silhouettes appear-again it is a herd of gnus, and this time clearly one that numbers at least a hundred and fifty head. While our attention is still attracted by this beautiful spectacle, my trusty comrate Ablatlah sudelenly laty his hand upon my arm and, only with a glance of his eyes, indicates the little valley that lies stretched out below our feet. This time there is good excuse for his caution. For there, looking as if they were cast in bronze, two of the wonderfully batutiul giraffe-satelles stand staring up in astomishment at the place where we are posted. It may well be that these timid children of the wilderness here had never 226 
- The Lonely Wonder-world of the Nyília

yet been disturbed by the strange sight of a human figure. "Nyógga-nyógga!" whispered the lips of my comrade.

It is not often that one has the chance of seeing the nyógga-nyógga at such close quarters, and besides, it is extremely difficult to watch it without being noticed by it. It is so completely lost to sight in it:s surroundings, and is so extremely timid and watchful, that I have very seldom indeed succeeded in observing this splendid animal before it has itself remarked my presence. When I succeeded it was almost invariably towards evening when it had come out to feed. It is worth while to take full advantage of such moments, for the slightest disturbance instantly drives it away. And so it was now. It was not long before the two nyógga-nyógga, with their long necks stretched out, disappeared in the hollows of the broken ground that extended below the place where we stood. After this I caught sight of them a few times standing amongst the clumps of acacias, timicl, surprised, and watchful; then the gazelles betook themselves to the protection of the wide velt, looking like mere points in the distance.

To me it seems as if the sonorous name that the Swahili language gives them, and also the softer name that sounds so sweetly in the mouth of a Masai,_- "Nanyād,"--best and most fitly express their beauty, strangeness, and grace.

Again we turn our attention to all that is going on below us. This time it is the rhinoceroses, which have approached to within a few hundred yards of my post, that most engage our attention. We observe how they nibble here and there at the boughs of the Saliadora persica and 
other shrubs, and then agrain rub their rough hide or their horns against the strong trunk of a tree or on a block of stone. They have all this time been coming gradually nearer to the herd of gnus that we first noticed, and now at last they stand quietly on the level ground, only a hundred paces away from the old gnu-bulls which are acting as sentinels.

And now it is I myself who am the first to make out with the glass a third rhinoceros. "Wapi, bwana?" my companion eagerly asks me, and as I point out to him the place on the velt where I have picked the animal out, he approvingly confirms my observation with the remark: "Ndio, bwana, pharu mkubwa sana" ("Yes, master, a very big rhinoceros!")

After some time we see that it is an old and unusually large bull; he, too, has gradually taken the same line as his two colleagues. Our observation proves to be correct, and we also remark before long that the first pair of rhinoceroses we had noticed is made up of an old cow and her nearly grown up young one.

More herds of zebras and gnus, and small troops of Grant's gazelles and of impallah-antelopes have come into sight, and now they are joined by a whole crowd of hartebeests, which so far have kept themselves hidden in a side valley of the velt full of thick tall grass.

And now the moving mass of animal life is ever more abundant, more varied. I notice in the valley at the foot of my hill a string of guinea-fowl; how they hurry and scurry about, flutter up with sounding strokes of their wings, and then soon drop down again! And now my 



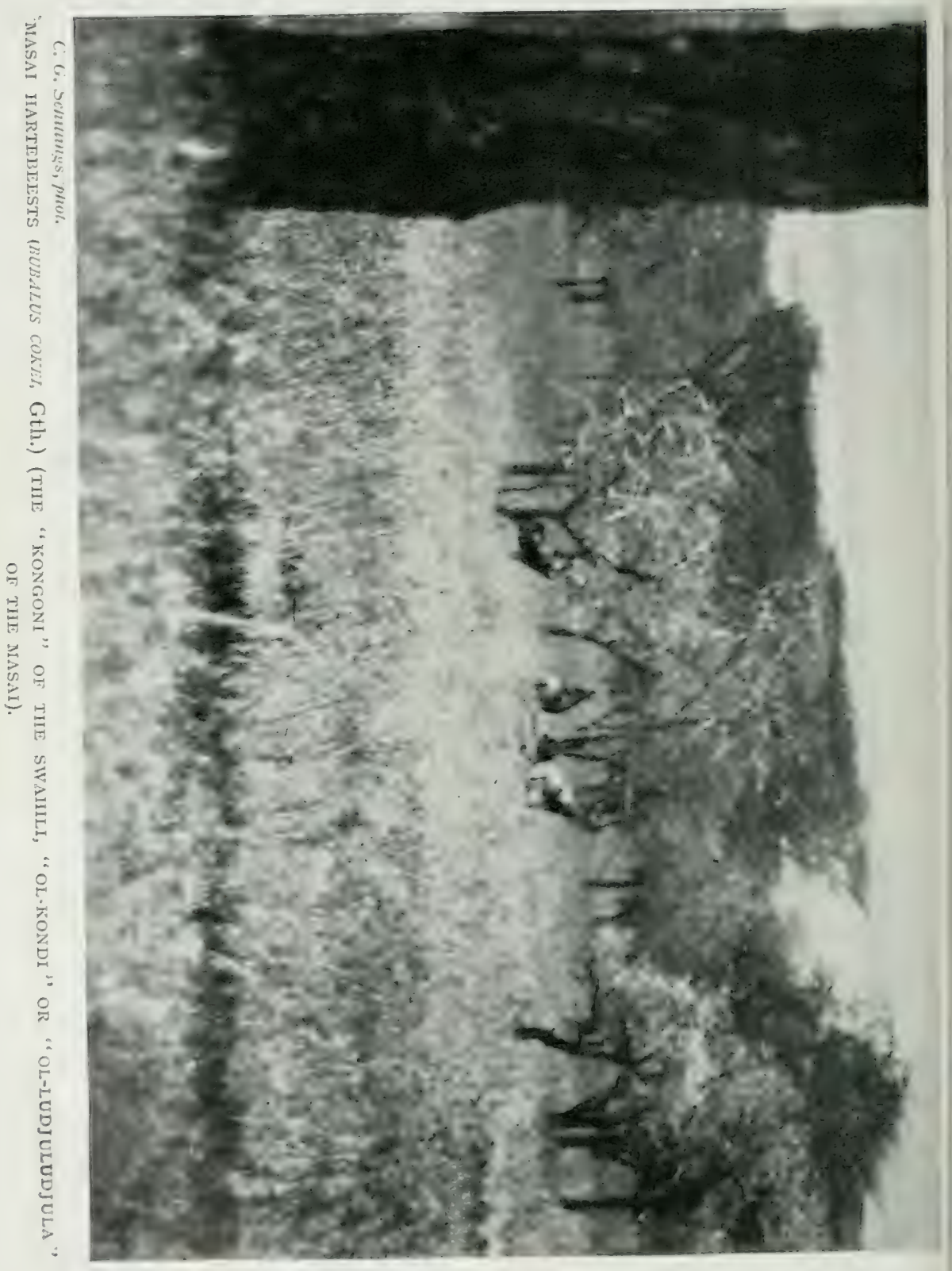




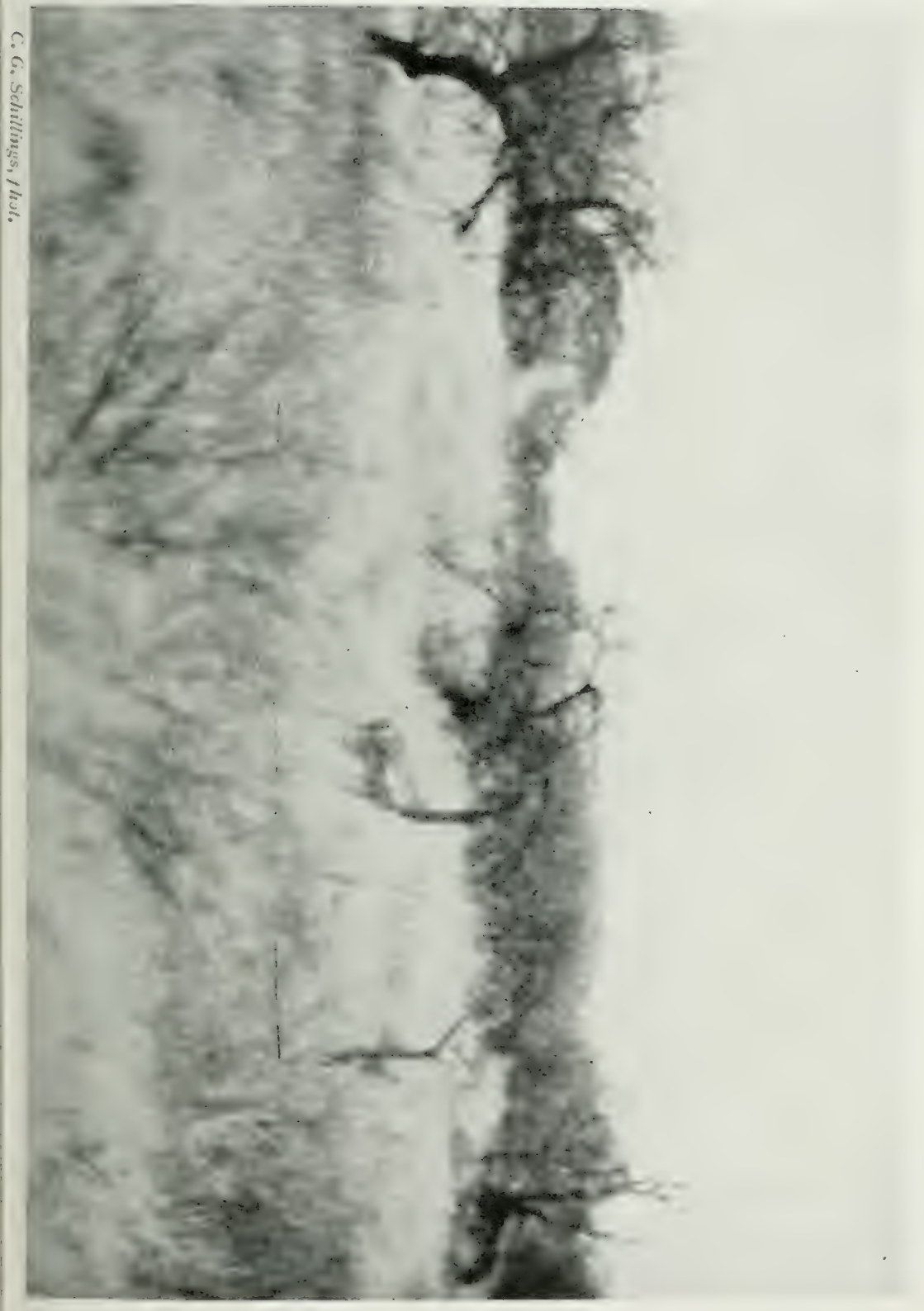



attention is attracted by a pair of Bateleur eagles, that wheel in the air, and enjoy themselves for an hour at a time playing on the wing. They probably have male their eyrie not far from this spot.

For minutes at a time the cry of the francolin rings out clearly round about my post; then again it is silent. My eyes can indeed see animals of many kinds, and my sight ranges with restless efforts over the far distance; but so far I have looked in vain for a form that is frequent and familiar enough in this wilderness-the towering figure of the "Twigga."

Where can the giraffes be hiding to-day? Why have they not come out to the still freshly green acacias in the far-stretching hollow to my left, where I have already marked their presence for whole days at a time?

And yet they are there, only I had failed to distinguish them. At last I can make out their strange forms, as they graze there among the acacias, and they stand out sharply under the oblique rays of the sun.

What poetry there is in the movements of all the various organisms that our eyes behold! Every variety of gait, from the heavy, swinging, and nevertheless rapid march of the pachyderms to the graceful speed of a pretty gazelle, speaks in a language of its own to him who has become familiar with the peculiar movements of this animal world. Just as at the outset the strange appearance of an animal one sees for the first time makes a surprisingly strong impression on one, so too does the great difference in the gait of the various species. But they were all soon familiar to me. So now at the sight of 


\section{In Wildest Africa}

the giraffes I feel a pleasure and delight in their quaint coming and going, their heads appearing and disappearing. there below me in the midst of the green bowers of mimosa leaves, high over which my view ranges. What laws must be at work here too, by whose operation I am compelled to feel all this to be so beautiful, so harmonious. so splendid! I grasp the meaning of the words : "Therefore I believe that life will first open its eyes in that world of which Goethe said: "There is still the life of life, and this is only form." "1

What a splendid sight there is from my lofty look-out! the whole of this mighty spectacle displays itself almost without a sound that I can hear. Only a few voices of bircls, but no cry of any other animal reaches my ears. But as the breeze rises more and more towards evening, there begins in my immediate neighbourhood a strange and beautiful concert, that is already familiar to me. And now, as the wind blows more and more strongly through the perforated gall-nuts that hang on every tree above us, there resounds through the desert silence a strange melody, a strange language of musical notes that only the sound of the Eolian harp can to some degree represent.

These nut-galls on the acacias are bored quite through, and in many cases become the dwelling-places of small ants. If one disturbs them by tapping on the outside of their strange habitation, ${ }^{2}$ they come swarming out to fight

1 Houston Stuart Chamberlain, Immanuel Liznt.

I According to the latest observations of Professor Ingwe Sjöstedt these nut-galls are inhabited by three different species of ants. 


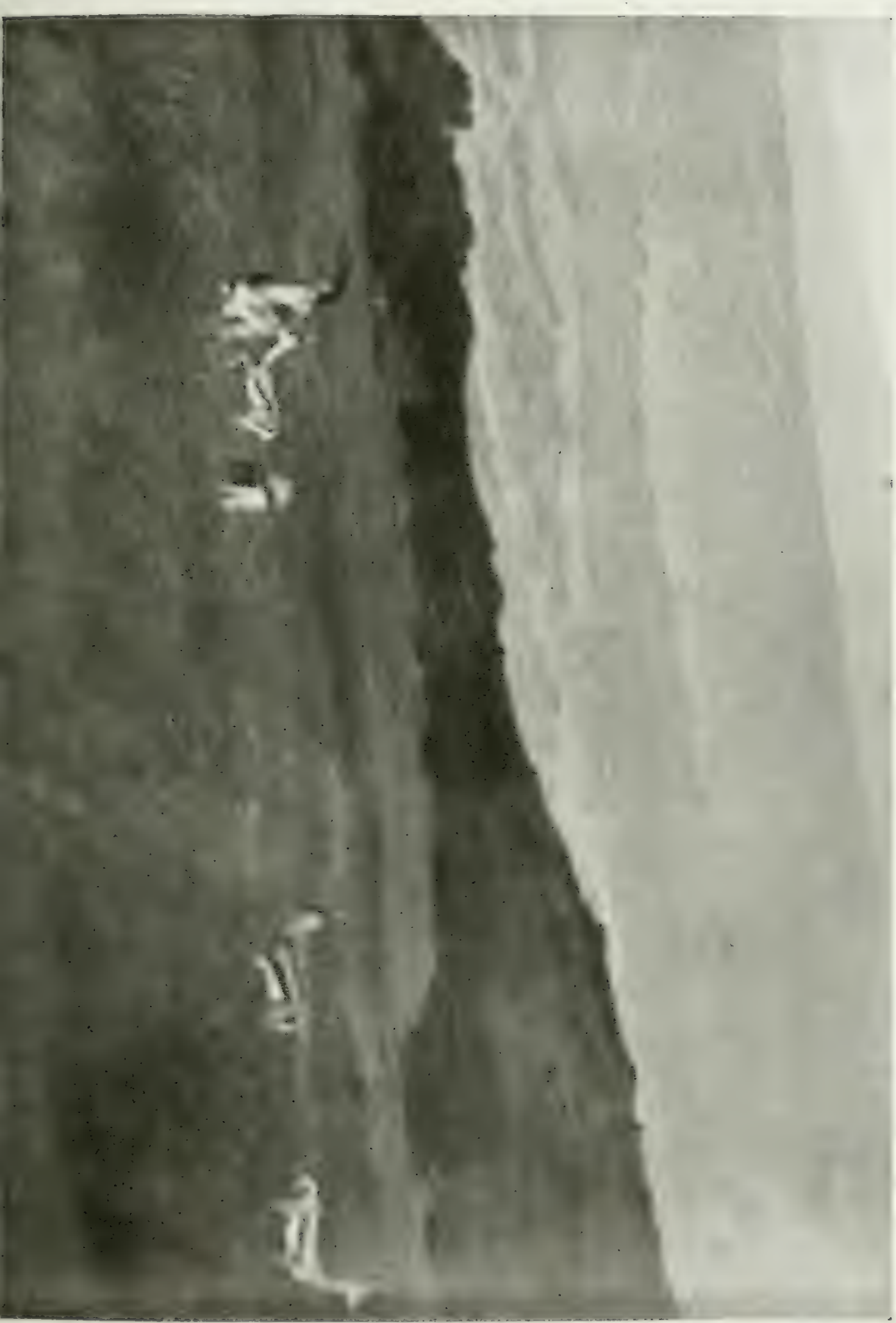

$$
\text { कै }
$$

(191161116

1.. 

- The Lonely Wonder-world of the Nyíka

with the disturber of their peace! It is not so often that their strange ways and doings concern a human being, but it comes to pass to-day. The watchful observer takes delight not only in the sound of these strange musical instruments, but also in the thought that they give shelter to a little world of their own, a peculiarly organised little state made up of living beings, just as the wide endless wilderness below them is a state with the various larger wild animals for its inhabitants.

My diary records yet another kind of natural observatory, a giant tree uprooted on a wooded river-bank. Here, as it were, in the gallery of the wood, the huge trunk felled by the storm-wind offered me an inviting seat among its branches, and thence I enjoyed many a sight of the animal world around.

There I had a view of the river close at hand, and farther away many clearings of the wood, which at this time of the year showed a rich display of animal life. The ripening forest fruits had attracted into this neighbourhood large packs of baboons. It was good to watch their busy activity as I looked down from my observatory, where I sat hidden by a thick growth of creeper. Great herds of antelopes, and especially waterbuck and Grant's gazelles, are regularly to be found in these wide clearings of the woods. I remember some hours of the afternoon when the life of the forest displayed itself here in a way that suggested Paradise: I saw at the same time a large drove of the graceful, wonderful pallahs, and, grazing in their immediate neighbourhood, some twenty Grant's gazelle bucks which had joined together to form a great 
herd. The antelopes had scattered themselves over part of the clearing, feeding on the fresh growing grass there, but all the while keeping themselves somewhat apart from the herd of gazelles. But they had gradually drawn near to a party of waterbuck which were standing under an old shady tree, and now I had an opportunity of watching for a long time these three varieties of antelope, all so beautiful, yet so different. To my surprise, after some time they were joined by nine stately eland-antelopes. whose white side-stripes made them wonderfully prominent among the uniformly coloured coats of the waterbuck. Amongst these animals some three hundred baboons were moving about with a certain careless self-possession. They were all big ones, keenly devoted to the hunt for insects, pulling up grass and turning over stones. Some of the older individuals meanwhile scrambled up tree trunks for a few feet, and thence kept a careful look-out for the approach of any possible enemy.

I kept as still as a mouse, knowing well that the slightest movement would betray my presence to the timid, keen-sighted monkeys.

Now a numerous herd of zebras moved through the wood and across the clearing at a slow, careless pace. As they moved there was a bright shimmering of the variegated stripes of the beautiful "tiger-horses," and again they would often be blurred into one uniform grey. They mingled with the waterbuck, which took very little notice of them, and evidently had known the zebras for a long time. It was wonderful to see the proud waterbuck, with their horns, which are at once weapon and 236 

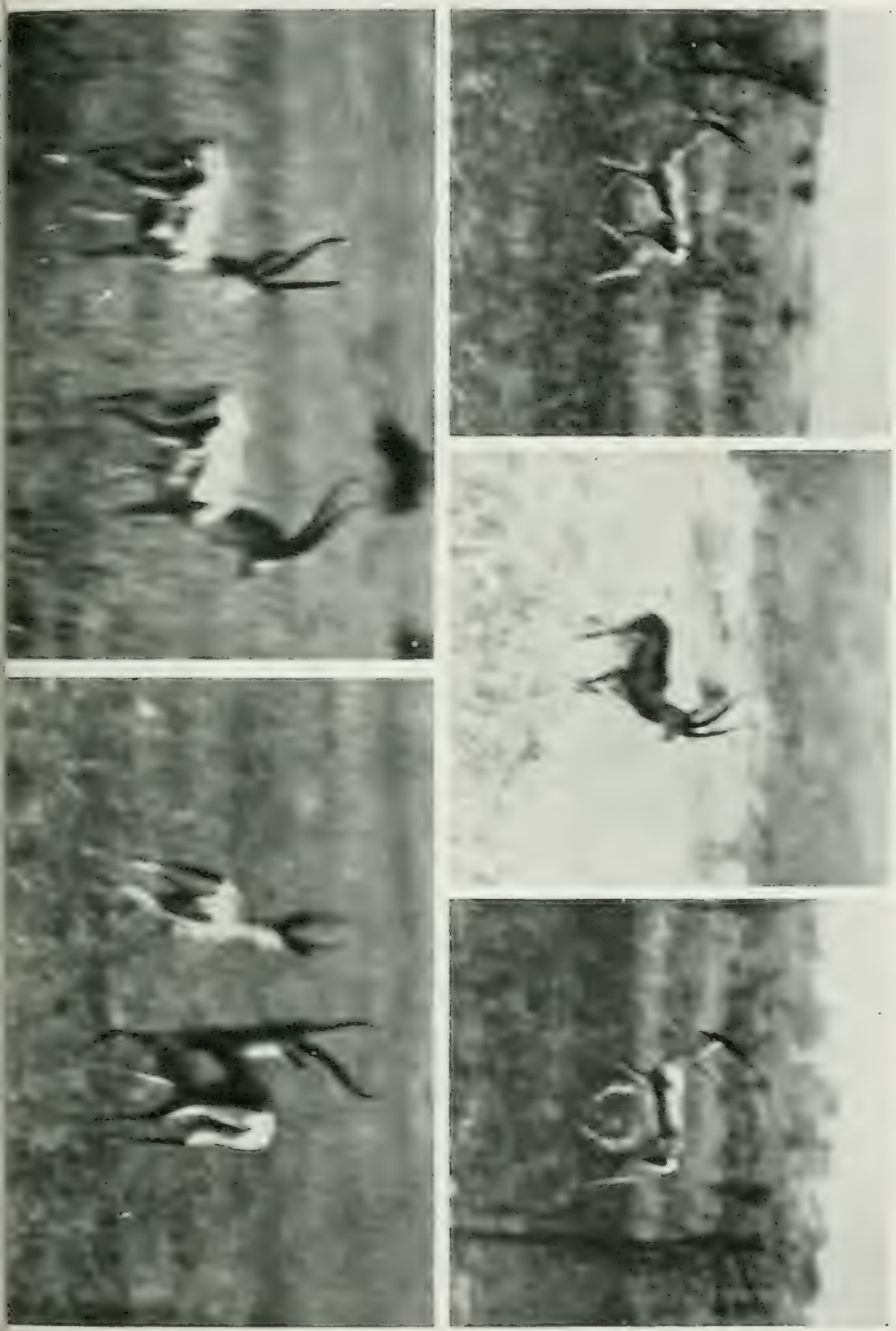

- The Lonely Wonder-world of the Nyíka

ornament, and the stallion leaders of the zebra herd all continually on the alert watching against their enemies.

There is a scuttling over the ground, for the little mungoose family, that live over there among the anthills, are making a sally from their fortress. Snake-like in their swift movements, the graceful little animals seem to glide along. Yonder two snake-vultures are looking for reptiles. Numbers of other vultures and marabous have flown down to the margin of the shallow water to bathe and drink.

Into the midst of all this gathering of animals there now come three ostriches, making for the fresh green growth along the marshy edge of the river-bank, and a number of francolins and guinea-fowl that gradually come crowding out of the undergrowth into the clearing to feed there. On the sandbank on which I look down as it extends far along the course of the river, there are some thirty huge crocodiles sunning themselves. I can see several smaller specimens of these mail-clad lizards on a flat part of the river margin not far from the sandbank.

Yesterday, too, six giant hippopotami paid a visit to this sandbank on the primeval river, and left tracks that my eye can plainly see in the glowing sunshine; to-day, however, I have waited in vain for them to show themselves. But suddenly from the reed-beds on the opposite bank of the stream the mighty voice of an old bull comes booming across to me.

Over this most peaceful picture of animal life the tropical sun blazes, casting deep shadows. At this hour 
of the day even the voices of the birds are generally silent. Only the melodious piping of the organ-shrike sounds somewhere near me, and often, too, the cries of one or other of the baboons which is being corrected with bangs and cuffs by an older member of the pack.

All the various kinds of animals assembled here get on quite peacefully together. They often almost touch each other, without taking the slightest notice of one another. Even the antelope bucks, adorned with dangerously pointed horns, make not the slightest use of their sharp weapons against the other species. All the time that I was looking down from my lofty seat I saw nothing but peace and good-fellowship. And yet how quickly a tragedy might interrupt this stillness and peace! The tracks of lions and leopards down there, the crocodiles on the sandbank, and the vultures hovering in the air told me that.

Often in this, and in other places, I have gained an insight into the life and ways of the animal world, and I have thus passed many enjoyable hours. Now one, now another species presented itself to my observation, but it was seldom that I saw such a large number of different species at the same time. But in all cases I have found that man is a disturbing element in the midst of such pictures of the animal Paradise. Even where I could feel sure that the appearance of a white man, a European, was quite unknown to the animals of the district, even then the very moment I showed myself the immediate result was a panic-stricken flight.

I have still clearly before my eyes the picture that 2.40 


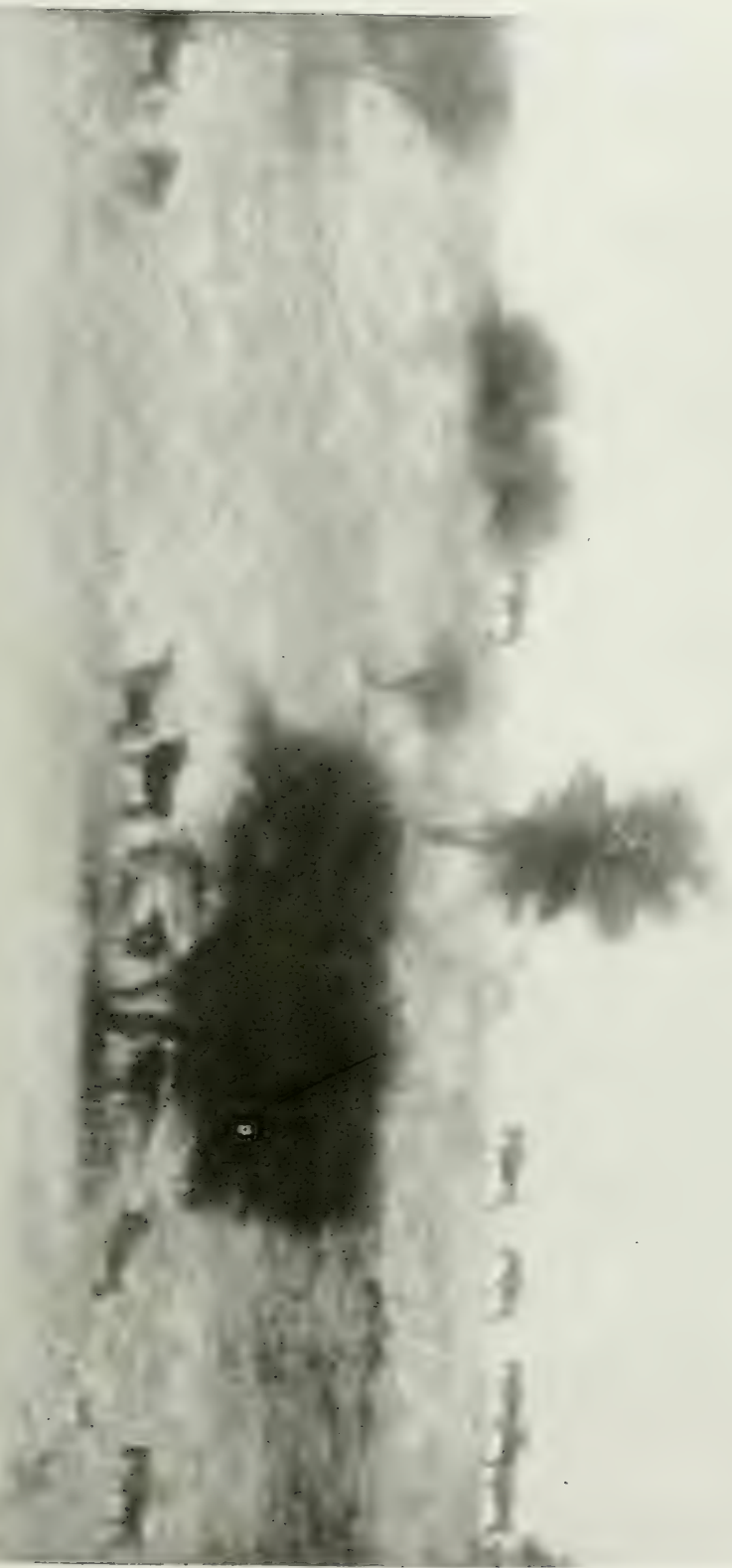



- The Lonely Wonder-world of the Nyíka

presented itself to me as I emerged from the overgrowth of creepers on the boughs of that uprooted tree. First a shrill cry from the monkeys. In a trice the little young ones were clinging to their mothers, and with long bounds the whole crowd of them galloped away over the level ground, hidden in a cloud of dust, and disappeared on the far side of the clearing. There a good many of them halted to look back. Of all the animals known to me only the baboons and the spotted hyenas take to flight in this way. The spectacle has such a surprisingly strange and unaccustomed, almost uncanny effect, that it always recurs to me when I think of these animals.

The antelopes follow the example of the fugitive baboons, after first rushing hither and thither, right and left, leaping wildly into the air. At this moment the impallah-antelopes, especially, make a splendid picture. Bounding along as if on springs of steel, they shoot up several yards high into the air. Wherever the eye turns it sees the graceful forms of these beautiful animals in all possible positions, making long bounds, some four feet high off the ground, and in every other attitude that one can imagine. But the end of all these splendid pictures, each seen for a moment, is a general stampede. Whirling clouds of dust in the far distance tell for some time longer which way the fugitives have taken.

But it is not every day that such varied pictures, so richly stored with the life of the primitive animal world of the tropics, present themselves to the traveller. And VOL. I $24 \cdot 1$ 
it needs, too, a trained eye to enjoy all the separate impressions in their combined effect, as making up one masterpiece of Nature. But often, too, an almost too great wealth of beauty gathered together in a small space presents itself to our eyes. Thus, more especially, I keep a memory of these small idyllic lakes of the wilderness, that are hidden away here and there in the Nyika district, and give a home to a wealth of animal life that often seems almost too abundant. We sometimes find one of the most interesting species of the larger mammalia, the hippopotamus, living here in somewhat narrow quarters, but thus more easily accessible to observation than in the great lake basins, where it lives in hundreds or thousands, but where also it can much more easily get away from the sight of the observer. It is true that one can see numerous heads emerging from the water in the distance, one can mark the thin spray of water blown from their nostrils, forming numbers of little fountain jets that glitter in the sun. But the peculiar life and activity of these griants of the animal world goes on chictly at night, invisible to our eyes. In the smaller lakes it is all different.

I remember with pleasure a certain gathering of hippopotami in one of the lakes that lie hidden away between Kilimanjaro and Mount Meru, and which were discovered some years ago by Captain Merker. When I saw them there were still living in them some hundreds of hippopotami, and it was easy to watch their doings in the water. Gathered in herds they played about in the water under the bright sunlight, showing little sign 



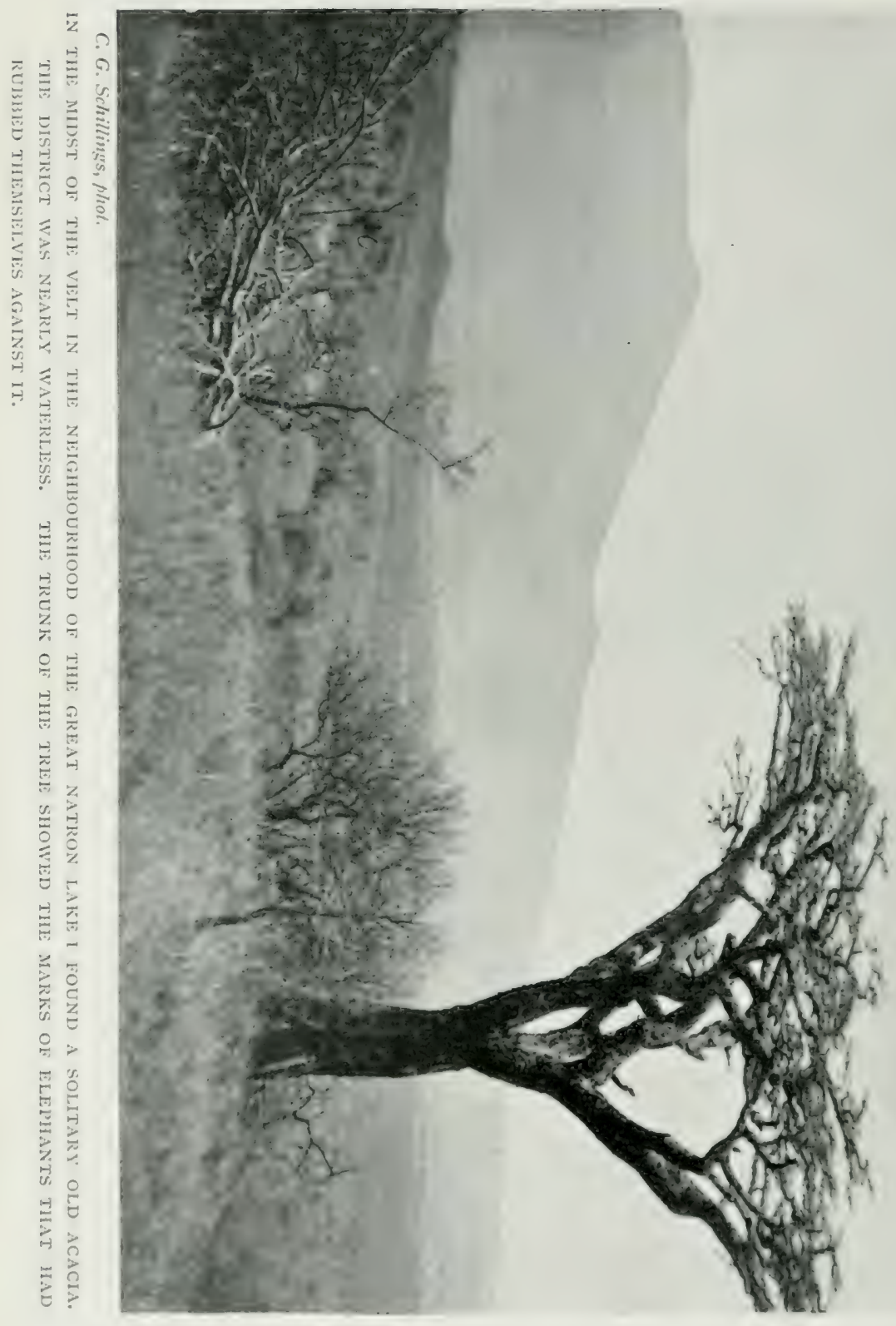




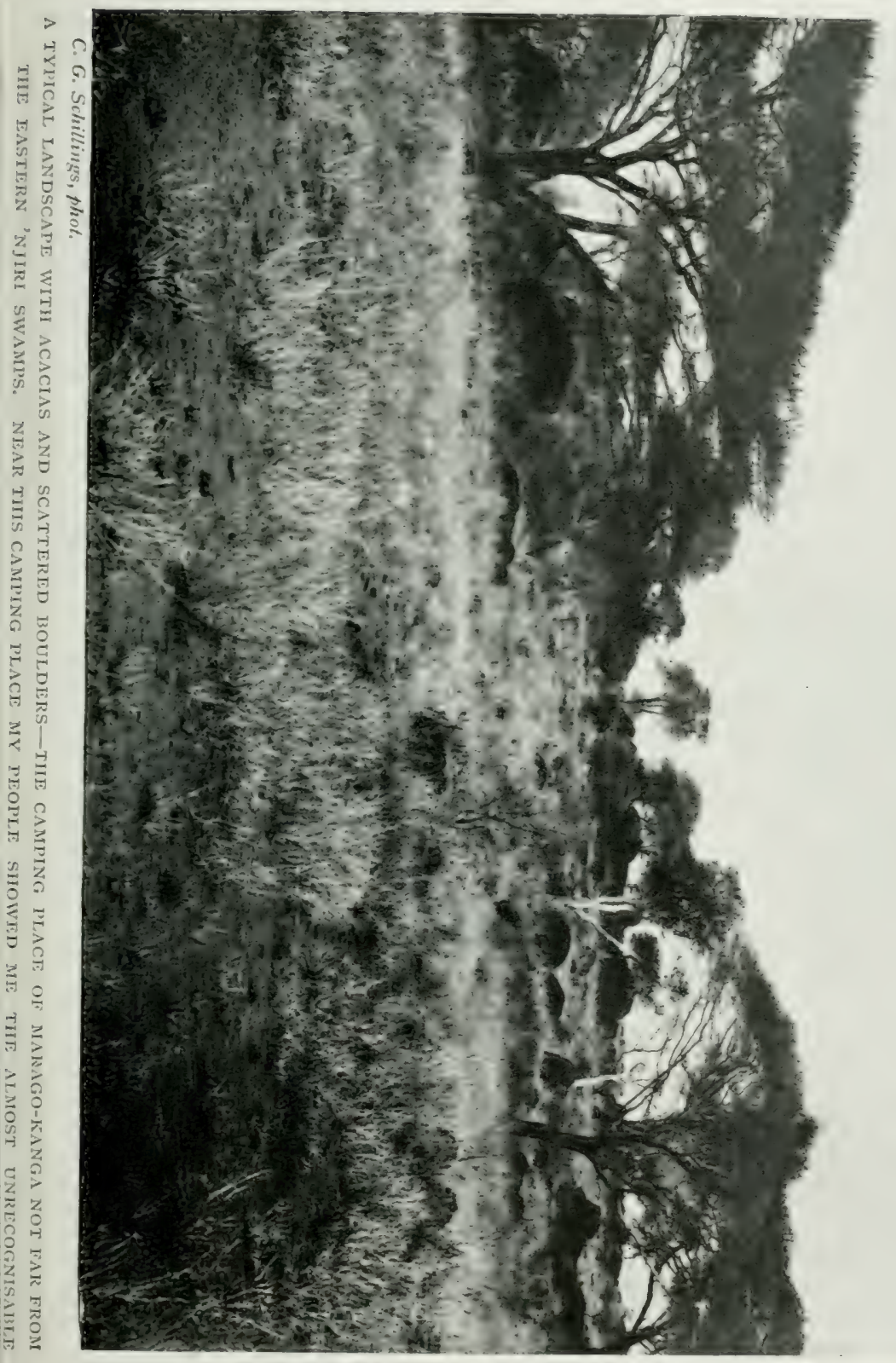



- The Lonely Wonder-world of the Nyika

of timidity. Especially the young ones, that were still going about with their mothers, had so little fear that I sometimes saw them rising almost completely out of the water. They were also sometimes to be seen resting in the sunshine on the sandbanks by the lake margin. Some of these lakes were of such small extent that the animals had to come up to breathe at a distance of at most only some twenty yards from the observer. But all the same they were generally inhabited by quite a number of hippopotami. It was then a great pleasure to watch these beasts for hours at a time, from the lofty look-out place provided by the surrounding heights that rose steeply from the edge of the lake. They kept up good fellowship with the crowds of water and marsh fowl that give life to these lakes. All these animals displayed themselves to the spectator at as close quarters and as plainly as in a zoological garden. The rosy red pelicans fishing in flocks of hundreds at a time presented the most charming contrast to the uncouth quadrupeds. Even now in fancy these lakes come before my sight, lakes that lie far from all human ways and doings in a silent solitude. Dark clouds float over it. The proximity of the massive and dark Mount Meru often causes a cloudy veil to hang orer that volcanic plateau with its crater lakes. Again I climb the steep cliffs that ring them round, and again my gaze sweeps over the level surface of the water. But though there has been no decrease in the numbers of the waterfowl that enliven the lakes, the hippopotami have, alas! disappeared. I found on the occasion of my last journey a small number still there, but I hear from Professor 


\section{In Vildest Africa}

Siojstedt, ${ }^{1}$ the Swedish naturalist, who lately risited these lakes, that the hippopotami, who had made the lakes their home since dim far-off times, have almost disappeared. The Boers" have killed everything. I came upon one here some years ago who was killing a lot of the hippopotami; others have followed up the work of this forerunner with more serious results. Attempts to make settlers at home in primitive regions are almost always inconsistent with a protection of the primitive animal world, even though these animals inhabit lonely upland lakes, hidden away in the wilderness, far from human settlements.

Thus in memory picture follows picture.

Besides the harmonies of the wilderness, the impressions of the eye are always those that come back alluringly in my recollections. However truly the artist may be able to reproduce all these various impressions, there is one kind that will always be missing from his pictures, namely, all the fleeting movement. To take

${ }^{1}$ Cf. also Prof. Yngwe Sjöstedt on the destruction of wild animals by the Boers in the Kilimanjaro district, in the Täglichen Rundschan, Berlin, 1906. Professor Sjöstedt travelled through these districts for the purpose of making a collection of their fauna for the Copenhagen MIuseum, and visited the Merker Lakes with a view to securing a hippopotamus.

"The destruction of wild animals by the Boers in the Kilimanjaro district was in every way opposed by the central and local authorities, but failing the possibility of strict control it does not seem to have been possible to make the regulations effective. Prof. Sjöstedt found the Boers in no way settled down, but roving about the country in pursuit of the wild animals. 


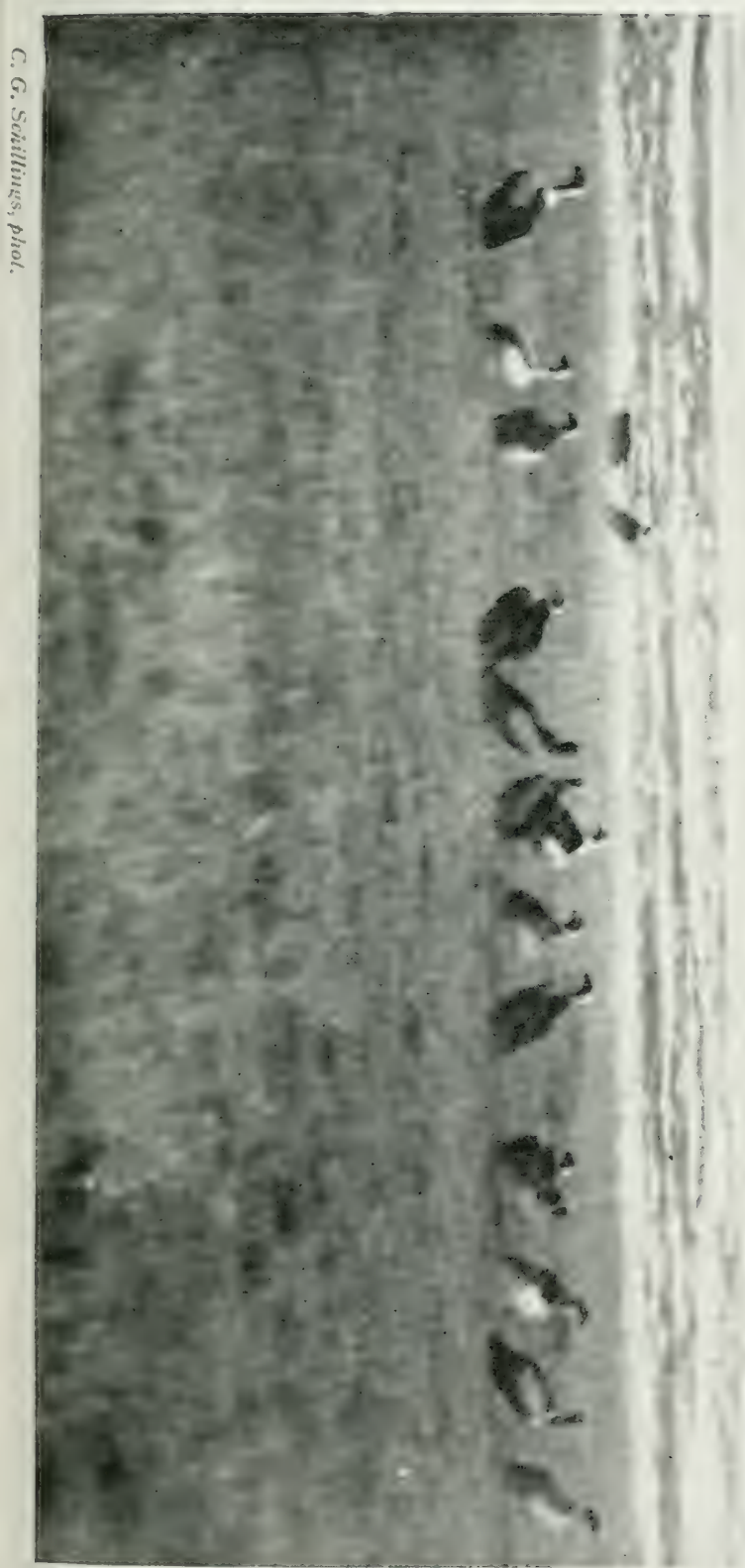



as an instance only one out of an abundance of forms, who can reproduce in pictures the endless variety of birds, the world of winged life! Every day added to my knowledge of these multitudinous flecks, through the increase day by day of my bird collection, which I obtained at the cost of much labour, and which has been the means of giving to science many hitherto unknown species. As I added each new bird to it, I added also to my knowledge of these beautiful creatures, as yet so little known, and slowly, very slowly I became familiar with them. What splendour of forms and colours! In what enormous flocks does the feathered race inhabit the wilderness and the primeval forest! The Biblical account of the flocks of quails in the desert sounds to us like a legend, and yet it is no legend. At times when we too were marching across the same kind of ground, there flew past us with a whirr of many wings huge flocks of quails, that sought and found their safety in flight. At times I have also seen similar flocks of snipe. How long has it been since both these kinds of birds appeared in such flocks in our country at home?

The endless variety of form and colour, the movements of the animals which the eye perceives under the everchanging tropical light, that shows everything brilliantly and sharply defined, all this taken together makes up memory-pictures of a charm that nothing can surpass. But he only can picture them to himself who has gone forth and made them his own.

The huge sea-turtle comes creeping along, emerges from the waters of the Indian Ocean, and makes for the 


\section{In Wildest Africa}

sandhills to lay its eggs there. Its giant track on the sand leads me to its nest. To my astonished eyes this peculiar track looks as if a ploughshare had torn through the ground.

The Indian Ocean, which is the home of this huge sea-turtle, shelters also in quiet bays the strange Dugong or sea-cow, and great is the surprise of even the natives

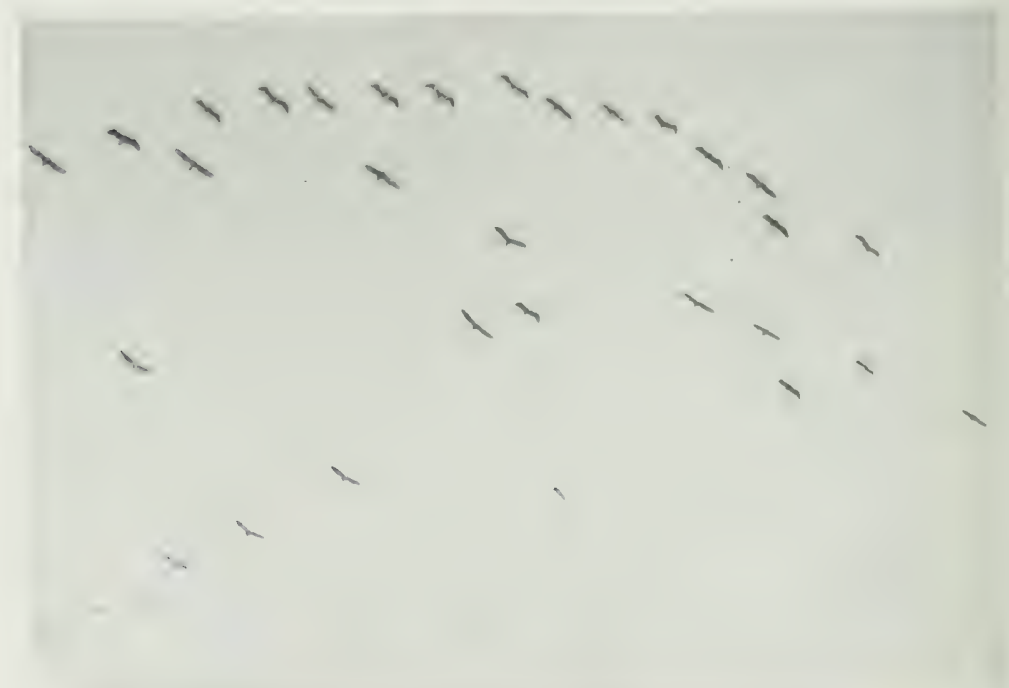

FORMATION OF A FJOCK OF FLAMINGOES IN FLIGHT.

themselves when from time to time they capture in their nets this remarkable creature, which is becoming rarer every year.

In the lagoons one sees emerge from the surface the head of a great giant snake, a good five yards long, the African python; others I have come upon suddenly on the open velt. There are continually thrilling 


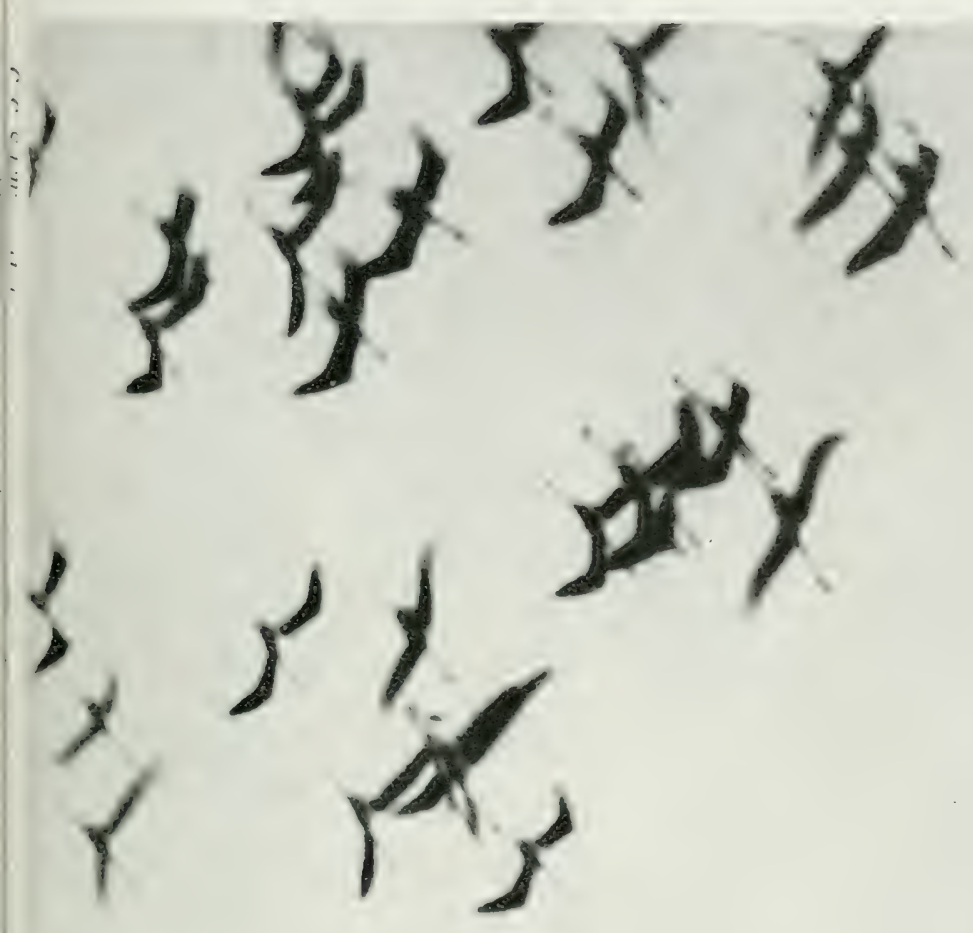

)
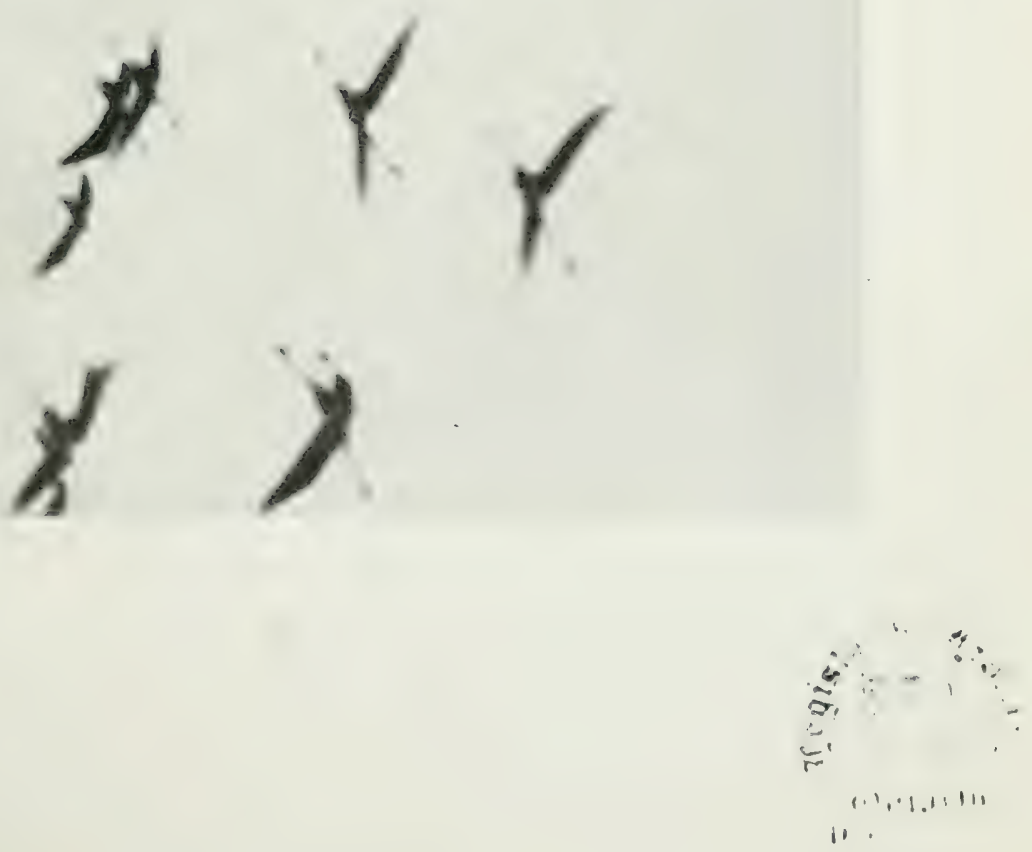



\section{- The Lonely Wonder-world of the Nyíka}

moments! It may be that memory conjures up for us the delightful fairy-like image of a rare dwarf antelope seen perhaps once only in the shades of the forest, a diwarf antelope that, with strange large eyes and ears alert, watches one's approach, and then like a flash of lightning disappears in the thickets; it may be that in memory one sees the reddish brown, mud-smeared body of a giant elephant emerge from the midst of some densely tangled primeval forest; it may be that a tree suddenly bursting into bloom yields me a wonderfully beautiful new kind of bird, which I grasp in my hand, delighted with its robe of feathers; it may be that suddenly the massive giant form of a rhinoceros appears before me in the tall grass, unexpected, menacing, standing as if chiselled out of stone; it may be that my free gaze ranges without limit over the wide prospect, and sees in primitive abundance the strange life of the tropics; in every case the impressions received scem to the beholder fascinating beyond description.

Monotonous as the surroundings of the landscape may appear to the newcomer, poor and barren though the velt may seem to be for weeks at a time, yet, enlivened and permeated by the mighty flood of all this strange animal life, it has a beauty and a charm whose influence no one can escape who makes his way into the midst of it with open heart and eyes.

He who looks around him with clear-sighted vision, and tries to see more than others, has revealed to him the beauties of Nature in the greatest and most wonderful way, and is drawn in the highest sense of the word to admiration of them. Here is verified, as Sir Harry 
Johnston says in his preface to my first book, "the old nursery story of eyes and no eyes."

It is thus that I lie for long hours in the wilderness, and observe, admire and enjoy. What a wealth of impressions is brought before the eyes among these ever-changing, at first strange but gradually familiar sights. in the midst of the foreign-looking landscape, bathed in a light that has a marvellous influence, and in its full power is almost blinding.

Now the dwarfs, and again the giants of the animal world rivet our attention. But it is especially the frimeial. abundance, the great profusion of large and small wild life, that gives an impression that is now delightful, now overwhelming. One must have seen, with the eye of the hunter, gigantic old bull-elephants in the primeval forest, great herds of rhinoceroses and giraffes in one single day, thousands of zebras and antelopes gathereal together-one must have felt all this profuse wealth of life, to be able to understand its full beauty and grandeur.

Yet there are days when one looks around in vain for all this life and activity, when, on account of the weather, or some other reason, the animals do not show themselves so freely. One must also take due account of the extensive periodical migrations of the African fauna. Many an erroncous judgment as to the alleged scarcity of wild life, in districts in which other hunters pursucd the chase at an carlior date with success, is to be thus explained.

But, on the other hand, there are also days when such an abundance of animal forms presents itself to 256 
TUL. I 



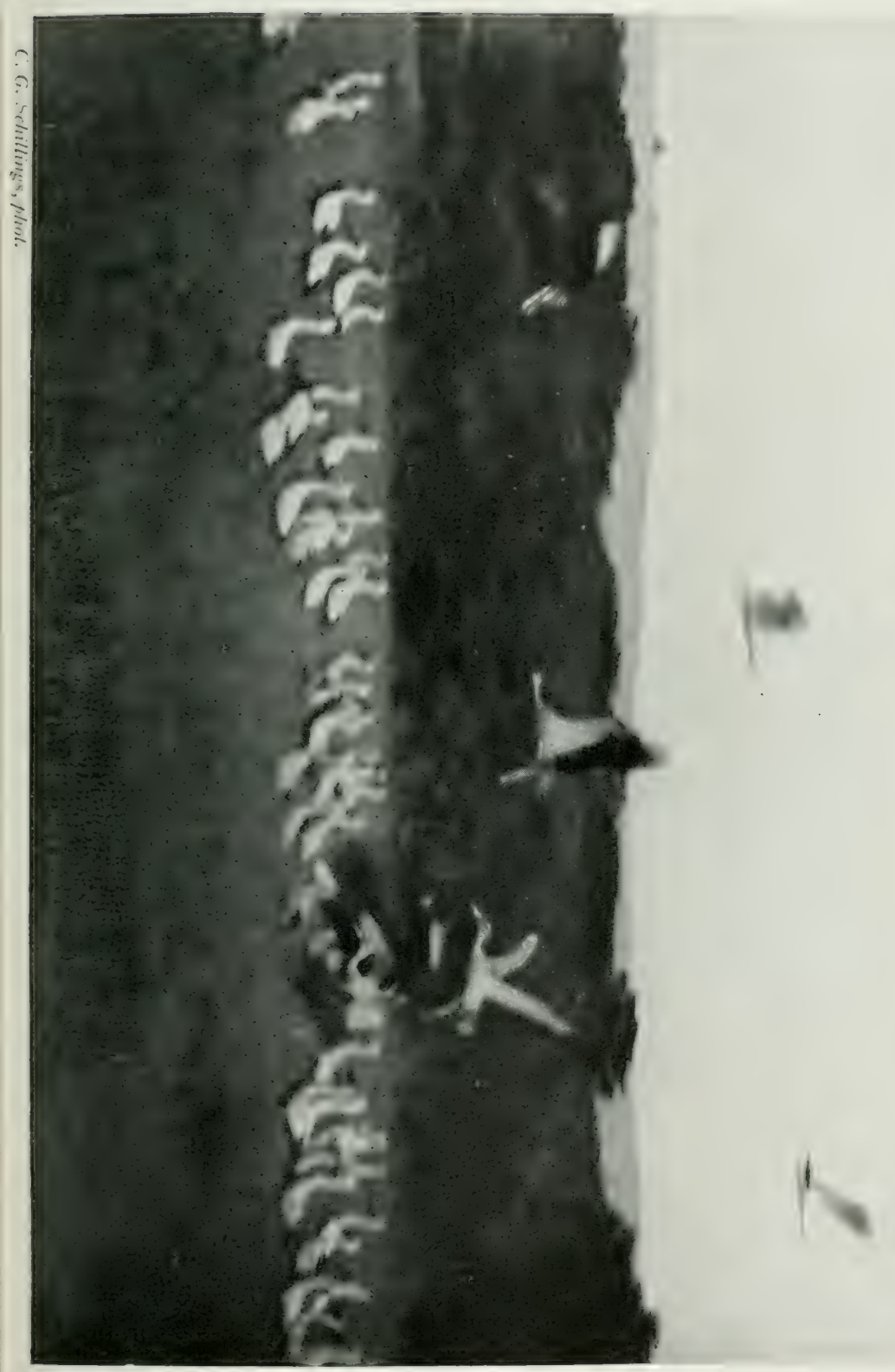



- The Lonely Wonder-rorld of the Nyíka

our eyes, that the most lively imagination can form no idea of all this profusion. On such days, I have often wished that one could have a gigantic photographic apparatus, an instrument that would be capable of making a record of all I saw. But on such days, also, I have more than once made a mental apology to explorers whose lives have long closed in death. When, for instance,

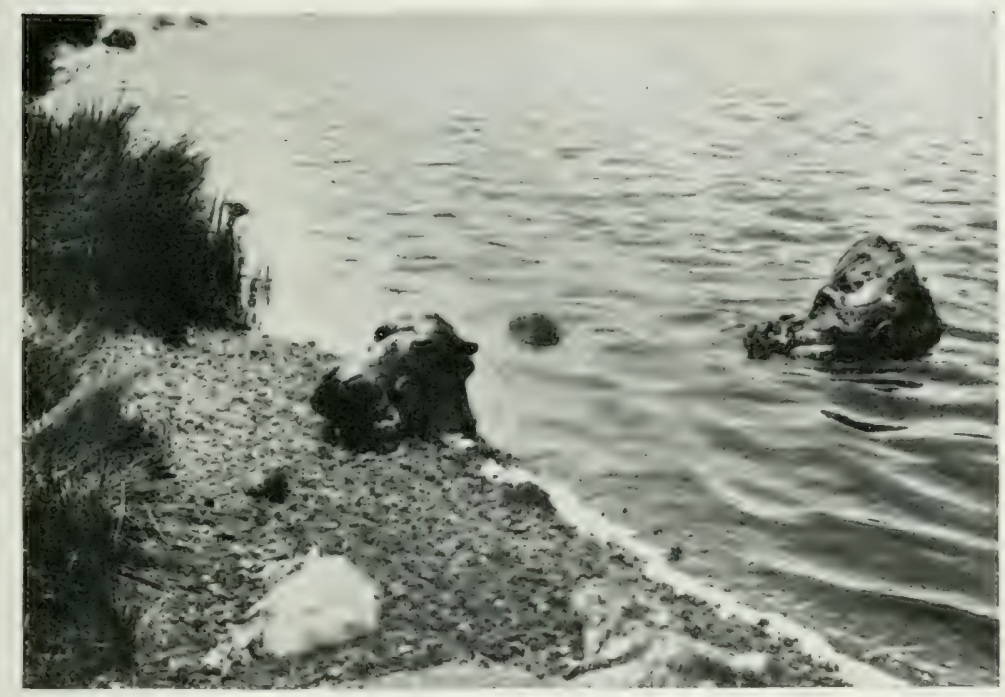

REMAIS OF RHIXOCEROSES KILLED IFY THE LUERS ON THE SHURE OF ONE OF THE, MERKER LAKES.

in former years I had looked over the sketches of the late Cornwallis Harris, sketches showing the life of the South African fauna as he saw it about the year ${ }_{1} S_{37}$, I more than once had my doubts about the correctness of his representations of it. As the result of what I myself have seen, I have quite given up such doubts.

The original sketches left to us by Cornwallis Harris 26 I 


\section{In Wildest Africa}

(which I must say do not always rise to a high level from the artistic point of view ${ }^{1}$ ) are coloured sketches accompanied by descriptions, and show us such multitudes of wild animals that they seem to border on the fabulous. For we see in them elephants, rhinoceroses, giraffes, buffaloes, zebras and antelopes, all gathered together in crowds, and thus one inclines involuntarily to the opinion that all these have been brought together in one picture merely to give illustrations of the various species. But my own observations have shown me that our artist is perfectly correct. One sees how necessary it is to make documentary records of such observations. The men of a later time, as I plainly realise, may be able to place before themselves a picture of all this primitive abundance of animal life only with the greatest trouble and by means of earnest study of every authority bearing on the matter.

Enormous periods of time must have gone by to develop all the beauty and splendour of this so varied and so highly organised life. My thoughts range over far distant times. I see, looking so near that it seems as if one could touch it with one's hands, one of the mightiest volcanoes of our earth gradually unveiling itself and stripping off its robe of clouds. The volcanic regions below it remind me of the story of how all my surroundings were developed.

Born in fire, and evolved, differentiated, and formed to

1 It appears that the explorer completed some of these sketches after his return with the help of stuffed specin:ens, but he drew others entirely from nature on the $A$ frican velt. 


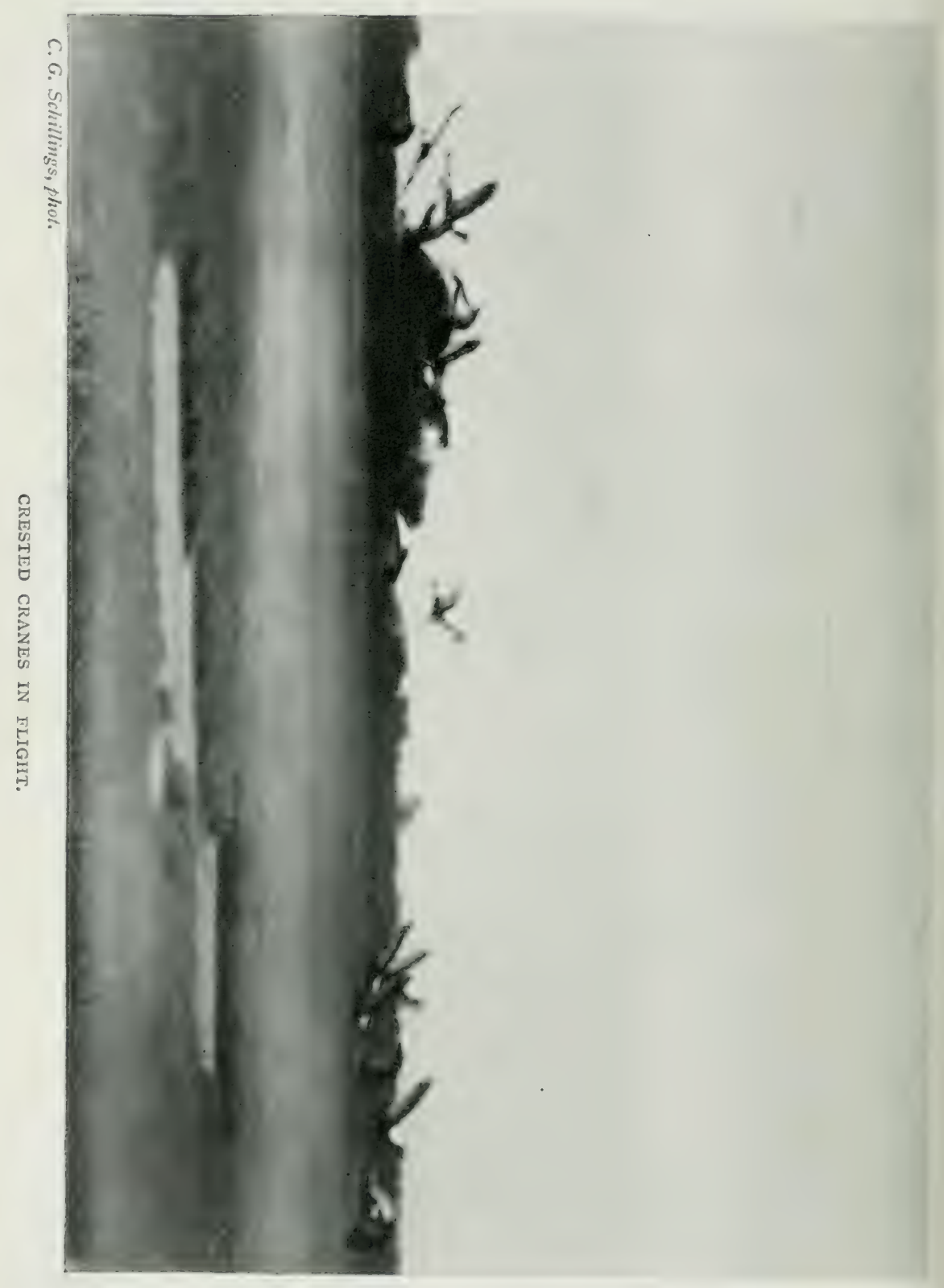




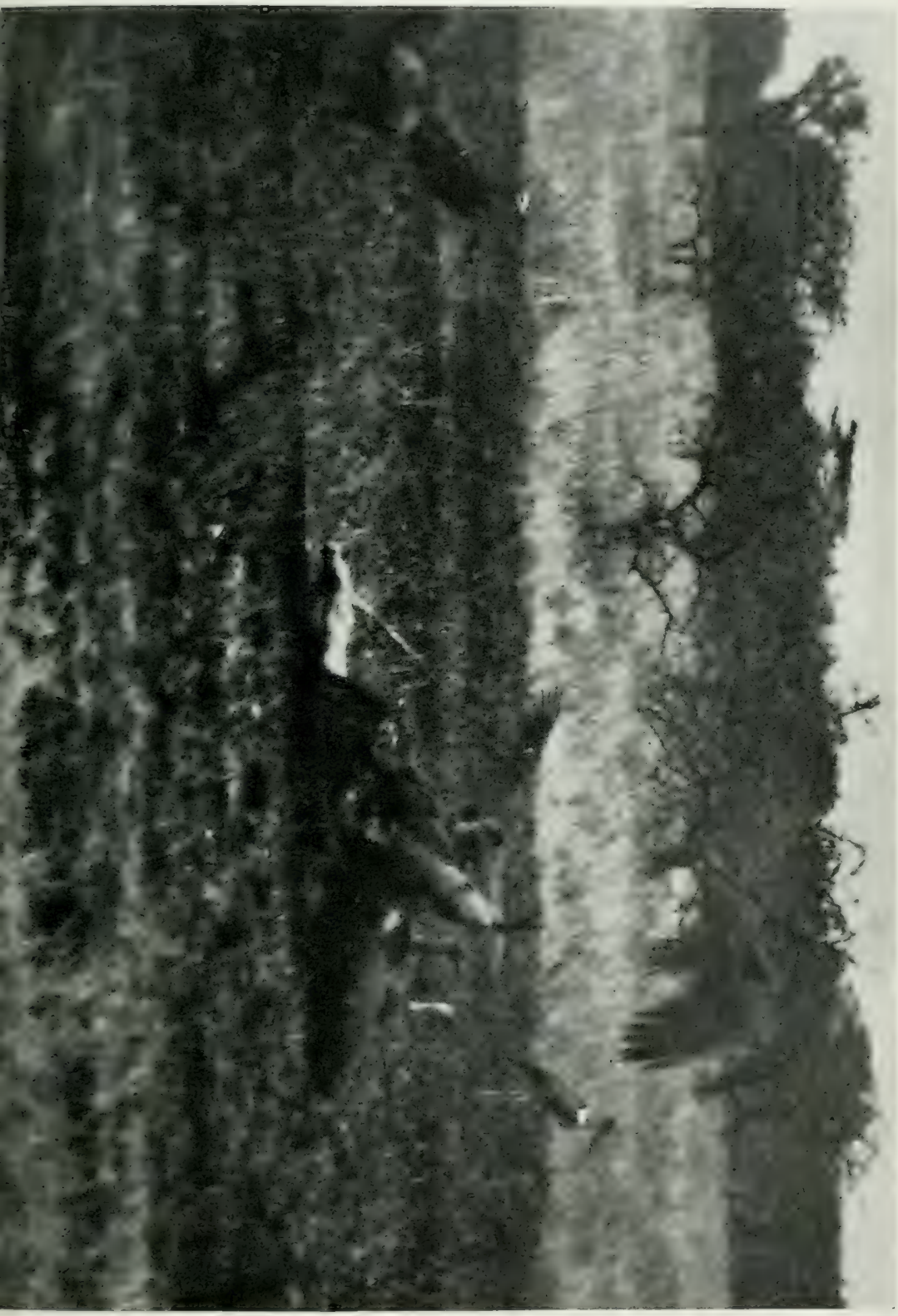



so much beauty, which no hostile hand has yet come to destroy, the scene around me is so splendid that my eyes keep ranging over it, more and more eager to contemplate all its sp!endours.

A strange feeling comes over me. I think of all the beautiful spots of our old world. They have all been taken possession of under carefully devised arrangements and methods, well protected by the eye of the law, and often only occasionally open to access, and then on condition of payment. But the beauty I am contemplating has now been hopelessly abandoned to intruders, who have neither know'edge nor taste nor sense, and who are at this moment so barbarously destroying it.

But these thoughts must give way to others that are more pleasant and consoling. How wonderful to be able to revel in this wilderness, to feel in oneself the influence of all these splendours, notwithstanding all dangers and all difficulties, however great! Everything around us undulates and shimmers, bathed in a dazzling sea of light. Gradually the colouring of plain and hills, the dome of the sky and the whole surrounding landscape, changes to duller and less definite tints. The sun-illumined air rises in waves from the earth, and the various strata of it form an ever-changing chaos of reflected light. Over all there is deep peace. A spell that accords with the mood of the moment seems to stream down from the dome of the sky over this solitude, lying so far from the noisy activity of the world.

All that I here behold has been going on since those far times, directed by natural law, in ever-recurring 267 


\section{In Wildest Africa}

succession. But to-day for the first time a member of the complex society of civilisation takes delight in this mountain rising amidst all this primeval beauty.

Who could possibly set down this poetry upon paperthe poetry of the relt and its wild inhabitants, the moods of East African Nyika? The master of colouring has not yet arisen who could give us a picture of these mighty gatherings of wild herds, and of these deserts that seem overcrowded with animal forms, that yet live so peacefully together, nor can the master of the pen, though he may have been able by his words to conjure up some idea of them in the mind.

One who has perhaps felt and enjoyed their spell more than any one else is Alfred Brehm. But he has travelled only in regions that had long been under the influence of man and his activity. He has only once seen the king of beasts, and has never looked upon the giraffe-whose beautiful eyes the Arab compares with the eyes of his beloved-and many other forms of the African fauna. ${ }^{1}$ Nevertheless he has done wonders, thanks to his deep feeling for his subject, his intimate understanding of it. and his incomparably poetical power of description. He hats given us imperishable pictures in words that are among

${ }^{1}$ So too, for example, Wissmann never killed a lion. This is sufficient proof of the difficulty of observing animal life. The author may take this (1)prortunity of calling attention to the remarkable work of this departed explorer, In den Wildnissen Afrikas, and thinks himself fortunate in the possession of a letter from his hand approving of his method of observing animals. This letter expresses in words that go to the heart the love for and understanding of the beauty of the African fauma that characterised this successful and distinguished explorer. 



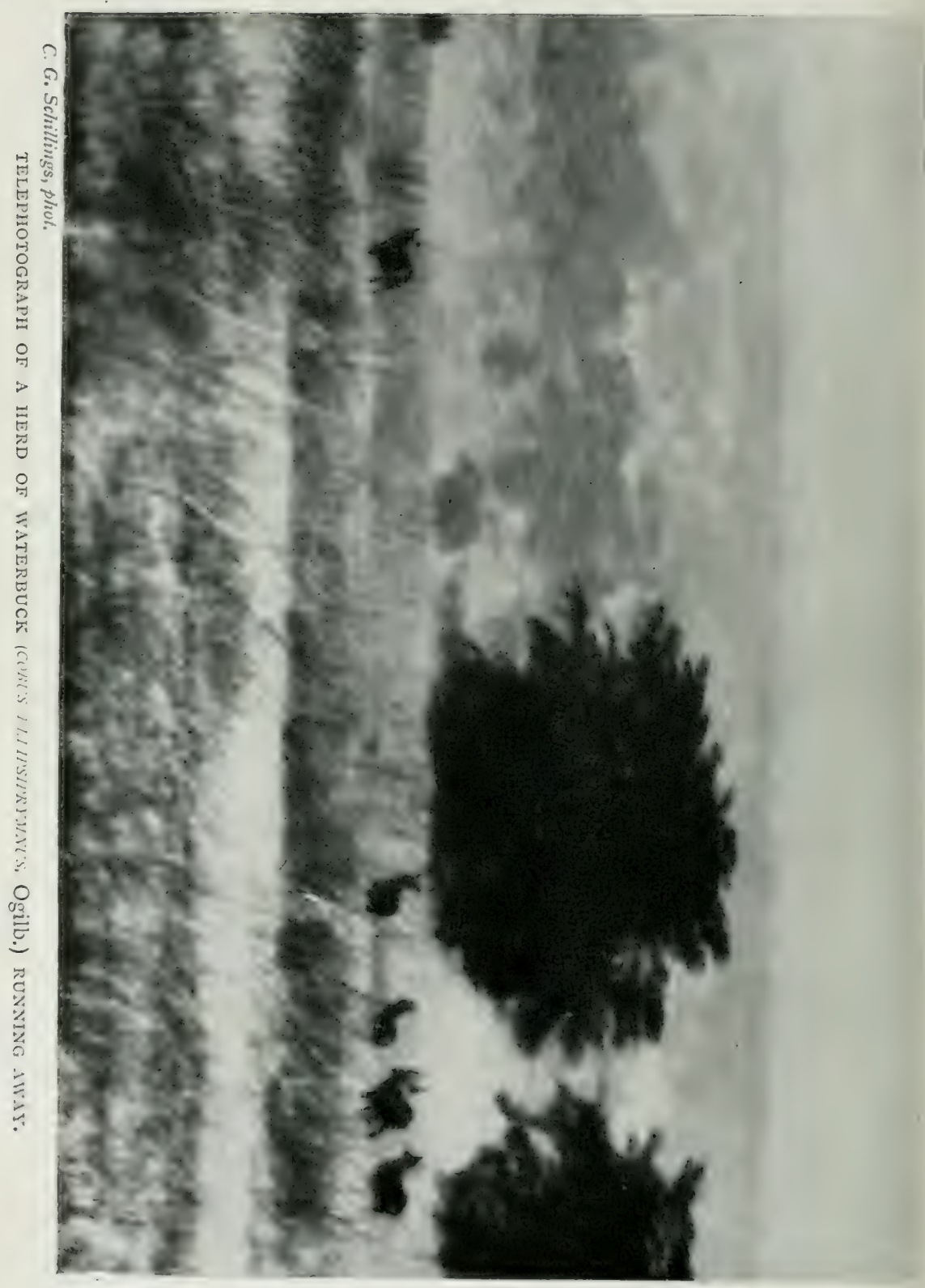




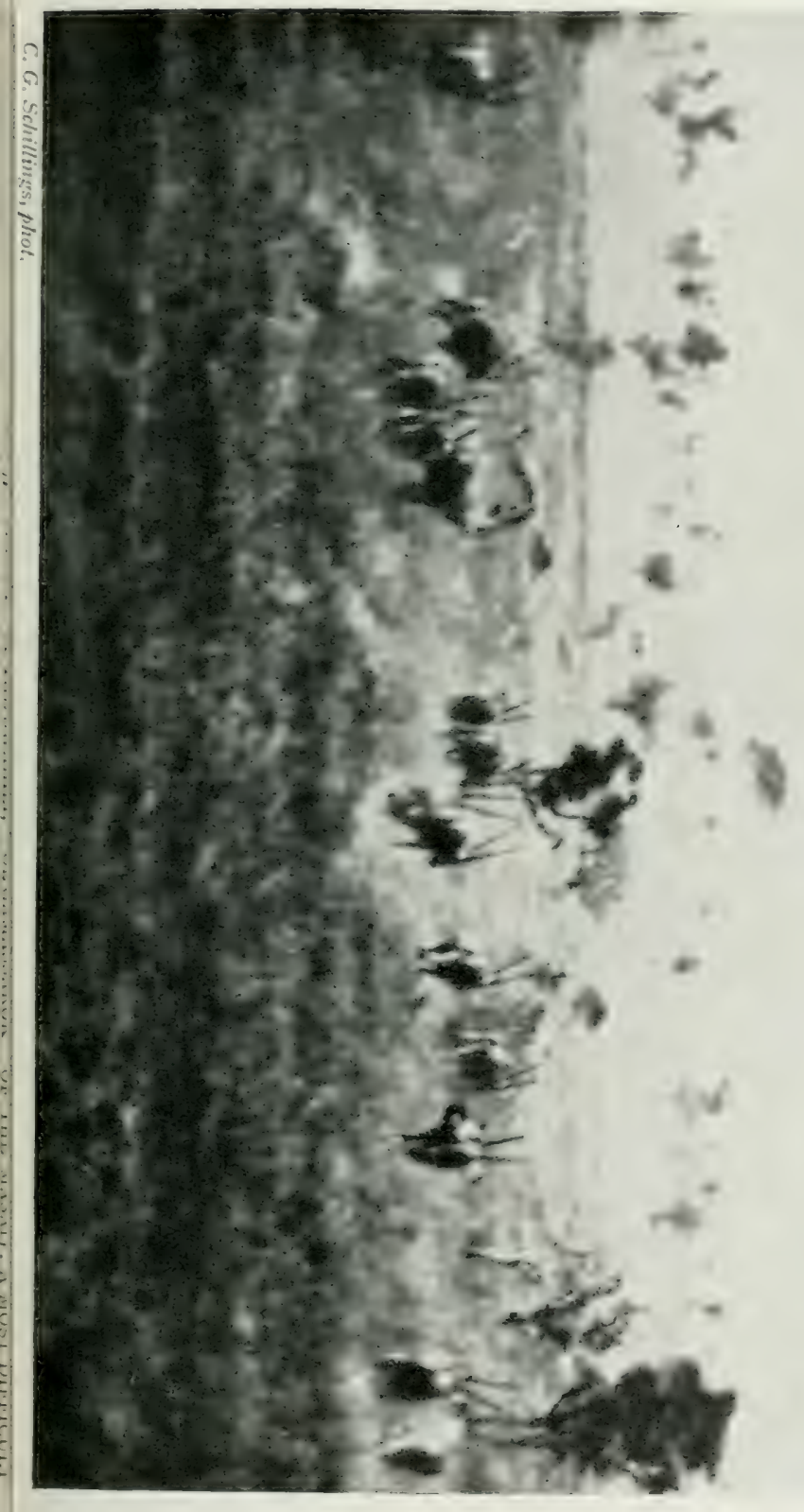



the most beautiful that have ever been written about Nature. Our old famous teacher, Dr. Schweinfurth, has seen and described similar scenes. With these two we may rank in equal honour the name of the German explorer Richard Bühm, ${ }^{1}$ who unhappily lost his life so tragically and at such an early age on the shores of Lake Upämba in Southern Urúa, of which he was the discoverer. Many others might also be named who were deeply influenced by these primeval splendours. But the fauna of South Africa has vanished unsung and unfamed, before any artist or master of words arose to place in a fitting way its beauties on record for all time!

Masters of words like Ludwig Heck, by whose skilful pen the life of the mammalia has been lately described anew for us in Brehm's Trerleben, and like Wilhelm Bölsche, would perhaps have been capable of grasping and reproducing the impressions that the traveller feels in those far lands. But they have never trodden these distant countries, and they must therefore confine themselves to describing artistically and yet truly what they have never actually seen, from ideas based on their own clear understanding of the observations of others.

The sun is setting. It is time for me to come down from my hill and return to my camp. The sun goes to his rest in flaming splendour, there is a glowing radiance of violet and purple light ; soon dark night will surround

1 Take, for instance, his description of the Ugalla River in a letter to his grandfather, General von Meyerinck, in his work Von Sansibar zum Tanjanjika (published by Hermann Schalow, Leipzig, I 888).

VOL. I

273 
me. Thoughtfully I tread my homeward way, with my mind richly stored with impressions, but anxious as to my efforts to describe all that I have seen, and doubtful as to my success.

"To have passed a thousand and more days, it thousand and more nights in the wilderness with a great longing in my heart in some way to grasp and make my own all the splendour I have seen and all its charm; to have again and again delighted in the beauty of the Nyika: this does not make me capable of reproducing it. And even if after many decades of years I could fully comprehend it, I should never succeed in reproducingr it in its full significance and bringing it home to the minds of those who have never looked upon it with thei own eyes."

So runs a passage in my diary.

Descriptions of things similar to those that I have told of in inadequate words in these slight sketches of the Nyíka district of East Africa may be read of other regrions of our earth. The life and activity of the Arctic fauna, of those gigantic creatures of to-day, the whales, and of the Polar bears, the musk oxen, the wild reindeer, the walruses, the seals - those most sagacious creatures-and the life of many other animal forms-all these together are waiting for the hand that will describe them in word and picture and put on enduring record for all time this changing life. Thus only will a new existence be given to those forms of life for which the sentence "Vae Victis!" has gone forth,

May the master soon appear who will be able to 274 



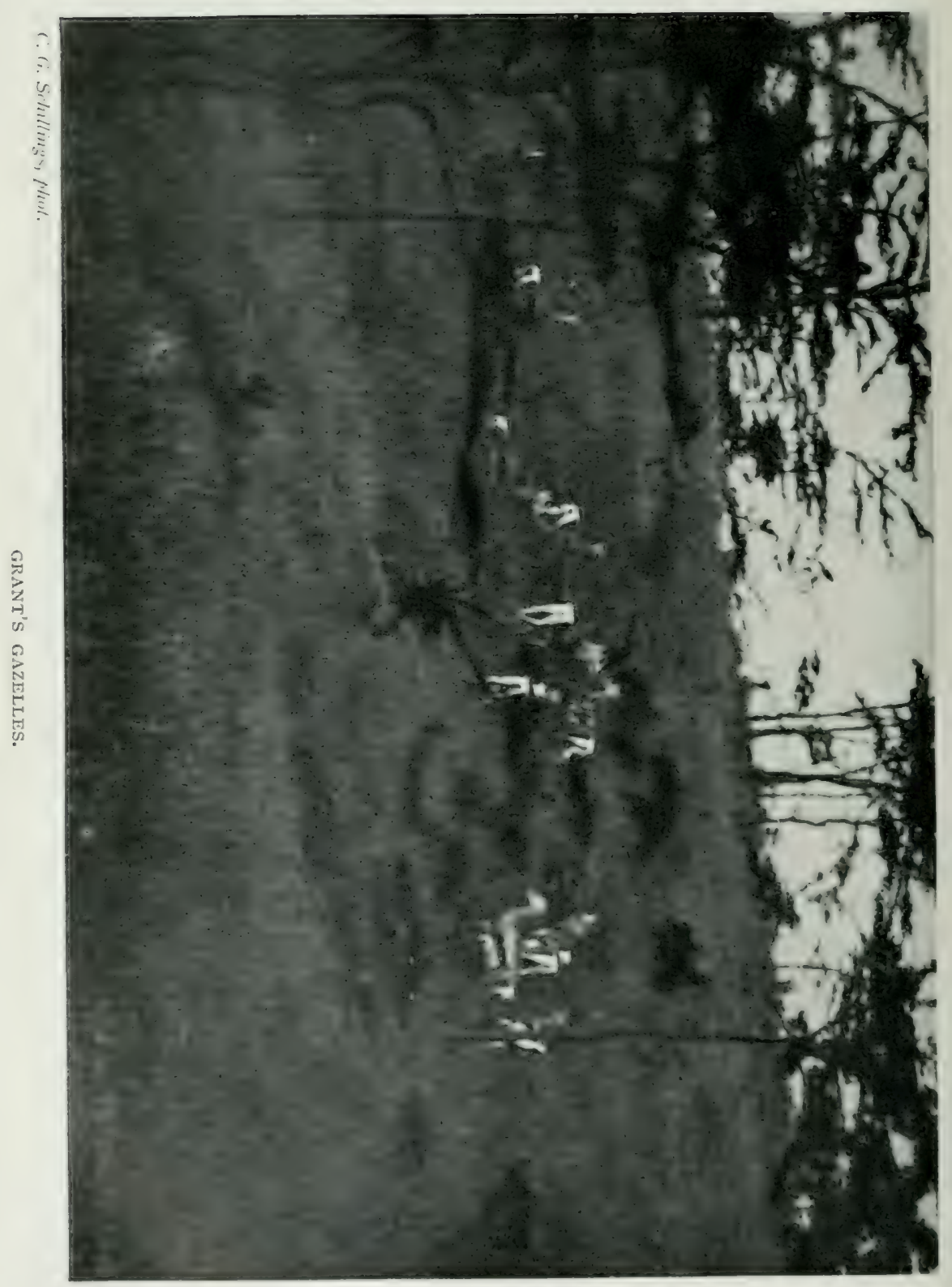




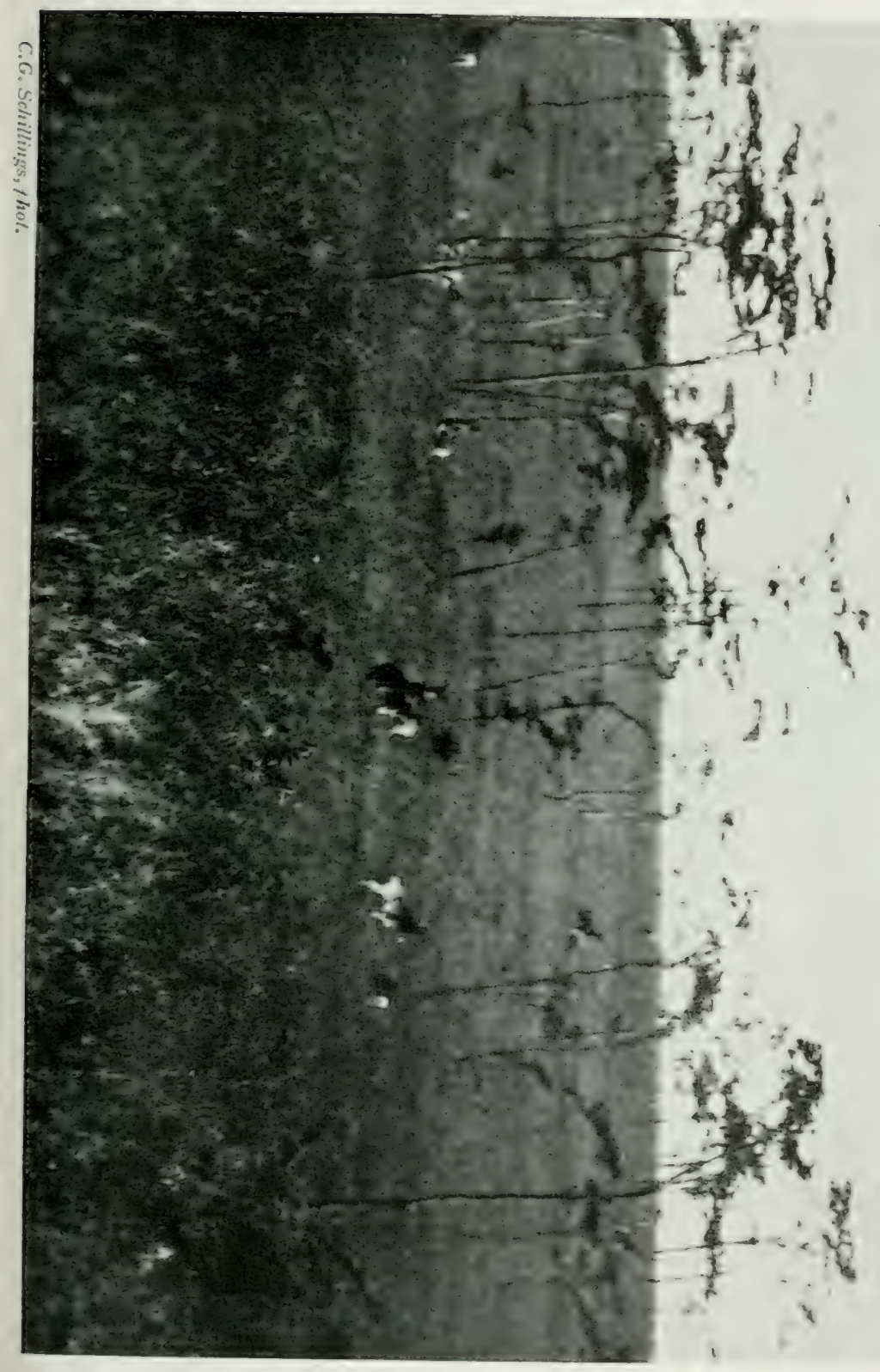



Pârelegares

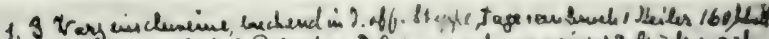

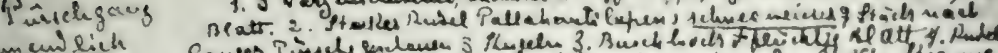

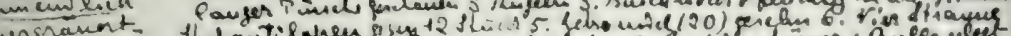

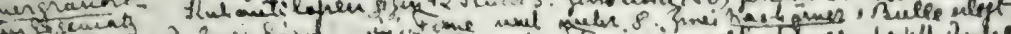

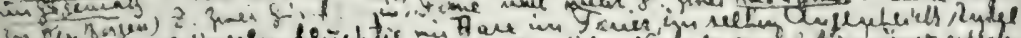

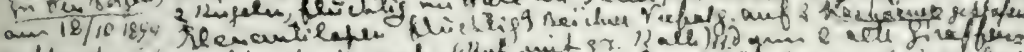

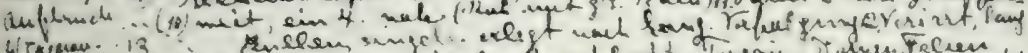

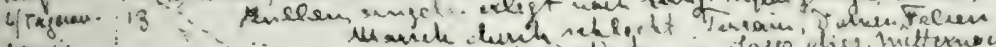
nimidides

nitruedt:

geger thas?

gin mu:

Leshents

Iaurrenge:

ment wint.

inim 24

dicet ans

sacer nate

dumpel.

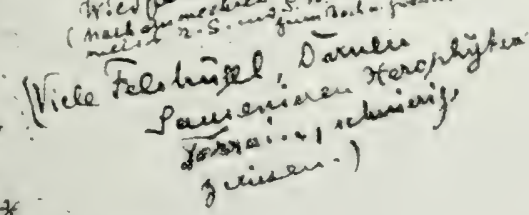

130 is erivicht.

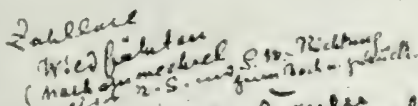

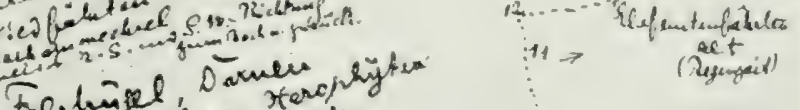

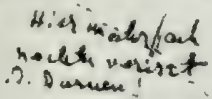

$\operatorname{rin} 12 \lim 12 \%$

Sinclf-Butar nexplot

Filute 18. 18

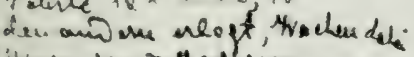

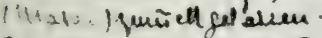

Selr lisu, matreongin

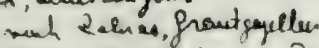

Simate th serelein hi $x$ in Durtese

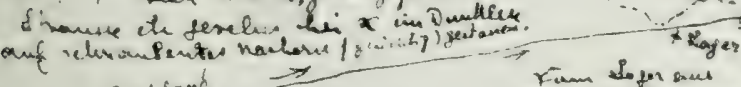

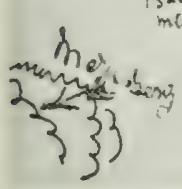

W. $\operatorname{to}_{\mathrm{s}}^{\mathrm{r}} \mathrm{o}$

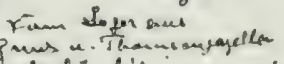

$$
\begin{aligned}
& \text { Joly kimbig in th }
\end{aligned}
$$

Qeforianters forch $(6-8)=-4)$ 


\section{In Wildest Africa -}

is now descending on the wilderness, so will an everlasting night soon come down upon all the life and movement that I have tried so inadequately to describe in merest outline.

About a century ago the "Twilight of the Gods" (Götcrdiummermgr) began for all the wild life of the Cape region of South Africa. Even before these hundred years had run out it was ended; this abundant flood of life had disappeared. . . .

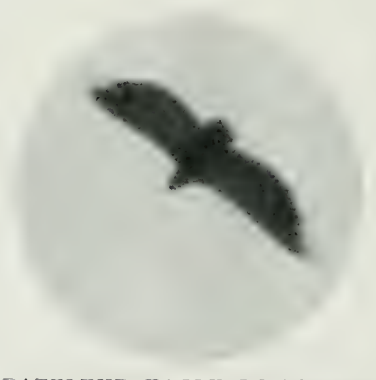

BATELEUR EAGLE IN FLIGIT. 


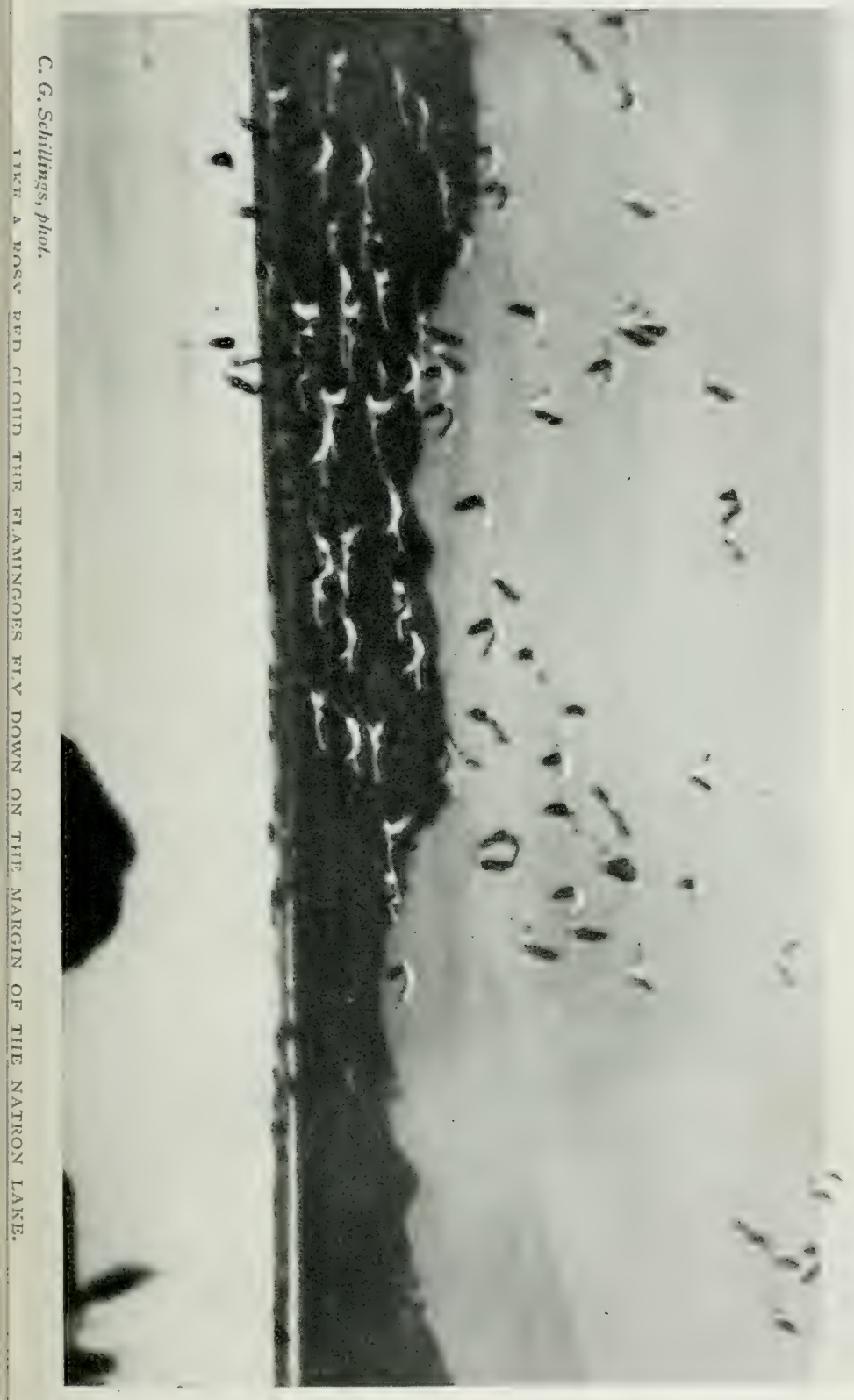





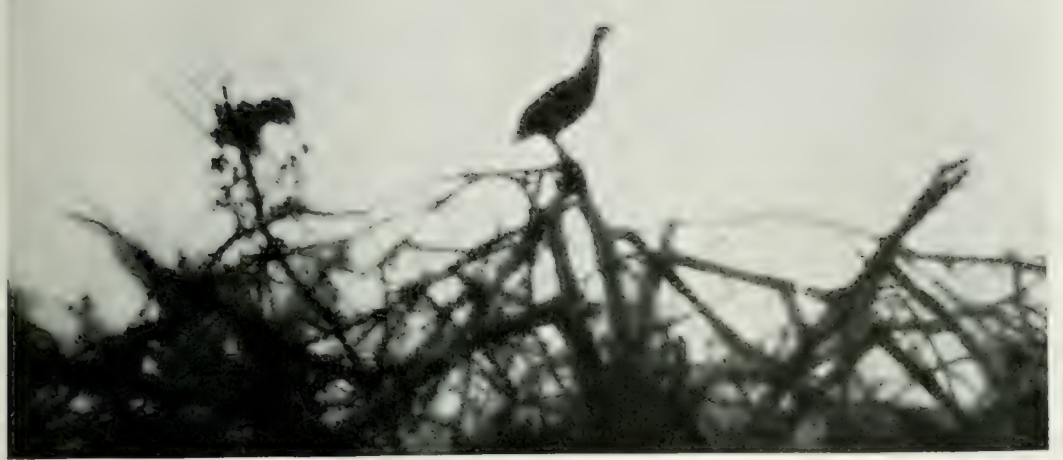

A FRANCOLIN PERCHED ON A THORN-BUSH.

\section{VII}

\section{The Voices of the Wilderness}

THE German sportsman knows well the mysterious 1 charm that speaks to the listener, when in the woods in spring he hears the note of the woodcock and the cry of the ptarmigan, and when in autumn he hears the call of the stag to its mate. It must be that the listener is subject to some atavistic influence, some impulse rooted in the dim past now quickening into life.

Let him who understands this charm follow me through the equatorial wilderness, and listen with me to the music of songs and notes that we may call the language of the Nyíka. We shall hear it there on every side, by day and by night. True, fully to understand this language one should have King Solomon's magic power, which made its possessor understand the speech of animals, or like Siegfried have dipped one's hand in the blood of 283 


\section{In Wildest Africa}

the dragon, and thus have acquired the gift of holding converse with the birds.

This much is certain, in the wildernesses of Africa this primeval language is still to be heard. In our hunting grounds at home the voices of the aurochs, the bison, the ibex, the bear, the lynx, and the wolf have been silenced, and many other voices that have belonged to the wild open country since primeval days have all but died away. I have indeed learned to understand only a few words of this language of the wilderness, though I have heard thousands of its sounds. But I may be able to tell something about it.

What a strong and deep impression this world of sound makes upon the traveller at so many hours of the day and night! Every region, every different kind of country has its own characteristic harmony. One does not always hear it-it depends upon the season of the year and the time of the day, on the changes of weather, and much else. But when one has become even to some small extent familiar and conversant with these various voices, one enjoys this music-language of the Nyika with at sense of deep delight and ever growing understanding. Sometimes it is most difficult to find out the names of the individual speakers. Often they keep very quiet; they seem to be like great vocalists on tour: they appear suddenly, and then disappear again for a long time, without letting one see any more of them. Then the traveller may often listen long, in vain, for the singergone without leaving a trace behind. But it is not only the soloists that charm us. There is also the combined effect 284 
of all the voices of nature uniting in one vast impressive chorus. This has made such an impression upon me that I shall try, so far as my limited powers permit, to describe it to the reader. This musical language of the wilderness is in itself powerful, rich and impressive, but all this in a still greater degree for him who, observing things with the eyes of a seer, knows many of the voices that resound in it will not be heard much longer. Although for long, long ages, through hundreds of thousands of years, this tumult of sound has been heard, these voices, or many of them, will soon be silent victims of civilisation! They are going, and with them many of the euphonious names of places with which the natives have distinguished every spot, but which the Europeans, as they penetrate into the country, feel themselves obliged to change.

It may seem that I myself am not quite guiltless of such misdeeds. It is true that I named an island, that resort of the wild buffaloes in the Pangani River, "Heck Island," in honour of Professor Ludwig Heck. But the island had till then no name whatever. One feels sad, on glancing over the map of Africa, to note the degradation of so many old traditional names, which is in no way justified, and is a sign of the hasty and violent introduction of civilised life. "The Boers are not people who think much about natural history," says a writer somewhere. And in fact, through their agency, the euphonious names of the various wild species of South Africa are now to a great extent already obsolete. They hastily gave vulgar-sounding names of 


\section{In Wildest Africa}

their own to the wild animals. ${ }^{1}$ Thus the oryx antelope became the "gemsbock," and the cow-antelope, because it was tenacious of life and difficult to kill, the "hartebeest." The gnu, on account of its wildness, was called the "wildebeest," the bustard the "pauw," " the hyena the "wolf," and the giraffe-incredible though it may seemthe "kameel"! Hand in hand with this went the changing of place-names: so we read of "Hartebeests Fontein," "Olifants River," "Kameeldoorn," "Zwartkop," and we have a whole series of unpleasant, and sometimes utteriy ugly names by the introduction of which the beautiful aboriginal names of various places have become obsolete. Thus not only do the primitive inhabitants of the land disappear, but their names, too, are blown away upon the wind.

Countless are the voices that resound by day in the Nyíka. But by night these voices speak still more mysteriously and wonderfully to him who listens to them, bringing him into still closer union with nature. From the multitude of these voices I choose a few only.

Old memories come back to me! It is in the year 1896. I have just landed, and am sitting in my night shooting-encampment by an inlet of the sea near Dares-Salaam. A concert of the voices of nocturnal birds mingles with the sharp buzz of the mosquitoes. Again and again one hears a strange cry. Unspeakably sad and monotonous, this peculiar sound rings out over the

1 Unfortunately such ridiculous and ugly names as gemsbock, hartebeest, wildebeest, etc, have gradually come into general use.

- Pana is Dutch for peracock. 


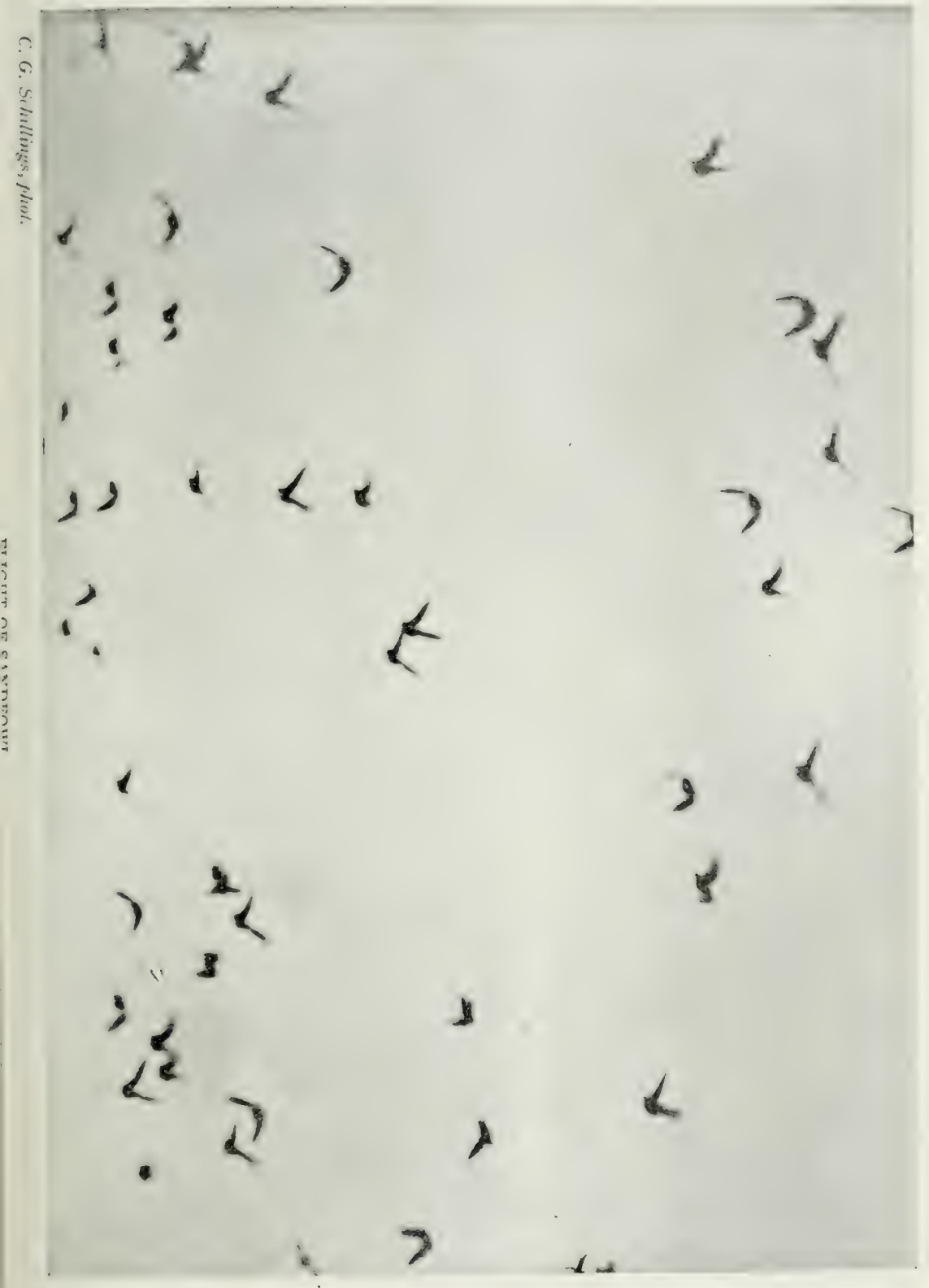



waters of the inlet; in the distance a changing answer comes back in response to it.

I did not then suspect that it would take me nearly a year to be absolutely certain that this sound was uttered by an extremely shy and restless kind of cuckoo!

This sound of the African night always made the strongest impression upon me, and remains indelibly in my memory. All that one heard from near at hand, or from the distance miles away, had its origin not in man's voice or in human activity of any kind, but must come from birds and beasts to a great extent unknown to us. One had to interpret, to conjecture, to build up thecries. Often one struck upon the correct solution. But often enough, too, the interpretation one accepted proved to be false, and then one's anxiety to find out the true solution, aroused anew, was doubly keen. The first time I heard it, I had no difficulty in interpreting for myself the cry of the monkeys harassed in the night by leopards, a screaming of a kind one cannot easily forget, plainly expressing the greatest terror. The first time one heard the neighing of the herds of zebras it was much more difficult to recognise the sound, and the gobbling cry of the ostrich had at first a still stranger effect. But as soon as I had heard the voice of the zebras a few times, it was clear to me that the extinct quagga of South Africa must have derived its name from its cry. If one puts the accent on the second syllable, and pronounces the $\delta$ softly and deep in the throat, one has, as one repeats it, a wonderful TOL. I 


\section{In Wildest Africa}

reproduction of the cry of the zebra as I heard it myscif.

What a pity that all this cannot be put on permanent record by some such apparatus as a gigantic phonograph! But unfortunately we are still a long way from such a possibility.

No one will be surprised at my leeping specially in mind that endlessly melancholy cry of the cuckoo in the darkness. How lonely and empty our German woodlands would seem without the cuckoo and the cuckoo cry! As a matter of fact the African primeval forest never. hears the same cry that has become so dear to oursclves. Our cuckoo, migrating in a few days all the way from the north to the equator, flies in restless haste through wood and plain, but he is silent. His cry is heard only in our country at home. But in the East Africa district of Pori, amongst many other cries those of two species of cuclioo are heard in rivalry. These are the sickle cuckoo-the "Tipi-tipi" of the Swahili-a reddish-brown fellow that flutters in heavy flight everywhere about the bush, the reedy bogs and hill-slopes; and the solitary cuckoo (Cuculus solitarius, Step.), about whose cry I was for a long time mistaken. The unceasing, low cry of the former, the sickle cuckoo, if it is heard even a few times, can never again be forgotten. It sounds like - "Dut-dút-dududu-dut-dút." One hears it by day and also in the darkest night, contrasting strongly with the

Cf. Prof, P. Matschie, Die Sïusctiene Deulsilh-Ostufrikas ("The Mammalia of German Last Africa "), p. g6, and my work IIth F/eshlight and Rifle. 
sharply defined, clear note of our European cuckoo, though the latter listens in silence to the cry of his cousins all through the winter under the equator. This cry seems to me, with its low, dull, softly prolonged tones-so different from the louder cry of its northern relativeto be quite in keeping with its mysterious tropical home. For the sickle cuckoo knows all its deepest mysteries, and no bird ranges so unweariedly through the densest thickets and over the most inaccessible regions. In the most hidden, solitary, and unknown spots ${ }^{3}$ it would come fluttering up from the ground at my feet, often startling me. It seemed to me as if the bird wanted to call my attention to newly discovered mysteries, as its "Dut-dútdududu-dut-dút" came sounding to me, now here, now there, low, soft and melodious, by day under the brooding noonday heat, and just the same in the midnight hours.

At night, too, he is seconded, as I have already mentioned, by his more timid cousin, with an ever repeated "Ki-kü-kü-kí-kü-kü," that resounds monotonously in the distance.

There is a strange charm in continually hearing these voices again and again, without knowing the little singers; and a triumph at last in making out which they are.

"During a sleepless night," said Richard Wagner, "I once went out upon the balcony of my window on the Grand Canal at Venice. As if in a deep dream the legend-haunted city of the lagoons lay spread out before

1 From the Cameroon district in West Africa Professor Ingwe Sjöstedt writes to me also of a nearly related species of cuckoo that has much the same cry. 


\section{In Wildest Africa}

me under the darkness. Out of the soundless silence there came the loud call of a gondolier waking up just then on his boat... then from the farthest distance the same call answered back along the dark canal; I recognisced the old, melancholy, melodious sounds, doubtless as old as the canals of Venice and their people. After a solemn pause the far-sounding dialogue at last began, and it seemed to me to melt into harmony, till the notes heard close at hand and coming more softly from afar died away as sleep came back to me again."

Who could describe in such noble words the impression made upon our minds by the spell of the sounds and songs of the nocturnal wildness, and all its strange and beautiful music? All that at first is strange there, and even alarming, comes gradually to be something one loves intimately. Shall I ever be able to listen to it all again? Who knows? Let me try then to make some record of what I have so often heard, and in these few sentences attempt to give some faint echo of these once familiar voices.

We are in the midst of the great forest. Giant podocarpus and juniper trunks rise up towards the sky. It is cool and shady all around us here; we breathe a moist, and not unfrequently a musty air. The sunlight plays only upon the tops of these giants of the primeval woods, and can but scantily illumine the almost bare ground below them, sending here and there shimmering, dancing rays of light amongst the trec-trunks. High overhead the giants arch their branches, interlacing them in a vast living roof of green. Only where clearings 


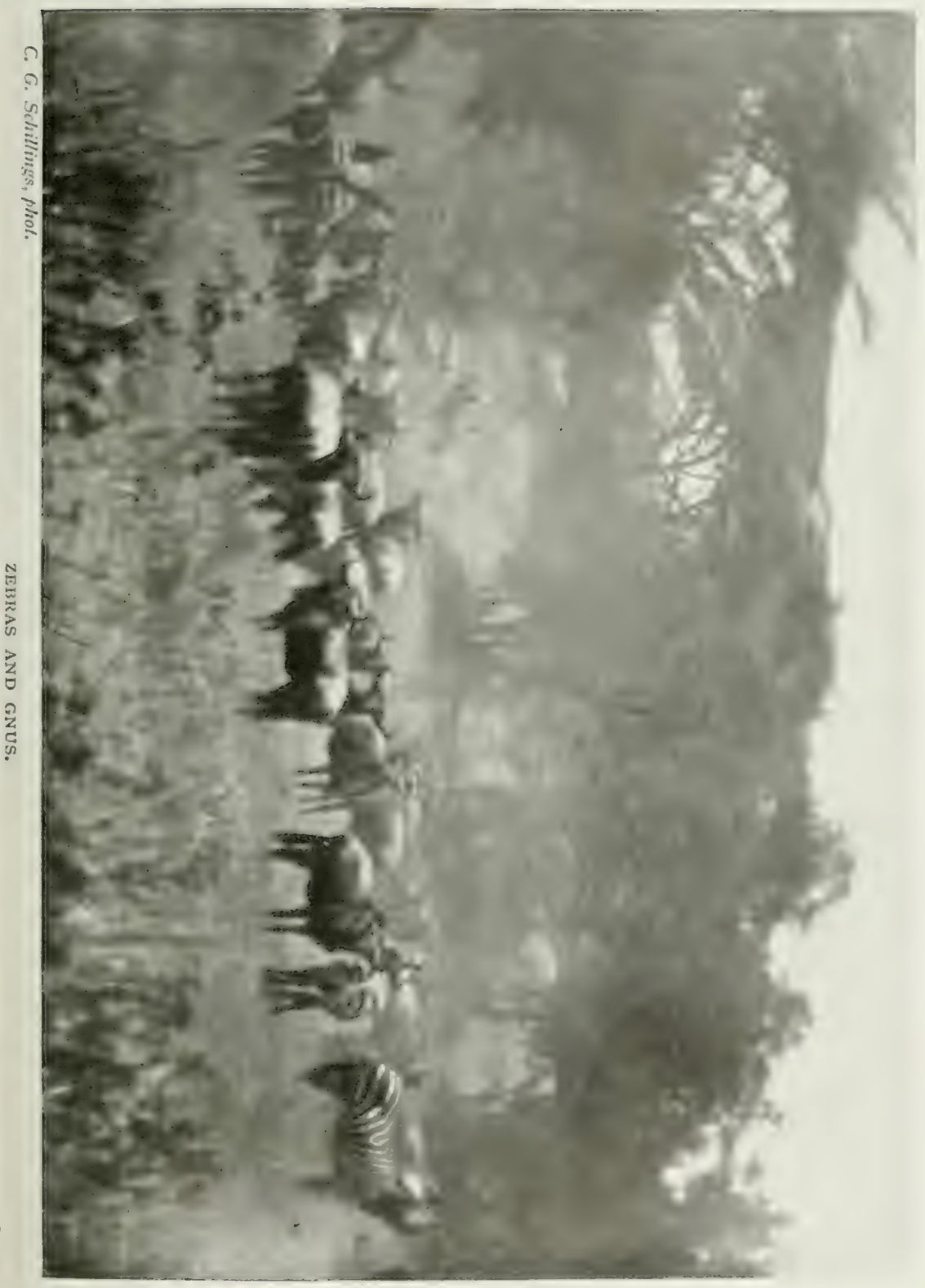



make a break in the mass of trees, a sea of light floods all the ground-a flood of light so strong that our eyes, accustomed to the obscurity, the mysterious semi-darkness of the forest, are dazzled, and there comes to our minds involuntarily recollections of old Bible pictures, in which such floods of light are shown streamirg down from heaven to earth. A confusion of trees, creepers and undergrowth, with amidst it uprooted tree-trunks lying mouldering away; the earth black, and often marshy; no road or way far and wide, but only here and there the tracks and beaten paths made by the elephants and rhinoceroses that have roamed the old forest since primeval times.

Deep silence all around. If the traveller stands still and holds his breath, this silence seems to weigh down upon the soul with a weird force. At such moments it is as though some vague disaster threatened, or something wicked and dangerous were creeping around unseen.

Suddenly, a squealing and chattering. There is a scurry up and down the tree-trunks, and again there is a strange sound of spitting and growling. Just now there had come over us a feeling such as is expressed in Böcklin's ${ }^{1}$ masterly picture, directly inspired by nature, Schrueigen des Waldes (the "Silence of the Forest"). We had almost expected each moment that legends set before us by the power of his genius would here become

${ }^{1}$ Franz Hermann Meissner in his work, Amold Böcklin, says: "I have often found that I had to consider these pictures with the blue eyes of an old Ostrogoth seer of primitive days." And I am of opinion that in order to take full delight in the charm of the tropics one must look on them with northern eyes. 


\section{In Wildest Africa}

realities; we felt that here one might surprise nymphs and dryads. The spell is soon broken. The gnomes of the primeval forest, the tree-climbing hyraxes, have scared away the silence. Wonderful to say, these dwarfish hoofed anmals, the nearest still surviving relatives of the rhinoceros, are here scrambling up and down on the trunks of the venerable trees.

From all sides, from every spot, every direction, there resound the same cries, and again there is silence all around us. Here, far in the depths of the primeval forest, the bird world seems to have no home. But hark! I hear a curious chirping, and I notice on a bare bough above me one of the most gloriously coloured of African birds, the bandeat trogon (Heterotrogon attatum. Shell.), which, uttering a most peculiar sound, is carrying on its characteristic sport--flapping its beautiful wings.

Then loud-sounding trumpet-like notes break on the ear. IVe hear a rushing in the air, and big hornbills with their huge beaks come sailing, as I judge by their cries, through the air, and alight on the top of a giant juniper (/uniperus procera). They, too, fly away after awhile; their trumpeting dies away in the distance, and again there is silence all around. Their voices and that of the brightly coloured helmet-bird give to the primeval forest of Africa a strange charm that is all its own.

But now there suddenly breaks forth a remarkable sound, rising and again falling as I listen, a strange music of a most peculiar kind. It is the chatter of the colobus monkeys, a sound that cannot be described in words. 
A party of these wonderful creatures seems to be in good humour, for their song comes to me in chorus unceasingly, and in rising strength. "Nurúh-murúh-murúh-rrrrrrmúh rrrrrrmúh-murúh quoi-quo-quo-quo-rrrr," it sounds, now swelling strongly out, now gently dying away. These, too, are doomed to death, who now are letting us hear their primitive song, that in our days may so easily be

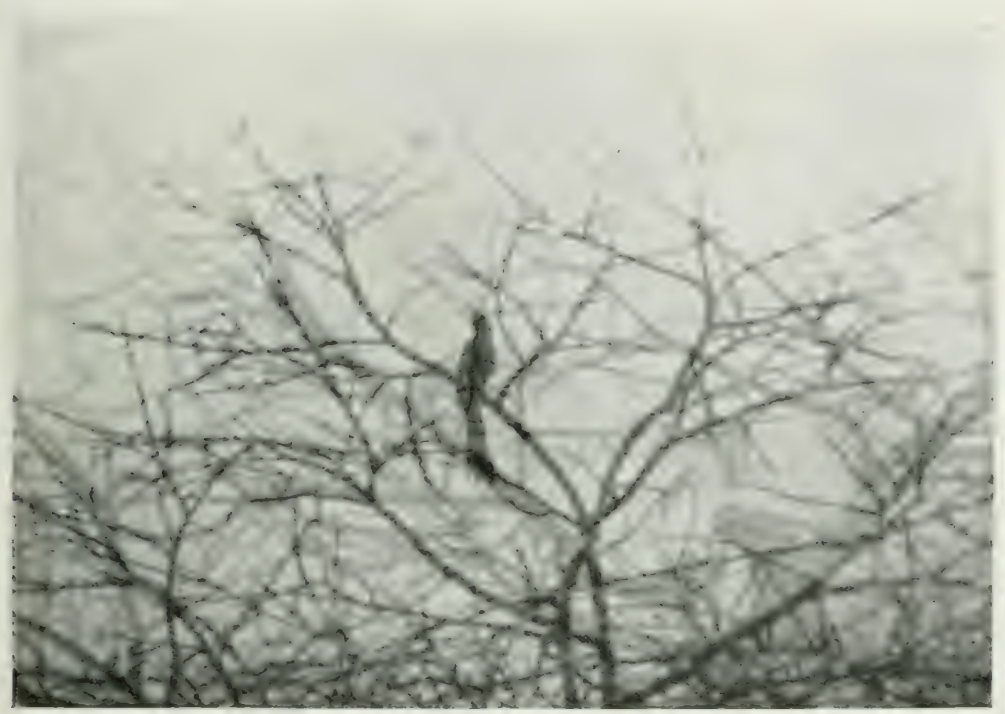

AN ALARUM-TURACO CHIZAFRHIS LEUCOGASTRA IN ITS PLACE OF SAFETY AMONG THE ACACIA THORNS.

their death-song; for these monkeys are keenly hunted for the sake of their beautiful fur, and their song often betrays them to the hunter, eager for their spoils. Some poisoned darts, which I find here with points as sharp as needles, and which were once shot with a bad aim at the little monkeys, are evidence enough of this. And again I hear the great wood ringing and echoing 


\section{In Wildest Africa}

with the countless cries of birds. There was a time, too, when the call of millions of the now all but extinct passenger pigeon resounded in North America; so, tooand of this I have no doubt-- the cooing of the ringdoves was heard repeated by thousands of birds in our beech and oak woods at home when the acorns and beech-nuts were in season.

On the lonely uninhabited western slopes of the highest giant mountain of the German possessions, Mlount Kilimanjaro, certain forest fruits flourish in profusion. There is heard on every side a strong, sweet-sounding dove-note, like that of our ringdove. A handsome large species of wood-pigeon (Colmmba aquatrix, Tem.) has gathered in hundreds of thousands. The rustle of their wings, as they rise or come down in great flocks, mingles with their beautiful calls and cries; the ear can hear nothing else. Voice, form, and movement so strongly remind one of our own ringdoves that one feels carried away to far-off, familiar scenes, and the illusion is helped by the character of the Kilimanjaro landscape, which in certain of the higher regions has less of a tropical than of a northern aspect. How strange it is; the cry of this bird all at once transports the traveller to his own land! Truly there is a magic in somd. With the poorest appliances, the slightest equipment, the creative fancy can in a moment build a bridge to the Fatherland. The call of this beautiful dove sounding here on every side, its love-inspired circling high in air above the tops of the giants of the primeval forest, surrounds it with a dream-picture, and makes me suddenly breathe the air 296 
of the beech woods. I am in the northern woods in springtime; cool and fragrant the northern air blows round me. But ah! thousands of miles of land and sea divide me from all that, and cool reflective reason counts only on the possibility, not the certainty, of my ever seeing my native land again.

And yet this beautiful picture has a strengthening and consoling influence. It drives away the trouble of home-sickness-a dismal thing!

I can hear many other voices besides these in the primeval forest. But those that impress themselves in the most completely enduring way on the memory are the strange cry of the tree-hyrax, the peculiar note of the hornbills, that calling of the doves, the remarkable chorus song of the 'Mbega monkeys, strange beyond all description, and the trumpeting of the lord of the primeval forest, the elephant.

Another tone-picture - an early morning at a drinkingplace in the desert. One could feel the cold in the night, but the quick coming warmth of the equatorial sun's rays has soon roused the animal world to active life. There is the cry and call of the francolins on all sides. But the chief part in this early concert is taken by the thousands of turtle-doves, flying from all directions to the water. Everywhere a murmuring and cooing, that the Nasai are able to re-echo so incomparably in the name of the turtle-dove in their language-" Nclurgulyu." As an accompaniment to this, there is the rustling and wing-clapping of all the feathered visitors at the water. Towards evening the air in the neighbourhood 
of a much-risited drinking-place is literally filled with these beautiful and swift-winged birds. The rustling and beating of their wings in rapid flight makes in itself a concert. I not unfrequently came upon places that bore the name of the "Doves' water," or the "Doves' restingplace." All the various voices of the many species of doves that find a home in the Nyika resound again in the traveller's ears for years after. Whether it be the strange voice of the parrot-pigeon, that ushers in the concert with a hollow "Krūh-krūh" and follows it up with some remarkable notes, or the melancholy cry of the little steel-spotted pigeon that comes to us from the thickets, or the strong, loud-sounding love-notes of the already-mentioned Columba aquatrix, Tem., so like our ringdove, or, above all, the familiar sweet voices of the many small kinds of turtle-doves-all these sounds, the rustling and fluttering and beating of wings, the living, moving picture presented by all these beautiful birds, belong inseparably to the essence and being of the Nyika. When the turtle-doves greet the morning with their soft cooing, their call is answered from afar by strange guttural tones borne swiftly through the air, sounding like "Gle-glé-lágak-glé-ága-ága," from the veltfowl hurrying like themselves to the water. Brehm, in his Leben der lögel, has already raised a poetical monument to them made up of beautiful lines. But I could not picture to myself the morning concert of the bird world in the Nyikia without the strange cry of the sand-fowl and the cooing of the doves, and the peculiar sound of the beating wings of the relt-fowl as 
they rise in scattered llight from their resting-places, - a sound that impresses itself strongly and distinctly on the ear, more than that of any other bird I know, as the "Kláck-kláck-kláck" of the rising woodcock strikes the ear of the sportsman in Germany.

The wonderful flight of the velt-fowl, their calls and cries, their hurry and bustle, afforded me ever new interest. It always seemed to me as though the wide wilderness here sent out its lovingly guarded favourite children as envoys, with the mission of making it known that even now, in this dull, barren time, life has not died out even in the most remote deserts. So I see and hear them once more in fancy, beautiful, timid, and full of the joy of life. It is thus their countless millions enliven the wastes of Africa, as well as the endless tundra marshes of Asia.

Deep, long-drawn-out notes, like those of musical glasses, ring in my ears. The brooding noonday heat is round me. The sun is in the zenith, and hardly another sound is to be heard all around. The wilderness lies before me in the hot glowing sunlight as if dead. My weary bearers have given themselves up to a dozing sleep, at the place where I have at last halted, after a march of many hours with a few companions.

Before me is a miniature mountain-world lighted up by the dazzling sunbeams. There is a mass of precipitous rocks, so characteristic of the Masai-Nyíka district, that stretches away into the distance. The Candelabra Euphorbias spread out their strange forms against the light, in grotesque clumps, and seem to me to make 
themselves one with the rocks, whose inorganic character and nature appear to be repeated in their characteristic forms.

From out of the midst of this stony wilderness these remarkable notes come sounding in my ears. They seem to be mysterious voices of rock and stone. The eye searching expectantly for the singer that is uttering this bell-like melodious music can discover nothing. And yet the notes come from the throat of a bird. It is once more some hornbills that are making their song of love and wooing resound in this wilderness. I have been able to listen to them for hours, losing myself in dreams, and I cannot say why I seemed to identify precisely these bird-voices with the voice of the African Sphinx, that legendary Sphinx which has sung already to so many, and lured many back again for ever. Thus may the songs and roices of the old sanctuaries of Northern Africa once have been. Again and again, when I heard it, I had to think of those men who, with burning longing in their hearts, went forth into the Dark Continent to wrest from it the secrets of its fauna. but had to pay for the undertaking with their lives.

A burning glow of sunshine, a dazzling light in overwhelming abundance over all the desert waste of rock-and amidst it, again and again, that deep, ghostly, metallic note, that directly impresses the traveller as though it were the language of the wilderness, peculiarly its own. But how can I describe all this in words?

And at a moment like this, as if to heighten the effect, over there the voice of the mightiest bird that the earth 


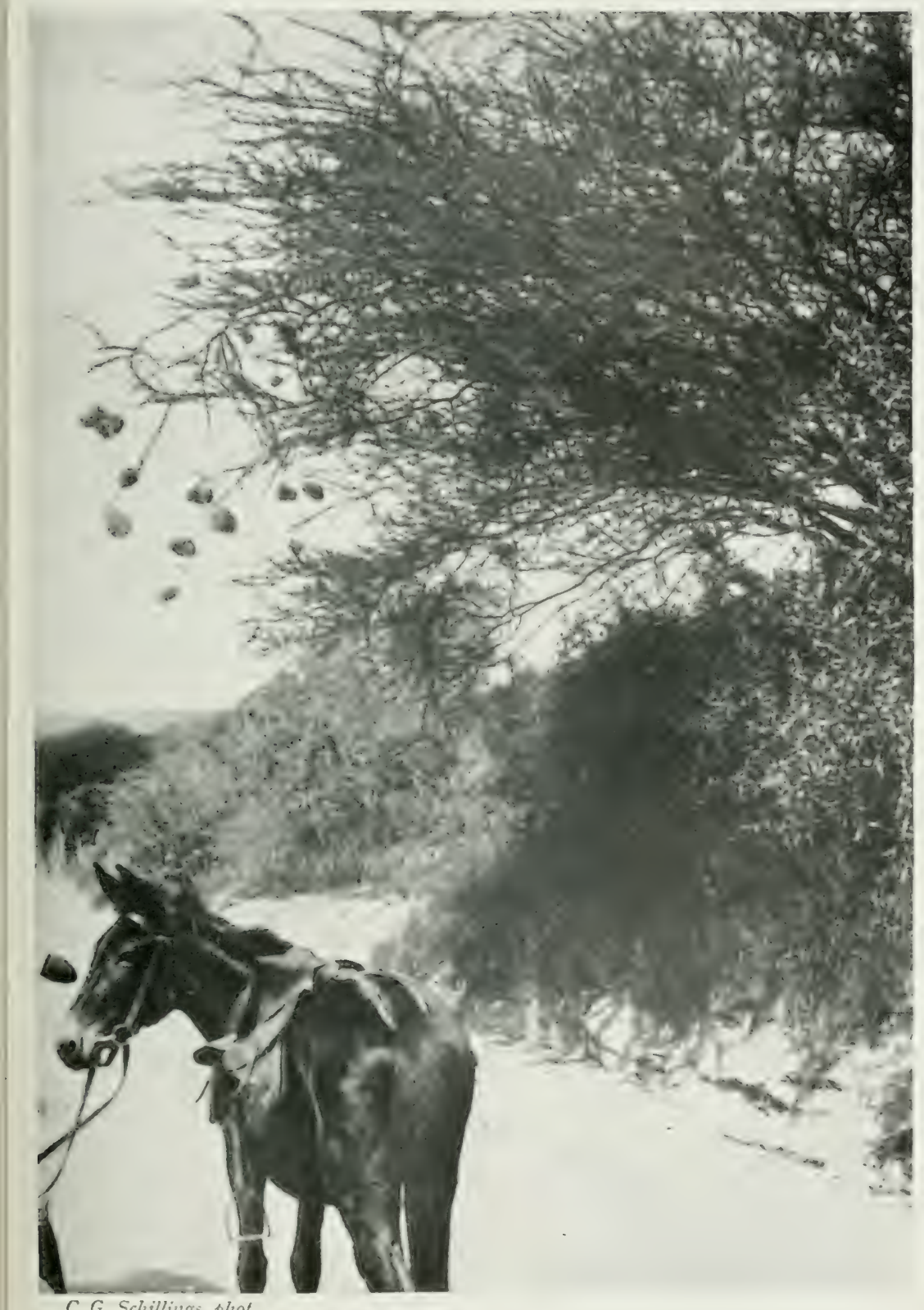

C. G. Schillings, pliot.

NESTS OF IVEAVER-BIRDS ON TIIE BOUGHS OF AX ACACIA. 

bears in this our day sounds forth. I hear in the distance the ringing cry of a hen-ostrich, and I listen to it with attention strained to the highest point.

The strange duet has now long died away. But it often comes up to me again in the midst of the movement of civilised life and takes me back on the wings of fancy to the glorious beauty of the wilderness.

But that uncouth tropical singer is not really needed to conjure up this frame of mind. A little unseen lark, all by itself, can evoke for me the charm of the solitudes of Nyíka as with a magic wand.

How this comes to pass, I will tell the reader. We must make a long tour. Now we are in the north, in our native country, in the midst of the spring, amongst the spreading fields of our German homeland. The song of the lark fills the air, and our heart expands to its music. We go out upon the open moor. We hear a trilling and quavering of another kind, with a strangely sweet touch of sadness in it, especially at night - the song of the woodlark. But now let the reader follow me to the little island of Heligoland. In the glare from the lighthouse, that sends afar its rays, - in this case rays that bring destruction,- - countless numbers of larks flutter and wheel about, bewildered in the darkness of the autumn night, and full of anxiety and fear. On a dark, rainy October night thousands of them fall victims to the death that lies waiting in ambush for them below this tower raised by the hand of man. Their little wings have brought them safe over the ocean to the small, island. But there one hears no rejoicing song. No! there 
resounds only something like an agonised cry for help from weak creatures in the direst peril of death.

Millions of larks fly thus each year southwarcis and northwards, obedient to that mysterious migratory impulse that guides them on their way.

The song of the lark and the cry of the lark are very different things. To those who know them they mean a song of happy springtime, and a cry for help in the night of death.

How comes it that I thus speak of, and have to think of, sounds uttered by the birds here at home? Simply because over there, in other lands, my fancy so often and so readily imagined the flying bird to be a messenger,-a courier for thoughts of home,-and connected such wishes and longings with its appearance and disappearance.

In autumn, the noblest of our northern songsters makes its way in a few clays and nights into the inmost heart of the Dark Continent. It disappears again in spring, to return to the north over velt and desert, morass, mountain and sea. The cuckoo, that only a few days ago could be scen in our northern lands by the eyes of men who knew how to recognise it, I see on the African velt, a wandering, flecting visitor. Thus it seems to bring me a greeting, like that brought by our oriole, our nightingale, and many other children of the homeland.

No one can be surprised that in these solitudes these birds, and their coming and going, are closely associated with our thoughts. It is the less to be wondered at secing that they are all such eloquent witnesses to the miracle that these weak creatures with their feeble wings 
twice each year traverse continents and fly safely over seas.

We cannot help thinking of the lark and its spring song at home, when in the wilds of Africa we hear its voice; and it appeals so impressively to the wanderer in the wilderness, that afterwards it has the power of bringing back by its music a picture of the Nyika in all its characteristic wildness. It is a song that has a character of its own. When I hear it, if it is in the Nyika, I cannot help thinking of the songster's frail, weak brethren of Europe, that, following an irresistible impulse, are perhaps at this moment meeting their death on the little island of Heligoland-obedient to the same instinct that sends myriads of their kind each year towards pole or equator. For even as the northern song of the lark awakens the soft, poetic spell of smiling fields, so, too, the mysterious and still deeply veiled spell of the Nyíka can find expression in its wonderful music.

Small, invisible almost, it rises in the air. Soon it is lost to sight in the sky. Then suddenly a song that, though so often heard before, is still a marvel, comes distinctly on the ear, its notes sharply accented and emphasised as if it were close to us. There is a sharp, rhythmical, clapping sound, as if small laths or pieces of whalebone were being rattled together. It comes from that tree right in front of us. No mistake about it seems possible. But the eye searches in vain for the producer of the sound.

Again and again one is deceived in this way. Who VOL. I 305 


\section{In Wildest Africa}

could imagine that that little bird far away over there, a hardly perceptible speck on the horizon, is producing this strange music? "Knáck! knáck! knáck!" again, and yet again, it comes to us ringing out loud and clear. Our little invisible songster does not tire of pouring out its strange misleading song. It is a kind of love-song of a species of lark, which was discovered by Fischer some fifteen years ago and bears the name of the naturalist, now long deceased; Mirafra fischeri, Rchw., is its scientific name. Its clapping and rattling are undoubtedly part of the charm of a journey in certain districts of the Masai-Nyíka.

Even in my tent, in the midst of the comparatively loud noise of the busy camp of my numerous caravan, I can hear the clapping, rattling voice of this lark. Some hundreds of yards away it flies up into the sky, like our own skylark, and hovers about clattering in the air, so loudly and distinctly that if I did not know its character and habits, I would have been continually looking for it close to my tent. It is very hard to quite free oneself from this illusion. One continually thinks that one hears the cry of the bird in one's immediate neighbourhood, the sound being produced much in the same way as that of the snipe.

And yet another strange voice of a lark resounds in my ears: a melancholy, plaintive, soft sound, till now unknown to me and to most others. All night long its calls and cries resound about my camp. I should never have thought that it was a lark (Mirafion

1 Cf. Professor Dr. A. Reichenow, Dic lïgel Afrikus. 
intercodens Rchw.) that thus made itself heard in the night, as our woodlarks do in moonlight nights at home. It was at the cost of much careful research that the discovery was made of what bird produced this song.

And the strange voice of yet another bird is inseparable from my recollections of the wilderness of East Africa. The xerophytic flora of the far-spreading thorny mimosa thickets gives shelter to a privileged member of the bird world, which is thus guarded in safety from all danger amid their thorny boughs and branches. I refer to a peculiar bird, belonging to the group of the Musophagidie, grey-feathered, green-beaked, long-tailed, and adorned with a crest. This strange fellow roves about restlessly-a bird about as big as a jay, misleading the traveller with his cry in the most curious way. Science calls him Chizaerhis lencogastra, Rüpp.; the German language has given him the name of "Lärmoogel" ("noisy bird").

And he has a perfect right to bear his name. There resounds somewhere near us, and in a way that completely deceives us, now the barking and snarling of a dog, now the bleating of sheep. Following the direction of the sound we look to see what produces it, and we find our bird hopping about nimbly upon the tops of the thorntrees and acacias, appearing to have no anxiety about the thorny spikes of the branches, in which he makes his home. With a cleverness that borders on the miraculous he makes his way amongst them, protected by them against the attacks of birds or beasts of prey, and in his 


\section{In Wildest Africa}

conscious reliance on the security of his dwelling-place, so to say, mocking at all enemies. So deceptive are his cries that at first, and especially when I was in the neighbourhood of native settlements, I was continually looking everywhere for sheep and their shepherds.

Many other typical bird-voices live in my memory. I hear the peculiar plaintive cry of the large cormorants that are busy with their fishing by the salt lakes of the wilderness. a cry that seems most fitted for these soliturles. The mysterious chattering and chirping of the little swamp-fowl come to my ear from the shallows and the bushes along the banks of silent rivers of the primeval forest, a bird-language so strange that the natives believe the birds are conversing with the fish in the stream. I hear the cackling of the knowing Nile-geese, that seem to be always engaged in conversation; when on the wing, too, a pair of them, in their affectionate fidelity, have always some warning, some reminder of something or other to call out to each other. Where their cry resounds one hears also frequently that of the wonderful, wailing peewit; it has a plaintive and melancholy effect on the mind of the listener. Far different is the noisy outcry of its brightly coloured cousin, a denizen of the thirsty wilderness (Stephaniby.x coronatus, Bodd.). Shrill and harsh the voice of the bird rings out, a watch-cry by day and night, and when in bright moonlight nights they tly in flocks over the camp. Swarms of these remarkable birds, the police of the wilderness in feathered uniforms, flutter around the traveller as he approaches. They ruin 3os 
his attempts to stalk wild animals, and their strident screeches, to which all other animals hearken, haunt him long after, as also the call and cry of the large, yelloweyed thick-knee, an inhabitant of the loneliest solitudes. But I cannot imagine the low shores of African lakes and the sea-coast without the cry of the wilely distributed

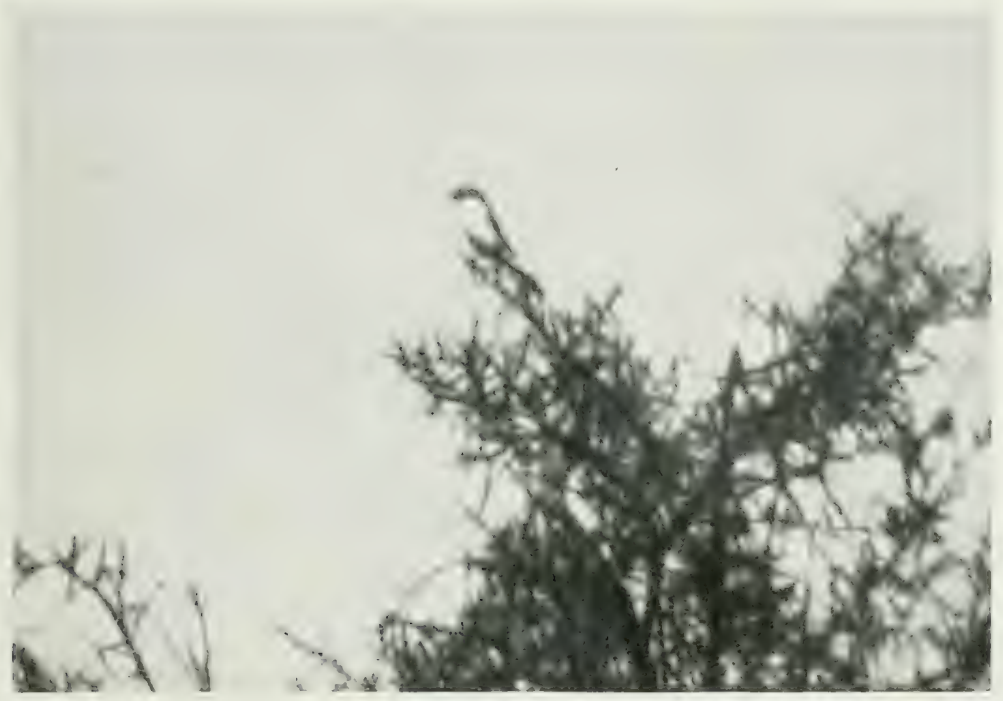

A SHRIKE (LANT'S CAUDATL'S Cab.) ON THE LOOK-OUT FROM THE HIGH BOUGHS OF AN ACACIA. ITS CRIES WHEN IT SEES A HUNTER ON THE MOVE OFTEN WARN THE ANIMALS HE IS STALKING.

sandpiper, which has its home in the far north. In winter its low plaintive cry is heard at every step: but even in summer the trained ear can distinguish it here and there. These individual stragglers from the north are thus to be found during all times of the year in this distant country, while the most of their kindred tribe have 


\section{In Wildest Africa}

successfully made their way to the Polar lands, their usual summer breeding-place.

High over my head the voice of the pretty avocet (Recurvirostra avocetta, L.), one of the most charming forms of the bird world known to us, transports me by magic to the distant and mournful lates of the Masailand wilderness. What the dwarf bustards (Otis gindiana, Oust.) keep calling out to each other with their continually repeated "Rágga-ga-rágga" is not to be discovered. But their cry, which has kept the fancy of the natives busy since olden days, is as inseparably associated with regions on which the grass grows high, as the voices and cries of the sandfowl, the francolins, and, above all, the jarring outcries of the guinea-fowl, on the velt. All the manifold voices of doves, cuckoos, parrots, hornbills, bee-eaters, shrikes, orioles, starlings, finches, weaverbirds, sylvians, and the rest, calling, exulting, rejoicing, uttering cries of alarm or complaint, have woven themselves into my recollections of happy days and days of toil.

Thus there still rings in my ear the triple note of the yellowish green bulbul (Pycnonotus layarti, Gurn.), which, like our sparrow, is present everywhere, till one almost tires of it. Most curious is the friendly play which the handsomely coloured glossy starling (Sprio superous, Ruipp.) carries on with a weaver-bird (Dincmollic dinemelli, [Hartl.] Ruipp) in flights like those of our sparrows. It comes back to me all the more vividly when I recall the notes uttered by these two birds, which, though such close friends and taking such delight in each other's 


\section{- The Voices of the Wilderness}

company, are so clistantly related. The curious warbling of the honey-finder (Indicator indicator, Gm.), which often guides the man who follows it to a wild bees' nest, also easily makes a permanent impression on the ear of the traveller.

And there are many other bird-voices that delight any one who takes pleasure in sound. When silvery moonbeams streamed over the camp, the night-jars (especially Caprimulgus fossei [Verr.] Hartl.) buzzed and hummed forth their strange song everywhere around. No matter how remote and desolate the wilderness in which the traveller laid down his head to rest, these goat-suckers were to be heard. Their voice makes a strong impression on us even in our own country in the lonely woods, but its effect is much more striking on the far-off equatorial velt. With noiseless soft beating of its wings the bird comes gliding past us; its wings almost touch us. When it pours forth its song, its monotonous sleepy song, I could listen to it for hours. In the daytime it starts up suddenly from the ground here and there in front of you, uttering the feeblest of cries, that it is impossible to represent. In the next instant it vanishes like some huge moth, and even the sharpest eye cannot distinguish it amongst the dry branches and leaves, or clinging close to the rocky ground. The song of the night-jar is among my most vivid recollections of the bird-voices of Africa.

In the neighbourhood of water, wherever it may be, and in the thick undergrowth, wherever the African wilderness extends, you hear the call and cry of a peculiar 
bird-voice. It rings out through the stillness with a deep double piping note, that impresses itself in a lasting way on the ear. It is the voice of the handsome organshrike (Laniarius athiopicus, Gm.). These shrikes, which mate permanently, always utter this note in such quick succession, one of the pair after the other, that at first you think you are listening to only a single bird. This beautiful bird-note indicates the proximity of water, and thus it has acquired quite a special significance in these countries.

Finally there is no sound from the throat of a bird that I call to mind so plainly, or so continually, as the song of the African nightingale (Erithacus africanus, [Fschr.] Rchw.). I have very frequently heard this beautiful song during the months of our winter, in many districts round Kilimanjaro. When I heard it unexpectedly for the first time, I was most deeply moved by it. Ten years ago I heard it during a day's march in the wooded gullies of the great volcanic mountain, and it was most clear and full and beautiful. I never expected thus to hear this northern bird-voice in the tropics. Later on, when I was camped at a consiclerable altitude in the primeval forests of Kilimanjaro, I was saluted with the cries of northern migratory birds, that, wheeling round the mountain, seemed to be flying over its everlasting snowfields. It was a strange coincidence in those Christmas days, the song of the northern nightingale, and those northern birds of passage on the wing under the equatorial sun! It is worth noting that this voice of the nightingale was the only genuine northern bird-song 
that I ever heard in Africa. That our nightingale also sometimes breeds there is indicated by the discovery of its nest by the late Dr. Fischer. But the problem of the extraordinary identity in character of this nightingale with its northern sister still awaits solution. Many difficult observations will have to be made in order to investigate it thoroughly.

What a contrast to this song of our northern nightingale is presented by the voices of the hyenas and jackals, the strange cry uttered by the leopard, all the sounds emitted by the antelopes, and finally the indescribably startling, harsh-sounding bellow of the crocodile!

But neither individually nor collectively can the effect of all these voices be expressed in words. They associate themselves with the forms of a flora untouched by the hand of man, and the unceasing throb of animal life. I think of them all together as a theatre of nature now flooded with sunlight, now in the mysterious darkness of night, or with glistening moonbeams playing over it. What impresses one so much is not merely these individual voices, but the way in which all the myriad voices mingle in one mighty chorus.

If this symphony of nature is to be written down, it must be by some master who will combine in one marvellous melody these musical utterances that are so mighty and impressive, so full of mystery and charm, and so often dying away in the deepest and most delicate cadences. None of these tones should be missing, no note of them all should be struck out. 


\section{In Wildest Africa}

I should like to set in contrast with this mighty primeral harmony of the wilderness the sounds and roices of the modern industrial world, which gradually and unwittingly we take to be something natural. He who would feel all its greatness and perfection must keep himself fitr awa! for weeks and months from the screaming whistle he hears on the railway and the howling siren of a steamship.

Then there is the insect world! Those flower-covered lushes have attracteal a multitule of areat droning bectles. They hasten to them in heary flight. On the ground a host of scarabrus beetles are busy with their special work. The ceaseless sharp chirps of the cicadas sing their continual song. Through all its variations there goes on this hum and buzz of the millions and millions of the lower creation. And joined with it there ring out the thousands and thousands of songs of the birds; the powerful voices of the great mammals bellow over 1)im and lushland, through swamps and primeval forests, over dale and hill. The concert of the feathered songsters is suddenly silent, as, it may be, the harsh cry of the leopard resounds, or the mighty, dull, rumbling roar of the king of the desert thunders over the earth; or the trumpet-like cry of the elephant vibrates through the woods; or harsh war-cries from human lips, battle-songs of primitive men, are heard-but heedless of it all, even at these moments, day and night resound the weak voices of all the myriads of lesser creatures of the animal world. But he who penetrates into this wilderness must have receptive senses to understand the full beauty of it all. 
- The Voices of the Wilderness

For him this harmony exists wherever the primitive animal world lives its life.

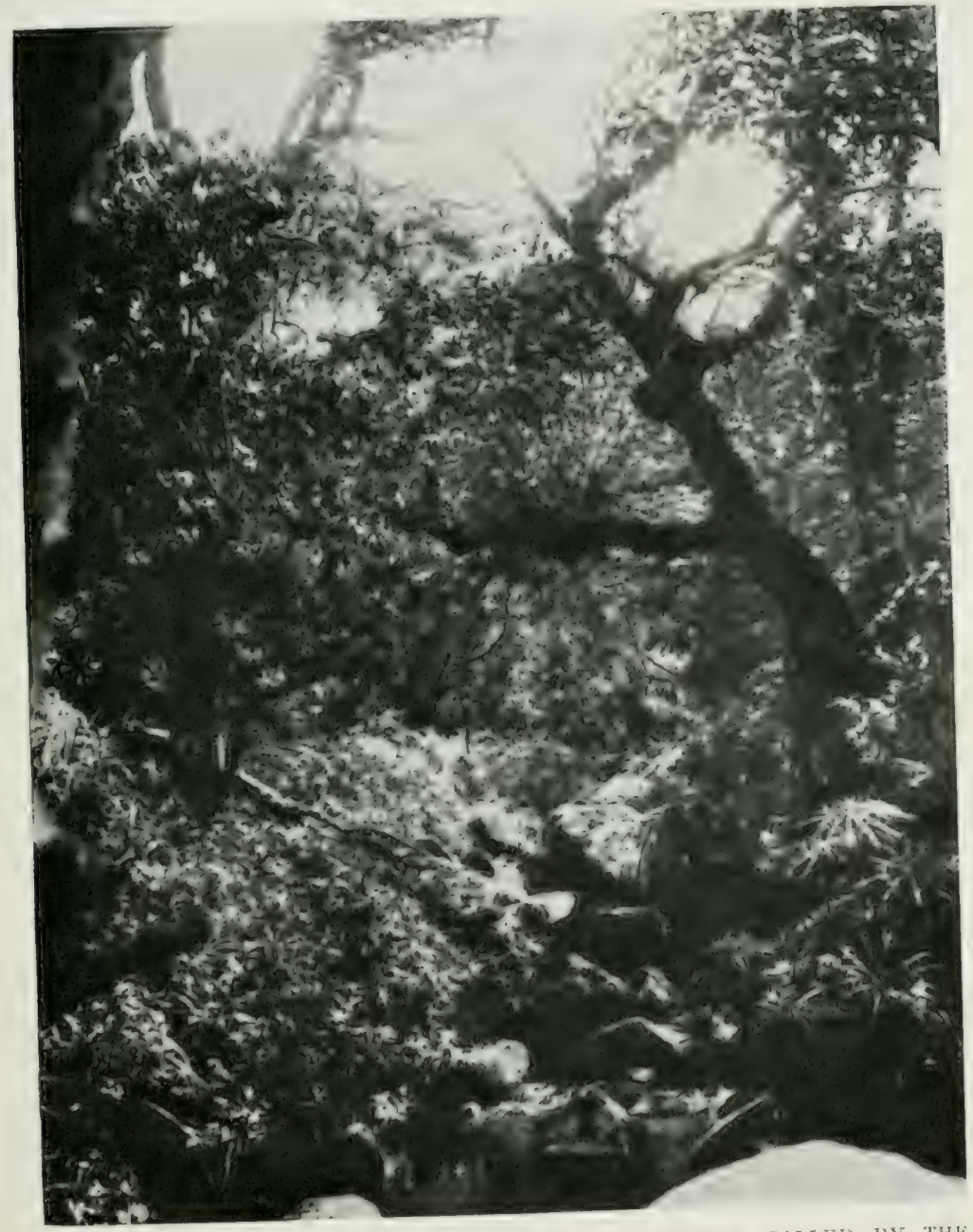

ON THE WEST SIDE OF RILIMANJARO I FOUND A IBROOK, CALITI) 13Y TII MASAI "MOLOGH," ABOUT TIN MULE FROM TIE WESTERN 'NJIR SWAMPS IN THE DRY SEASON IT SUDDENLY DISADPEARS AMONG THI STONES AND REACHES THE SIVAML'S BY AN UNDERGROUND CIIANNEI. 
Glorious and grand, too, is the language of Nature when she herself raises her primeval voice, associated with no sound of life that we can perceive. Thus it is in the hours of storm by night, when on the plain, or in the primeval forest, or on the hill slopes, the thunder roars round the little camp, and the crackling lightning comes down in zig-zags. Then the rumbling thunder, the rushing downpour of the water-floods, the roar of the storm-wind, speak with an impressiveness that is beyond all description. Then in their hour of death the giants of the primeval forest, the mighty, venerable trees, suddenly themselves find a voice that strikes loudly on the ear: they groan in the embrace of the wind, and under its fury crash thundering to the ground. Then, when the earth and the rocks under our feet seem to shake, when the powers of Nature are let loose in all their might, when weak little man in his small tent, alone in the midst of all this violence, listens to the sounds, alone and abandoned like the sailor on a frail plank in the midst of a raging ocean, then it is that the wilderness sings its greatest, noblest, most wonderful song.

The traveller may yet return to the African wilderness and hear once more the voices of the smaller denizens of the wild. The chirping of cicadas will lull him to rest, or the buzzing of the mosquitoes forbid it. Their chirping and buzzing will bear witness that these waves of life roll on untroubled and uninjured by the incoming of civilisation. But the greater voices will become rarer and rarer. Soon the trumpeting of the elephant, the roar of the lion, the bellow of the hippopotamus will be heard no longer. 
But to-day one can still hear all these sounds which I have described, and which our most remote ancestors listened to all day and all night in the ages when there still lived in Europe a fauna very similar to that which we find dying out in East Africa. By day and night they go forth in trees and thickets, by swamp and reed-bed. The song of birds is accompanied by the monotonous deafening chorus of the bullfrogs. Even in the traveller's tent the crickets chirp, and the nightjar buzzes and buzzes past it, and tells and whispers of the nightly life and movement of the animal world, in its monotonous mysterious song.

A jackal holds a conversation with the evening star. In the dark night the deep bass of the hyena is heard; and then it laughs aloud, in a weird, shrill, shrieking treble. This laugh, seldom uttered, but when heard making one's heart shudder, is not a thing to forget; on feverish nights it plagues one still in memory. No one need jest about it who has not himself heard it. He who has heard it understands how the Arabs take the hyenas to be wicked men living under a spell.

Now at last the lion raises his commanding voice, and one thing only is wanting to the whole nocturnal spellthe noisy trampling of timid and harassed droves of zebras and other herds of wild things. But if the ground of the velt, hardened by the burning sun, rings once more to the thundering hoof-beats of the zebras, the eye fails in the darkness, and only our ears perceive by their numberless sounds the waves of life that are surging around us; and then indeed the listener comes to full 


\section{In Wildest Africa}

consciousness of how rich the animal-language of the Nyília still is. . . Nowhere else in the world of to-day do all the voices of the wild resound more. impressively, and for him who listens to this language there is no escape from that mysterious spell-the Spell of the Elelescho! 


- 



\section{PLEASE DO NOT REMOVE CARDS OR SLIPS FROM THIS POCKET \\ UNIVERSITY OF TORONTO LIBRARY}

Bioled 
